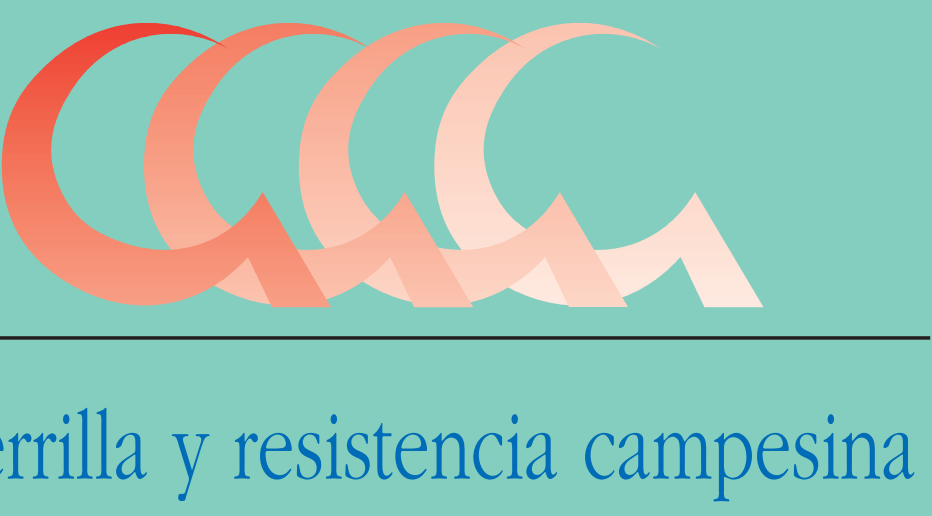

Guerrilla y resistencia campesina

La resistencia armada contra el franquismo en Aragón (1939-1952)

Mercedes Yusta Rodrigo



Prensas Universitarias de Zaragoza 

GUERRILLA Y RESISTENCIA CAMPESINA

$L$ a resistencia armada

contra el franquismo en Aragón

(1939-1952) 



\section{GUERRILLA Y RESISTENCIA CAMPESINA $L$ a resistencia armada contra el franquismo en Aragón (1939-1952)}

Mercedes Yusta Rodrigo 


\section{FICHA CATALOGRÁFICA}

\section{YUSTA RODRIGO, Mercedes}

Guerrilla y resistencia campesina : la resistencia armada contra el franquismo en Aragón (1939-1952) / Mercedes Yusta Rodrigo. — Zaragoza : Prensas Universitarias de Zaragoza, 2003

XI, 292 p. ; $22 \mathrm{~cm}$. - (Ciencias Sociales ; 49)

\section{ISBN 84-7733-630-X}

1. Guerrilleros-Aragón-1939-1952. 2. Aragón-Historia-1939-1952. I. Prensas Universitarias de Zaragoza. II. Título. III. Serie: Ciencias Sociales (Prensas Universitarias de Zaragoza) ; 49

$$
\begin{aligned}
& 355.425 .4(460.22) \ll 1939 / 52 » \\
& 94(460.22) \ll 1939 / 52 »
\end{aligned}
$$

No está permitida la reproducción total o parcial de este libro, ni su tratamiento informático, ni la transmisión de ninguna forma o por cualquier medio, ya sea electrónico, mecánico, por fotocopia, por registro u otros métodos, ni su préstamo, alquiler o cualquier forma de cesión de uso del ejemplar, sin el permiso previo y por escrito de los titulares del Copyright.

(C) Mercedes Yusta Rodrigo

(C) De la presente edición, Prensas Universitarias de Zaragoza

1. a edición, 2003

Ilustración de la cubierta: José Luis Cano

Colección Ciencias Sociales, n. ${ }^{\circ} 49$

Director de la colección: José Manuel Latorre Ciria

Editado por Prensas Universitarias de Zaragoza

Edificio de Ciencias Geológicas

C/ Pedro Cerbuna, 12

50009 Zaragoza, España

Prensas Universitarias de Zaragoza es la editorial de la Universidad de Zaragoza, que edita e imprime libros desde su fundación en 1542.

Impreso en España

Imprime: Sdad. Coop. de Artes Gráficas Librería General

D.L.: Z-751-2003 


\section{PRÓLOGO}

Es tarea más ardua honrar la memoria de los seres anónimos que la de las personas célebres. La construcción histórica está consagrada a la memoria de los que no tienen nombre.

(W. Benjamin, 1940)

Tanto la memoria como el olvido, que es la cara oculta de la luna de la memoria, se construyen socialmente $y$, además, son objeto, ni siquiera oscuro, sino bastante claro, de deseo politico, pues al poder, a los poderes, les ha atraido e interesado gestionar, controlar, administrar los recuerdos de las gentes, esa memoria individual, de grupo, social, generada por la historia personal y colectiva. El poder politico siempre ha practicado una compleja política de la memoria que combina contradictoriamente invención y olvido del pasado, en diversas dosis y de diferentes maneras, según las cambiantes necesidades de cada momento y situación. La propuesta de Benjamin es radicalmente democrática, y ése es el sentido que tiene el hecho de que hayan sido precisamente las palabras arriba recordadas las que han merecido quedar esculpidas, recortadas contra el acantilado, en el monumento que enlaza su tumba y el mar de Port-Bou.

También suele suceder, al margen de la propensión que el poder tiene siempre a gestionar memorias y recuerdos, que muchas experiencias históricas colectivas, al igual que tantos episodios de las biografias personales, pasen por una etapa, más o menos larga, de olvido, tanto más cuanto más conflictivas hayan sido para sus protagonistas, hasta que, en el mejor de los casos, comiencen a ser reconstruidas. En Alemania, en las dos Alemanias de la posguerra, fue administrada una larga etapa de olvido del pasado nazi, colectivo e individual: la sociedad y los estados, los individuos y los historiadores coincidieron en la terapia del olvido, hasta que a partir de los años ochenta comenzaron a fluir, con intensidad y entre polémicas, tanto la historia como la memoria del 
pasado reciente. También en Francia se habia olvidado la envergadura real del colaboracionismo con el nazismo y con Vichy, pues en la memoria oficial, construida al alimón entre De Gaulle y el Partido Comunista, lo único visible durante mucho tiempo fue la resistencia antinazi, y hubo que esperar a los años noventa para que comenzara a desplegarse una avalancha historiográfica y editorial sobre tantos pasados ocultados, colectivos y personales.

En España los vencedores manipularon e instrumentalizaron la historia y la memoria de la guerra de modo tan excluyente y vengativo como lo fue en la práctica su politica durante cuatro décadas, y con formas tan contundentes y masivas que todavia quedan, por calles, plazas e iglesias, numerosos testimonios de la particular política de la memoria que desarrolló el franquismo, antes de que las necesidades de la transición politica aconsejaran congelar todavía un tiempo los recuerdos de los vencidos. Así que sólo desde la última década del siglo pasado tanto historiadores como protagonistas y portadores de memorias silenciadas van reconstruyendo historias escondidas y pasados eclipsados.

Las sociedades, y también sus historiadores, experimentan, pues, fases de olvido terapéutico (visibles hoy en los paises del antiguo bloque soviético), y lo mismo y a la vez les sucede a los individuos que las componen. En 1937 el Gobierno Vasco organizó el éxodo a varios países europeos de unos treinta mil niños vascos, refugiados que acabaron retornando en su mayor parte, una gente que no habló, no recordó públicamente, hasta los años ochenta; ahora hay asociaciones, congresos y tesis doctorales sobre esta experiencia compartida, y se puede evaluar la magnitud del silencio y el olvido cuando se conoce que un niño vasco retornado de Francia no sabia que "mi mujer habia estado en Inglaterra hasta mucho más tarde de casarnos, no sabia..."; la gente callaba, en la misma medida en que eran callados.

Jorge Semprún, en La escritura o la vida, testimonia que al salir del campo de concentración de Buchenwald "escogi el olvido, para salvar mi propia identidad fundamentada en el horror dispuse la estrategia de la amnesia voluntaria", hasta que en 1995 escribió el libro para reflotar esa parte reprimida de su memoria. También Primo Levi tardó veinte años en publicar La tregua, con su experiencia de los Läger. El judio vienés Jean Améry, que acabará suicidándose como Levi, publicó su tremendo testimonio sobre Auschwitz en 1966 (Más allá de la culpa y la expiación). Y sin ir tan lejos, cuando el altoaragonés Mariano Constante comienza a escribir y difundir sus experiencias, en 1971, han pasado veinticinco años desde su salida del campo de con- 
centración de Mauthausen; él mismo cuenta que fueron dos amigos franceses los que le animaron en 1967 a relatar por escrito sus recuerdos, y, aunque no los menciona, quienes le empujaban a escribir eran Arthur London, el comunista checo que estaba recordando por las mismas fechas en La confesión (1968) el proceso estalinista al que habia sido sometido, hacia veinte años, y su mujer Lise London, quien, por su parte, nos ha dejado recientemente en dos tomos su memoria personal.

En España, como en otras partes, los historiadores han actuado y actúan como adelantados en la recuperación de pasados prohibidos, negados u olvidados: en los años noventa abundaron las investigaciones sobre la represión franquista durante la guerra civil y la inmediata posguerra, hasta que en 1999 se publicó Víctimas de la guerra, la sintesis que mejor ha trasladado los resultados de la investigación histórica al conocimiento de la opinión pública. Pues la sociedad también necesita conocer aquellos aspectos que habia olvidado, o que le habian hecho olvidar, de modo que, en un proceso que se alimenta mutuamente, se multiplican tanto las demandas y proyectos editoriales, o de otros medios de comunicación, como las investigaciones históricas sobre temas que ahora mismo, en forma de libros, compiten en los escaparates de las librerias: represión, maquis y resistencia, trabajo forzado en batallones disciplinarios, campos de concentración franquistas - un rosario de 34 campos en 1939-, titulos más periodísticos como Los esclavos españoles de Hitler, Toda España era una cárcel, etc.

Este libro de Mercedes Yusta es la versión de su tesis doctoral, defendida en el otoño del año 2000 con el título de La resistencia armada contra el régimen de Franco en Aragón (1940-1952). No es, ciertamente, la primera investigación que aborda el tema de los varios miles de guerrilleros organizados en el maquis, pero si que es —como reconocen las recientes sintesis que sobre asunto, tan desconocido hasta hace poco como espectacular, han promovido editoriales de prestigio - la investigación más solvente desde el punto de vista profesional y académico con la que cuenta hasta ahora la historiografía española. Las investigaciones de la autora sobre el tema en Aragón han dejado sentado un método; sus informaciones e interpretaciones están necesariamente recogidas en los libros que en el año 2001 han publicado Secundino Serrano (Maquis, Madrid, Temas de Hoy) y Francisco Moreno (La resistencia armada contra Franco, Barcelona, Critica), autores que tuvieron acceso a la tesis doctoral de la investigadora zaragozana; su concepción de la guerrilla antifranquista como un capitulo más de la resistencia antifascista en Europa explica el interés que 
sus investigaciones y publicaciones han despertado en universidades y medios académicos de Francia, donde Mercedes Yusta profesa en la actualidad como maître de conférences en el Institut d'Études Politiques de París, asi como su participación e integración en equipos de investigación en la Universidad de París VIII, dirigidos por la reconocida hispanista Danièle Bussy Genevois, quien también cotuteló la tesis doctoral que está en el origen de este libro.

Las aportaciones de Mercedes Yusta son conocidas, pues, en los medios académicos españoles y franceses en los que prosigue sus investigaciones, a la vez que alimentan las sintesis generales que ofrece el mercado editorial, e incluso una cinematografía reciente de notable impacto a la hora de recordar a la sociedad la existencia de la guerrilla contra el franquismo: su asesoramiento histórico para la película Silencio roto pudo tener algo que ver con la perspectiva de las mujeres guerrilleras que introdujo Armendáriz en su relato, como demuestra la relevancia que les ha otorgado la autora de este libro en el proceso y en los resultados de su investigación.

$Y$ es que la investigación histórica, al igual que sucede con el bosque, no se improvisa. Merche se formó como historiadora a finales de los años noventa, cuando elaboraba su memoria de licenciatura sobre la actividad del maquis en el Maestrazgo turolense, sumergida en papeles de archivos, sorprendida por los relatos que oía, a caballo entre la historia, el recuerdo real y la memoria mítica, un libro que publicó la Institución Fernando el Católico en 1999 con el título de La guerra de los vencidos. El maquis en el Maestrazgo turolense, 19401950 y que, de modo bastante insólito en una colección institucional, va por su cuarta edición, lo cual nos indica la existencia de una demanda real de conocimiento del pasado, de reivindicación de sus protagonistas y testigos, al igual que nos dice algo sobre la función que el conocimiento histórico del pasado reciente tiene a la hora de agitar, movilizar u organizar la memoria personal y colectiva, y nos habla, en definitiva, de las relaciones entre historia y memoria.

Guerrilla y resistencia campesina. La resistencia armada contra el franquismo en Aragón (1939-1952) es una reconstrucción cuidadosa de las actividades de la guerrilla antifranquista en el conjunto del territorio aragonés; completa, desde la perspectiva de la oposición armada, el buen conocimiento que se tiene en Aragón tanto de la represión franquista a partir del verano de 1936 como del funcionamiento político e institucional del régimen en sus primeros tiempos. Pero sobre otros méritos, la principal característica del libro es la habilidad y eficacia con que Mercedes Yusta complementa su oficio 
de historiadora con la memoria de los protagonistas y con la huella que esa memoria ha dejado en muchos ciudadanos aragoneses; combina historia $y$ memoria de modo que el análisis histórico sale beneficiado al recoger, contrastar, verificar y completar esa memoria recabada en unos cuarenta testimonios orales, al igual que la propia memoria de los protagonistas queda más y mejor estimulada, reavivada, organizada, reivindicada, oficiando la investigadora como un médium entre la memoria y la historia.

Memoria e historia no son lo mismo, pues la memoria no es el pasado sino lo que se recuerda del pasado, pero de lo que se trata precisamente es de reconciliar historiografía y memoria, porque los recuerdos están destinados a desaparecer con sus testigos y sólo la historia, la que reclamaba la radical voluntad emancipatoria de Benjamin, puede salvar del olvido a sus vencidos, redimiéndolos de haberse pensado y de haber vivido como vencidos. Un indice de artículos de ciencias sociales publicados entre 1996 y 1999 encuentra 634 títulos que recogen la existencia dentro de un mismo titulo de los descriptores "historia» $y$ «memoria». El sociólogo francés Maurice Halbwachs, quien acuñó el concepto clave de memoria colectiva y fundó en 1925 la sociología de la memoria, fue a morir de disentería, años más tarde, en el campo de concentración de Buchenwald en los brazos de un antiguo alumno, Jorge Semprún, quien intentaba confortarlo en su agonia leyéndole versos de Baudelaire.

Un poder democráticamente legitimado ha de ir acompañado de una historia, no menos democratizada, en la que no haya agujeros negros y en la que quepan todas las memorias, especialmente las silenciadas y condenadas al olvido por cualquier clase de vencedores, y esa historia debe seguir las advertencias de Benjamin para salvar del olvido a los vencidos, para salvarse del olvido él mismo — su propia obra y memoria —, mensajero y primera victima de Auschwitz con su suicidio en la España de Franco contra el aliento de la Gestapo, y a quienes como él se vieron y se iban a ver derrotados y vencidos en el terrible año de 1940 y en los siguientes. Pero al fuerte y justificado pesimismo de Walter Benjamin nunca le faltó la esperanza en un horizonte emancipatorio, y para él eran los historiadores los que habian de tener el don de atizar en el pasado la llama de la esperanza, convencidos de que "si el enemigo vence ni siquiera los muertos están seguros». Los maquis, los muertos y los vivos, están hoy más seguros en la historia y en la memoria de todos. 



\section{AGRADECIMIENTOS}

En un trabajo de estas características, cuya elaboración ha requerido varios años y la colaboración de numerosas personas, el capítulo de agradecimientos ha de ser necesariamente muy largo. Sin esta colaboración, en una investigación condicionada por el arduo acceso a la documentación y en la que las fuentes orales ocupan un lugar destacado, hubiera sido muy difícil llevar a buen término esta empresa. Agradezco en primer lugar al director de esta investigación, el doctor Carlos Forcadell Álvarez, su apoyo y excelente magisterio a lo largo de estos años, a los se debe en parte esencial el resultado de este trabajo. Mi agradecimiento también a Danièle Bussy Genevois, que aceptó codirigir la investigación y guiarme por las intrincadas sendas de universidades y bibliotecas francesas. También es grande mi gratitud hacia mis compañeros del departamento de Historia Moderna y Contemporánea de la Universidad de Zaragoza, en especial a Alberto Sabio, que leyó y comentó algunos de los capítulos de esta investigación. Y a quienes, como José Giménez Corbatón, Cristina Yusta, David Corellano, Anabel Bonsón, Irene Abad, José Antonio Angulo o Juan Gavasa me han ayudado en la localización de informantes y han compartido conmigo la experiencia de la entrevista. Doy las gracias a Quico y Odette Martínez por su colaboración y su amistad. A Sixto Agudo, Ángel Fernández, Eutimio Martín, Jesús de Cos, Irène Tenèze, Fernando Martínez Baños y Enrique Líster López, que me han permitido, generosamente, el acceso a archivos, testimonios y documentos. A Guillermo Fatás, por su amistad y sus siempre atinados consejos. A Nelo Martí, por su fe inquebrantable y contagiosa. A Secundino Serrano, con quien tengo una gran deuda intelectual. A Esperanza, Manolo, Reme y Florián, que me han dado mucho más que su testimonio acerca del tiempo amargo que les tocó vivir. Y, muy especialmente, a todos los y las infor- 
mantes que han accedido amablemente a compartir conmigo sus recuerdos, y sin los cuales este trabajo no hubiera sido posible. La presente investigación fue financiada por una beca FPU del Ministerio de Educación, Cultura y Deporte, y fue defendida para obtener el grado de doctora en septiembre de 2000 ante un tribunal formado por los profesores Juan José Carreras, Francesc Bonamusa, Gérard Brey, Julián Casanova y Dolores Ramos, que acordó por unanimidad concederle la máxima calificación. A todos ellos les agradezco sus interesantes sugerencias, que he recogido en la redacción final de la obra.

Dedico este libro, cuya elaboración ha ocupado varios años de mi vida, a mis seres más queridos: a Javier, a mis hermanos Cristina y Miguel Ángel y a mis padres. 


\section{INTRODUCCIÓN: UN CRUCE DE CAMINOS ENTRE LA HISTORIA Y LA MEMORIA}

La historia de la España de los años cuarenta da en ocasiones la impresión de ser una historia inmóvil, casi braudeliana. Tras la tremenda convulsión de la guerra civil se diría que sobre España se abate una paz de cementerio. Los años cuarenta son descritos como un tiempo de silencio, ${ }^{1}$ de temor, años mudos en los cuales el milagro de haber sobrevivido, de seguir sobreviviendo, anulaba cualquier tipo de acción que fuera más allá de apuntalar esa supervivencia, de reconstruir un país exhausto. Para los que habían apoyado la sublevación militar continuaba la tarea, ya comenzada durante la guerra civil, de sentar las bases de un "Nuevo Estado». ${ }^{2}$ A los vencidos que no pudieron o no quisieron emprender el camino del exilio les esperaba un largo calvario de depuraciones, cárceles y paredones. Y para la mayoría se abría una triste etapa de hambre, de autarquía y de silencio. Entre el fin de la guerra y los primeros síntomas de protesta colectiva, cuya fecha fundacional se suele hacer corresponder con la huelga general de Barcelona en marzo de 1951, doce años de silencio y de inmo-

1 Así se titulan tanto la conocida novela de Luis Martín Santos como el libro de Michael Richards, en el cual describe ese ambiente opresivo, de represión y autarquía, propio de la larga posguerra española. Ver Michael Richards, Un tiempo de silencio. La guerra civil y la cultura de la represión en la España de Franco, 1936-1945. Crítica, Barcelona, 1999.

2 Este proceso es minuciosamente descrito para la región aragonesa por Ángela Cenarro en su libro Cruzados y camisas azules. Los orígenes del franquismo en Aragón, 19361945. Prensas Universitarias de Zaragoza, Zaragoza, 1997. 
vilidad. La brutalidad de la represión de la inmediata posguerra no parecía dejar otra alternativa.

Y sin embargo, la había. El final oficial de la guerra no supuso el fin de las hostilidades, y en toda la geografía española se siguió combatiendo durante la década de los años cuarenta. En las montañas de León, de Galicia, de Asturias, de Andalucía, de Aragón, grupos de guerrilleros emprendieron una lucha soterrada contra el régimen fascista, poniendo en pie un complejo movimiento de resistencia que estaba en consonancia con otros movimientos antifascistas del resto de Europa.

En las regiones españolas que cayeron inmediatamente en manos de los sublevados, la guerrilla se formó tomando como base los grupos de «huidos» izquierdistas que escaparon fuera de los núcleos de población, a las montañas, de una represión que se presentía casi tan feroz como posteriormente resultó ser. Así ocurrió en León, Andalucía o Galicia. En Aragón, sin embargo, la génesis de la guerrilla tiene un origen diferente: el fenómeno de los «huidos» no fue apenas relevante y el movimiento guerrillero apareció a partir de una infiltración masiva de guerrilleros que se produjo en octubre de 1944 y ha pasado a la historia con el nombre de «invasiones del valle de Arán». A partir de esta fecha, la resistencia armada en Aragón fue organizada por el Partido Comunista de España desde el exilio, aunque la participación en este movimiento tuvo un signo político plural. Y uno de los objetivos de este estudio consiste en desentrañar y explicar esa pluralidad.

Los interrogantes que surgen a la hora de plantearse los objetivos por alcanzar mediante el estudio de la resistencia armada en Aragón son numerosos y de muy variada naturaleza. El estudioso o estudiosa que se introduce en este nebuloso terreno se encuentra frente a unos hechos escasamente documentados, en los que el mito y la leyenda han hecho fácil presa. Y se encuentra, sobre todo, con diferentes niveles de realidad que es necesario interpretar. Bajo ese estrato casi inmóvil de doce años en los que se diría que no ocurrió nada o casi nada, en los que sobrevivir parecía (era, probablemente) la tarea más inmediata, bulle la vivencia de una población atemorizada que veía instalarse en el poder un régimen represivo y excluyente, y que era testigo de la reapertura de conflictos que el fin de la guerra civil no había cerrado ni mucho menos. Tras las páginas conciliadoras de la prensa oficial, controlada por una férrea censura, los informes de las 
autoridades, la prensa y la propaganda clandestinas y la voz de los protagonistas y testigos describen un panorama de enfrentamiento y conflictividad, una de cuyas manifestaciones, la más visible, la que más preocupó a las autoridades, fue la guerrilla. Ésta tuvo como principal escenario las zonas rurales, excepto en Madrid y en Cataluña, donde la lucha armada se desarrolló también en las ciudades. En Barcelona, la guerrilla anarquista tomó la forma de una guerrilla urbana, aunque conectada también con el mundo rural en el que numerosos pageses se convirtieron en sostenedores de la lucha armada, como muchos campesinos del resto de zonas guerrilleras de España. ${ }^{3}$

El presente estudio ha debido enfrentarse, en primer lugar, a la dificultad de documentar unos hechos que adoptan una magnitud muy diferente según la perspectiva adoptada. Para las fuerzas represoras, que, de paso, fueron las primeras en publicar estudios acerca de este fenómeno, se trataba de un intento desesperado de desestabilización por parte de grupos considerados más como bandas de malhechores que como auténticos oponentes políticos. Para los protagonistas, los guerrilleros, su lucha era una auténtica guerra contra el régimen, con visos de éxito. Y los testigos — que también fueron protagonistas-, la población rural, se debaten entre la perplejidad, la admiración, el rechazo y, sobre todo, el miedo.

La visión de las fuerzas del orden encargadas de la represión de la guerrilla fue, como decimos, la primera en ver la luz, aún en vida del dictador. Nos referimos a textos como los de Tomás Cossías (antiguo agente de la Brigada Político-Social, destinado a la zona de Levante) o Francisco Aguado Sánchez, coronel de la Guardia Civil retirado. La imagen que transmiten es, como se ha indicado, la de la lucha abnegada de las fuerzas del orden contra unos bandoleros despiadados. Al otro lado de la frontera se elaboraba, por el contrario, la leyenda «blanca» del maquis, una historia heroica y mitificada de la guerrilla del interior y sus protagonistas, haciendo hincapié, sobre todo, en el papel representado por el PCE, el principal organizador de la guerrilla del interior, pero no el único. Sus autores eran, en su mayoría, personas directamente vinculadas con la oposición antifranquista

3 Para la guerrilla anarquista, ver las obras de Antonio Téllez, Sabaté. Guerrilla urbana en España (1945-1960). Plaza y Janés, Barcelona, 1978, y La guerrilla urbana en España: Facerías. Ruedo Ibérico, París, 1974. 
o con el propio PCE. ${ }^{4}$ A partir de la muerte del dictador y, sobre todo, de la normalización democrática de la vida del país tras el fallido golpe de Estado de 1981, se produjo un segundo momento historiográfico en el estudio de la guerrilla, en el cual vieron la luz monografías de carácter regional, fruto en su mayoría de trabajos académicos y elaborados por profesionales de la Historia, que tienen un carácter más objetivo y menos propagandístico que algunas de las obras anteriores. En Aragón, las obras existentes siguen estos hitos; en mayo de 1977, con una democracia recién estrenada y aún balbuceante, apareció en el periódico Andalán una serie de artículos con el título «El maquis en Aragón», firmados por Eloy Fernández Clemente. En 1987 Fernanda Romeu publicó su monografía sobre la Agrupación Guerrillera de Levante y Aragón. Y un año después apareció el trabajo de Paloma Fernández Pancorbo, El maquis al norte del Ebro. Y en este momento vivimos una tercera etapa de florecimiento de estudios acerca de este tema, con la reciente aparición de varias monografías y obras literarias que tienen como protagonistas a los guerrilleros antifranquistas. ${ }^{5}$

4 Tomás Cossías, La lucha contra el maquis en España. Editora Nacional, Madrid, 1956; Francisco Aguado Sánchez, El maquis en España. Librería Editorial San Martín, Madrid, 1975. En cuanto a las obras de tono "épico», algunas de las cuales fueron escritas por participantes en el movimiento guerrillero, citaremos, sin ánimo de exhaustividad, a A.E. Fernández, La España de los maquis. Era, Méjico, 1977; Andrés Sorel, Búsqueda, reconstrucción e historia de la guerrilla española del siglo XX a través de sus documentos, relatos y protagonistas. Librairie du Globe, París, 1970; José Gros, Abriendo camino. Relato de un guerrillero comunista. Prólogo de Dolores Ibárruri. Librairie du globe, París, 1971; Carlos J. Kaiser, La guerrilla antifranquista. Historia del maquis. Ed. 99, Madrid, 1976; Eduardo Pons Prades, Guerrillas españolas. 1936-1960. Planeta, Barcelona, 1977 (obra que se ha convertido en referencia imprescindible por la ingente aportación de datos y su labor de identificación de los individuos que lucharon en la guerrilla y las acciones en las que participaron, a pesar de que, debido a la preeminencia de las fuentes orales sobre las escritas, incurre en varios errores. Es interesante también por ser una de las pocas escritas desde la óptica anarquista); J.A. Vidal Sales, Después del 39. La guerrilla antifranquista. ATE, Barcelona, 1976; y Rafael Gómez Parra, La guerrilla antifranquista, 1945-1949. Revolución, Madrid, 1983 (obra que, a pesar de su fecha tardía, sigue la línea oficialista y mitificadora propia de la literatura generada por el PCE en el exilio).

5 Además de las obras de carácter académico, a partir de mediados de los ochenta aparecen numerosas obras de tipo memorialístico o biográfico, escritas por los protagonistas, personas cercanas a ellos o periodistas. En lo que se refiere a los estudios académicos, destacaremos para la guerrilla en Aragón: Eloy Fernández Clemente, «El maquis en Aragón", Andalán, n. ${ }^{\circ}$ 112, 113 y 114, mayo de 1977; Fernanda Romeu, Más allá de la utopia: la Agrupación Guerrillera de Levante. Alfons el Magnànim, Valencia, 1987; Paloma Fernández Pancorbo, El maquis al norte del Ebro. DGA, Zaragoza, 1988. Recientemente ha aparecido la primera obra de síntesis, la de Secundino Serrano, Maquis. Historia de la guerrilla antifranquista. Temas de Hoy, Madrid, 2001, que, por primera vez, analiza el fenómeno de la guerrilla en el ámbito estatal. 
Sin embargo, la resistencia armada no es sino una de las facetas, la más «visible», de la resistencia de un importante sector de la población (los vencidos, los «rojos») a la imposición final de un régimen contra el que se luchó enconadamente durante tres años. La lenta y penosa reconstrucción de las organizaciones políticas de izquierdas (de algunas de ellas) y otros signos menores de descontento frente al régimen, como los delitos de carácter económico, la transgresión de ciertas leyes de nuevo cuño o la resistencia a encuadrarse en las organizaciones del régimen (lo que conocemos como "resistencia pasiva», tan importante sobre todo para interpretar las reacciones de la sociedad rural), serían otros tantos signos que desmienten la pasiva y masiva aceptación del régimen franquista por parte del pueblo español. ${ }^{6}$ No nos engañemos, sin embargo; la oposición activa fue un fenómeno minoritario. Como, por otra parte, ocurre siempre que se trata de regímenes fuertemente represivos y de carácter totalitario. No vamos aquí a tratar acerca de la naturaleza del régimen franquista, objetivo que queda fuera de las pretensiones de este estudio, pero seguimos la corriente historiográfica que afirma su carácter fascista, al menos durante los años que abarca este estudio. ${ }^{7}$ Carácter, además, que le atribuyeron desde el primer momento los que se enfrentaron a él y del que extrajeron parte de su legitimación y señas de identidad. La resistencia antifranquista, por tanto, se alinea bajo la bandera de los movimientos antifascistas puestos en pie durante la segunda guerra mundial.

En la medida de lo posible, este estudio quiere tener también un carácter comparativo en relación con los otros movimientos de resistencia,

6 Michael Richards insiste en esta misma idea cuando afirma que «a menudo, se organiza y se simboliza una resistencia al margen de la actividad política. En tiempos de Franco, la educación, la religión, la prensa la radio y la censura de la literatura tenían como objeto la despolitización de la conciencia social. E inevitablemente la resistencia se configuró en conformidad con el alcance de este régimen autoritario [...] el rechazo logró expresarse a través de una especie de cinismo popular, articulado entre las rendijas de la retórica oficial que prometía el cumplimiento del "destino" o la "trascendencia de la nación"». Michael Richards, Un tiempo..., op. cit., pp. 165-166. También la idea de las "pequeñas rebeldías cotidianas", desarrollada por James C. Scott para las sociedades campesinas en su libro Weapons of the weak. Everyday forms of peasant resistance. Yale University Press, 1985, es pertinente en este contexto, dado, además, que nos vamos a centrar en el Aragón rural.

7 Seguimos el análisis del franquismo como un régimen fascista realizado por Julián Casanova en "La sombra del franquismo: ignorar la historia y huir del pasado», en Julián Casanova, Ángela Cenarro, Julita Cifuentes, M. ${ }^{a}$ Pilar Maluenda, M. ${ }^{a}$ Pilar Salomón: El pasado oculto. Fascismo y violencia en Aragón (1936-1939). Siglo XXI, Madrid, 1992, pp. 1-28. Existe una reedición en Mira Editores, Zaragoza, 1999. 
principalmente con respecto a la Resistencia francesa, primer jalón de la lucha armada en lo que a la región aragonesa se refiere. Es imposible entender gran parte de la táctica y la mentalidad de los guerrilleros aragoneses sin tener en cuenta este preámbulo. Sin embargo, la lucha de los guerrilleros españoles en el interior ha sido pasada por alto en los numerosos estudios que analizan los movimientos de resistencia europeos contra el fascismo. Encontramos una amplísima bibliografía referida a la Resistencia francesa (que no olvida la participación de los españoles en ella), a los partisanos italianos, yugoslavos o griegos o incluso a la resistencia alemana. Pero la resistencia española parece quedar fuera de este marco analítico, cuando lo cierto es que compartió con el resto de estos movimientos cronología, objetivos, tácticas de lucha y discurso político, aunque con indudables especificidades derivadas de la situación política española al término de la segunda guerra mundial, cuando el fascismo ya había sido vencido en el resto de Europa. Sin embargo, dichos estudios nos van a proporcionar un marco teórico del que carecemos, a pesar del enfoque «militarista» de muchos de ellos, reflejado en un carácter excesivamente positivista y cuantitativo que se manifiesta en la atención casi exclusiva a los hechos militares, las fechas, los datos y los grandes protagonistas. La guerrilla española es tambien un fenómeno de resistencia al fascismo, analizable desde los mismos parámetros que sus homólogos europeos, a pesar de la ausencia de un invasor exterior. España no fue ocupada por un ejército extranjero, pero sí lo fue por un ejército y unas fuerzas represivas que se comportaron como auténticas fuerzas de ocupación, tanto durante la guerra civil como el tiempo que duró la lucha del régimen contra el maquis. ${ }^{8}$

Por una parte, pues, se trata de resituar este proceso en su marco europeo, aspecto frecuentemente desdeñado y, sin embargo, fundamental, pero sin olvidar que el movimiento guerrillero aragonés nace de la interacción de dos realidades: la externa, representada por los guerrilleros que penetran desde Francia hasta el interior, y la interna, la encarnada en los campesinos y campesinas que se incorporaron a la guerrilla desde sus lugares de origen

8 Así era visto tanto por la guerrilla del interior como por los exiliados, como se desprende del título de la conferencia del anarquista J. García Pradas, "España, colonia de "su" ejército", conferencia pronunciada en el Teatro Lanay, París, 27 de julio de 1947, y editada por la Secretaría de Propaganda de la Federación Local de París del MLE-CNT de España en Francia. 
y aquellos, mucho más numerosos, que dieron a los guerrilleros su apoyo y su simpatía, por lo cual pagaron un precio muy alto, a veces con la vida. El porqué del arraigo de la guerrilla aragonesa, de su aceptación entre determinados sectores de la población, de su implantación irregular y su naturaleza bipolar, materializada en la existencia de dos agrupaciones guerrilleras sin apenas contacto entre sí, son otros de los problemas que plantea la investigación, y a los cuales se tratará de dar respuesta en las páginas que siguen.

La documentación escrita a la que se ha recurrrido para elaborar esta investigación tiene, básicamente, dos orígenes, divergentes entre sí. Por un lado, los informes elaborados por la Guardia Civil, principal instancia represora del maquis, y que han sido consultados en los gobiernos civiles de Zaragoza, Castellón y Teruel (donde esta documentación se halla en el Archivo Histórico Provincial). En el Gobierno Civil de Huesca se nos negó la existencia de dicha documentación, por lo cual para cubrir esta provincia se han utilizado los informes mensuales enviados por el jefe provincial de Falange a la Delegación Nacional de Provincias, consultados en el Archivo General de la Administración, así como informes de la comandancia de Jaca consultados en la Dirección General de la Guardia Civil, en Madrid. En esta Dirección General se nos denegó el acceso al grueso de la documentación, pero creemos que la consulta de los partes en los gobiernos civiles ha subsanado en la medida de lo posible este contratiempo. Para completar la información, se han consultado también varios archivos municipales de las tres provincias aragonesas, así como parte de la Causa General (en el Archivo Histórico Nacional) y documentación de origen militar. Con ello, tenemos una de las visiones a las que aludíamos más arriba, la de las fuerzas del orden y las autoridades franquistas. Por otro lado, en el Archivo del Comité Central del PCE hemos tenido acceso a una ingente cantidad de documentación generada por los propios guerrilleros y por la dirección en Francia, así como prensa y propaganda clandestinas. Algunas personas, como Sixto Agudo, Jesús de Cos o Irène Tenèze, han facilitado también amablemente la consulta de sus archivos y documentos personales. Y la documentación se ha completado en archivos hemerográficos, principalmente en las hemerotecas de Zaragoza y Madrid y en la de la Bibliothèque Nationale de France, la más fructífera puesto que en Francia no sólo no existía la censura que amordazaba a la prensa española, sino que el tema de la guerrilla española se siguió con notable interés, sobre todo con ocasión de las «invasiones del valle de Arán». 
Pero sobre todo, se ha tenido en cuenta que la resistencia armada, la guerrilla, el maquis, no puede ser entendido como un fenómeno de naturaleza exclusivamente política, a riesgo de quedarnos en la superficie de los hechos. La guerrilla responde a motivaciones de carácter político, sin duda, pero sobre todo a un determinado contexto social que hace posible ya no sólo su existencia, sino sobre todo su pervivencia en el tiempo. Todo movimiento guerrillero precisa de un apoyo social, de una identificación entre la lucha guerrillera y los intereses de una capa de la población, la que le proporciona ayuda, apoyo y efectivos. Otro objetivo, pues, era localizar esos elementos de identificación y averiguar en qué medida el movimiento guerrillero respondía a los intereses de la sociedad campesina aragonesa en la cual se implantó, aunque nunca en perfecta simbiosis. De ahí la necesidad de recurrir al nivel local, a un análisis casi microhistórico para entender actitudes, acuerdos, desacuerdos, apoyos y rechazos. ${ }^{9} Y$ de ahí, también, que en este estudio el carácter cualitativo predomine sobre el cuantitativo, poco expresivo debido, principalmente, a lo fragmentario de la documentación, y a que lo que se busca no es establecer series numéricas (guerrilleros muertos, enlaces detenidos, bajas de las fuerzas del orden, sabotajes...), sino captar la esencia del problema, historiarlo desde una metodología más próxima a la antropología histórica que a la clásica historia cuantitativa, que además dejaría fuera de nuestro estudio un elemento fundamental para comprender el funcionamiento de la guerrilla pero imposible de cuantificar: los apoyos, enlaces, etc., de ésta en el seno de la sociedad campesina. ${ }^{10}$

9 Suscribimos la opinión del historiador J.R. Corbin cuando afirma la importancia del análisis local para comprender fenómenos históricos de ámbito nacional: «Local events determined by local structures often constructed national processes», en J.R. Corbin, The anarchist passion. Class in conflict in Southern Spain, 1810-1965. Avebury/Ashgate, Hants, Brooklyn, 1993, p. 198.

10 En este predominio de lo cualitativo sobre lo cuantitativo, seguimos la argumentación del historiador y antropólogo H.R. Kedward: «It is acknowledged that some 400000 men were available in the FFI after the Liberation in the whole of France, and of these some 120000 enrolled in the regular French armies. But none of these putative or confirmed figures give any indication of the numbers of active supporteers, carers or providers, agents de liaison, or medical personnel. Their Resistance has no statistical representation, not even an elusive one. It can only be written qualitatively, though quantitative judgements of depht and intensity filter through in the telling of their story». En H.R. Kedward, In search of the maquis. Rural resistance in southern France. Clarendon Press, Oxford, 1994, p. 281. Por otra parte, estudios como el de Fernanda Romeu (Mas allá..., op. cit.), que sí tuvo acceso a una documentación completa (la de la Dirección General de la Guardia Civil) nos dispensan, además, de realizar este trabajo, puesto que sus datos son obviamente mucho más completos en este sentido. De ahí que nos centremos sobre todo en el aspecto interpretativo de la investigación, mucho más descuidado en general en los estudios acerca de la guerrilla. 
En tal sentido, el estudio de la resistencia armada en Aragón requiere de la recuperación de un elemento imprescindible, pero a menudo desdeñado por la historiografía clásica: la memoria que los hechos han dejado en sus protagonistas o testigos más directos. En esa intersección entre la historia y la memoria es donde la investigación puede alcanzar su dimensión más fructífera. Nos sería imposible acceder al conocimiento real de estos procesos si, además de historiarlos con el recurso a la documentación disponible (fragmentaria, dispersa y, en demasiadas ocasiones, parcial), no investigásemos la huella que éstos han dejado en la memoria colectiva. Una huella que enlaza el pasado con el presente y lo hace más inteligible, que permite descubrir una memoria marcada por la violencia y por el miedo, en la cual los silencios son tan expresivos como las palabras. En esta memoria, la resistencia armada se enlaza con la conflictividad vivida durante la guerra civil y con las vivencias posteriores a la «época de los maquis», permitiéndonos estructurar el relato y enmarcarlo en el tiempo largo de las mentalidades y las actitudes colectivas. La resistencia armada, la guerrilla, marcó la experiencia y la memoria de una generación de aragoneses que recrean en sus palabras el duro ambiente de aquellos años cuarenta vividos, en el campo aragonés, a través del doble temor suscitado por los guerrilleros y por sus represores. Por lo tanto, la historia oral es otro de los puntales, un puntal imprescindible, en el que se sustenta este trabajo.

La memoria colectiva, las experiencias individuales y la vida cotidiana forman parte también de la historia de la guerrilla. ${ }^{11}$ Mediante el uso

11 En los estudios más recientes acerca de los fenómenos de resistencia en la Europa de la segunda guerra mundial se presta especial atención a estos procesos de la vida cotidiana, sobre todo con el objetivo de desmitificar dichos fenómenos. Así ocurre con la corriente alemana de la Alltagsgeschichte (ver, por ejemplo, Alf Lütdke, "De los héroes de la Resistencia a los coautores. "Alltagsgeschichte" en Alemania", Ayer, n. ${ }^{\circ} 19,1995$, pp. 4969) o con la francesa de la «histoire de la vie quotidienne», desde la que se estudian fenómenos como la vida de los franceses bajo la ocupación o durante el régimen de Vichy. Esta corriente hace uso de una historia sociocultural alejada de anteriores mitificaciones para mostrar que no todos los franceses participaron en la Resistencia y explicar fenómenos conflictivos y silenciados como la colaboración o la depuración. Ver por ejemplo J.P. Azéma y François Bédarida, Vichy et les Français. Fayard, París, 1992.

En España no nos enfrentamos al problema de la mitificación, sino más bien al contrario; sin embargo, el estudio de la vida cotidiana nos puede ayudar a comprender una resistencia que ha sido habitualmente explicada desde la hostilidad o desde la exaltación militante. Además, historiadoras como Dolores Ramos o Pilar Folguera han insistido en la importancia de este concepto de "vida cotidiana" para escribir la historia del primer franquismo. Ver M. ${ }^{a}$ Dolores Ramos y Francisco Javier Pereira, «El matrimonio del cielo y el 
de las fuentes orales podemos no sólo cubrir los «huecos» que quedan tras el análisis de la documentación escrita, sino también acceder a una perspectiva nueva del fenómeno que estudiamos. Como investigadora interesada en los fenómenos de vida cotidiana, en la historia "desde abajo", en la historia de los sin historia, no podía pasar por alto esta faceta del objeto de estudio. La guerrilla ha dejado una profunda huella en la memoria colectiva de amplias zonas del Aragón rural; ha dado lugar a tradiciones de carácter oral que se repiten en forma de relato mitificado de una población a otra; ha generado una determinada forma de convivir con un pasado que en ocasiones es demasiado traumático y necesita ser transformado en mito o en silencio, un silencio que no significa olvido. Pero con el uso de las fuentes orales no sólo accedemos a la vivencia subjetiva de la lucha armada, aunque también ésta nos interese como objeto de estudio; como indica Ronald Fraser citando a Luisa Passerini, "la historia oral nos permite conocer el entramado de lo privado y lo público que crea y mantiene las relaciones sociales, como redes, grupos y subgrupos que forman parte de entidades más largas [...] Tanto la solidaridad social como los conflictos de la vida cotidiana son expresiones de la interacción de lo objetivo - $\mathrm{O}$ sea, lo dado-y lo subjetivo». ${ }^{12}$ Sin conocer esta interacción entre lo objetivo y lo subjetivo, entre lo racional y lo irracional, no podemos entender la virulencia con la que se vivió la guerrilla en algunas zonas del Aragón rural, como el Maestrazgo turolense, ni las motivaciones de algunas de la acciones guerrilleras, ni los comportamientos de la población. Las relaciones sociales que funcionan en los núcleos rurales no siempre responden a un estricto análisis de clase, sino que se estructuran en torno a las denominadas «lealtades primordiales» de parentesco, de vecindad, etc. En las poblaciones pequeñas existen complejas redes de relación que explican por qué un notorio derechista local esconde un guerrillero en su casa, o un pastor paupérrimo denuncia una partida. Y sólo las fuentes orales nos abren el conocimiento de estas complejas redes.

infierno. Una alegoría de la vida cotidiana en el franquismo (1939-1952)», en Concepción Campos Luque y M. ${ }^{a}$ José González Castillejo (coords.), Mujeres y dictaduras en España y América: el largo camino. Universidad de Málaga, Málaga, 1996, pp. 123-147, o Pilar Folguera, "La construcción de lo cotidiano durante los primeros años del franquismo", en Luis Castells (ed.), La historia de la vida cotidiana, Ayer, n. ${ }^{\circ}$ 19, 1995, pp. 135-164.

12 Ronald Fraser, "La historia oral como historia desde abajo», en Pedro Ruiz Torres (ed.), La historiografía, Ayer, n. ${ }^{\circ} 12,1993$, pp. 79-92, cita en p. 81. 
Además, es sobre todo a través de las fuentes orales como tomamos conciencia de la importancia de un sujeto desdeñado en ocasiones en este tipo de estudios: las mujeres. La adopción de una perspectiva de género es fundamental a la hora de interpretar el contexto en el que se movieron los guerrilleros (y guerrilleras, que también las hubo). Las mujeres, que están íntimamente imbricadas en una sociedad rural de carácter patriarcal pero organizada en torno a redes de parentesco y vecindad que las incluyen, tuvieron un protagonismo destacado en estos hechos. Lejos de mantenerse al margen de la lucha, las mujeres aragonesas tomaron partido movidas, principalmente, por lealtades de parentesco, o por una conciencia política preexistente que las había llevado a participar en las colectividades anarquistas o en organizaciones políticas de izquierdas (aunque éstas son las menos). Lo que está claro es que el apoyo de las mujeres a sus parientes, hijos, maridos, padres o hermanos en el monte, fue vital para su supervivencia. Y que sufrieron directamente las consecuencias de la ola de represión que las autoridades desencadenaron en las zonas guerrilleras. ${ }^{13}$

Por lo tanto, a lo largo de esta investigación hemos utilizado tanto el telescopio como el microscopio, pasando del nivel «macro» al «micro». Del panorama conflictivo de lucha entre el fascismo y el antifascismo, que caracteriza a una Europa convulsionada por la segunda guerra mundial y sus consecuencias, a la experiencia cotidiana de un campesino obligado a delatar a su vecino que se ha "echado al monte», o la de una masovera atenazada por el miedo a la aparición de un grupo de hombres armados en su masía, fueran éstos guardias civiles o guerrilleros: en ocasiones, poco importaba a los ojos de un determinado sector del campesinado que se sentía atrapado entre dos fuegos, en un conflicto ajeno pero en el cual estaba inmerso irreversiblemente. La amplitud del territorio elegido, la región aragonesa, permite establecer comparaciones entre zonas en las que el fenó-

13 Fernanda Romeu es la investigadora que más se ha preocupado de estas mujeres, guerrilleras, enlaces o encargadas del suministro de los guerrilleros. Ver Más allá..., op. cit. En Francia, en los estudios acerca de la Resistencia francesa, se presta una atención creciente a las mujeres, y hay varias monografías sobre este tema. Ver Marie-Louise Coudert, Elles, la Résistance. Messidor, París, 1983; Ania Francos, Il était des femmes dans la Résistance. J'ai lu, París, 1985; Margaret Collins Weitz, Sisters in the Résistance: how women fought to free France. Wiley, Nueva York, 1995; o el monográfico coordinado por Françoise Thébaud, Clio. Histoire, femmes et sociétés. N. ${ }^{\circ}$ 1: Résistances et Libérations. Presses Universitaires du Mirail, Toulouse, 1995. 
meno tuvo características marcadamente diferentes. Facilita, también, establecer una tipología que permita la comparación con otras guerrillas antifascistas europeas. Y, por último, nos revela un aspecto poco conocido de nuestro pasado. En esta investigación entendemos la guerrilla como un fenómeno amplio, resultado de la interacción de un conflicto de carácter político con una conflictividad específicamente rural, y, por tanto, su estudio nos proporciona claves para entender cómo vivieron los campesinos y campesinas aragoneses los primeros años del franquismo, los de su implantación y consolidación, pero, a la vez, los únicos años en los que «los vencidos» vivieron con la esperanza real y fundada de llegar a acabar con un tipo de régimen que los ejércitos aliados habían derrotado en el resto de Europa. La esperanza murió, y hubo que esperar a que lo hiciese el dictador para que de nuevo renaciese una ilusión semejante. Pero, para muchos de los protagonistas de esta historia, ya era demasiado tarde. Combatientes en un frente invisible, habían sido vencidos por segunda vez. 


\section{HABLAR DE RESISTENCIA EN LA ESPAÑA DE POSGUERRA}

\subsection{Formas de resistencia en la sociedad campesina}

El hombre es el único ser que consume sin producir. No da leche, no pone huevos, es demasiado débil para tirar del arado y su velocidad ni siquiera le permite atrapar conejos. Sin embargo, es dueño y señor de todos los animales. Los hace trabajar, les da el mínimo necesario para mantenerse y lo demás se lo guarda para él. Nuestro trabajo labora la tierra, nuestro estiércol la abona y, sin embargo, no existe uno de nosotros que posea algo más que su pellejo.

(George Orwell, Rebelión en la granja)

La guerrilla antifranquista que se desarrolló en zonas rurales tiene un marcado componente de conflictividad campesina. ${ }^{14}$ Una conflictividad ligada al nivel local, relacionada con la alteración de las relaciones sociales en el seno de la sociedad rural, con los usos y el reparto de la tierra, con la

14 En un trabajo anterior se insistía en la necesidad de «conectar su carácter de movimiento político, organizado, con la adhesión de numerosos campesinos no politizados, o al menos, no pertenecientes a las estructuras creadas por el PCE». Mercedes Yusta, La guera de los vencidos. El maquis en el Maestrazgo turolense, 1940-1950. Institución Fernando el Católico, Zaragoza, 1999, p. 29.

Frente a la definición más reduccionista de «campesinado» utilizada por Theodor Shanin, que incluye en esta categoría únicamente a los propietarios de tierra, adoptamos la de Eduardo Sevilla-Guzmán, que incluye a todos aquellos individuos que trabajan la tierra, sean poseedores de ella o no, lo que engloba también a arrendatarios, aparceros o jornaleros sin tierra. Eduardo Sevilla Guzmán, La evolución del campesinado en España. Península, Barcelona, 1979, p. 25. 
imposición desde fuera de un sistema centralista que la población rural percibió como amenazador. El origen y desarrollo de la guerrilla antifranquista presenta, por lo tanto, una doble vertiente. Por un lado, es un movimiento de oposición y resistencia política contra el régimen fascista implantado en España tras la guerra civil. Pero, por otro, refleja conflictos en el seno de la sociedad rural que ya existían antes de 1936, fracturas en el seno de esta sociedad que la guerra civil vino a agrandar y a las que añadió otras nuevas, puesto que la posguerra se caracteriza por una ruptura total de las normas de convivencia entre «vencedores» $\mathrm{y}$ "vencidos».

La dinámica de la conflictividad vivida en el campo aragonés (el escenario de la guerrilla) no puede explicarse recurriendo únicamente a factores políticos, y junto a la lucha abierta de los guerrilleros se produjeron fenómenos de resistencia encubierta que, en ocasiones, enlazaban directamente con la lucha armada. La represión, las nuevas leyes económicas del régimen o la reestructuración de la vida local, que otorgó un poder casi omnímodo a las elites que anteriormente lo ostentaban de una forma más integrada, a través de las redes creadas por un sistema caciquil mediante el cual el campesino podía obtener un beneficio directo de su fidelidad al cacique, provocaron una reacción negativa por parte de un sector no desdeñable de la sociedad rural. Un sector que se vio despojado, sometido a leyes represivas y desprotegido frente al poder estatal encarnado en los nuevos dirigentes locales, que en ocasiones no eran tan nuevos y que obtenían del sistema beneficios y prebendas.

Varios autores han aludido a la conflictividad campesina originada durante la crisis agraria de los años treinta como un elemento desencadenante de la guerra civil; una guerra en la cual las oligarquías agrarias se alinearon en el bando de la sublevación, mientras que el campesinado más pobre, ínfimos propietarios y jornaleros, eran sus antagonistas naturales en la continuación de una conflictividad anterior a la guerra. Este argumento se ha utilizado sobre todo en estudios llevados a cabo en los territorios latifundistas del sur de España, en los cuales esta tradición de rebelión campesina era muy antigua y visible. Así lo especifican autores como Francisco Moreno, para quien «la represión [en Córdoba] se hizo siempre al dictado de la oligarquía agraria» e iba encaminada al sometimiento del campesinado, o Francisco Cobo Romero, que señala que «la agudización de los enfrentamientos entre el campesinado, de una parte, y los grupos sociales privilegiados de la burguesía agraria y los medianos y grandes pro- 
pietarios o arrendatarios rústicos, de otra, en un marco de crisis agraria generalizada, fue el resultado de la pretensión de estos últimos por aumentar el grado de explotación del trabajo campesino, mediante su subordinación a la mediana y gran propiedad agrícola y la virtual eliminación de todas aquellas prácticas que soportaban el específico "orden moral campesino”. La última pretensión chocó contra la fortaleza alcanzada por las organizaciones e instrumentos de resistencia de naturaleza política y sindical sostenida por el campesinado, y de manera preferente por los jornaleros». ${ }^{15}$ En Aragón, a pesar de que no se suele considerar un área latifundista, también se produjeron conflictos ente jornaleros y propietarios, aunque la situación no era tan extrema como en el sur de España, entre otras cosas por la escasa incidencia de la Ley de Reforma Agraria, que apenas llegó a aplicarse en zonas localizadas de la provincia de Zaragoza. Pero la ley sirvió para canalizar el descontento de unos y las esperanzas de otros, y a lo largo de la década existió una conflictividad, en general de baja intensidad, en torno a la cuestión de la tierra. ${ }^{16}$

En el párrafo citado anteriormente, Francisco Cobo Romero aludía a un «orden moral campesino». Éste es un concepto semejante al que Edward Thompson acuñó para referirse a los conflictos sociales de la Inglaterra del siglo XVIII, el de "economía moral de la multitud», término que el antropólogo H.R. Kedward sugería que podía reescribirse como "economía moral del campesinado" para aludir a actitudes contemporáneas del campesinado, particularmente en la Francia rural de la segunda guerra mundial. De este modo, aunque no lo especifica, Cobo Romero está aludiendo a un carácter "prepolítico", o, mejor dicho, que puede manifestarse por medios no políticos, de los conflictos entre el campesinado y sus explotadores. Y, por lo tanto, abre la vía para explicar una con-

15 Francisco Moreno Gómez, «La represión en la España campesina», en García Delgado (ed.), El primer franquismo. España durante la segunda guerra mundial. Siglo XXI, Madrid, 1989, pp. 189-207, cita en p. 190; este autor encadena la represión puramente «de posguerra» con la producida a raíz de la temprana aparición de la guerrilla. Francisco Cobo Romero, Conflicto rural y violencia politica. El largo camino hacia la dictadura. Jaén, 1917-1950. Universidad de Jaén, Jaén, 1998, p. 52.

16 Esta conflictividad de los años treinta consistirá en ocupaciones de fincas en varios municipios de Teruel, huelgas en la zona latifundista de La Violada en Huesca, y conflictos de clase entre patronos y jornaleros en las zonas de la ribera del Cinca y las Cinco Villas. Ángela Cenarro, Cruzados..., op. cit., pp. 32-33. 
flictividad que puede expresarse de forma diferente a la de un enfrentamiento político abierto. Ésta es la situación que se produjo tras la imposición del régimen franquista: las organizaciones de tipo político o sindical fueron prohibidas y aniquiladas, pero ese "orden moral campesino" permaneció y buscó otras vías para manifestarse y defenderse, vías abiertamente políticas aunque clandestinas, como la reconstrucción de estas organizaciones o el apoyo consciente a la guerrilla, o soterradas, manifestación de la conflictividad interna del campesinado y de su reacción frente a un régimen impuesto desde fuera, como las pequeñas rebeldías cotidianas. Con la adopción de actitudes de rebeldía los campesinos no estaban luchando abiertamente contra el régimen, sino defendiendo sus modos tradicionales de vida, amenazados por el «nuevo orden». Lo cual no debe hacernos olvidar que un sector del campesinado, básicamente el que se sintió amenazado por la política agraria de la República, se alineó al lado de los vencedores y participó en sus estructuras de poder y represión.

No es fácil, sin embargo, establecer con precisión qué sector del campesinado se colocó a cada lado de la línea de fractura y por qué. Las divisiones en la sociedad rural no responden a estrictos criterios de clase, sino que en el seno de las comunidades se establecen relaciones de tipo vertical, que atraviesan las diferentes capas sociales. En palabras de Juan Pro Ruiz, "existen muchas conductas y relaciones sociales que no pueden ser explicadas en esos términos [de clase], y [...] sólo la atención a los casos particulares, incluidos los casos extremos y excepcionales, nos puede acercar al conocimiento de cómo funcionan las relaciones entre las personas». ${ }^{17}$ Las relaciones personales (de vecindad, de parentesco...) pueden (y suelen) condicionar el resto de relaciones y estratificaciones que existen dentro de las comunidades pequeñas, incluida la adscripción política o el posicionamiento frente a un conflicto violento, como la guerra civil o la actividad de la guerrilla. Y a pesar de que, por supuesto, existen relaciones jerárquicas entre los individuos que componen una comunidad, las relaciones dentro de ésta quedan mejor definidas si recurrimos al concepto de «red»: es decir, relaciones multilineales entre los vecinos, redes que implican obligaciones de solidaridad o ayuda mutua, relaciones de proximidad

17 Juan Pro Ruiz, «Las élites en la España liberal: clases y redes en la definición del espacio social (1808-1931)», Historia social, n. ${ }^{\circ} 21$, 1995, pp. 47-69, cita en p. 62. 
entre personas pertenecientes a estratos socioeconómicos muy diferentes. «Por supuesto que se imponía la jerarquía en las relaciones entre amos y sus servidores y trabajadores, pero incluso así, había una especie de intimidad entre algunos amos y las familias de los trabajadores que contradecía esa desigualdad». ${ }^{18}$ De lo que se trata, en suma, es de averiguar qué tipo de factores influyen, en el nivel local, en los comportamientos de los diferentes individuos que componen la población campesina de una zona determinada ante un conflicto de características tan extremas como es la presencia de un movimiento guerrillero cuya actividad afecta necesariamente a la comunidad. Y no sólo la afecta, sino que la comunidad campesina se ve directamente implicada en el conflicto y participa en él, sea poniéndose del lado de los insurgentes, sea colaborando con sus represores.

Por lo tanto, no podemos analizar al campesinado español como un «bloque», ni siquiera como una "clase social de baja clasicidad», como sugiere Theodor Shanin. En su interior, como vemos, hay divisiones y líneas de fractura que tampoco corresponden exactamente a las tradicionales divisiones socioeconómicas de clase. Para acercarnos a la compleja organización interna de las sociedades rurales hemos acudido al concepto de "red», y para integrar en nuestro análisis la forma en que se materializan las divisiones sociales puede ser útil el concepto de "facción", recogido por Hamza Alavi, que integra las relaciones jerárquicas patrón-cliente, habituales en la sociedad rural, y «describe adecuadamente la forma más predominante de interacción política campesina tal y como se observa en las sociedades campesinas». Alavi aclara que «los alineamientos faccionales atraviesan los alineamientos de clase», y, por tanto, el conflicto entre facciones no es un conflicto de clase, no tiene expresión ideológica y consiste en la lucha por el control de los recursos, y no por cambios en la estructura social. ${ }^{19} \mathrm{La}$ aplicación de este concepto debe matizarse si queremos utilizarlo para comprender los alineamientos del campesinado frente al conflicto guerrillero de los años cuarenta en Aragón, un conflicto en el que sí están presentes un componente ideológico y un enfrentamiento de clase, percibidos muy claramente por los guerrilleros pero no superponibles

18 Susan Harding, Rehacer Ibieca. La vida rural en Aragón en los tiempos de Franco. Instituto Aragonés de Antropología, Zaragoza, 1999 (1. a ed., 1984), p. 103.

19 Hamza Alavi, Las clases campesinas y las lealtades primordiales. Anagrama, Barcelona, 1976 , p. 89. 
directamente al campesinado aragonés, cuya estructura interna no se puede explicar recurriendo únicamente a un análisis marxista clásico.

En su estudio acerca de los orígenes de la guerra civil en Navarra y el País Vasco, Javier Ugarte realiza un análisis sobre una comunidad campesina, Salinillas, típica del mundo rural tradicional, en un momento de cambios acelerados. Esta comunidad se caracterizaba por unas relaciones complejas, que se traducían, por una parte, en unidad frente al extraño, y, por otra, en una división interna en la que la posición de cada individuo estaba determinada por «lealtades fundamentalmente personales, familiares, de patronazgo [...] etc., antes que horizontales o socioprofesionales, sin que estas últimas estuvieran excluidas, claro, a la altura de los treinta». ${ }^{20}$ La socialización política introducida por la República, que iba a cristalizar en dos bloques, las «derechas» y las «izquierdas», estaba determinada por esos vínculos y lealtades personales, más que por programas políticos o ideologías más o menos abstractas. Es lo que Ugarte denomina «banderías", grupos de afinidad en los que se mezclan estas lealtades de tipo personal con aspectos relacionados con el estatus socioeconómico, la ideología, etc. Las pugnas en el seno de la localidad se reproducen en el momento en que tiene lugar un "suceso extraordinario» que rompe la cotidianeidad y exige una respuesta y una movilización, como puede ser la guerra civil o esa prolongación de la guerra bajo otros parámetros que conocemos con el nombre de maquis o guerrilla. El análisis de Ugarte, que recurre a la «descripción densa» para analizar el comportamiento de la localidad frente al suceso extraordinario de la sublevación militar, nos proporciona un modelo que permite aproximarnos al impacto que la aparición de la guerrilla produjo en poblaciones como las del Maestrazgo turolense o el Prepirineo oscense, y comprobar que en el compromiso de cada individuo con los guerrilleros o las fuerzas represivas actuaban las relaciones y lealtades establecidas con el resto de miembros de la comunidad.

Esto, en cuanto a las líneas internas de fractura que dividen a la sociedad campesina. Respecto a la relación entre la sociedad campesina y el Estado, en los años cuarenta detectamos, a raíz del movimiento guerrillero, una confrontación entre éste y un sector importante del campesinado. En los

20 Javier Ugarte, La nueva Covadonga insurgente. Orígenes sociales y culturales de la sublevación de 1936 en Navarra y el País Vasco. Biblioteca Nueva, Madrid, 1998, p. 14. 
estudios acerca de los movimientos guerrilleros del siglo XX, que se producen principalmente en el llamado Tercer Mundo, encontramos elementos de análisis que podemos aplicar para comprender mejor este componente campesino de una guerrilla que se desarrolló casi íntegramente en un medio rural, el de la España de los años cuarenta, en el que las relaciones sociales no estaban absolutamente condicionadas por la lógica capitalista. ${ }^{21}$ Dichos análisis se centran, sobre todo, en desmentir la supuesta «pasividad» del elemento campesino y en resaltar cómo, por el contrario, las sociedades campesinas tienen sus propios mecanismos de defensa frente a las agresiones a sus modos tradicionales de vida. La sociedad agraria se caracteriza, ciertamente, por el poder de sus tradiciones culturales, que observadas desde fuera producen una impresión de inmovilismo y conservadurismo, de rechazo de todo lo nuevo. "Hay quienes piensan, sin embargo — puntualiza Julián Casanova-, que tales características no son inherentes a la cultura campesina, sino más bien una consecuencia de la "cultura de la represión" bajo la que se desenvuelve la existencia de una gran parte del campesinado». ${ }^{22}$

El campesinado es susceptible de movilización cuando la comunidad campesina se ve desestabilizada por elementos exteriores a ella, como puede ser una amenaza externa que conduzca a un colapso político interior. Las revueltas campesinas contemporáneas precisan, pues, de una situación de crisis de autoridad, y la movilización se produce a través de la intervención de fuerzas externas. Según Eric Wolf, en un contexto de grandes transformaciones políticas (y la guerra civil y sus consecuencias proporcionan ese marco) el Estado es percibido como hostil y negativo,

21 Con ello nos referimos a lo que José Manuel Naredo denomina una «sociedad agraria tradicional», caracterizada por el escaso desarrollo tecnológico y la abundancia de mano de obra, lo que determina que las relaciones sociales en el campo también sigan una pauta tradicional, y que cierto tipo de lealtades predominen sobre las relaciones de clase. Ver José Manuel Naredo, La evolución de la agricultura en España (1940-1990). Servicio de Publicaciones de la Universidad de Granada, Granada, 1996. Ello no significa que suscribamos la teoría de la modernización, pues los recientes avances en historia agraria y particularmente en la rama denominada "historia ecológica» demuestran que los métodos de la agricultura tradicional no implican, más bien al contrario, un desaprovechamiento de los recursos o un bajo rendimiento agrícola.

22 Julián Casanova, «Sociedad rural, movimientos campesinos y colectivizaciones. Reflexiones para un debate», en Julián Casanova (comp.), El sueño igualitario: campesinado y colectivizaciones en la España republicana, 1936-1939. Institución Fernando el Católico, Zaragoza, 1988, pp. 7-15, cita en p. 8. 
contrario a la utopía campesina de una «aldea libre», lo que le sirve a Wolf para afirmar que los campesinos son anarquistas por naturaleza. ${ }^{23}$ Los desórdenes campesinos, por lo tanto, no son respuestas a problemas locales, sino «reacciones locales ante disturbios sociales de gran importancia, que han sido causados por importantes cambios en la sociedad». ${ }^{24}$ Esta reacción contra el Estado, ajeno a la comunidad campesina pero que establece con ella lazos caracterizados, sobre todo, por la presencia de mecanismos de control social (funcionarios, recaudadores de impuestos, fuerzas represivas), puede adoptar la forma de "pequeñas rebeldías cotidianas» (hurtos, ignorancia fingida, ocultación de cosechas para eludir el control económico sobre los recursos), pero también de un conflicto abierto que toma la forma de lucha soterrada e inarticulada, a falta de los mecanismos apropiados para constituir una oposición más organizada.

El campesinado desarrolla unas estrategias de autodefensa frente a lo que es percibido como una agresión externa: «Sus actos individuales de tra-

23 Julián Casanova, por el contrario, indica que el anarquismo no es la expresión ideológica del mundo agrario, puesto que la estructrura social de las comunidades campesinas, en las que predominan otro tipo de vínculos sobre las relaciones de clase, hacen a éstas poco permeables a una ideología que predica la división de la comunidad. En esto coincide con el análisis del anarquismo español (concretamente andaluz) realizado por J.R. Corbin, que desde un punto de vista antropológico refuta las tesis que califican al anarquismo de "milenarista», recalcando lo que tiene de racional, antirreligioso y, sobre todo, revolucionario, con lo cual llega a la conclusión de que es un movimiento más urbano que rural. Y Susan Harding, que ha estudiado la colectivización en la población oscense de Ibieca, señala que «el nuevo orden, el comunismo libertario, recurría a algunos valores rurales. Sin embargo, no era una derivación natural del ethos rural de la región, sino la visión colectiva de un movimiento anarquista con cincuenta años de historia en España y con focos tanto urbanos (incluso internacionales) como rurales». En nuestro caso, de lo que se trata es de señalar la resistencia de las comunidades campesinas a ser gestionadas "desde fuera», más aún si esta gestión recurre a medios represivos. La conflictividad vivida en el seno de las colectividades aragonesas (contra las que, sin embargo, no hubo una oposición frontal por parte del campesinado) puede interpretarse también desde este prisma, puesto que no nacieron espontáneamente de las comunidades campesinas sino que fueron inducidas por las milicias anarquistas. Julián Casanova, Anarquismo y revolución en la sociedad rural aragonesa, 1936-1938. Siglo XXI, Madrid, 1985, p. 34 y ss., y «Campesinado y colectivizaciones en Aragón: la lucha por el control de la Revolución», en Julián Casanova (comp.), El sueño igualitario: campesinado y colectivizaciones en la España republicana, 1936-1939. Institución Fernando el Católico, Zaragoza, 1988, pp. 49-60; J.R. Corbin, The anarchist passion..., op. cit.; Susan Harding, Rehacer Ibieca..., op. cit., p. 71.

24 Eric Wolf, Las luchas campesinas del siglo XX. Siglo XXI, Madrid, 1979, pp. 375410, cita en p. 407. 
bajo intencionadamente lento y evasión de impuestos, reforzados a menudo por una venerable cultura popular de la resistencia, y multiplicados por muchos miles, pueden tener como resultado un completo fracaso de las políticas soñadas por sus supuestos superiores en la capital. El Estado puede responder de varios modos. Las políticas pueden ser reformadas según unas expectativas más realistas. Pueden ser mantenidas pero reforzadas por incentivos positivos destinados a animar el cumplimiento voluntario. Y, por supuesto, el estado puede escoger simplemente emplear más coerción». ${ }^{25}$ Esta última opción fue la elegida por el régimen franquista, que había impuesto un régimen económico de tipo autárquico que, si seguimos la interpretación de Michael Richards, encubría una forma de "castigo» contra la población potencialmente hostil al régimen: «El racionamiento [que es consecuencia directa de la política autárquica] se convirtió, pues, en un metodo de represión más. La fabricación de artículos alimenticios en pequeña escala y la venta "ilegal" de esos productos suponía una medida de defensa en la lucha. No se trataba de explotar la situación con el fin de generar dinero, sino todo un acto político». Además, señalemos que este que podríamos calificar de «acto de rebeldía cotidiana» era frecuentemente llevado a cabo por mujeres, especialmente mujeres de republicanos encarcelados, huidos o muertos, que no recibían ninguna ayuda estatal y que eran las encargadas de asegurar la supervivencia de la familia. ${ }^{26}$

A estas consideraciones se añade una particularidad propia de las sociedades campesinas, que, como señalábamos más arriba, mantienen su propio «orden moral» al margen de lo considerado legal o ilegal por las autoridades. Ello da lugar a una cultura popular de la rebeldía, de la inversión de la autoridad y su sustitución por una autoridad que emana del propio campesinado o de aquellos que se proclaman defensores de sus intereses frente a los abusos del poder central. Este caso de búsqueda de una identidad propia, en la que se integra la figura del «bandido-héroe» y las acciones de la guerrilla son legitimadas en la mentalidad campesina, dando lugar a una nueva forma de autoridad, ha sido muy bien analizado por H.R. Kedward en el caso de la Resistencia en la zona sur de Francia, en la cual confluyen el patriotismo y la defensa del interés económico personal,

25 James C. Scott, «Formas cotidianas de rebelión campesina», Historia social, n. ${ }^{\circ} 38$, 1997, pp. 13-39, cita en p. 16.

26 Michael Richards, Un tiempo..., op. cit., pp. 155-156. 
a la vez que existe una culture of the outlaw, una cultura del "fuera de la ley», el ladrón que roba a los ricos para repartirlo entre los pobres. ${ }^{27}$ Los mismos argumentos son utilizados por Eric Hobsbawm cuando analiza formas primitivas de rebeldía campesina o el «bandolerismo social». El estatuto de "bandido social» es en ocasiones, incluso, reivindicado por los propios guerrilleros, que se insertan por esta vía en la tradición y el mundo mental campesino: así ocurrió con la Resistencia rural en Provenza durante la segunda guerra mundial. ${ }^{28}$ También en los primeros momentos de la resistencia griega hubo una relación entre los guerrilleros y los «bandidos de honor", como los haiduks o los clephtés: aunque carentes de ideología política, se integraron en los maquis junto a los guerrilleros politizados. ${ }^{29}$ Y el propio Hobsbawm señala que en algunas de las actuaciones de las guerrillas españolas de posguerra, principalmente cuando llevaban a cabo «expropiaciones» para financiar la revolución (lo que en el lenguaje guerrillero se conoce como "golpes económicos»), los guerrilleros (principalmente los anarquistas) adoptaban los métodos y los mitos del bandolero social, el bandido «noble» que sigue la antiquísima tradición de Robin Hood de robar al rico para favorecer al pobre. Como ejemplos, Hobsbawm alude a la guerrilla anarquista de Andalucía y al guerrillero catalán Quico Sabaté, también anarquista. Los guerrilleros aragoneses utilizaron, asimismo, la táctica de los "golpes económicos» como forma de financiar la guerrilla, aunque parece que la idea de reparto de los recursos entre el campesinado desposeído no estaba presente en su discurso. ${ }^{30}$

En Aragón, estas expresiones de rebeldía y conflictividad campesina han sido también analizadas para períodos anteriores a la crisis agraria de

27 H.R. Kedward, In search of the maquis. Rural resistance in southern France, 19421944. Clarendon Press, Oxford, 1994, p. 286.

28 J.M. Guillon, «Le maquis, une résurgence du banditisme social?», Provence historique, n. ${ }^{\circ} 147,1986$, pp. 57-67.

29 André Kédros, La résistance grecque (1940-1944). Robert Laffont, París, 1966.

30 Eric Hobsbawm, Rebeldes primitivos. Estudio de las formas arcaicas de los movimientos sociales en los siglos XIX y XX. Ariel, Barcelona, 1968, y Bandidos. Ariel, Barcelona, 1976, pp. 139-163. Respecto a Sabaté, es una interesante figura que despierta tanto simpatía como aversión. Pero desde el punto de vista de la mitificación, reúne en su persona muchas de las características del «bandolero noble», como las leyendas acerca de su invulnerabilidad o la negativa popular a creer en su muerte. Lo mismo ocurre con otros guerrilleros, como el leonés Manuel Girón: todavía hoy, en Ponferrada, pueden verse pintadas que rezan: «Girón luchó por tu libertad», o «Girón vive». Esta pervivencia del mito, así como los homenajes de que han sido objeto recientemente ambos guerrilleros, forman parte de un movimiento social de reivindicación de la rehabilitación de la memoria de los guerrilleros antifranquistas. 
los años treinta. Alberto Sabio aplica los conceptos desarrollados por Scott para analizar la conflictividad encubierta que se produjo alrededor del uso y aprovechamiento de los montes oscenses en la segunda mitad del siglo XIX. Señala que «[...] la lucha por el control de los pastos, de la madera y de la leña constituyó un motivo frecuente de conflictividad social entre los vecinos y la Administración forestal. [...] Muchas veces se trataba de un enfrentamiento soterrado pero permanente, disperso pero cotidiano, poco espectacular pero muy efectivo, por reivindicaciones concretas, difíciles de integrar en un proyecto general. [...] Toda esta conflictividad campesina redundó con frecuencia en distintas formas de "atentado contra la propiedad", ya fuera ésta privada o pública; bajo esta expresión se englobaban muy distintos comportamientos y actitudes delictivas, desde los más elementales (hurtos de leña, de frutos) hasta aquellos algo más premeditados, como la ocupación de fincas». ${ }^{31}$ Por lo tanto, existía en el campo aragonés una tradición de resistencia a la autoridad enmarcable en un tiempo largo, y que formaba parte de la mentalidad campesina. Por eso, las acciones de la guerrilla eran contempladas desde un prisma muy diferente al de las autoridades franquistas, y sus supuestos «delitos» no eran percibidos como tales por un sector de estos campesinos, siempre y cuando las acciones no les perjudicasen a ellos directamente. De ahí, también, el rechazo de la política económica del régimen, lo extendido del pequeño estraperlo, al que ya hemos hecho alusión anteriormente, o la ocultación de parte de las cosechas (entendidos como una práctica social de supervivencia), medidas que los guerrilleros apoyaban y a las que daban publicidad como formas de resistencia al régimen, enlazando así unas prácticas de resistencia genuinas de la sociedad rural con la lucha armada, de carácter político, llevada a cabo por ellos. Ambas formas de resistencia, armada y "cotidiana", se imbrican en este caso y confluyen en un objetivo común.

\subsection{La resistencia europea contra el fascismo. La resistencia española en el marco europeo}

En el capítulo anterior hemos tratado de trazar un cuadro, necesariamente muy general, de los conflictos que afectan al campesinado, así como

31 Alberto Sabio, Los montes públicos en Huesca (1859-1950). El monte no se improvisa. Instituto de Estudios Altoaragoneses, Huesca, 1997, pp. 209-210. 
de sus formas específicas de resistencia que pueden influir (o confluir) en el establecimiento de un movimiento guerrillero. Hemos analizado, pues, el componente que podríamos denominar «interno» o «social» que formará parte de la guerrilla antifranquista. A continuación, analizaremos el otro elemento de la lucha armada: el que, en un contexto europeo de lucha contra el fascismo y el nazismo, es importado "desde fuera» al interior de la sociedad aragonesa por los hombres que, llegados desde Francia tras su participacion en la Resistencia, constituirán el núcleo de la lucha guerrillera.

Se trata, pues, de la intersección de dos niveles: un nivel local representado por el campesinado aragonés, cuyos conflictos internos específicos en los años cuarenta se analizarán más adelante, y un nivel supranacional, encarnado en los guerrilleros que penetraron en el interior de España en 1944, con una práctica de la lucha clandestina y un ideario político antifascista que databa de la guerra civil pero había sido enriquecido por la experiencia europea, de la que extrajeron una determinada concepción de la lucha armada que chocaba, en ocasiones, con la realidad social vivida en el interior, una realidad en gran medida desconocida por ellos. A este desconocimiento se unían unas ideas preconcebidas adquiridas en la experiencia de la lucha contra los invasores nazis, lucha en la que contaron con un fuerte apoyo de la población y una estructura militarizada con un alto grado de organización, medios y fuerza.

La invasión de una gran parte de Europa por los ejércitos hitlerianos, que comenzó ya en 1938 con la anexión de Austria y continuará con la invasión de Checoslovaquia y de Polonia (invasión esta última que desencadenó la reacción internacional y, con ella, la guerra), provocó la emergencia de un movimiento de resistencia en todos los países de la Europa ocupada, incluidas Alemania e Italia. Dicho movimiento se alimentaba, en primera instancia, del antifascismo militante de las organizaciones de izquierdas durante los años treinta. El antifascismo internacional había tenido una primera ocasión de ejercitarse durante la guerra civil española; encontraremos a muchos excombatientes de las Brigadas Internacionales en las filas de la resistencia de sus respectivos países.

Pero antes de entrar en materia, aunque nuestro objetivo no es realizar una caracterización de los distintos regímenes fascistas que se instalaron en el poder en Europa durante los años treinta, creemos importante 
destacar una serie de características comunes a todos ellos, para mostrar que el régimen de Franco participaba de estas características básicas, lo que nos permitirá incluirlo en el grupo de los regímenes fascistas y, al mismo tiempo, resaltar las homogeneidades existenes entre los diferentes movimientos de resistencia europeos. No podemos establecer un marco comparativo para el estudio de las resistencias europeas si antes no afirmamos que el tipo de régimen al que se enfrentaron era básicamente el mismo, más allá de las peculiaridades nacionales que indudablemente presenta cada uno de ellos.

Frente a la caracterización de J.J. Linz del franquismo como régimen autoritario, nos alineamos con la tendencia representada principalmente por Julián Casanova y Paul Preston, que utilizando los métodos de la historia comparada (algo que pretendemos realizar en este capítulo respecto a la resistencia antifascista) se basan en un análisis de clase para llegar a la conclusión de que todos estos regímenes tuvieron un objetivo principal: solucionar la crisis de los años treinta, que había adquirido características diferentes en cada país, pero que básicamente consistía en una crisis del poder de las elites tradicionales frente a la irrupción de las masas en la política, en medio de una coyuntura económica deprimida. ${ }^{32}$ Aunque inicialmente los partidos u organizaciones de tipo fascista se presentaron como una solución «nueva» y su discurso estaba teñido de anticapitalismo, lo cierto es que en su ascensión al poder contaron con el apoyo de los grupos derechistas y las elites tradicionales, y que sus enemigos eran los situados a la izquierda en el espectro político. En todos los casos, surgió una "coalición reaccionaria» que se instaló en el poder y cuya función social era la de frenar los avances democráticos de la sociedad, representados sobre todo por el acceso a la arena política de la clase obrera organizada. Las

32 J.J. Linz, "Una teoría de régimen autoritario. El caso de España», en Stanley G. Payne, Politica y sociedad en la España del siglo XX. Akal, Madrid, 1978, pp. 205-263. Sus tesis son también sostenidas por Javier Tusell, La dictadura de Franco. Alianza Editorial, Madrid, 1988. Frente a esta interpretación del franquismo como régimen autoritario, están las tesis de Julián Casanova, «La sombra del franquismo...», op. cit., y Paul Preston, La política de la venganza. El fascismo y el militarismo en la España del siglo XX. Península, Barcelona, 1997, que defienden la calificación del franquismo como dictadura fascista, cosa que ya había hecho el historiador italiano Luciano Casali, el primero en definir el franquismo como un fascismo en "Introduzione. Il fascismo spagnolo», en Luciano Casali (ed.), Per una definizione della dittatura franchista. Franco Angeli, Milán, 1990, pp. 7-37. 
soluciones adoptadas en cada caso difieren en cuanto al grado de radicalismo o el recurso a la violencia, pero la función social desempeñada por los regímenes fascistas fue en todos los casos la misma: asegurar el poder de esta "coalición reaccionaria» y aniquilar los avances conseguidos por la clase obrera.

En el estudio comparado de Gregory M. Luebbert, se hace hincapié en la misma idea: para este autor, la diferencia entre regímenes fascistas y autoritarios no es una cuestión de grado sino de esencia, con lo que volvemos a la necesidad de considerar la «función social» desempeñada por el Estado, así como a los beneficiarios de su política, para calificar un régimen de fascista. El elemento decisivo para la configuración de un régimen fascista como alternativa al liberalismo es la forma que adopta la alianza campociudad, concretamente la alianza establecida por el campesinado familiar para conseguir llevar a cabo sus proyectos políticos. Cuando éste se alinea con la burguesía urbana, en lugar de decantarse por el proletariado urbano, el régimen resultante es un régimen fascista. Luebbert entiende por «campesinado familiar» aquel estrato de la sociedad campesina que vive de explotaciones familiares que le permiten autoabastecerse y participar en el mercado, pero que no alcanzan un nivel de producción suficiente para contratar mano de obra. Sin embargo, en el caso español esta definición resulta demasiado genérica por la enorme variedad de situaciones que se dan en el seno del campesinado, debido principalmente al tamaño variable de las explotaciones y, sobre todo, porque, al analizar el desarrollo de la guerra civil y la represión de posguerra, no resulta tan claro que el campesinado familiar se uniera en bloque a la sublevación militar. Otros factores, como la distribución geográfica, la influencia de determinadas organizaciones políticas en cada localidad y la política de «banderías» de la que hablaba Javier Ugarte y a la que aludíamos en el capítulo anterior, tuvieron una importante influencia en los alineamientos de la población rural en general, y del campesinado familiar en particular, aunque el pequeño propietario se sintió amenazado, a grandes rasgos, por los planteamientos de la Segunda República en materia de política agraria. ${ }^{33}$

33 Gregory M. Luebbert, Liberalismo, fascismo o socialdemocracia. Clases sociales y origenes politicos de los regimenes de la Europa de entreguerras. Prensas Universitarias de Zaragoza, Zaragoza, 1997. Ver también Edward Malefakis, Reforma agraria y revolución campesina en la España del siglo XX. Ariel, Barcelona, 1976. 
En España, la gravedad de la crisis, así como la violencia que se aplicó para su resolución, permiten calificar el golpe de Estado de 1936 como una salida a la crisis de tipo fascista, al margen del papel más o menos importante representado en esta solución por el partido propiamente fascista, la Falange Española, que en todo caso se convirtió en el partido único del régimen. La libertad de acción que se dejó al partido es una cuestión secundaria, y recordemos que su protagonismo en la represión que siguió a la guerra es crucial, a pesar de su escasa fuerza movilizadora en la coyuntura anterior a $1936 .{ }^{34}$ Además, en la consolidación del régimen franquista tanto el discurso como los signos exteriores del fascismo fueron utilizados con profusión; el régimen reclamó para sí la calificación de «fascista" y sus simpatías hacia las potencias del Eje eran más que evidentes. En este primer momento incide también Josep Fontana para caracterizar el régimen franquista, puesto que fue entonces, principalmente durante los primeros años de la segunda guerra mundial, cuando éste definió su naturaleza y objetivos, libre de tapujos y de los intereses internacionales que le llevarían posteriormente a renunciar a esos signos de identidad fascistas. Por todo ello, la semejanza y las posibilidades de comparación con los regímenes alemán e italiano quedan fuera de dudas. ${ }^{35} \mathrm{Y}$ no está de más añadir que una gran parte de la población española percibió el régimen franquista como un régimen fascista, en concreto sus opositores, los potenciales integrantes de la resistencia antifranquista; como señala Encarna Nicolás, «en los pueblos de la extensa geografía española la represión fue sentida como una persecución fascista, semejante a la que se desarrollaba en la Alemania nacional-socialista o en la Italia fascista. Ninguno de los testimonios orales recogidos hasta ahora califica a la dictadura de otra manera». ${ }^{36}$

Sin embargo, en la historiografía europea o anglosajona dedicada a los movimientos de resistencia europeos de los años cuarenta no se hace ape-

34 Estas cuestiones, así como el debate historiográfico acerca de la naturaleza del franquismo, son tratadas a fondo por Ángela Cenarro en la introducción a su libro Cruzados..., op. cit., pp. 9-26.

35 En Josep Fontana, «Reflexiones sobre la naturaleza y las consecuencias del franquismo», en Josep Fontana (ed.), España bajo el franquismo. Crítica, Barcelona, 1986, pp. 9-38.

36 Encarna Nicolás, «Los poderes locales y la consolidación de la dictadura franquista", en Glicerio Sánchez Recio, El primer franquismo (1936-1959), Ayer, n. ${ }^{\circ} 33$, Madrid, 1999, pp. 65-85, cita en p. 74. 
nas alusión al caso español. La omisión se debe, principalmente, a que España no participó en la segunda guerra mundial, momento en el que emergieron en el resto de Europa estos movimientos, que surgían principalmente como una reacción frente a la invasión alemana y unían así un fuerte componente patriótico al carácter antifascista de la resistencia. Aunque esta forma de enfocar la cuestión es una simplificación historiográfica, probablemente nada inocente, de una realidad mucho más compleja, dado que en todos los países ocupados por las tropas alemanas o italianas se produjo en mayor o menor medida el fenómeno de la colaboración, que dividió a las poblaciones autóctonas en enfrentamientos que en ocasiones se aproximaban mucho a una guerra civil encubierta (caso de Francia o Italia) o, como en el caso griego, desembocaron en una auténtica guerra civil. Otros autores consideran que la resistencia en España fue un fenómeno excesivamente minoritario para que merezca estudiarse junto a otros fenómenos similares, lo cual supone desconocer o, al menos, minusvalorar tanto sus dimensiones reales como, sobre todo, el impacto que tuvo en la población, la brutal ola represiva que desató y su huella perdurable en la memoria colectiva. ${ }^{37}$

Probablemente, la historiografía que se ha dedicado de una forma más extensa al estudio de «su» resistencia contra el fascismo es la francesa, y es la que vamos a tomar como base para hablar de la resistencia europea, debido además a la importancia de la participación española en ella, que determinó gran parte de la táctica seguida por los guerrilleros españoles en el interior. En Francia, los estudios, memorias y conmemoraciones surgieron muy poco después de la Liberación (los primeros trabajos datan ya de finales de 1944), y la iniciativa partió de los propios resistentes. El más significativo es el ejemplo de Henri Michel, antiguo resistente él mismo, promotor del Comité d'Histoire de la Deuxième Guerre Mondiale y principal impulsor del inicio de los estudios acerca de la Resistencia y la ocupación.

37 En su obra sobre revolución y resistencia en la Europa mediterránea, y tras señalar la guerra de España como un acontecimiento de trascendental importancia para el desarrollo de las diferentes resistencias europeas contra el fascismo, como primer escenario en el que se enfrentaron fascismo y antifascismo, Tony Judt considera que después de 1939 España queda «fuera» del marco analítico, pues «there were a very little effective resistance against Franco after 1939, and the Spanihs revolution(s) were defeated and destroyed well before then». Tony Judt, "Introduction», en Tony Judt (ed.), Resistance and revolution in Mediterranean Europe 1939-1948. Routledge, Nueva Yok, 1989, pp. 1-25, cita en p. 9. 
La enorme producción bibliográfica a la que ha dado lugar la Resistencia se construye sobre la oposición entre lo que Jean-Marie Guillon denomina una «histoire savante» y la "histoire courante»: la historia académica, elaborada por profesionales de la historia y la historia-testimonio de los protagonistas, que se consideran a sí mismos depositarios de la "verdad» acerca de la Resistencia. Es una historiografía que a través de su larga trayectoria oscila al compás de las diferentes coyunturas políticas francesas, hasta que finalmente evoluciona de una historia conmemorativa y mítica a una "historia-problema». Aparece la preocupación por nuevos sujetos, que abre los márgenes cuidadosamente marcados por los guardianes de la memoria resistente, una memoria fijada sobre los acontecimientos militares y los grandes enfrentamientos armados, hacia la consideración de otras formas de resistir, protagonizadas por las mujeres, los extranjeros (entre ellos, los españoles), los miembros de las redes de asistencia... Aparecen también nuevos conceptos, como el de «resistencia civil»: «La Resistencia es sustituida por las resistencias». ${ }^{38}$

El tratamiento historiográfico privilegiado que ha recibido la Resistencia francesa la ha elevado a la categoría de paradigma de la resistencia europea contra el fascismo, hasta el punto de que uno de los historiadores más autorizados para realizar una valoración de dicha historiografía, François Bédarida, se pregunta si está justificado "tal galocentrismo», si es legítimo considerar, tanto en el plano conceptual como en el histórico, a la Resistencia francesa como punto de referencia del resto de resistencias europeas. Insiste, además, en que «la opresión y la resistencia son de todos los tiempos», y propone aplicar el término a diferentes contextos que no se reduzcan a los territorios ocupados por los ejércitos germano-italianos y a los seis años de la segunda guerra mundial..$^{39}$ De la definición restrictiva de «resistencia» ofrecida por Henri Michel en 1958, en la que establecía

38 El concepto de resistencia civil aparece desarrollado en la obra de Jacques Semelin, Sans armes face à Hitler: la résistance civile en Europe, 1939-1943. Payot, París, 1989. El entrecomillado es de Jean-Marie Guillon, "La Résistance, 50 ans et 2000 titres après», en Jean-Marie Guillon y Pierre Laborie (dirs.), Mémoire et Histoire: la Résistance. Privat, Toulouse, 1995, pp. 27-43, cita en p. 42. Las citas tomadas de obras en francés o en inglés han sido traducidas por la autora.

39 François Bédarida, «Sur le concept de Résistance», en Jean-Marie Guillon y Pierre Laborie (dirs.), Mémoire..., op. cit., pp. 45-50, citas en p. 46. 
claramente estos límites espacio-temporales e incluso especificaba el enemigo frente al cual se estructuraba esta resistencia (los ejércitos de Alemania, Italia y Japón), hemos pasado a un concepto amplio, al que François Bédarida define como «idealtipo», que permite la comparación entre diferentes fenómenos de resistencia y, sobre todo, nos autoriza a utilizar el término para hablar de la guerrilla antifranquista, incluyéndola entre las resistencias europeas contra regímenes de carácter fascista. ${ }^{40}$ Concretamente, para él el concepto de resistencia hace referencia a «La acción clandestina llevada a cabo en nombre de la dignidad del hombre por personas voluntarias que se organizan para luchar contra la dominación (y muy a menudo la ocupación) de su país por un régimen nazi o fascista, o satélite o aliado». ${ }^{41}$ Acción clandestina y voluntaria, lucha por la libertad y la dignidad frente a un régimen fascista o aliado: elementos, todos ellos, presentes en la guerrilla española.

Trazaremos a continuación las líneas básicas que caracterizaron a la Resistencia en Francia, que, por una parte, ha sido tomada como modelo historiográfico y, por otra, influiría decisivamente en la forma en que se llevó a cabo la lucha antifranquista en el interior de España. Sin embargo, establecer el inicio de la Resistencia francesa es complicado. Sus comienzos se caracterizaron más por actos individuales que por acciones organizadas, dado el marasmo en que la veloz conquista alemana sumió a la población. El primer acto de resistencia armada del que se tiene constancia es el denominado "atentado de Barbès», la muerte de un oficial de la Kriegsmarine a manos del comunista Pierre Georges, el futuro coronel Fabien, que tuvo lugar el 21 de agosto de 1941 en París. Pierre Georges, miembro de la OS (Organisation spéciale, la organización armada creada por el PCF en octubre de 1940), había combatido en la guerra de España, concretamente en el frente del Ebro y en la batalla de Aragón. Por tanto,

40 La definición de Henri Michel, en European resistance movements 1939-1945. First International Conference on the History of the Resistance Movements held at Liege-BruxellesBreendonk. September 1958. Pergamon Press, Londres, 1960, p. 1: «Nous entendons par Résistance la lutte menée d'abord clandestinement, puis au grand jour, par les peuples dont les territoires ont été occupés par les troupes de la coalition italo-germano-nippone [...]». Ello incluye, en este debate, las resistencias griega, yugoslava, belga, polaca, judía y, por supuesto, francesa. Las observaciones de François Bédarida, en "Sur le concept...», op. cit.

41 François Bédarida, "L'histoire de la Résistance, lectures d'hier, chantiers de demain», Vingtième siècle. Revue d'Histoire, n. ${ }^{\circ}$ 11, 1986, pp. 75-90. 
como les ocurría a muchos otros partisanos de toda Europa, su primera experiencia bélica antifascista databa de la guerra civil. ${ }^{42}$

Hasta noviembre de 1942, el territorio francés estuvo dividido en dos zonas con administraciones diferentes: la zona norte o zona ocupada, administrada directamente por los alemanes, y la zona sur, con un Gobierno colaboracionista a cuya cabeza estaba el mariscal Pétain, héroe de Verdún, que gozaba del favor de una parte significativa de la población, sobre todo en la Francia rural. El régimen de Vichy adoptó las formas de un estado totalitario y fascistizado; como ejemplo, baste decir que su política de persecución respecto a los judíos llegó a superar las exigencias alemanas. ${ }^{43}$ En cuanto a sus medidas contra los españoles refugiados en Francia, nos ocuparemos de ellas en el siguiente capítulo. La primera Resistencia armada, caracterizada por acciones como la del coronel Fabien y llevada a cabo principalmente por comunistas de la OS, tendrá por escenario la zona norte, principalmente los centros urbanos, y como objetivo a los oficiales del ejército ocupante. En la zona sur, la ausencia del ocupante alemán dificultó la sensibilización de la población respecto a las acciones de los resistentes, percibidas en muchas ocasiones como actos de radicalismo político o de mero terrorismo, hasta que los franceses de la zona controlada por Vichy fueron identificando otros enemigos distintos a los alemanes: los colaboracionistas, las milicias organizadas por Darnand... Por el contrario, la resistencia en la zona norte encontró otras dificultades para desarrollarse, particularmente la fuerte estructura represiva desarrollada por los alemanes. La de la zona norte era una resistencia más urbana que rural, intelectual, y, a pesar de la actividad desplegada por la OS, llevó a cabo más actos de propaganda que acciones armadas. Para nuestro propósito comparativo, resulta más interesante la desarrollada en

42 Dominique Venner, Histoire critique de la Résistance. Pygmalion, París, 1995, pp. 215-224.

43 La polémica respecto al carácter fascista o no fascista del régimen de Vichy sigue abierta. Según Zeev Sternhell, la tendencia fascista estaba presente ya en la ideología política de la Tercera República y se manifiesta claramente en Vichy. Además, el antisemitismo declarado del régimen vichysta significa un inconfundible signo de identidad fascista para autores como Rita Thalmann. Pero la tendencia predominante entre los historiadores franceses es considerar que Vichy nació como un régimen autoritario que se fue fascistizando durante la ocupación, sobre todo a partir de 1942, hasta alcanzar un carácter plenamente fascista en 1944. 
la zona sur, y más la rural que la urbana, sobre todo a partir del momento en que la aparición de los maquis convirtió la lucha armada en un objetivo generalizado.

El mundo rural francés era en principio bastante impermeable a las acciones de la Resistencia. Ello se debía principalmente a la propaganda ruralista del régimen de Vichy, así como a la escasa implantación de partidos políticos y sindicatos en el campo. Además, la ausencia de una cultura de lo escrito dificultaba la difusión de la propaganda resistente. La Resistencia campesina en Francia se manifestaba a menudo de manera individual, "prepolítica», y revestía la forma de una sorda oposición a las disposiciones económicas del régimen petainista, como el Ravitaillement général, o a otras medidas como la Relève o el STO (Service du travail obligatoire). «No es por hostilidad ideológica, sino por un apego visceral a la libertad de producir o de vender por lo que se explican las múltiples críticas y recriminaciones del mundo rural hacia la Administración». ${ }^{44}$ Los mecanismos de control y los destinados a poner a la población a disposición de los alemanes impuestos por Vichy, comenzaron a percibirse con hostilidad cuando Pierre Laval instauró el sistema de la Relève en septiembre de 1942. Consistía ésta en un intercambio de trabajadores franceses para Alemania por prisioneros franceses, y fue visto como un auténtico «comercio de esclavos». ${ }^{45}$ Pero el verdadero revulsivo para la población francesa fue el establecimiento del STO en febrero de 1943, que se encuentra en el origen del establecimiento de los maquis, los campamentos en el monte que constituirían la base de la lucha armada. La función original de estos campamentos era servir de refugio a los jóvenes que huían al monte para eludir la obligación de cumplir el STO (que significaba trabajar para los alemanes) y que, una vez organizados y encuadrados por las organizaciones de resistencia (principalmente, l'Armée secrète, gaullista, o los Francs-Tireurs et partisans del PCF), pasaron al enfrentamiento armado contra las fuerzas de ocupación. Hasta esos momentos, la Resistencia era un fenómeno más urbano que rural, como venimos diciendo, y los campesinos eran vistos con desconfianza por los resistentes, que los consi-

44 Christian Font, «Les paysans et la Résistance, le modèle aveyronnais?», en La Résistance et les Français. Enjeux stratégiques et environnement social. Presses Universitaires de Rennes, Rennes, 1995, pp. 175-189, cita en p. 183.

45 H.R. Kedward, In search of the maquis..., op. cit., p. 4. 
deraban un puntal del régimen de Vichy, gran parte de cuya retórica se basaba en la adulación del campesinado y la exaltación de la vida rural. Pero tanto la Relève como el STO afectaron directamente a la población rural, que reaccionó apoyando al embrionario movimiento de resistencia y proporcionándole muchos de sus efectivos en forma de los jóvenes refractarios al STO.

Finalmente, el maquis (que había sido presentado por la propaganda del régimen como grupos de terroristas o bandidos) comenzó a obtener legitimidad ante los campesinos, que descubrían una convergencia de intereses con los resistentes. Además, las tradiciones de solidaridad y ayuda mutua del mundo rural predisponían a éstos a colaborar con los miembros de la comunidad que se unían a la Resistencia: la organización resistente era ajena al mundo rural (como ocurriría en España), pero se benefició de estas redes de solidaridad. A comprender las formas de resistencia del campesinado francés nos ayuda la siguiente observación de François Marcot: «la cultura campesina predispone más fácilmente a actos personales de solidaridad que a la propaganda, la organización o la lucha armada». ${ }^{46}$ Ello no impidió que en el mundo rural surgiesen iniciativas más organizadas de resistencia, como los "comités de defensa y de acción campesina» creados a partir de 1943, bajo la iniciativa de dirigentes comunistas. La presencia en muchas poblaciones del sur de Francia de la temible división Das Reich a partir de 1944 dirigió la represión alemana hacia los campesinos, con la intención de acabar con los focos de apoyo al maquis, y provocó un aumento de la simpatía campesina hacia los resistentes. ${ }^{47}$

A pesar de lo dicho, además de la experiencia vivida directamente por la población fue muy importante el papel desempeñado por la prensa clandestina, que funcionó como una correa de transmisión de información y, también, como medio de cohesión del movimiento de resistencia. $\mathrm{O}$ mejor dicho, de los diferentes movimientos de resistencia que surgieron

46 François Marcot, «Les paysans et la Résistance: problèmes d'une approche sociologique», en La Résistance et les Français..., op. cit., pp. 245-255, cita en p. 255.

47 La División Das Reich fue responsable de algunos de los actos represivos más sangrientos y brutales llevados a cabo por las fuerzas de ocupación contra la población civil, como la masacre cometida en la localidad de Oradour-sur-Glane, en la cual toda la población, que se componía sobre todo de mujeres, niños y ancianos, y entre la que había varios refugiados españoles, fue exterminada. 
en la zona sur. La actividad de los movimientos más importantes, Libération, Combat y Franc-tireur, que se unieron dando lugar a los MUR (Mouvements unifiés de la Résistance), estaba ligada a la publicación de sus respectivos órganos de expresión, que eran los que daban su nombre a cada uno de los movimientos. Claro que en este caso hablamos de otro tipo de resistencia, que no era la resistencia armada sino una resistencia de tipo intelectual y urbano, con base en la ciudad de Lyon, cuyos componentes eran sobre todo destacados representantes del mundo intelectual huidos de la zona ocupada. ${ }^{48}$

Pese a todo, la resistencia activa fue un fenómeno minoritario. En la zona sur, el régimen de Vichy gozaba de legitimidad ante un sector no desdeñable de la población. Incluso existía, en un principio, la opinión de que el pueblo francés había sido excepcionalmente bien tratado por los ocupantes, que en los primeros momentos no llevaron a cabo acciones represivas de amplitud y permitieron a la población, a través del Gobierno de Vichy, mantener la ilusión de que eran regidos por una Administración francesa (aunque esto ocultaba la total dependencia de Vichy respecto de la Administración alemana). En realidad, las medidas represivas comenzaron como respuesta a las primeras acciones armadas de la Resistencia. Para muchos, la confusión de los últimos meses de la Tercera República y la derrota militar habían desacreditado al régimen parlamentario, y el Gobierno de Vichy aparecía como una especie de Gobierno de salvación nacional, un Gobierno fuerte, centralizador y enormemente burocratizado. Su puesta al servicio de los intereses alemanes no fue evidente desde el principio. Por lo tanto, hubo un sector significativo de la poblacion (elementos de la derecha francesa, miembros del campesinado...) que tomó parte en las estructuras de este nuevo Estado, incluso de forma activa, ingresando en las milicias o desempeñando cargos burocráticos al servicio de Vichy o, directamente, de los alemanes. En particular, los fascistas franceses más recalcitrantes — como Marcel Déat, que concibió un proyecto

48 Un representante ilustre de este tipo de resistencia es el historiador de origen judío Marc Bloch, cofundador de la revista Annales y miembro del movimiento Franc-Tireur, con cuyo periódico Le Franc-Tireur colaboró habitualmente, además de publicar artículos en otras revistas de la Resistencia, como Les cahiers politiques (publicados por Lucien Febvre, el otro cofundador de Annales). Bloch fue detenido y fusilado en marzo de 1944. Ver Carole Fink, Marc Bloch: A life in History. Cambridge University Press, Nueva York, 1989. 
de partido único que no llegó a realizarse - no encontraban al régimen de Vichy lo suficientemente "fascista» y consideraban que pecaba de debilidad política, por lo cual se reagruparon en París y se pusieron directamente al servicio de los alemanes. ${ }^{49}$

Ante la existencia de una parte de la población que apoyaba al ocupante y a su representante en la zona sur (el régimen de Vichy), la Resistencia se convirtió en un conflicto interno entre adversarios políticos, en una lucha contra el régimen autoritario de Vichy y los franceses que lo sostenían, una guerra dentro de la guerra. Una vez que la totalidad de Francia fue ocupada por los alemanes, la acción armada de la Resistencia se centró en éstos, pero las rivalidades y las líneas de fractura entre franceses habían quedado ya bien definidas. Prueba de ello son los actos violentos, dirigidos y orquestados por los maquisards, llevados a cabo contra los acusados y las acusadas de colaboracionismo durante el proceso de depuración que siguió inmediatamente a la liberación del territorio. ${ }^{50}$ La Resistencia francesa fue, por lo tanto, una lucha contra un enemigo plural. Fue un movimiento tanto anti-Vichy como anti-alemán; contenía tanto un proyecto de liberación del territorio como un proyecto de futuro sobre cómo organizar este territorio tras la Liberación. La Resistencia francesa, a pesar de su pluralidad (hay en ella gaullistas, giraudistas, comunistas, socialistas...) logró, mientras duró la ocupación, convertirse en un movimiento más o menos unitario, aunque en su seno convivían, al menos, dos posibles proyectos de futuro, un proyecto revolucionario, preconizado por el

49 Michèle Cointet-Labrousse, Vichy et le fascisme. Les hommes, les structures et les pouvoirs. Complexe, Bruselas, 1987, pp. 94-104.

50 Las mujeres que habían tenido relaciones con alemanes durante la ocupación fueron un objetivo sañudamente perseguido, y, al igual que sucedió en la guerra civil española y que sucederá en la posguerra (pero en este caso por parte de los fascistas y derechistas), son objeto de una represión diferencial, cuya manifestación más "popular» y significativa desde un punto de vista simbólico es el rapado de la cabeza, la tonte. Ver Fabrice Virgili, "Les "tondues" à la Libération: le corps des femmes, objet d'une réapropiation", en Françoise Thébaud (coord.), Clio. Histoire, femmes et sociétés. N. ${ }^{1}$ : Résistances et Libérations. Presses Universitaires du Mirail, Toulouse, 1995, pp. 111-127, o Françoise Leclerc y Michèle Weindling, «La répression des femmes coupables d'avoir collaboré pendant l'occupation", en la misma revista, pp. 129-150. Desde una perspectiva filosófico-sociológica, que se centra más en las referencias visuales y simbólicas, Alain Brossat, Les tondues. Un carnaval moche. Manya, Levallois-Perret, 1992. Para el proceso de la depuración en general, Herbert Lottmann, La depuración. Tusquets, Barcelona, 1998. 
PCF, y el modelo que acabó imponiéndose, el de una República demócrata-liberal que enlazaba con tradiciones institucionales anteriores. ${ }^{51}$

Precisamente, esa existencia de un proyecto revolucionario por parte de los comunistas que se desarrolla en el seno del movimiento de resistencia es uno de los factores homogeneizadores de las distintas resistencias antifascistas nacionales. En todos los países en los que emergió un movimiento de resistencia, principalmente en los de la órbita mediterránea, el «viejo orden» anterior a la guerra y la ocupación entró en crisis; la resistencia no aspiraba solamente a liberar el país del ocupante, sino que en su interior se desarrollaron uno o varios modelos de Estado para reemplazar a las viejas formas caducas, que habían demostrado su fragilidad para hacer frente a las crisis de los años treinta y al nazifascismo. La resistencia fue, al mismo tiempo, una fuente de legitimidad y la cantera de la que surgieron las nuevas elites políticas. Fue así en el caso griego, el yugoslavo o el francés, que acabamos de describir: debido a la fragilidad que había demostrado la Tercera República frente a la crisis, la resistencia en Francia era "necesariamente revolucionaria», a diferencia del resto de países de la Europa noroccidental. De ahí la visibilidad alcanzada por el Partido Comunista en la Resistencia francesa, como ocurrió en Grecia, Yugoslavia o España, incluso en Italia, donde la resistencia no podía ya mirar hacia el pasado, un pasado liberal que resultaba demasiado lejano en 1940.

$\mathrm{Y}$ en este protagonismo de los comunistas en la resistencia encontramos un nexo que inserta a España en la historia de la Europa mediterránea durante los años cuarenta, puesto que estos luchadores resistentes, o al menos sus líderes, habían tenido su primera experiencia antifascista en la guerra civil española, encuadrados en las Brigadas Internacionales. La experiencia de la guerra civil española iba a ser «central en la formación de la imaginación política de la generación radical de los años cuarenta». Una experiencia que había dotado a los líderes comunistas de una perspectiva independiente de los dictados de la URSS, que había creado "una generación de potenciales titistas». En otras palabras, los líderes comunistas de las resistencias del sur de Europa habían recibido una educación partisana durante la guerra civil española, de la cual habían extraído experiencias

51 Ver H.R. Kedward, Naissance de la Résistance dans la France de Vichy. Idées et motivations, 1940-1942. Ed. Champ Vallon, Seyssel, 1989. 
tanto políticas como militares, y además una práctica política basada en la independencia y la toma de decisiones de acuerdo con las necesidades de la lucha. La resistencia durante la segunda guerra mundial completó este aprendizaje, y los comunistas desarrollaron un programa revolucionario destinado a obtener el control político en el seno del modelo de Estado que surgiese de las respectivas liberaciones. Pero un control político independiente, en gran medida, de las directrices marcadas por la URSS, cosa que es especialmente visible en los casos yugoslavo y griego. ${ }^{52}$

Esta relativa independencia planteaba problemas bastante complejos en el caso de partidos con una fuerte influencia soviética, como el PCF o el propio PCE. La misma independencia de los proyectos soviéticos que llevó al conflicto entre la URSS y Yugoslavia se expresó de forma individualizada en el seno de las organizaciones de resistencia controladas por partidos comunistas bajo la influencia de Stalin y que, sin embargo, fueron cantera de líderes independientes, portadores de un proyecto revolucionario que quizá no convenía al equilibrio de poderes que la URSS trataba de trazar para la Europa posbélica. Según Pierre Broué y Raymond Vacheron, "la estrategia estaliniana se impuso deberes hacia las democracias», y de ahí la decisión de disolver la Komintern en 1943, cuando la colaboración entre las fuerzas aliadas y el Ejército Rojo estaba en su apogeo. Dentro de esta estrategia, no convenía abrigar bajo el ala de los partidos comunistas a líderes demasiado radicales que pudieran hacer peligrar, como en Italia, «no solamente el fascismo mussoliniano, sino el propio sistema liberal». Esto nos lleva a considerar una compleja línea de fractura: la que señala los enfrentamientos en el seno de las propias organizaciones de resistencia, de las guerrillas y los maquis. Un conflicto que incluye liquidaciones de elementos trotskistas, "anarquizantes» o revisionistas. Es un conflicto que se dio en Francia y también en España, en el seno de las guerrillas de carácter comunista. ${ }^{53}$

En el caso griego también hubo una división entre las fuerzas de resistencia, pero las líneas de fractura eran mucho más claras, y desembocaron finalmente en un conflicto abierto. En Grecia, la Liberación derivó en guerra civil debido a la división entre las fuerzas que habían contribuido a ella y cuyas guerrillas no habían sido desmovilizadas, a que Grecia representaba

52 Tony Judt, «Introduction», en Tony Judt (ed.), Resistance and revolution..., op. cit. Entrecomillados, en pp. 9 y 10.

53 Pierre Broué y Raymond Vacheron, Meurtres au maquis. Grasset, París, 1997, p. 36. 
una confluencia de diferentes intereses internacionales (el papel de los británicos, apoyando al sector contrarrevolucionario de la resistencia, fue decisivo) y a que los comunistas no llegaron a obtener la legitimidad que la lucha resistente les proporcionó en Francia o en Italia. Una parte importante de la opinión pública griega, la correspondiente a una burguesía urbana, culta y generalmente anglófila, consideraba con alarma la existencia de un «peligro comunista» que podría manifestarse en toda su amplitud tras la Liberación, alarma acentuada por la proximidad de la Unión Soviética. A pesar de que este sector de la población era favorable a una acción resistente contra el ocupante alemán, desconfiaba del ala más radical de la resistencia, encabezada por el KKE (el partido comunista griego).

El KKE había sido diezmado por la represión estatal durante la dictadura del general Metaxás; a pesar de todo, logró establecer, junto con las centrales sindicales y otros pequeños partidos de izquierdas, su propio movimiento de resistencia siguiendo el modelo de frente nacional propugnado por la URSS: el EAM o Frente Nacional de Liberación, con un brazo armado, el ELAS (Ejército Nacional de Liberación). Éste coexistía con otros movimientos de resistencia de orientación democratacristiana, como la EDES (Unión Nacional Griega Democrática), dirigida desde el exilio por el general Plastiras, o el EKKA (Movimiento de Liberación Nacional y Social). En vísperas de la Liberación, el EAM controlado por los comunistas era el organismo de resistencia más fuerte, cosa que contrariaba los intereses de la política inglesa en los Balcanes: Inglaterra estaba ya, de hecho, interviniendo en la política griega a través del SOE (Special Operations Executive), organismo creado a espaldas del Intelligence Service para el apoyo de la resistencia en los países ocupados. Durante las luchas por la Liberación, el EAM intentó formar un Gobierno de unidad nacional sin conseguirlo; la guerrilla comunista se amotinó y ello provocó la intervención armada de los ingleses, que apoyaban a las facciones no comunistas de la resistencia. Finalmente, la situación tomó la forma de una guerra civil llevada a cabo como una guerra de guerrillas, al término de la cual, en 1949, el proyecto revolucionario de los comunistas griegos fue definitivamente vencido.

Grecia constituye un expresivo ejemplo de la influencia de la política internacional en los conflictos internos de una nación en la Europa posbélica, y de las escasas oportunidades que tenía una revolución nacional que no favorecía los intereses de los grandes, que ya habían llevado a cabo 
su propio reparto de zonas de influencia en Yalta. La guerrilla española, como veremos más adelante, se asemeja en esto a la griega: en su dependencia de una coyuntura internacional que condicionaba su triunfo o su derrota a los intereses de los bloques diseñados en Yalta, y a los intereses de una política internacional en la cual los guerrilleros comunistas no eran mucho más que meros peones con escasa autonomía real. Conclusión a la que se llega, es importante no olvidarlo, considerando ambos conflictos desde una perspectiva internacional, a vista de pájaro. Respecto a sus dimensiones nacionales respectivas, las conclusiones son otras muy distintas, tanto en lo que respecta a la represión y las pérdidas sufridas por la población como a las fracturas duraderas que abrieron o profundizaron.

En su dimensión nacional, ambos países presentan también destacables semejanzas. Sobre todo, en cuanto a la implicación de la población rural en la resistencia controlada por los comunistas, y en la relación de esta resistencia campesina con la lucha por el control de la producción agraria. Durante la guerra mundial, en Grecia el problema de la supervivencia de la población pasó a ocupar un lugar central, sobre todo durante las grandes hambrunas de 1942 y 1943. El Estado, controlado por las fuerzas ocupantes, puso en marcha un sistema de apropiación de la producción agrícola que dio lugar a un amplio mercado negro y a redes clandestinas de abastecimiento. La protección de estas redes clandestinas de distribución de la producción campesina fue un objetivo prioritario de la resistencia en el ámbito rural griego, y algo semejante ocurrió en el caso español; como veremos, los guerrilleros españoles realizaron llamamientos constantes al campesinado para que rechazase la política económica del franquismo y para que luchase contra la expropiación de sus cosechas. Por último, también consideramos importante destacar el hecho de que la guerra civil griega y la guerrilla española son contemporáneas, detalle que no pasó desapercibido a los ojos de los guerrilleros españoles, que tomaron las guerrillas comunistas griegas como ejemplo e inspiración y siguieron atentamente su evolución, como quedó reflejado en sus publicaciones. ${ }^{54}$

54 Para el caso griego, ver André Kédros, La Résistance grecque (1940-1944). Robert Laffont, París, 1966 (texto histórico-testimonial, puesto que André Kédros es un resistente griego comunista «de primera hora»); David H. Close (ed.), The greek civil war. Studies of polarization. Routledge, Londres y Nueva York, 1993; o John O. Iatrides y Linda Wrigley (eds.), Greece at the crossroads. The civil war and its legacy. The Pensylvannia State University Press, 1995. 
En cuanto a la resistencia en Alemania (un país que, al igual que la España franquista, no sufrió la invasión de un ejército ocupante, aparte del propio), el partido comunista no desempeñó un papel trascendental. Aniquilado durante la represión que siguió al establecimiento del régimen nazi, a ello se unió el rechazo de algunos antifascistas a admitir la colaboración con la (por otra parte, débil) resistencia comunista: la resistencia debía ser, por definición, anti-totalitaria, y los lazos que unían a los partidos comunistas con la URSS eran demasiado evidentes antes de la disolución de la Komintern en 1943. La fuerza represiva del todopoderoso Estado nazi, en Alemania, dificultaba por otro lado toda acción de resistencia, hasta el punto de que la historiografía alemana ha desarrollado dos conceptos distintos de resistencia, denominados con dos términos diferentes: widerstand para los movimientos de resistencia como tales, y resistenz para las reacciones individuales en lo cotidiano. Incluso el exilio es considerado como forma de resistencia, por lo que tiene de rechazo a aceptar el nuevo orden y por la interacción entre los exiliados y los que consiguieron desarrollar algún tipo de resistencia en el interior (minoritaria, débil, reducida muchas veces a actos de propaganda y de denuncia). Considerada en principio por la historiografía una resistencia «de elite», sociológicamente compuesta por miembros de la burguesía o incluso de la aristocracia y la derecha nacional-conservadora, recientemente se ha redescubierto la importancia de la resistencia de izquierdas (sobre todo, a partir de los estudios de Martin Broszat y su equipo del Institut für Zeitgeschichte) y se ha incidido en la importancia de estas resistencias cotidianas, que encontraremos también en la España franquista. En suma, para hablar de la resistencia en Alemania es necesario resaltar la pluralidad de acciones que entran dentro de lo que podemos considerar como «resistencia»; «la resistencia es en primer lugar una actitud, una reacción: reacción de rechazo ante una amenaza, una situación o una acción juzgadas inaceptables por razones morales, religiosas, políticas o económicas». 55

55 Gilbert Krebs, «Des jeunes contre le national-socialisme. Une face mal connue de la résistance au Troisième Reich», en Gilbert Krebs y Gérard Schnelin (eds.), Exil et Résistance au national-socialisme, 1933-1945. Publications de l'Institut Allemand-Université de la Sorbonne, Asnières, 1998, pp. 109-134, cita en p. 110. Ver también François Bédarida, "Les résistants Allemands», en L'Allemagne de Hitler. Éditions du Seuil, París, 1996, pp. 366-383, y Der Widerstand gegen Nationalsozialismus [32. Congreso de Historiadores Alemanes en Hamburgo], Stuttgart, 1979. 
Con esta observación realizada para el caso alemán, volvemos a la consideración de los rasgos comunes que presenta la resistencia española con sus homólogas europeas. Como en el caso alemán, y salvando las evidentes diferencias entre uno y otro caso, en España nos encontramos frente a un Estado fascista en un país no ocupado por un ejército extranjero, donde confluye un movimiento de resistencia armada, organizado y estructurado, con la resistencia cotidiana llevada a cabo por la población en su vivencia del día a día y con la importancia de un exilio masivo que establece fuertes lazos con el movimiento de resistencia interior. En suma, encontramos varios temas recurrentes en el análisis de las diferentes resistencias europeas: la importancia crucial del papel desempeñado por el campesinado y el mundo rural; las reacciones negativas de éste frente a las políticas económicas del ocupante o el régimen en el poder; la división de la población autóctona entre los que rechazan el fascismo y los que colaboran con él; el peso de los comunistas en el seno de los movimientos de resistencia; la existencia de una represión selectiva, basada en criterios de clase; la coexistencia de diversas formas de resistencia, la cual no se reduce a la resistencia armada sino que incluye también la llamada resistencia civil o resistencia cotidiana; y, por último, la conexión entre la resistencia interior y el exilio. Temas que reaparecerán cuando tratemos la guerrilla aragonesa, como caso a la vez específico y paradigmático de la resistencia armada contra el franquismo. 



\section{GESTACIÓN DE LA GUERRILLA ARAGONESA}

\subsection{La semilla del descontento: horizontes de conflictividad en Aragón en los años cuarenta}

Primero de abril de 1939: la guerra civil española ha terminado. Entiéndase: la guerra oficial, abierta. En cuanto a Aragón, era ya una región oficialmente pacificada desde la ofensiva de la primavera de 1938, que reconquistó su franja oriental y expulsó a los ejércitos republicanos hacia Levante y Cataluña. A lo largo de este proceso, se produjo en dichos territorios el mismo fenómeno que ya había tenido lugar en la vertiente occidental: la construcción ex novo del Estado franquista. El proceso tiene dos caras: la depuración y eliminación de los anteriores ocupantes del poder así como la represión de los simpatizantes de la causa republicana, y la elevación a los puestos de responsabilidad de representantes de la nueva legalidad, nacida de la fuerza de las armas.

Aragón había quedado dividida en 1936 por un frente que partió la región en dos zonas con evoluciones muy diferentes durante la contienda. La parte oriental vivió hasta la primavera de 1938, en que fue reconquistada por las tropas nacionales, un proceso revolucionario inducido, a grandes rasgos, por las columnas de milicianos procedentes de Cataluña, que recuperaron la franja oriental de la región, en la que inicialmente había triunfado la sublevación. La expresión más visible de este proceso fue la creación de colectividades agrarias, generalmente de carácter anarquista, en casi todas las poblaciones que quedaron bajo control republicano. Colectividades en las que participaron también numerosos miembros de 
la UGT, que llegaron a hacerse con el control de algunas de ellas, e incluso de Izquierda Republicana, como ocurrió con ciertas colectividades del Bajo Aragón como Mas de las Matas. ${ }^{56}$ Este proceso no se llevó a cabo sin resistencias y violencias, y la guerra se vivió como un conflicto interno que dividió a las comunidades y puso de manifiesto antiguas rencillas y tensiones entre los vecinos. Además de las previsibles represalias contra los derechistas o las "gentes de orden» en cada localidad, abundaron los enfrentamientos entre los colectivistas y los labradores partidarios de la explotación individual de las tierras.

Más allá de los enfrentamientos que dividieron a las fuerzas republicanas a partir de los sucesos de mayo de 1937, y de los conflictos entre los sindicatos CNT y UGT por hacerse con el control de la revolución (conflictos que se saldaron con la disolución del Consejo de Aragón, en agosto de 1937), creemos que esta conflictividad tiene su origen, no tanto en dos prácticas sindicales diferentes (puesto que, además, ambas centrales estaban de acuerdo en el respeto a la pequeña propiedad privada) como en la resistencia de algunos miembros de la comunidad rural a aceptar injerencias en la forma en que se debían gestionar los recursos. Dicho de otra forma, la pérdida del control sobre la forma de administrar el producto de su trabajo significaba, para muchos campesinos, perder el estímulo necesario para realizar dicho trabajo, puesto que, como señala Susan Harding, en los casos en que el racionamiento de alimentos y bienes era total se "eliminaba toda una esfera de decisiones sobre el consumo que eran capitales en la realidad social y el significado personal de la casa». ${ }^{57}$ Además, los casos individuales reflejan un panorama complejo, no reductible al enfrentamiento CNT-UGT (esta última, con una implantación bastante inferior a la de la CNT en la zona oriental aragonesa). Está claro que la conflictividad, en muchos casos, se canalizó a través de la identificación de los pro-

56 Los procesos colectivizadores llevados a cabo en la franja oriental de la región aragonesa están minuciosamente descritos en la monografía de Julián Casanova, Anarquismo y revolución..., op. cit. Ver también Graham Kelsey, Anarcosindicalismo y Estado en Aragón. 1930-1938. Fundación Salvador Seguí-Institución Fernando el Católico, 1994. En algunos casos, como en Graus (Huesca), la colectividad fue organizada por militantes de la UGT. En cuanto a los antecedentes de la Colectividad de Mas de las Matas durante la República, ver Macario Royo, Cómo implantamos el comunismo libertario en Mas de las Matas (Bajo Aragón). Iniciales, Barcelona, 1934.

57 Susan Harding, «Rehacer Ibieca...», op. cit., p. 68. 
tagonistas con su pertenencia a uno $\mathrm{u}$ otro sindicato, pero lo que queremos resaltar es que la política fue en muchos casos el canal a través del cual se manifestaron antiguas rivalidades entre vecinos o la confrontación entre vecinos de la localidad y elementos llegados del «exterior»: en concreto, los milicianos procedentes de Cataluña, que organizaron la vida económica y política de la comunidad.

Citaremos solamente algunos ejemplos de la provincia de Teruel, en la que la conflictividad surgida a raíz de las colectivizaciones se vivió de forma más intensa. En Oliete, en mayo de 1937 se produjo un conflicto debido a la ocultación de unas reses, "con grave perjuicio para la Colectividad», por parte de unos individuos del pueblo, lo que provocó serios incidentes entre estos individuos y allegados suyos, por una parte, y miembros del Consejo municipal por otra. En Alcalá de la Selva, en julio de 1937 un mediero amenazó a miembros del Consejo municipal que fueron a exigirle que dejase de labrar las tierras porque pertenecían a la Colectividad; los trató de «ladrones» y «marranos» y les amenazó con una dalla. En el informe de uno de los testigos, miembro del Consejo municipal, el labriego es calificado de "piltrafa analfabeto hecha del capitalismo burgués que teníamos antes del 19 de julio». Sin embargo, al parecer, este campesino había dado previamente su acuerdo para ceder sus tierras. En Alcorisa, el 10 de octubre de 1937 fue presentada una denuncia por parte de varias mujeres (una de las cuales se autocalificaba de «republicana socialista») acerca de actos cometidos por elementos de la CNT y la FAI (asesinatos y robos), ayudados por miembros de la localidad; añadían que en el pueblo se habían quedado solos niños, mujeres y ancianos con «los descontrolados de los Comités», y una de las mujeres llegó a escribir directamente a Indalecio Prieto (a la sazón ministro de Defensa). ${ }^{58}$

Un ejemplo significativo de la conflictividad en el seno de las colectividades, que no es sólo de signo político, como vemos, es el que se produjo en Mosqueruela el 27 de abril de 1937, cuando fueron asesinados tres miembros de la Colectividad de Mosqueruela por un grupo de masoveros que se sentían extorsionados por su actuación. El motivo fue la disconformidad con la colectividad: "[...] eran todos masoveros, procedentes del trabajo a medias, y que al huir los dueños, elementos fascistas, de acuerdo

58 AHN, Causa General, caja 2, legajo 1421. 
con la disposición del 7 de octubre de 1936 sobre la tierra, se crelleron [sic] con derecho a ellas, y al interpretar de modo distinto, los defensores de la colectividad, por entender que no podían beneficiarse solo y exclusivamente los masoberos [sic] ya que éstos habían sido siempre elementos de derechas mientras los hombres de izquierdas se encontraban conque [sic], a ellos no llegaba ningún veneficio [sic], surgió la natural tirantez, que dieron por resultado los hechos que costaron la vida a 3 miembros del Consejo municipal de Mosqueruela». Los asesinados fueron Antonio Bella, Victoriano Montero y Pablo Alcón, con los cuales, al parecer, ya habían surgido problemas anteriormente; Antonio Bella había recibido la siguiente carta anónima, que reproducimos textualmente:

Compañero Bella te pongo letra para decirte que sois unos ladrones que estais tragando los perniles y [ilegible] bebiendoros el bino y los pobres trabajadores matandolos de anbre pero os [ilegible] para pocos días que esa mujer que tienes en tu casa es una mala puta que sois todos los del Comite unos ladrones que un forastero oy a benido aqui atemorizar al pueblo estais tratando de fascista y los fascistas sois bosotros y os digo que sois unos ladrones estais sonsacando las casas y las buestras las llenais pero os baldra para poco que os cortan la cabeza y pueda ser que no tarden. ${ }^{59}$

Lo más interesante de este caso, razón por la que nos hemos detenido tanto en su descripción, es que al menos dos de los detenidos por su participación en los hechos, Víctor Salvador Salvador y Narciso Bayot, serán acusados durante la época de auge de la guerrilla de tener relaciones con ésta; Narciso Bayot será detenido en 1948 y Víctor Salvador morirá en 1950 a manos de la guardia civil, que le aplicará la «ley de fugas». ${ }^{60}$ Estos mismos masoveros que fueron calificados por el comité de «elementos de derechas», serán más adelante acusados de «izquierdistas» por las autoridades franquistas. Es cierto que la acusación de «fascista» era común en este tipo de conflictos, pero no lo es menos que lo que resalta en la actitud de dichos masoveros es la defensa de unos determinados intereses contra poderes impuestos desde el exterior, vengan éstos de donde vengan.

Para ahondar más profundamente, desde una perspectiva antropológica, en la forma en que se vivieron los procesos colectivizadores por

59 AHN, Causa General, caja 2, legajo 1430.

60 AHPT, sección Gobierno Civil, caja 1130, carpeta 2 (Narciso Bayot), y caja 1031, carpeta 19 (Víctor Salvador). 
parte de los campesinos no politizados en el nivel local, los testimonios orales representan una fuente muy rica y nos proporcionan numerosos ejemplos de las tensiones vividas en el seno de las comunidades. Una mujer de Fortanete (Teruel) relata la imposición de la colectivización a los vecinos de la localidad, cómo las relaciones personales influyeron en el funcionamiento de ésta y las consecuencias que tuvo el hecho de haber sido una población colectivizada en la posterior represión franquista en Fortanete. Su testimonio es el de una persona que vive la ola de violencia que acompañó a la guerra civil y sus consecuencias como algo innecesario y brutal:

[...] claro, debieron de obligar porque mi madre que tenía todos los críos pequeños tenía que ir a comprar a la colectividad, y le daban lo que querían. [...] Y después, cuando vino la "retortera», pues unos cuantos sinvergüenzas que aprovecharon la ocasión. A cortar el pelo, a hacer la burla... tampoco es eso. ¿Me entiendes? [...] Y les hicieron la vida imposible también. Que tampoco es eso. [...] Todas las que se habían ido del pueblo, a quitarles el pelo. [...] Pues es que aquí se fue mucha gente a la parte de Valencia, porque eso era la zona roja. Y entonces, toda la gente de izquierdas se recorrió... hacia la zona roja, claro. Y después cuando ya se terminó pues todo el mundo volvió a sus casas, pues los que había en el pueblo que estaban de «mandemases» de la derecha, pues a cortarles el pelo a todos los que estaban de parte de las izquierdas. Pues, ¿ves tú? Eso está mal hecho. Yo, es que pienso que se meten... que se hacen cosas mal hechas en todos los sitios y de todas las maneras. [...] Porque cuando los de izquierdas mandaron aquí, hicieron barbaridades algunos; algunos, no todos... hicieron barbaridades de matar gente e hicieron barbaridades. Pero es que, cuando se volvió la tortilla, pues volvió a pasar lo mismo [...] también fueron a parar a la cárcel unos cuantos que no habían hecho nada [...] a la cárcel fueron muchos que ya nunca volvieron a casa. ${ }^{61}$

Nos hemos extendido acerca de estos acontecimientos de ámbito local para mostrar cómo, además del enfrentamiento primordial que dividió a los aragoneses en partidarios y opositores a la sublevación militar, en «fascistas» $y$ «antifascistas», se dieron una serie de conflictos no explicables únicamente con estos parámetros, sino como síntomas de una conflictividad local que la situación de crisis de autoridad que caracterizó a la guerra civil exacerbó y llevó a su resolución de forma violenta. Aquí se manifiesta, pues, esta conflictividad de origen campesino, relacionada con la propiedad y el uso de la tierra, a la que aludíamos en un capítulo anterior.

61 Entrevista, informante anónima. Fortanete, 21 de julio de 1997. 
Bajo el rechazo por parte de algunos campesinos aragoneses al orden establecido por los anarquistas latía la oposición a la injerencia externa en los modos de vida y organización social de la comunidad rural: «en Aragón, donde la libertad individual y la autonomía de la casa iban mezcladas, la tensión entre los dos valores era poderosamente desilusionante porque el orden colectivista en realidad disolvía la casa como unidad de toma de decisiones sobre la producción, la distribución y el consumo». ${ }^{62} \mathrm{Y}$, por otra parte, las condiciones externas en las que se desarrollaron las colectividades (la guerra, que subordinaba el funcionamiento de la economía a las necesidades bélicas, y la esperanza puesta por los campesinos en unas soluciones a sus problemas concretos que no llegaban a materializarse) influyeron de forma decisiva en el conflicto entre colectivistas e «individualistas", defensores de las unidades domésticas campesinas. ${ }^{63}$

Como veremos más adelante, algunos de estos conflictos, que afectaban a la libre disposición del campesinado para gestionar el producto de su trabajo o que revelan viejas tensiones sociales exacerbadas por los acontecimientos producidos durante la guerra y la revolución, se reprodujeron varios años después y en una coyuntura completamente distinta: con el régimen franquista en el poder y la zona convulsionada por la lucha guerrillera, pues las localidades turolenses que hemos citado fueron escenario posteriormente de la acción de los guerrilleros.

En la provincia de Huesca la conflictividad campesina durante la República había sido tradicionalmente canalizada por la CNT, la organización obrera mayoritaria en la provincia, y estaba generalmente relacionada con la cuestión de los comunales. ${ }^{64}$ En la franja oriental de la pro-

62 Susan Harding, Rehacer Ibieca..., op. cit., p. 72.

63 Julián Casanova, «Sociedad rural, movimientos campesinos y colectivizaciones. Reflexiones para un debate», en Julián Casanova (comp.), El sueño igualitario: campesinado y colectivizaciones en la España republicana, 1936-1939. Institución Fernando el Católico, Zaragoza, pp. 7-15.

64 La CNT predominaba en Alcalá de Gurrea, Almudévar, Huesca, Vicién, parte de la peña de Riglos y Ayerbe, que eran los términos municipales con mayor concentración de la riqueza rústica, mientras que encontramos a la UGT/FNTT en Jaca, Ansó, Echo, Bailo, Santa Cruz de la Serós, Puente la Reina, Ayerbe, Loarre y Biscarrués. También se detecta una pequeña presencia del PCE en 1936 en Jaca, Biescas, Sabiñánigo y Barbenuta. Pilar Salomón, "La defensa del orden social: fascismo y religión en Huesca», en Julián Casanova y otros, El pasado oculto. Fascismo y violencia en aragón (1936-1939). Siglo XXI, Madrid, 1992, pp. 127-165. 
vincia, dicha cuestión se solventó de modo tajante, mediante la colectivización de las tierras, a instancias de las columnas anarquistas y de los comités revolucionarios que se crearon en cada localidad por iniciativa, la mayor parte de las veces, de los mandos militares republicanos. Este fenómeno reviste especial importancia en las comarcas de la Litera, Sobrarbe y Ribargorza, zonas que posteriormente concentrarán casi exclusivamente la actividad guerillera de la provincia. Como puede apreciarse, el fenómeno se dio tanto en la provincia de Huesca como en la de Teruel: las zonas de mayor actividad de la guerrilla, en las que ésta encontró más apoyo por parte de la población, fueron aquellas en las que se llevó a cabo la experiencia colectivizadora, hecho que responde a una serie de factores que serán analizados más adelante. En cambio, la guerrilla no logró arraigar en la provincia de Zaragoza, a pesar de que también quedó partida en dos por el frente y de que en ella se encuentra Caspe, sede del Consejo de Aragón, así como poblaciones de fuerte tradición sindical, como Mequinenza o Sástago. ${ }^{65}$ El paisaje zaragozano, principalmente el de la franja oriental, es un paisaje llano y de escasa vegetación, fácilmente controlable por una fuerza militar, y no ofrece refugios aptos para ocultar grupos de disidentes. Las únicas zonas montañosas, propicias para la acción guerrillera, se localizan en la parte occidental de la provincia, dominada desde 1936 por el ejército franquista. Se trata de un dato de importancia, pues, como se verá más adelante, el paisaje influyó de forma determinante en el establecimiento de núcleos guerrilleros. La provincia de Zaragoza quedó, en lo que a la guerrilla se refiere, como zona de paso.

La fuerte represión a la que fue sometida desde 1936 la zona occidental es la principal razón que explica la posterior ausencia de movilización guerrillera, a pesar de que, como indican las historiadoras Julita Cifuentes y Pilar Maluenda, la provincia de Zaragoza «difería en cuanto a estructura de propiedad y su grado de afiliación destacaba y la acercaba al de las áreas latifundistas del sur. En definitiva, era un territorio penetrado por la República, que no había permanecido impermeable a las posibilidades de participación, reivindicación y cambio ofrecidas por este régimen». En la misma provincia, la comarca de las Cinco Villas (Ejea y

65 Ver José Luis Ledesma, "Asalto al pasado y revolución: la represión republicana en la provincia de Zaragoza durante la guerra civil», Rolde. Revista de cultura aragonesa, n. ${ }^{\circ} 88-89$, abril-septiembre de 1999, pp. 5-19. 
Sos), zona fuertemente politizada y con un alto grado de participación sindical, sobre todo de signo socialista, opuso una notable resistencia a la sublevación, y en ella se produjo el fenómeno de los «huidos», fracasado debido a la importante represión ejercida por las "columnas de castigo" que el régimen envió para aplastarlo. Posteriormente, fue también esta comarca la que albergó el único núcleo guerrillero de importancia de la provincia. $^{66}$

En la zona occidental aragonesa, el proceso seguido hasta 1938 es completamente distinto del de la oriental. Como desde el comienzo de la sublevación quedó en manos del ejército franquista, se establecieron desde un primer momento las estructuras del «Nuevo Estado», y los elementos desafectos que no lograron huir hacia la zona republicana fueron sometidos a una represión implacable. Tanto es así que no quedaron huecos para la disidencia, y durante la posguerra las organizaciones izquierdistas, completamente desarticuladas, tardarían largo tiempo en rehacerse. Al tratarse de una zona de retaguardia próxima al frente, la represión fue especialmente dura, y tomaría además como pretexto la represión que a su vez se llevaba a cabo en la zona republicana contra los individuos derechistas y contra el clero.

Las colectividades de la franja oriental aragonesa sufrieron los efectos de una doble represión. A raíz de la disolución del Consejo de Aragón, en agosto de 1937, las tropas comunistas de la 11. a División, a las órdenes de Enrique Líster, se encargaron de reconducir la política colectivista y encarcelaron, o incluso fusilaron, a los principales responsables de las colectividades, sobre todo anarquistas, que no escaparon hacia la zona del frente. ${ }^{67}$ Y a partir de 1938, el avance de las fuerzas franquistas sobre las poblaciones del este aragonés se vería acompañada por un proceso represivo de

66 Julita Cifuentes y Pilar Maluenda, El asalto a la República: los orígenes del franquismo en Zaragoza (1936-39). Institución Fernando el Católico, Zaragoza, 1995, pp. 136142, cita en p. 136.

67 No era raro entre los ugetistas ser a la vez miembros o simpatizantes del Partido Comunista, que no poseía un sindicato propio. Ver Collectif Equipo Juvenil Confederal, La collectivité de Calanda. 1936-1938. La révolution sociale dans un village aragonais. Éditions CNT Région Parisienne, 1997. Confederación Nacional del Trabajo de España. Regional de Aragón, Rioja y Navarra, Realizaciones revolucionarias y estructuras colectivistas de la Comarcal de Monzón (Huesca). Con notas sobre la represión comunista. Ediciones Cultura y Acción, Monzón, 1977. 
enormes dimensiones y, sobre todo, de tremenda crueldad. Los protagonistas de esta represión, extremo confirmado por las fuentes orales, fueron no sólo las propias tropas franquistas, sino también, ocupando un lugar destacado, los derechistas de cada población, que señalaron con el dedo a los vecinos y vecinas que consideraban culpables de la situación de «anarquía» y de la violencia contra los simpatizantes de la sublevación producida durante el dominio de los republicanos. En ausencia de muchos de los hombres de estas poblaciones, huidos a las zonas aún controladas por los gubernamentales, movilizados, prisioneros o muertos, serían sus mujeres el objeto de tales represalias. A ellas se las sometió a un tipo de represión específica, que incluía elementos de humillación como el rapado de pelo, la ingestión de aceite de ricino, la obligación de barrer la iglesia... ${ }^{68}$

En algunas poblaciones la represión adquirió dimensiones especialmente brutales, como en el caso de Calanda, donde incluso varios falangistas fueron detenidos por la escandalosa dimensión de los hechos represivos en los que tomaron parte. Según el testimonio oral de una calandina, hija de una de las mujeres detenidas, «antes de ir a la cárcel les hacían barrer todo el pueblo y llevar la escoba. Mi madre y otras tenían la cuesta del convento hasta el cuartel de la guardia civil, y los fascistas salían a

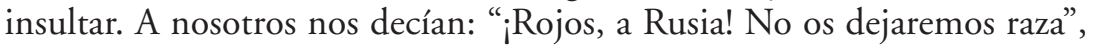
y [a] Carmen Zapater y mi madre les hacían barrer la secretaría. [Fueron detenidas] Dña. Carmen Vigos, maestra nacional, motivo: bordar la bandera republicana que el Gobierno legalmente constituido le mandó; mi tía Francisca Galindo Asensio, mi madre, María Teresa (apodo Pajalarga), María (apodo Bocapreta), Francisca Borraz mujer del Paco (Damián), la tía Concha, la Basilia, todas por ser familia de izquierdas...». ${ }^{69}$ Esta misma informante relata los terribles crímenes cometidos el 29 de marzo de 1938, los llamados "sucesos de Calanda", durante los cuales murieron, según ella, unas sesenta personas, aunque las fuentes oficiales hablan de

68 Esta represión diferencial desde el punto de vista del género ha sido señalada, entre otros, por Yannick Ripa, «Armes d'homme contre femmes désarmées: de la dimension sexuée de la violence dans la guerre civile espagnole», en Cécile Dauphin y Arlette Farge (dirs.), De la violence et des femmes. Albin Michel, París, 1997, pp. 131-145. Y la encontramos en diferentes contextos políticos e históricos; es la misma represión a la que se somete a las mujeres acusadas de colaboración con los nazis por los guerrilleros del maquis francés.

69 María Sanz, 11-2-98, Béziers. Testimonio escrito. Transcrito con correcciones ortográficas y de puntuación. 
cuarenta: «Primero en Calanda nos fuimos a la huerta por miedo a los bombardeos. Hubo muchos muertos y de allí muchos comenzaron el éxodo hacia Cataluña y otros lugares. Cuando regresaban, llegaron los crímenes del día del Milagro [...] mataron 4 matrimonios, 29 personas el mismo día, entre todos unas 60 personas». Una de ellas era una mujer embarazada, a la que, según relata la informante, «le saltaron en el vientre y le saltaron el niño", hecho relatado también en el informe de los hechos elaborado por el inspector provincial de FET-JONS en Teruel. ${ }^{70}$ Esta brutalidad se explica, como indica Ángela Cenarro, si tenemos en cuenta que «Calanda fue una de las poblaciones más duramente castigadas por el terror de las milicias, pues así se deduce del recuento de sus 108 asesinados, que equivalen al 2,5 por ciento del total de la población, uno de los porcentajes más altos de toda la provincia». ${ }^{71}$ Estas poblaciones que habían permanecido durante casi dos años en zona republicana fueron objeto de una represión implacable, destinada a borrar cualquier vestigio de la anterior "dominación roja» y a vengar las afrentas sufridas por los derechistas y el clero.

Con el fin de la guerra, comenzó un proceso de «normalización» de la vida política y administrativa de la región aragonesa. Si es que puede hablarse en estos términos, puesto que una gran parte de la población era víctima de represalias de una u otra forma, y otra parte no desdeñable había

70 Ib. El dato del inspector, en Ángela Cenarro, «El triunfo de la reacción: fascistas y conservadores en Teruel», en Julián Casanova y otros, El pasado oculto..,. op. cit., pp. 171217, cita en p. 187.

71 Ángela Cenarro, «El triunfo de la reacción...», op. cit., p. 187. Miguel Ángel Ruiz Carnicer hace alusión también a estos hechos y a la dimensión de género que revistió la represión en Calanda, "donde a principios de 1940 se practican en el Ayuntamiento violaciones y "bacanales" como parte de una gran violencia sobre mujeres "izquierdistas"; también desde la alcaldía se planifican una serie de asesinatos a manos de los falangistas locales, al margen de la autoridad militar». Miguel Ángel Ruiz Carnicer, «Poder político y respuesta social en el Bajo Aragón turolense en el primer franquismo", en Pedro Rújula (coord.), Entre el orden de los propietarios y los sueños de rebeldia: el Bajo Aragón y el Maestrazgo en el siglo XX. Grupo de Estudios Masinos, Mas de las Matas, 1997, pp. 89-108, cita en p. 91. Asimismo, Michael Richards se refiere a la represión dirigida contra las mujeres de los republicanos, represión que tiene una dimensión «moral» desde el punto de vista del régimen: "Las mujeres eran consideradas culpables de no haber mantenido una vigilancia moral sobre sus compañeros. De hecho, ser la esposa de un "marxista" era razón suficiente para ser ejecutada». Michael Richards, "Guerra civil, violencia y la construcción del franquismo", en Paul Preston (ed.), La República asediada. Hostilidad internacional y conflictos internos durante la Guerra Civil. Península, Barcelona, 1999, pp. 201-238, cita en p. 232. 
partido camino del exilio o había desaparecido en el transcurso de la guerra o las acciones represivas de ambos bandos. La represión continuó a un ritmo que no descendería hasta años después de finalizada la contienda, la población reclusa abarrotaba las cárceles, se crearon campos de concentración para prisioneros de guerra y se formaron numerosos batallones de trabajo compuestos también por prisioneros republicanos. La vuelta de algunos republicanos a sus poblaciones de origen, unos procedentes de los campos de concentración y otros creyendo que, una vez terminada la guerra, las cosas volverían a la normalidad, pues no habían tomado parte en "hechos de sangre», fue otro factor de tensión social: sus vecinos de signo político contrario los recibieron con desconfianza, odio y deseo de venganza, y dieron rienda suelta a una violencia latente de la cual fueron víctimas los vencidos a manos de sus propios vecinos, que llevaron a cabo acciones de revancha más allá de la represión «legal».

Hay, sin embargo, casos aislados en los que la situación fue la inversa: algunos republicanos que volvieron a sus lugares de origen fueron defendidos por sus convecinos alegando que actuaron a su favor durante el «dominio rojo». Un caso significativo es el de Pedro Campón Rodríguez, que fue miembro del Comité de Guerra en la Columna Durruti, secretario del propio Durruti y redactor del periódico El Frente. El 7 de noviembre de 1940 se presentó en Pina de Ebro, procedente de Barcelona, su mujer, Caridad Martínez Hernández, que seis meses antes había vuelto de Francia. Su marido, que aún estaba en un campo de concentración francés, le había dado unos valores que él había recibido en esta localidad «en agradecimiento a las vidas que había salvado mientras estuvo enrolado en las filas marxistas, y que era su deseo llegasen a poder de su legítimo propietario». Según las declaraciones de algunos vecinos, que estuvieron detenidos durante el «dominio rojo», Pedro Campón intervino a favor de ellos, gracias a lo cual fueron puestos en libertad. Pero el informe continúa diciendo que, «si bien fue alguna vez compasivo y humanitario para con algunos detenidos parece ser que está considerado como responsable de los 21 fusilamientos que se cometieron en esta localidad». Finalmente, los valores y Caridad Martínez fueron puestos a disposición del fiscal de la Causa General de Aragón. ${ }^{72}$

72 Archivo del Gobierno Civil de Zaragoza, sección Asuntos Gubernativos, caja 103, carpeta 12. Una vez más, vemos cómo, en ausencia del marido, es su mujer (de la cual no sabemos que ejerciera función alguna durante la guerra) la que es detenida en su lugar. 
La importancia de señalar estos hechos represivos, anteriores o posteriores al final de la guerra y de los cuales Calanda es un ejemplo paradigmático (y uno de los que más fuertemente ha marcado la memoria de la población), reside, por una parte, en mostrar la dimensión local de la represión, es decir, cómo, además de responder a un proceso inducido por elementos externos (las tropas franquistas), fue protagonizado también por personas pertenecientes a la comunidad, lo cual tendría indudables repercusiones en la convivencia futura y en el desarrollo de las relaciones locales. Y, por otra parte, nos parece importante resaltar el papel de las mujeres como chivos expiatorios, castigadas por las acciones cometidas por los hombres ausentes, más que por las propias, un papel que volverían a representar más adelante, durante la época de la guerrilla. Tratamos, pues, de rastrear el origen de una violencia que sacudiría fuertemente algunas zonas aragonesas a partir de 1944, cuando la presencia de los guerrilleros antifranquistas reavivase una conflictividad que ya se encontraba latente en dichas zonas.

En cuanto al proceso de construcción de las estructuras políticas y administrativas del «Nuevo Estado» franquista en el medio rural, que es el que nos interesa, se trata de un proceso minuciosamente explicado por Ángela Cenarro. En su análisis pone de manifiesto que la clase dirigente estaba lejos de alcanzar el grado de consenso y monolitismo que el régimen pretendía transmitir a la población, y señala la rivalidad existente entre las viejas jerarquías locales, de carácter conservador y católico, que pretendían restaurar las antiguas redes del poder caciquil, y los «hombres nuevos» procedentes de las filas de Falange y a la vez pertenecientes a la elite económica y social, o al menos fuertemente conectados con ella; en sus palabras, «FET-JONS se convirtió en una plataforma que permitió la reproducción de las tradicionales rivalidades locales, aquellas que habían dividido a estas pequeñas sociedades tal vez durante generaciones». En suma, entre los «derechistas» de cada localidad había una heterogeneidad que correspondía a viejas luchas por el poder local, enfrentamientos entre los miembros de la elite que aprovecharon la nueva coyuntura, en la cual otros actores sociales habían sido violentamente apartados de la escena, para pugnar por alcanzar una parcela de poder o recuperar el que ejercían antaño, antes de que la Segunda República abriera las puertas a la democratización de la sociedad y la participación de las masas en la política. Sin embargo, como apunta Cenarro, no hay que sobrevalorar esta división en 
el seno de las elites: "La animadversión hacia los "caciques", una constante en el discurso falangista, no debe ocultar la realidad de que el Partido facilitó la recuperación del poder local por aquellos grupos sociales que lo habían ejercido desde tiempo atrás». ${ }^{73}$

Pero, en suma, nos interesaba señalar estas pugnas en la clase dirigente (que a nivel local se reflejan muchas veces en la rivalidad entre el alcalde y el jefe local de Falange, hasta la unificación de ambos cargos) porque significan una nueva línea de fractura en la sociedad aragonesa de la inmediata posguerra. Como decía el delegado provincial de Información e Investigación de Teruel en un informe sin fechar, «no sólo hay un bando de los que siguen siendo rojos hasta la médula y de los nacionales, sino que lo lamentable es que entre éstos existan disidencias». ${ }^{74} \mathrm{Y}$ algo muy semejante era señalado por el delegado de administraciones locales enviado a Huesca en 1939; por ejemplo, refiriéndose a la población de Laperdiguera, afirmaba que «no ha desaparecido la política local de partido o mejor dicho de personas, y continúan formando un grupito cada una de las autoridades (jefe local de Falange y alcalde) y tengo el concepto de que todo preocupa más que las obligaciones del cargo». ${ }^{75}$ Además de estas disensiones, la fuerza de los intereses de las elites locales se muestra en la designación de alcaldes, elegidos entre aquellos que ostentaban el poder económico de la localidad e incluso entre antiguos "caciques», sin tener en cuenta su idoneidad para el cargo. Cuando esto no era así, la labor del alcalde podía incluso ser obstruida por el cacique de turno. Es significativo el informe elaborado por el inspector sobre los partidos judiciales de Benabarre y Boltaña, en el cual se reseña, acerca de los alcaldes, que «en su casi totalidad son labradores, legos en el conocimiento de las leyes y en las obligaciones y derechos que les competen en el ejercicio de sus cargos». En Castelflorite la Administración local se encontraba abandonada: «el alcalde, [es] buena persona, muy afecta al régimen y perseguida por los rojos, pero des-

73 Ángela Cenarro, Cruzados..., op. cit., p. 147.

$74 \mathrm{Ib}$.

75 Informe breve de las condiciones que reúnen las comisiones gestoras de los Ayuntamientos que se expresan y especialmente los sres. Alcaldes según los antecedentes adquiridos por el que suscribe (s.f.). AHPH, sección Gobierno Civil, Admón. local, 2215. Encarna Nicolás señala también la importancia de estudiar la composición e instauración de los poderes locales en el primer franquismo, para analizar cómo se extiende el poder del Estado a nivel local. Encarna Nicolás, "Los poderes locales...», op. cit. 
cuidado en sus obligaciones oficiales». Algo semejante ocurría con los depositarios, de los que se señala: «[...] en general, como si no existieran. Labradores que apenas saben leer, escribir y las cuatro reglas [...] todos ellos sin fianza de ninguna clase, pero todos propietarios de suficiente número de fincas para responder de mucho mayores fondos de los que por su cargo manejan». En cuanto al enfrentamiento entre diferentes poderes locales, tenemos un ejemplo en la población altoaragonesa de Calasanz, donde se calificaba a uno de los gestores de "cacique», una denominación peyorativa común en el discurso falangista, agregando que obstruía la labor del alcalde. ${ }^{76}$

Otra manifestación de la consolidación del régimen a nivel local es la organización de la vida material de los ciudadanos, bajo la forma de unas estructuras de control económico orientadas a controlar los recursos mediante la imposición de una política económica centralizada y autárquica. La imposición de esta política generó fuertes rechazos, no sólo por parte de los sectores menos favorecidos de la sociedad, que son los más perjudicados por dicha política y, a la vez, los que encuentran más dificultades para sustraerse a ella, sino también por parte de los representantes del poder económico: en nuestro caso, los grandes propietarios, personas en las que muchas veces confluían el poder económico y el político. Del análisis de las gestoras municipales en la provincia de Huesca extraemos la conclusión de que tras la guerra retomaron el poder local aquellos que lo ostentaban con anterioridad, los antiguos caciques y los labradores más poderosos económicamente, y algo semejante ocurrió en el resto de la región.

En cuanto a la regulación de la economía de posguerra, la creación del Servicio Nacional del Trigo en 1937 regulaba tanto el mercado como los precios de la producción cerealística; su política tendía a favorecer a las provincias cerealistas de Castilla (una forma, quizás, de premiar su apoyo

76 Informe general resumen de las visitas de inspección realizadas en diferentes pueblos de los partidos judiciales de Benabarre y Boltaña. AHPH, sección Gobierno Civil, Admón. local, 2215. La instauración y la división de los poderes locales en la provincia de Huesca es analizado con mayor profundidad en Mercedes Yusta, «Raíces profundas: conflictividad y redes de poder durante los "años de los maquis" en la provincia de Huesca, 1940-1949", comunicación leída en el II Congreso de Historia Local de Aragón. Tendencias historiográficas actuales, celebrado en Huesca los días 7 al 9 de julio de 1999, que será publicada en las actas, de próxima aparición. 
mayoritario a la sublevación), mientras que ciertas zonas de Aragón donde el cultivo del cereal no se practicaba extensivamente se vieron claramente perjudicadas. En general, los grandes productores, con capacidad para almacenar el producto, eran lo que menos se exponían a no llegar a cumplir los cupos, y a la vez los que más facilidades encontraban para practicar el estraperlo a gran escala.

Pero esta política económica se mostraría muy pronto ineficaz, y suscitó una reacción negativa tanto por parte de los grandes productores, que no declaraban parte de sus cosechas, como de las autoridades locales, que apoyaban implícitamente tal actitud, en contra del poder central. El hecho ha sido detectada por varios historiadores, como Encarna Nicolás, quien afirma que «la política autárquica con discriminación negativa en algunas regiones alentó actitudes de propietarios, empresarios, e incluso autoridades locales, en contra de las burocracias centrales, nacionales o provinciales». ${ }^{77}$ En el caso de Aragón, y no es el único, las protestas fueron incluso canalizadas en ocasiones a través de las Hermandades de Labradores y Ganaderos, controladas por los grandes propietarios, que percibían que, como señala Carlos Barciela, «los gobiernos franquistas se plantearon como objetivo fundamental la industrialización del país y a este objetivo sacrificaron otros sectores de la economía, particularmente el sector agrario». ${ }^{78} \mathrm{Y}$, por supuesto, esta política provocó el rechazo frontal de los pequeños productores, los más perjudicados por ella y, al mismo tiempo, los más controlados por las autoridades. Los inspectores de la Delegación de Abastecimientos y Transportes («los de Abastos») se convirtieron en blanco del odio de la población; algunos de los actos imputados a la guerrilla durante la segunda mitad de la década de los cuarenta tendrían como protagonistas a estos personajes. Las confrontaciones entre autoridades locales y poder central a causa del control de los recursos se exacerbaron en determinadas zonas a raíz del comienzo del conflicto guerrillero, como veremos más adelante. Los intereses locales primaban, en suma, sobre la fidelidad a las directrices económicas del régimen, que eran expresión, a fin de cuentas, de su política totalitaria y centralista, cuyo objetivo era controlar todas las parcelas de la vida del país. ${ }^{79}$

77 Encarna Nicolás, «Los poderes locales...», op. cit., p. 82.

78 Carlos Barciela, "Franquismo y corrupción económica», Historia Social, n. ${ }^{\circ} 30$, 1998, pp. 83-96.

79 Como también señalan Encarna Nicolás, "Los poderes locales...», op. cit., y Michael Richards, Un tiempo..., op. cit., en especial en el cap. 7. 
Las propias autoridades franquistas, y en especial los falangistas, eran conscientes del fracaso de esta política económica y del rechazo que provocaba en la población. Un informe de Higinio Paris Eguilaz, consejero nacional de FET y de las JONS, fechado en 1940, ponía de manifiesto los fallos de la política económica franquista, destacando el efecto psicológico que causaba en la población la escasez de productos básicos, principalmente de pan, y el acaparamiento por los campesinos de parte del trigo que producían, y lo achacaba a errores de la política de tasas, descartando el uso de la coerción para corregir tal situación en el medio rural: "Contra estos fenómenos psicológicos no se puede luchar por la fuerza. Si es fácil obligar por la coacción a los industriales, a los comerciantes e incluso a los obreros de las ciudades a que cumplan con exactitud las disposiciones gubernamentales, en cambio ningún Estado ha podido dominar al campesino con la fuerza pública en lo que se refiere a la esfera económica». De paso, el comentario del consejero refuerza las tesis de Scott ya comentadas acerca de la fuerza del campesinado a la hora de ofrecer una resistencia pasiva a los intentos de control económico del poder central. También destacaba las quejas de la población por la corrupción generalizada, una corrupción que el Estado franquista siempre toleró y que, en cierto modo, propició con una política intervencionista "poco meditada y sin tener en cuenta las relaciones que existen siempre entre causa y efecto». ${ }^{80}$

En Aragón encontramos los mismos análisis de la situación. En un informe del delegado provincial de Sindicatos de Teruel, Jesús Milián, fechado en 1947 y relativo a la alteración del orden público en la provincia a causa de la creciente actividad guerrillera, se menciona el fracaso de la política económica y se asocia con la conflictividad de la provincia, lo cual reviste especial interés para nuestro objeto de estudio, ya que pone en relación la conflictividad de la lucha armada con la problemática económica vivida en el medio rural:

La situación que se viene afrontando en los dos Consejos Provinciales del Movimiento celebrados, creada por la torpe y hasta intencionada actuación del Servicio Nacional del Trigo y de la Delegación de Abastecimientos y Transpor-

80 Informe de Higinio Paris Eguilaz, consejero nacional de FET y de las JONS, «Sobre los fallos en la política económica», 20 de septiembre de 1940, en Documentos inéditos para la historia del Generalísimo Franco. Fundación Nacional Francisco Franco, Madrid, 1992, tomo II, pp. 327-370, citas en pp. 338 y 369. La cursiva es mía. 
tes, motiva el fracaso más estrepitoso, que está cosechando el Gobierno Civil [...] Debe meditarse con absoluta y profunda atención que, unida a la actual situación, se está creando otra más peligrosa, con una base moral, pues mientras en la capital de la provincia se goza de todos los racionamientos especiales, en el resto de los pueblos se carece de ellos [...], ya que se les priva de carne y, por añadidura, se les va a suprimir el racionamiento de pan. ¿Qué significa esto?

Simplemente, significa el fracaso de una acción gubernativa y política que requiere también las medidas adecuadas, como son, si hubo mala intención y falta de competencia, la de proceder con dureza inmediatamente contra los titulares de los servicios técnicos que han provocado esta situación, y por otra parte recoger esta grave enseñanza y cargar con la responsabilidad que corresponda, pues no se puede permitir que hayamos exportado más de 500 vagones de trigo y tranquilamente digamos ahora, que no se puede dar pan.

Por la tremenda responsabilidad que se contrae por toda esta situación, y volviendo al tema del orden público, si existen escrúpulos de proceder con energía que el momento requiere, debe analizarse con detenimiento cuál es la responsabilidad obtenida ante la muerte constante de personas por la ineficacia de las medidas que se toman y por dejar nuestros pueblos a merced de los bandoleros al no tener la decisión de aplicar medidas enérgicas. ${ }^{81}$

De este informe podemos extraer conclusiones muy interesantes, pues en él confluyen varios de los puntos de la conflictividad que hemos analizado, para, posteriormente, entender la explosión de violencia que acompaña a la actuación de los guerrilleros, especialmente en la provincia de Teruel, que era además, y no por casualidad, la que atravesaba una situación económica más penosa de las tres que componen la región aragonesa. En él vemos la división entre la elite que gobierna, principalmente canalizada a través de Falange (son casi siempre falangistas los que expresan este tipo de protestas), a que aludía Ángela Cenarro; vemos, también, la conexión que desde el poder político se establece entre la intervención económica y el aumento de la conflictividad rural; y, aunque no se explicita, la relación entre la conflictividad de origen económico y el problema de la guerrilla (los «bandoleros» citados en el último párrafo). Si a esto unimos la fuerte represión sufrida por los sectores «hostiles al régimen» de la población rural, una represión que tiene su origen en la guerra civil y se recrudece con la aparición de la guerrilla, y además

81 Jesús Milián, «Situación de la provincia de Teruel en cuanto a orden público, gubernativo y organismos técnicos del Estado», 21 de mayo de 1947. Archivo de la OS, caja VPOS, notas interiores, 1942-1949. Citado en Gaudioso Sánchez Brun, «Aportaciones documentales para el estudio del maquis en la provincia de Teruel», Turia, n. ${ }^{\circ}$ 9, 1985, pp. 203-226, cita en pp. 221-222. 
las divisiones producidas o potenciadas por la guerra en el seno de las comunidades rurales aragonesas, tenemos un cuadro bastante completo de las tensiones y líneas de fractura que permitieron el establecimiento y, sobre todo, la duración en el tiempo de un movimiento de resistencia armada que, con una política, una táctica y unos hombres importados del exterior, se imbricó en esta sociedad rural convulsionada y extrajo de ella efectivos y apoyos. Tenemos, en suma, el telón de fondo en el que se desarrollará el drama.

\subsection{Al otro lado de la frontera: la contribución de los españoles a la Resistencia francesa y sus consecuencias para la lucha en el interior}

3.2.1. La Resistencia francesa y la resistencia de los españoles

La résistance des Espagnols n'a jamais commencé, c'est la continuation de la guerre d'Espagne.

(Claude Delpla)

Es difícil fechar el comienzo de la Resistencia francesa contra el régimen de Vichy y el ocupante alemán. En un sentido amplio, probablemente empezó desde el mismo momento en que se firmó el armisticio, aunque su comienzo «oficial» lo marca el conocido llamamiento del general De Gaulle a todos los franceses a través de la BBC de Londres. Ése es el momento en el que realmente empiezan a organizarse estructuras, redes y movimientos de resistencia, aunque la resistencia armada propiamente dicha, exceptuando las acciones de la OS (la organización armada creada por el PCF) tardaría aún años en dar comienzo. En realidad, la Resistencia francesa en su conjunto consistió más bien en acciones destinadas a sabotear al ocupante o a sus representantes franceses, tanto en el aspecto administrativo como en el material, así como en actos de propaganda y, sobre todo, en ocultar a personas perseguidas por las autoridades fascistas y recopilar información útil para los Aliados; además de los pequeños gestos de rebeldía manifestados por la población cotidianamente, sobre todo respecto a los ocupantes nazis y especialmente a partir de 1943. En cuanto a la resistencia armada, l'Armée secrète (la organización de resistencia interior del Ejército) había recibido órdenes de esperar sin actuar hasta que 
se produjera el desembarco aliado, y los únicos grupos que ofrecían una resistencia directa, es decir, que llevaban a cabo una guerra de guerrillas contra el ocupante, eran, en un principio, las unidades de la OS, y a partir de 1942 las unidades de guerrilleros mayoritariamente comunistas de los FTP-MOI.

La MOI (Main-d'oeuvre immigrée) era una organización creada por el PCF en 1924 para acoger y encuadrar a los inmigrantes y refugiados políticos antifascistas que comenzaban a llegar a Francia desde Italia y los países de Europa central huyendo de los regímenes fascistas instalados en sus lugares de origen; la MOI se ocupaba, sobre todo, de defender sus derechos sindicales. Este contingente de refugiados, muchos de los cuales formaban parte de los partidos comunistas de sus países de procedencia, proporcionó un elevado porcentaje de brigadistas internacionales en la guerra civil española. Un gran número de los que volvieron a Francia después de su experiencia española se implicó en la resistencia comunista, dando un nuevo objetivo y un nuevo sentido a la MOI. ${ }^{82}$ Cuando en febrero de 1942 la dirección del PCF decidió crear los FTP, sus efectivos procedían de la extinta OS y de la MOI. El primer batallón FTP-MOI se creó en París en marzo de 1942 y estaba al mando de Lisner, un antiguo brigadista. En conjunto, puede afirmarse que un gran número de los componentes de las unidades FTP-MOI eran antiguos combatientes de las Brigadas Internacionales, en particular los mandos. ${ }^{83}$

En cuanto a los exiliados españoles que habían cruzado la frontera en 1939, fueron repartidos por las autoridades francesas de la III República en campos de internamiento que se prepararon de forma precipitada para acoger la avalancha de refugiados. Estos campos se encontraban en todo el territorio francés, pero los más importantes se situaban en la zona sureste, próximos a la costa. El primero en abrirse fue el de Argelès-sur-Mer, que llegó a acoger a más de cien mil refugiados. Otros campos se hallaban en departamentos del Rosellón o de los Pirineos Atlánticos: Bram, Agde, Rivesaltes, Septfonds, Gurs, Vernet, Rieucros... En estos campos, los españoles eran agrupados por orígenes provinciales o formación militar. Desde nal.

82 Rebautizada por algunos de sus miembros como Movimiento Obrero Internacio-

83 Dominique Venner, Histoire critique..., op. cit., pp. 230-238. 
la primavera de 1939 se elaboraron además listas de «activistas peligrosos», individuos que recibían un tratamiento especial: eran recluidos en campos de castigo, como el castillo de Collioure (utilizado como prisión), Rieucros (para mujeres), Vernet o Gurs, o los terribles campos disciplinarios del norte de África, en Túnez y sobre todo Argelia: Djelfa, Meridja, Moraud, Ben Chicao para las mujeres...

Un sector de la población francesa, el situado más a la derecha y también una parte importante de las poblaciones afectadas por la proximidad de los campos, protestarán por la presencia en suelo francés de los «rojos españoles», acusando a los hombres de subversivos peligrosos y a las mujeres de atentar contra la moralidad de las francesas. En los periódicos de la derecha francesa más intransigente, como L'Action Française o Gringoire, periodistas como Léon Daudet y Henri Béraud clamaban contra la invasión de Francia por las hordas del «Frente Crapular» (nombre que daban al Frente Popular español), y se preguntaban si Francia iba a convertirse en el vertedero de Europa. A pesar de todo, también hubo numerosas y honrosas excepciones a esta actitud: varios refugiados dan cuenta en sus escritos o testimonios orales de la solidaridad del pueblo francés ante los exiliados, a los que ofrecían comida y ayuda material, y desde fecha muy temprana se organizaron comités de ayuda a los refugiados en los que participaban intelectuales, políticos progresistas y grupos religiosos, como los cuáqueros americanos. Entre los intelectuales no sólo se encontraban hombres de izquierdas, como André Malraux o Jean Cassou, sino también católicos, como François Mauriac o Georges Bernanos. ${ }^{84}$ Asimismo, se crearon comisiones que visitaban los campos para asegurarse de que los refugiados disfrutaban de unas condiciones de vida aceptables. La mayoría de los campos, sin embargo, no pasaron el examen. El propio campo de Argelès, antes de ser organizado, no disponía de ninguna instalación

84 Malraux había participado en la guerra civil española, encuadrado en las Brigadas Internacionales; Jean Cassou era de origen español por parte de madre. Durante la ocupación alemana, ambos participarán en la Resistencia francesa y mantuvieron un estrecho contacto con los españoles; tras la Liberación, Jean Cassou, como prefecto de Toulouse y comisario de la República en la región de Mediodía-Pirineos, dará toda clase de facilidades a los exiliados españoles y a la organización de origen comunista Unión Nacional Española, de la que hablaremos más adelante. Georges Bernanos escribió una obra, Los grandes cementerios bajo la luna, publicada en castellano ya en 1939 en la editorial Zig-Zag de Santiago de Chile, en la que da cuenta del horror de la represión franquista. 
higiénica ni de agua corriente; en un primer momento, ni siquiera había barracas. En la confusión inicial, hombres y mujeres estaban mezclados, y, un detalle que muchas mujeres recuerdan con horror, se encontraban todos en la playa al hacer sus necesidades, sin la más mínima intimidad. En el campo reinaba una promiscuidad impuesta que fue denunciada por los propios internos e internas, contradiciendo los temores de algunos lugareños que veían en esas mujeres españolas un peligro para la moral. El supuesto "peligro para la moral» estaba en las propias condiciones del campo, un campo extraordinariamente masificado donde no tardó en organizarse un auténtico «barrio chino» (llamado así por los propios internos), en el que se compraba y vendía de todo, y vigilado por soldados senegaleses y marroquíes que recordaban a los españoles las temidas tropas moras de Franco. ${ }^{85}$ En realidad, eran los propios internados e internadas quienes hacían mínimamente habitables los campos de concentración, y los responsables de su organización interna. En los campos, además, se realizaban actividades de tipo cultural; la presencia de intelectuales, maestros y profesores universitarios contribuyó a hacer de los campos un catalizador de la identidad republicana. Se impartían clases, se editaban periódicos, se celebraban reuniones políticas, se intentaba mantener vivo por todos los medios el espíritu de la República. Este fenómeno es común a los campos de hombres y a los de mujeres. Tras los primeros momentos de confusión, éstas fueron recluidas en recintos diferentes junto a los niños menores de doce años, y trataron por todos los medios de mantener alta su moral y dignidad en medio de las más duras condiciones materiales.

La organización de los campos era en gran medida controlada por los propios refugiados, lo que permitió el desarrollo de una importante actividad política, y de paso la reproducción de algunos conflictos que formaron parte del bagaje que los españoles llevaron al exilio. Por ejemplo, anarquistas y comunistas se organizaron apartados unos de otros, aunque algunos internos hablan de «enlaces» entre ambas formaciones políticas, y en medios

85 Asile et travail aux Républicains espagnols. Pour la liquidation des camps de concentration. Résolutions de la Conférence Française d'aide aux Réfugiés espagnols. 10 et 11 juin 1939. Comité Français de coordination pour l'aide aux populations civiles de l'Espagne républicaine, París; Deux missions internationales visitent les camps de réfugiés espagnols (mai 1939). Comité International de Coordination et d'Information pour l'aide à l'Espagne Républicaine, París; y Conférence Internationale d'aide aux réfugiés espagnols. París, 1939. Entrevista, Amador Martínez. París, 27 de enero de 1998. 
anarquistas se acusará a los comunistas de hacerse con los puestos de responsabilidad de intendencia, correos o enfermería - por tanto, con el control de los campos-, y de llevar a cabo actuaciones irregulares, como censurar la prensa libertaria e impedir que llegase al interior de los campos. ${ }^{86}$

Ante el desbordamiento y la flagrante falta de condiciones de los campos, el Gobierno francés buscará soluciones para desalojarlos lo antes posible. Las soluciones que se ofrecieron a los refugiados consistieron en repatriarse a la España franquista, enrolarse en la Legión Extranjera o formar parte de las Compañías de Trabajadores Extranjeros (CTE), que se formaron en virtud de un decreto de 12 de abril de 1939, pensadas sobre todo para los refugiados españoles: el encuadramiento en ellas era obligatorio para los refugiados o apátridas de sexo masculino (estatuto que afectaba a los españoles) y con una edad comprendida entre los veinte y los cuarenta y ocho años. En las compañías de extranjeros la presencia de españoles será mayoritaria (según Geneviève Dreyfus-Armand, entre cincuenta mil y sesenta mil). En cuanto a las mujeres, muchas permanecieron en los campos, otras en centros de acogida y algunas, las más afortunadas, fueron recogidas en casas particulares o encontraron un trabajo (generalmente, como empleadas de hogar). La experiencia de las mujeres en los campos fue especialmente dura; muchas de ellas eran mujeres no politizadas, acostumbradas a depender de los miembros masculinos de su familia, de los cuales se veían ahora bruscamente separadas. En los testimonios de mujeres internadas se trasluce cómo su preocupación prioritaria era encontrar a los familiares dispersos, así como el cuidado de los niños que habían quedado a su cargo. Muchas de estas mujeres dieron a luz en los campos, en condiciones infrahumanas. Y, a pesar de la preocupación colectiva por el cuidado de los niños (en los campos femeninos, las mujeres más politizadas o más conscientes organizaron redes de solidaridad y ayuda mutua, uno de cuyos objetivos era proporcionar a las madres alimentos para las criaturas y medios para mantener su higiene), la mortalidad infantil fue altísima. ${ }^{87}$

86 Jean-Claude Villegas, Plages d'exil. Les camps de réfugiés espagnols en France-1939. BDIC, Nanterre, 1989.

87 Un testimonio de la entrada de las mujeres en los campos, en el libro de la oscense Pilar Ponzán, Lucha y muerte por la libertad. Memorias de nueve años de guerra: 19361945. Ed. de la autora, Barcelona, 1996, pp. 111-112. Un caso de parto en el campo de Barcarès lo narra su protagonista, Pepita Solé, esposa del dirigente socialista aragonés Arsenio Jimeno. Su pequeño murió a los pocos meses de nacer, cuando aún permanecían dentro del campo. Entrevista, Pepita Solé. Villemomble, 7 de septiembre de 1999. 
Durante el verano de 1939 comenzaron a producirse salidas de internos, reclamados por familiares residentes en Francia o con un contrato de trabajo que les permitía integrarse en la economía francesa. En estos casos, fue muy importante la colaboración de la emigración económica española anterior a 1936: muchos de aquellos emigrados ofrecieron a sus compatriotas asilo, trabajo o ayuda material de todo tipo. ${ }^{88}$ Las autoridades francesas apoyaban las salidas, ya que favorecían su intención de vaciar los campos. También, según muchos testigos, se trataba de convencer a los internados de que regresasen a la España de Franco, con la promesa de que no serían represaliados «si no tenían las manos manchadas de sangre». Pero las noticias fragmentarias que llegaban del interior de España desaconsejaban tal opción; utilizando trucos para eludir la censura, como escribir debajo del sello, los que habían quedado en el interior informaban a los exiliados de la suerte que les esperaba en España: fusilamientos, cárceles y persecución. Tras la declaración de guerra entre Francia y Alemania este proceso de "deshispanización» de los campos se aceleró, y en ellos comenzaron a entrar otros inquilinos, como los alemanes residentes en Francia, muchos de los cuales eran antifascistas que habían huido de Alemania, perseguidos por sus actividades. ${ }^{89}$

El comienzo de la guerra hizo que las unidades de las CTE fueran militarizadas por decreto de 13 de enero de 1940. El 13 de mayo se transformaron en 120 Compañías de Trabajadores Extranjeros, cada una de ellas con 250 hombres al mando de un oficial de reserva francés y un capitán español; muchas fueron enviadas a reforzar las fortificaciones fronterizas (la

88 En 1936, la emigración económica de origen español en Francia alcanzaba la cifra de 254000 personas, y era la tercera comunidad extranjera más numerosa, tras italianos y polacos. Después de 1939 los españoles pasaron a constituir la colonia extranjera más importante. Geneviève Dreyfus-Armand, "Les oubliés», Hommes et migrations, n. ${ }^{\circ} 1148$, noviembre de 1991, pp. 36-45.

89 Ver, por ejemplo, el testimonio de Lisa Fittko, De Berlín a los Pirineos. Evocación de una militancia. Anaya y Mario Muchnik, Madrid, 1997. Esta mujer fue resistente antifascista en la Alemania nazi y posteriormente tuvo que huir a Francia, donde fue internada en el campo de Gurs con otras muchas mujeres alemanas. Tras conseguir instalarse en el sur de Francia, montará, junto a su marido Hans Fittko, una red de evasión a través de los Pirineos utilizando la denominada ruta Lister (rebautizada como F-route), por la que numerosos judíos y resistentes huyeron de la Francia ocupada. Una de las personas a las que Lisa Fittko ayudó a evadirse fue Walter Benjamin, que se suicidó en la frontera al no permitírsele la entrada en España. 
famosa, y supuestamente infranqueable, Línea Maginot). De este modo, un gran número de españoles se verán atrapados por el avance relámpago de las unidades de la Wehrmacht. Al no tener el estatuto de soldados del ejército regular, fueron internados en stalag desde los que serían deportados a campos de concentración o exterminio, principalmente al complejo concentracionario de Mauthausen, en Austria (compuesto de un campo central y varios campos anejos, como el de Gusen). Esta suerte corrieron unos 12000 españoles, entre los cuales se encontraban no pocos aragoneses. ${ }^{90} \mathrm{La}$ derrota francesa de septiembre de 1940 supondrá el reinternamiento de los republicanos españoles en los campos de concentración.

Bajo la ocupación alemana, la vida francesa sufrió un cambio brutal. La nación quedó dividida en dos zonas tras el armisticio de Compiègne (27 de septiembre de 1940), y la denominada «zona libre» se confió al régimen pro-alemán y fascistizante de Vichy, con el general Pétain a la cabeza. Éste se ocupará de los republicanos españoles, agrupados bajo la categoría de «extranjeros sobrantes en la economía nacional», creando los Groups de Travailleurs Étrangers (GTE), herederos de las CTE pero con un carácter represivo que los aproximaba más a los batallones disciplinarios que en el mismo momento funcionaban en la España franquista. Los GTE, integrados en gran medida por españoles, representaban una mano de obra de muy bajo coste para las autoridades de Vichy; tanto es así que se registraron conflictos y protestas de los franceses desmovilizados, que se encontraron en el paro al volver a sus hogares porque una parte de los puestos de trabajo habían sido ocupados por estos trabajadores, a los que se destinaba a «industrias prioritarias» (acererías, carbonerías, serrerías...). Así se desprende, por ejemplo, de una carta anónima dirigida a la prefectura del departamento del Loira en octubre de 1940 y firmada por «un français qui veut manger», o, de forma más oficial, de la denuncia cursada por el presidente de la Liga de Familias Numerosas, fechada en diciembre de 1940, para comunicar al prefecto de Loira que la Manufactura Nacional de Armas, situada en la localidad de Saint Étienne, empleaba obreros extranjeros, cuando había padres de familia franceses en paro. ${ }^{91}$ Por tanto, el des-

90 Destacamos principalmente las memorias de uno de estos aragoneses: Mariano Constante, Los años rojos: españoles en los campos nazis. Martínez Roca, Barcelona, 1974, así como Republicanos aragoneses en los campos nazis. Pirineo, Huesca, 2000.

91 Archives Départamentales de la Loire. Série 2W1203: Main d'oeuvre étrangère (1940-41). 
tino laboral de estos trabajadores extranjeros negaba la publicidad y la retórica fascista del régimen de Vichy: «Patria, Familia, Trabajo».

Pero había otra función a la que se destinaba a los componentes de los GTE: abastecer de mano de obra a los alemanes, que reclutaban trabajadores por medio de la denominada Organización Todt. ${ }^{92}$ Podían trabajar en las fortificaciones del Muro del Atlántico, llevar a cabo otro tipo de tareas en Francia (generalmente relacionadas con la ingeniería militar) o ser enviados a Alemania. Eran las autoridades francesas las que, en primera instancia, decidían qué extranjeros habían de ser "preseleccionados» para satisfacer las demandas alemanas: en una circular ministerial de 24 de abril de 1943, momento en que toda Francia estaba ocupada por los alemanes y las demandas de Todt se hacían cada vez más acuciantes, se especifica que los contingentes reclamados debían estar formados por refugiados españoles, rusos, armenios o bien por voluntarios, por este orden. En otra circular de 17 de agosto se insistía en que sólo se entregarán a la Organización Todt, de entre los refugiados que hubiesen perdido la protección de sus países de origen, a los refugiados españoles, rusos blancos y armenios; el resto no debían ser sometidos a esta medida. ${ }^{93}$

Todo ello muestra que el régimen de Vichy, un régimen de por sí excluyente y xenófobo, sometió a los españoles a una represión específica. Aparte de otras explicaciones que se detallarán más adelante, las inadmisibles condiciones del exilio francés son probablemente una causa determinante de la fuerte presencia de españoles en las diferentes organizaciones de la Resistencia francesa. Como apunta Geneviève Dreyfus-Armand, "los refugiados españoles son colocados inmediatamente en el corazón de la política de exclusión puesta en marcha por Vichy y son sometidos a una vigilancia constante y multiforme tanto por parte del Estado francés [...] como por parte del ocupante alemán y de la embajada de España». ${ }^{94}$ Lo cual nos lleva a

92 La Organización Todt, creada en 1938, recibió este nombre del ingeniero constructor de la Línea Sigfrido, que ocupaba el cargo de ministro de Armamento del Reich. Era la organización encargada de construir la fortificaciones estratégicas en los países ocupados, y en Francia gestionó la construcción del Muro del Atlántico.

93 Archives Départamentales de la Loire. Série 2W81: Travailleurs étrangers (1940-46).

94 Geneviève Dreyfus-Armand, "L’immigration politique des républicains espagnols en France», en Rencontre Guerre d'Espagne et immigration espagnole. VO éditions, Toulouse, 1997, pp. 73-84, cita en p. 78. 
recordar que Pétain fue el primer embajador francés en la España de Franco, o el buen entendimiento entre Franco y Pétain cuando éste alcanzó el poder, o el refugio que Pierre Laval, «segundo de a bordo» del régimen pétainista, encontró en Barcelona cuando la Liberación le obligó a abandonar Francia para evitar ser procesado. La colaboración funcionaba, por lo tanto, en los dos sentidos. ${ }^{95}$

Desde el momento en que los españoles republicanos fueron internados en los campos, los más politizados llevaron a cabo acciones destinadas a reconstruir sus organizaciones políticas. Tarea difícil, puesto que éstas habían sido completamente desmanteladas y la desorientación en que estaban sumidos los españoles en el exilio no favorecía su reorganización. Dispersos en campos de concentración, compañías de trabajadores y centros de internamiento, su primera prioridad era sobrevivir en un país extraño y sobreponerse a la terrible decepción provocada por el recibimiento que les dispensaba la Francia democrática y republicana. Además, los españoles llevaron consigo al exilio las divisiones y fracturas del campo republicano. Las organizaciones políticas y sindicales estaban desintegradas, sus miembros dispersos, muchos de sus dirigentes desaparecidos o muertos. Por lo tanto, hubo una primera y trabajosa etapa de reorganización, en la cual los exiliados comenzaron a reunirse por afinidades políticas en el interior de los campos. En cuanto a los dirigentes republicanos, de entre aquellos que habían sobrevivido a la represión franquista y alcanzado el exilio pocos permanecerían en Francia, y aún menos iban a pasar por la experiencia de los campos de concentración. La mayoría de los dirigentes socialistas marchó a Méjico, lugar de exilio de Indalecio Prieto o Amaro del Rosal; la conocida excepción es Largo Caballero, que fue internado en un campo alemán y moriría poco después de la Liberación a causa de las penalidades sufridas. En cuanto a la cúpula comunista, encontró refugio en Moscú, con la excepción de Francisco Antón, que pasó por un campo de concentración francés, aunque por breve tiempo. La reorganización en Francia fue fruto, pues, de un puñado de militantes destacados, no de los dirigentes de la época republicana, ni siquiera de la guerra.

Además, los exiliados se enfrentaban a otras dificultades: la división del PSOE, por ejemplo, o la ilegalización del PCE, junto con el PCF y cual-

95 Le Monde, 8/5/45. 
quier organización comunista francesa o extranjera, a raíz del pacto firmado por Molotov y Ribbentrop poco después de la declaración de guerra entre Francia y Alemania. En cuanto al POUM y el Movimiento Libertario, el primero tenía una presencia casi testimonial, y el segundo también se hallaba dividido y falto de "cabezas visibles». Y tras el establecimiento del régimen de Vichy en 1941, sobre los españoles se abatió una ola represiva que afectó fundamentalmente al POUM, el cual nunca se rehízo y no volvería a tener una presencia destacable en el exilio: casi todos sus dirigentes fueron arrestados en Montauban, donde habían rehecho un esbozo de organización, y condenados a largas penas de cárcel. Muchos de los anarquistas que aún quedaban en libertad a finales de 1941 fueron arrestados e internados en el campo de Vernet, donde se encontraban los miembros de la Columna Durruti. Y en cuanto a la represión contra los comunistas españoles, casi todos sus efectivos en zona ocupada fueron arrestados en la primavera de 1942. El PCE se había organizado en París, en el otoño de 1940, gracias al contacto con antiguos miembros de las Brigadas Internacionales, sobre todo con Arthur London, particularmente a través de su mujer, Lisa Ricol (Lise London), de origen aragonés. Pero tras las caídas de 1942, el PCE nunca llegaría a tener una estructura fuerte en esa zona: los comunistas de la zona norte se integraron en organizaciones francesas, sobre todo en los FTP-MOI. A finales de 1942 tuvo lugar también una gran ola represiva en el sudoeste, que desembocó en las detenciones de los que formarían posteriormente, en un juicio que alcanzó una gran difusion, el expediente "Reconquista de España». El juicio tuvo lugar en Toulouse entre enero y junio de 1944, y 13 de los 131 inculpados fueron condenados a penas de prisión y encarcelados en Saint Michel. El 30 de julio de 1944, sin embargo, fueron entregados a las autoridades alemanas junto con otros 27 prisioneros políticos, entre los que se encontraba el anarquista aragonés Francisco Ponzán. Nunca se les volvió a ver con vida. ${ }^{96}$

El comienzo de la reorganización de la base comunista en Francia suele situarse en el campo de concentración de Argelès-sur-Mer. Allí, un grupo de militantes comunistas que habían ocupado puestos de importancia durante la guerra civil, y entre los cuales se encontraban Sixto Agudo y Antonio

96 Geneviève Dreyfus-Armand, "L'immigration politique...", op. cit., y L'exil des Républicains espagnols en France. De la guerre civile à la mort de Franco. Albin Michel, París, pp. 150 y 155. 
Rosel (que posteriormente influirían en la reconstrucción del partido en Aragón), se reunieron junto con representantes del campo de Rivesaltes y un delegado del Comité Central en Francia, encabezado en esos momentos por Jesús Monzón Reparaz y Carmen de Pedro. De este contacto surgió en agosto de 1940 una dirección del PCE en Francia, y el grupo que se constituyó en Argelès llegaría a ser uno de los núcleos iniciales de la resistencia española en Francia. En esta reunión varios militantes, entre ellos Agudo y Rosel, se ofrecieron a volver a España; Antonio Rosel, con la ayuda de su compañera Victoria desde Zaragoza, fue uno de los primeros en conseguirlo. ${ }^{97} \mathrm{El}$ grupo de Argelès se puso bajo las órdenes de la delegación del Comité Central en Francia, es decir, de Jesús Monzón, y de este modo el PCE comenzó a reestructurarse en el exilio francés. Cuando se puso en marcha la política de salida de los españoles de los campos encuadrados en las CTE y, posteriormente, en los GTE, los comunistas aprovecharon para extender la organización..$^{98}$ Tras su evasión del campo de Argelès, Sixto Agudo se trasladó al departamento de Aude en otoño de 1941, y comenzó a trabajar con unos carboneros del dominio de Majou, propiedad de M. Delteil, miembro de la Resistencia gaullista. Allí se encontraba también, entre otros comunistas españoles, el aragonés Jesús Ríos, antiguo comisario de la 234 Brigada de Guerrilleros del XIV Cuerpo de Ejército durante la guerra civil. Y este grupo conformará la primera partida de guerrilleros españoles organizada por el PCE en territorio francés. ${ }^{99}$

En noviembre de 1942, el PCE celebró cerca de Montauban el denominado "Congreso de Grenoble», en el cual se hizo público un llamamiento a todas las organizaciones políticas españolas, incluidas las de la derecha no falangista (los monárquicos y la CEDA), para promover la unidad en la lucha contra el régimen de Franco a través de la organización Unión Nacional Española (UNE). Era la expresión de una consigna de unidad de acción entre los partidos antifranquistas que el PCE había lanzado en el verano de 1941 siguiendo directrices de Moscú, política que fue posible por la invasión alemana de la URSS, que permitió a los partidos comunistas recuperar una línea política antifascista. Al mismo tiempo, en

97 Sixto Agudo, "Yo fui testigo...", en Historias de maquis en el Pirineo aragonés. Pirineum Editorial, Jaca, 1999, pp. 105-138, p. 113.

98 Entrevista, Sixto Agudo. Alcampell, 22 de diciembre de 1995. Ver también Sixto Agudo, En la Resistencia francesa. Anubar, Zaragoza, 1985.

99 Sixto Agudo, "Yo fui testigo...», op. cit., p. 115. 
el interior de España Jesús Monzón promovía la creación de una "Junta Suprema de Unión Nacional», en la cual, al parecer, participaban representantes de todas las fuerzas políticas convocadas. ${ }^{100}$ Pero, probablemente, de la UNE sólo formaron parte fracciones minoritarias del resto de organizaciones en el exilio, mientras que los demás partidos republicanos se agrupaban en otras asociaciones: la Junta Española de Liberación (JEL) se creó en Méjico en 1943 por iniciativa de Prieto y Martínez Barrio, y en octubre de 1944 nació la Alianza Nacional de Fuerzas Democráticas (ANFD), con la que se esperaba contrarrestar la influencia comunista.

A finales de 1941, y tras una reunión en Toulouse a la que asistieron 12 guerrilleros que trabajaban en los grupos de carboneros del Aude, la UNE de la «zona libre» decidió organizar los primeros grupos de guerrilleros españoles en los departamentos de Aude y Ariège, contando para ello con la colaboración de antiguos guerrilleros del ejército republicano, acostumbrados a actuar en la retaguardia enemiga. ${ }^{101} \mathrm{El}$ mismo año comenzó a funcionar la emisora clandestina Radio España Independiente, conocida popularmente como "la Pirenaica» (a pesar de que emitía desde la Unión Soviética y, posteriormente, desde Rumanía), que representará un papel fundamental en la transmisión de las órdenes y consignas de la dirección del PCE a los grupos guerrilleros y militantes del interior de España. Y también a partir de 1941 comenzó a publicarse en Francia de forma clandestina Reconquista de España, el órgano de la Unión Nacional. En un principio se confeccionaba en una imprenta oculta en una granja del departamento de Vaucluse y posteriormente se editó en Toulouse; en la denominada «zona libre» aparece de forma regular desde el mes de julio. En la «zona ocupada» aparece desde marzo de 1942 como resultado de la fusión entre Reconquista de España y España Popular; se editaba en París. ${ }^{102}$ Sixto Agudo fue uno de los responsables de la publicación en la zona sur;

100 Según Gregorio Morán, la denominada "Junta Suprema» fue una creación de Jesús Monzón bastante posterior al «Congreso de Grenoble», y en ella sólo participaba el PCE, en Gregorio Morán, Miseria y grandeza del Partido Comunista de España, 1939-1985. Planeta, Barcelona, 1986, pp. 83-92.

101 Historique de l'État-Major des Guerrilleros Espagnols en France. Documento mecanografiado, s.a., s.l., s.f., archivo personal de Luis Fernández. Consultado gracias a la amabilidad de su hija, Irène Tenèze. Sixto Agudo, "Yo fui testigo...», op. cit., p. 117.

102 Ver Geneviève Dreyfus-Armand, L'émigration politique espagnole en France au travers de sa presse, 1939-1975. Institut d'Études Politiques de Paris. Thèse doctorale, 1994. 
también lo fue la Escuela de Formación Politicomilitar Cara a España de la montaña Negra (Aude), que el PCE puso en marcha en cuanto tuvo capacidad operativa para ello, ayudado por el PCF. Anteriormente, Sixto Agudo había sido el reponsable del PCE en la zona sur, cargo en el que le sustituyó Miguel López. ${ }^{103}$

De este modo, durante los años comprendidos entre 1940 y 1942 el PCE iba organizando una estructura departamental con vistas a varios objetivos: la reorganización de la militancia y la puesta en pie de un aparato que le permitiese prepararse militarmente para llevar a cabo lo que el nombre del periódico de Unión Nacional expresaba en su título, es decir, la «reconquista de España». Éste era, pues, un objetivo presente en los planteamientos del PCE desde el primer momento de su reorganización; como indica Émile Témime, es algo que no debe olvidarse para comprender la táctica de los guerrilleros españoles en Francia. En palabras de Claude Delpla, citado por Témime, "la historia de los guerrilleros en Francia no puede disociarse de la de las guerrillas en España». ${ }^{104} \mathrm{Y}$ viceversa, añadiríamos. Pero antes de enfrentarse al franquismo debían luchar contra el enemigo más próximo: el régimen colaboracionista de Vichy y, posteriormente, los alemanes.

La Unión Nacional Española, mediante la cual el PCE pretendía reagrupar en torno a sí a las organizaciones políticas no fascistas (en realidad, dispersas y desestructuradas) mediante una política inspirada en los frentes nacionales que se organizaron en muchos países ocupados (organizados, generalmente, por los partidos comunistas nacionales siguiendo las directrices de la Komintern), sirvió en realidad para que el Partido Comunista reorganizase sus fuerzas y facilitó su participación en la Resistencia francesa, así como la preparación de la resistencia interior. En principio actuó como un elemento aglutinador, e hizo que numerosos españoles no comunistas pudiesen encuadrarse en una organización de resistencia estructurada y llevar a cabo un combate efectivo sin renunciar a sus mili-

103 Claude Delpla, Les guerrilleros espagnols dans la zone pyrénéenne. Texto mecanografiado, s.l., s.f.

104 Émile Témime, «Problèmes stratégiques des guerrilleros et de la guérrilla espagnole dans la Résistance en France», en François Marcot (dir.), La Résistance et les Français. Lutte armée et maquis. Actes du Colloque international de Besançon, 15-17 juin 1995. Annales littéraires de l'Université du Franche-Comté, 1996, pp. 269-278, cita en p. 278. 
tancias políticas, puesto que la UNE admitía a miembros de todas las formaciones políticas. Lo cual, por otra parte, da la medida de las ambiciones de la UNE, que en su prensa y su propaganda se declaraba representante unitaria de los intereses de todos los republicanos en el exilio. Más allá de la organización de grupos guerrilleros, la UNE pretendía también dirigir la acción sindical, en la medida en que podía realizarse una acción de este tipo. Así, a través de Reconquista de España hizo llamamientos dirigidos a los obreros españoles en los que se recordaban los éxitos logrados por la UGT y la CNT a lo largo de su historia, se apelaba a la participación en grupos de guerrilleros, pero sobre todo se llamaba a la huelga en las empresas controladas por la Organización Todt y a la lucha sindical para evitar la deportación de obreros. En las páginas de Reconquista de España leemos que la Unión Nacional aspiraba a la creación de una central sindical única "con vistas a la lucha sindical en España y aquí». Por lo tanto, su actividad se desarrollaba en tres frentes tácticos, el político, el militar y el sindical, y se extendía a los dos ámbitos geográficos que separaban a los vencidos de la guerra civil a uno y otro lado de los Pirineos. ${ }^{105}$

Sin embargo, la primera aportación efectiva de los españoles a la Resistencia en Francia no partió de la organización militarizada de los comunistas, sino que consistió en el franqueamiento clandestino de la frontera pirenaica a través de diversos pasos de montaña, mediante redes creadas muchas veces en connivencia con los servicios secretos aliados, y otras veces fruto de iniciativas individuales. De estas redes, una de las más importantes y efectivas fue la creada por el anarquista oscense Francisco Ponzán, François Vidal en la Resistencia, que formaba parte de la red Pat O'Leary, organizada por los servicios secretos ingleses para sacar de territorio francés a los aviadores británicos que caían en Francia. En concreto, dicha red contaba con el apoyo del SOE, que era el organismo creado por los ingleses para intervenir en los países ocupados y que, en este caso, mantenía contactos también con los servicios secretos franceses.

Francisco Ponzán había sido dirigente del Consejo de Aragón, la institución creada por los anarquistas durante la guerra civil para coordinar el funcionamiento de las colectividades agrarias aragonesas, y, acabada la

105 Reconquista de España. Órgano de Unión Nacional de todos los españoles. París (edición de la zona ocupada), octubre-noviembre de 1943. 
guerra, como tantos otros, fue a parar a un campo de concentración francés. Tras conseguir escapar, y gracias a sus contactos, organizó junto a su hermana Pilar y otros antiguos colaboradores un pequeño grupo con base en Toulouse en septiembre de 1940, que se dedicaba a ayudar a diferentes personas a franquear la frontera en una y otra dirección. Este grupo contaba con una base de operaciones en Zaragoza, y el propio Ponzán penetró en varias ocasiones en territorio español. Hacia 1941, Pat O'Leary (cuyo verdadero nombre era Albert Guérisse) logró contactar con él y le propuso que el grupo Ponzán entrara a formar parte de su red. De este modo, Francisco Ponzán realizó una importante labor de colaboración con los servicios secretos aliados. Ponzán fue capturado en dos ocasiones por los alemanes, que finalmente lo fusilaron en Buzet junto a un grupo de prisioneros el 17 de agosto de 1944, poco antes de la Liberación, en uno de los ajusticiamientos sumarios que los alemanes efectuaron ante la inminencia de la derrota. ${ }^{106}$

Volviendo al Partido Comunista, su grado de organización y militarización le permitió crear, en abril de 1942, el XIV Cuerpo de Ejército de Guerrilleros Españoles, a cuya cabeza se colocó a Jesús Ríos, reemplazado al ser detenido en 1943 por Silvestre Gómez, y que participaría en la Resistencia en estrecha colaboración con los FTP-MOI. Sin embargo, las unidades de guerrilleros españoles eran controladas únicamente por el Estado Mayor del XIV Cuerpo de Guerrilleros Españoles, que mantenía su independencia como formación armada unida directamente al movimiento de resistencia española UNE. ${ }^{107}$ El nombre proviene del de una unidad de voluntarios constituida durante la guerra civil, en 1937, y cuyo comisario político era Pelegrín Pérez, que posteriormente fue un destacado guerrillero tanto en Francia como en España, en la zona de Levante. ${ }^{108}$ En cuanto

106 Antonio Téllez, La red de evasión del grupo Ponzán. Anarquistas en la guerra secreta contra el franquismo y el nazismo. Virus, Barcelona, 1996, y Pilar Ponzán, Lucha y muerte por la libertad. Memorias de nueve años de guerra: 1936-1945. Ed. de la autora, Barcelona, 1996. Es posible que entre los prisioneros políticos que murieron junto a Francisco Ponzán estuviesen los componentes del expediente «Reconquista de España». Ver Geneviève Dreyfus-Armand, L'exil des républicains..., op. cit., p. 150.

107 Historique de l'État Major..., doc. cit.

108 Antonio Gascón, "1944: la "Reconquista" empieza en los Pirineos», Historia y Vida, extra n. ${ }^{\circ}$ 81, 22. ${ }^{\circ}$ trimestre de 1996, pp. 79-83. Pelegrín Pérez llegó a ocupar en 1948 el puesto de jefe de la Agrupación Guerrillera de Levante y Aragón. 
al modo de formar las unidades de guerrilleros, en general los guerrilleros eran reclutados a partir de los GTE; muchos grupos de trabajadores eran enviados a trabajar en chantiers en el monte, cortando leña para fabricar carbón vegetal, en serrerías y empresas forestales o en la construcción de pantanos, y allí se producían los contactos o, directamente, se creaban los maquis, los campamentos-refugio de los guerrilleros o maquisards. ${ }^{109}$ Estos campamentos o maquis habían servido inicialmente de refugio a los jóvenes franceses refractarios al STO, que huían al monte para evitar su cumplimiento y entre los cuales se encontraban muchos jóvenes del PCF, que dotaron a los campamentos de fugitivos de una organización y de un objetivo: ser núcleos de resistencia contra los alemanes. Muchos españoles huyeron de los GTE y se unieron a ellos en el monte. Otros españoles trabajaban en la construcción de pantanos, como Marèges o Bort-les-Orgues y sobre todo el pantano del Águila en el departamento de Cantal, donde había un importante núcleo de anarquistas españoles, o como el de Larroquebrou, también en Cantal, origen de las guerrillas comunistas en aquel departamento. En dichos puntos, los españoles reorganizaron sobre el terreno sus organizaciones políticas, de forma autónoma, y posteriormente tomaron contacto con el aparato de las organizaciones; estos lugares pronto se convertirán en nuevos núcleos de la Resistencia.

En concreto, el grupo del pantano del Águila, formado hacia finales de 1941, fue el primer núcleo a partir del cual se reestructuró la CNT clandestina en Francia, en un momento en que el Consejo Nacional Libertario no daba señales de vida. El grupo, en el que se encontraba José Berruezo, constituyó un Comité Nacional de la CNT. Pero al mismo tiempo, y a causa de la falta de conexión entre los diferentes grupos, se constituía otro Comité Nacional en Montpellier por iniciativa de Juan Manuel Molina, en el cual participaba también Manuel Buenacasa. Además surgieron varios grupos locales en el departamento de Ariège. Los diferentes elementos carecían de coordinación entre sí, y los libertarios no se decidieron a entrar colectivamente en la Resistencia francesa. Por tanto, la participación de los anarquistas se canalizó a través de la UNE (oficialmente condenada por los

109 Como se ve, la denomimación maquis no se refiere a los guerrilleros sino al lugar en el que éstos tenían establecida su base. La palabra proviene del corso (macchia) y alude a un tipo de vegetación mediterránea. La palabra fue importada de la resistencia corsa a la francesa, y de ahí pasó a España, donde maquis pasó a denominar tanto el movimiento guerrillero como a las personas que lo integran. 
dirigentes libertarios), de organizaciones francesas o de grupos autónomos. De hecho, entre los propios anarquistas del pantano del Águila hubo una escisión entre los que se decidieron a ingresar en la UNE y los que prefirieron montar un maquis por su cuenta, maquis que tenía, parece ser, un carácter más defensivo que ofensivo, cosa que les reprocharon posteriormente los comunistas, acusándolos de «attentistes». ${ }^{110}$

Un ejemplo paradigmático (y a la vez excepcional por su duración y efectividad) de los chantiers establecidos por el PCE en la zona sur fue la empresa de explotación forestal creada por los comunistas José Antonio Vallador y Luis Fernández en el departamento de Aude, que trabajaba conjuntamente con la empresa forestal Georges Thomas, en el departamento de Ariège, lo que facilitaba el tránsito de guerrilleros de un departamento a otro. De esta forma, poco después de la organización del grupo guerrillero de Aude se formará otro en Ariège. Oficialmente, la empresa se denominaba Entreprise Forestière du Sud-Ouest, y sus chantiers fueron los primeros centros político-militares con los que contó el PCE en la zona sur. La tapadera funcionó hasta su desmantelamiento por la policía francesa en 1950 (año en que el PCE es declarado ilegal en territorio francés); hasta esa fecha los chantiers fueron bases de capacitación y entrenamiento de los guerrilleros que posteriormente eran enviados al interior de España.

Pero la organización de un grupo guerrillero no siempre era un proceso dirigido "desde arriba», sino que en ocasiones era un movimiento con un alto grado de espontaneidad. Un ejemplo de cómo se organizaban estos grupos combinando la espontaneidad con la acción dirigida por las organizaciones nos lo proporciona un grupo de aragoneses de Canfranc, ${ }^{111}$ antiguos combatientes de la 43. a División, algunos de ellos con el grado de oficial (y uno, el anarquista Hilario Borau, segundo de Antonio Beltrán, el Esquinazau). Después de la derrota francesa y tras salir de los campos, fueron contratados por

110 Émile Témime, «Problèmes stratégiques...», op. cit.; José Berruezo, Contribución a la historia de la CNT de España en el exilio. Editores Mexicanos Unidos, Méjico, 1967; y José Borrás, Del radical-socialismo al Socialismo Radical y Libertario. Memorias de un libertario. Fundación Salvador Seguí, Madrid, 1998. Seguir la trayectoria de los anarquistas en Francia antes de 1944 es sumamente complicado, por la dispersión en la que quedaron, la división en el seno del MLE y la ausencia de documentos.

111 En la medida de lo posible, hemos tratado siempre de seguir la pista de los aragoneses y aragonesas que participaron en la Resistencia francesa, para relacionarlos posteriormente con la resistencia interior, y los ejemplos suelen referirse a ellos. 
la Sociedad Auxiliar de Empresas Eléctricas y Obras Públicas para construir un embalse próximo a la frontera pirenaica, en la zona de Bagnères de Bigorre, cerca de Somport. Allí fue destinado también en septiembre de 1941 un GTE compuesto por 250 refugiados españoles, la mayoría comunistas, aunque también había anarquistas, socialistas y antiguos militantes de Izquierda Republicana. Estos refugiados eran vigilados estrechamente, pero el campamento en el que se alojaban les sirvió de base logística para reconstituir sus organizaciones políticas. Comenzaron a circular entre ellos algunos ejemplares de Reconquista de España, y al cabo lograron hacerse con una pequeña imprenta para la reproducción de estos ejemplares y su posterior distribucion por la zona. Sirviéndose del contacto con los aragoneses contratados en régimen individual por la empresa, que podían moverse con libertad, los miembros del GTE establecieron enlaces con el exterior. Y de esta forma, a finales de 1941 tomaron contacto con la MOI de los Bajos Pirineos, dirigida por Félix Burguete (también aragonés, de Zaragoza), y con Sixto Agudo y Agustín Cortés, este último natural de Echo, responsables regionales del PCE. Así se tejió una red que permitió, cuando comenzaron las requisas para el STO, el establecimiento del primer maquis del Bearn y Bajos Pirineos.

Además, este grupo de españoles se beneficiaba de la connivencia e incluso la colaboración abierta de la población, a pesar de la propaganda negativa acerca de los españoles que difundía gran parte de la prensa francesa. Las relaciones comerciales, de paso de personas y mercancias, entre las poblaciones de los valles de Aspe y Ossau y los valles de Echo, Ansó y Aragón eran tradicionales, y la población montañesa vivía a ambos lados de la frontera la condición pirenaica como una seña de identidad común. Ello dio lugar a una red de solidaridad entre estos republicanos de Canfranc y los campesinos bearneses. Existen, pues, un sentimiento de vecindad y una solidaridad marcados por el entorno geográfico y la similitud de modos de vida que atraviesan las fronteras nacionales y las identidades políticas, y que se manifiestan de forma aún más fuerte ante la presencia de un elemento percibido, éste sí, como externo y hostil: los ocupantes alemanes. De hecho, varios habitantes de la zona fueron detenidos por colaborar con la resistencia española. Y esta colaboración es la que los guerrilleros españoles esperaban encontrar al otro lado de la frontera. ${ }^{112}$

112 Jean Ortiz, «La résistance espagnole en Béarn», en Les Espagnols et la guerre civile. Atlantica, Biarritz, 1999, pp. 379-409, cita en p. 397. Testimonio escrito de Sixto Agudo, s.f., archivo personal de la autora. Entrevista, Luis Gimeno. Echo, 8 de mayo de 1999. 
En mayo de 1944, el XIV Ejército de Guerrilleros Españoles se transformó en la Agrupación de Guerrilleros Españoles (AGE), que ya no tenía ligazón orgánica con los FTP-MOI, puesto que la lucha en España comenzaba a perfilarse como un objetivo posible y el Estado Mayor de los Guerrilleros Españoles, de filiación comunista y estrechamente relacionado con la dirección de la UNE, deseaba contar con autonomía para lanzarse a un ataque sobre la frontera pirenaica. Pero antes tuvieron lugar los combates de la Liberación, en los cuales los guerrilleros españoles tuvieron un gran protagonismo. La AGE formará parte de las Forces françaises de l'intérieur (FFI), organizadas en diciembre de 1943 cuando todos los elementos que componían la Resistencia interior se agruparon y coordinaron bajo el mando del Conseil national de la Résistance (CNR), máximo órgano de la Resistencia en el interior, que se creó gracias a la iniciativa de algunos jefes de la Resistencia próximos a De Gaulle, como Jean Moulin, y que sólo dependía del Comité français de libération nationale, presidido por los generales De Gaulle y Giraud, en principio, y posteriormente sólo por De Gaulle, con sede en Argel.

Sin embargo, la AGE mantuvo siempre cierta autonomía operativa, como ya se ha indicado, y dependía directamente de las FFI. Algunos jefes de divisiones de guerrilleros españoles que eran al mismo tiempo jefes militares de unidades de la MOI dejaron éstas para dirigir únicamente unidades compuestas por españoles, aunque se conservaron buenas relaciones con los FTP-MOI. ${ }^{113}$ Los dirigentes comunistas tenían claro que deseaban mantener el carácter político de la organización para no perder de vista la verdadera razón de ser de toda la estructura puesta en pie desde 1940, que no era militar sino política, y que no finalizaba con la Liberación de Francia. Las llamadas a las armas son un recordatorio de estas condiciones: "los Comités de UN, sin perder la dirección politica un solo instante, deben transformarse desde este momento en Comités de Movilización y Combate». ${ }^{114}$ El objetivo era España, y tras la Liberación de París la UNE enfocó todo su discurso, todas sus energías hacia dicho objetivo. Como preparación para la operación de penetración en territorio español que los mandos comunistas empezaban a sopesar seriamente, Silvestre

113 Historique de l'État Major..., doc. cit.

114 Reconquista de España. Órgano de Unión Nacional de todos los españoles. París (edición de la zona ocupada), junio de 1944 , n. ${ }^{\circ} 32$, n. ${ }^{\circ}$ extraordinario. La cursiva es mía. 
Gómez fue enviado en misión de reconocimiento al interior, en una operación de la que también formaba parte, entre otros, Sixto Agudo. Ello obligó a una reestructuración de la dirección de la AGE; su reponsable máximo sería el general Luis Fernández, y el Estado Mayor se compondría además del general Juan Blázquez (comisario político), el coronel Miguel Ángel Sanz y el coronel José Antonio Paz (oficial de enlace). El cuartel general se estableció en Gaillac.

Pero los españoles que participaban en la Resistencia francesa, de forma masiva a partir del desembarco aliado del 6 de junio de 1944 y del comienzo de los combates de la Liberación, no lo hacían solamente encuadrados en las estructuras de la AGE (a pesar de que el desembarco aliado impulsó a la AGE a realizar un reclutamiento masivo entre los refugiados españoles). ${ }^{115}$ Muchos de ellos formaban parte de unidades de la MOI, de otras organizaciones resistentes o de grupos autónomos, como los anarquistas del maquis del pantano del Águila. La militancia política suele determinar en gran medida la modalidad de participación en la Resistencia, así como cada trayectoria individual; muchos republicanos no comunistas rechazaban la participación en la guerrilla de la UNE, principalmente grupos anarquistas que preferían actuar de forma autónoma. Entre estos anarquistas perduraba una fuerte desconfianza hacia los comunistas, que les impelía a organizarse por su cuenta y a denunciar las maniobras hegemonizadoras de la resistencia comunista, aunque el conflicto entre comunistas y Movimiento Libertario se haría patente sobre todo tras la Liberación, momento en el que hubo varios incidentes entre guerrilleros anarquistas y comunistas, los cuales, al parecer, llevaron a cabo represalias y asesinatos contra los libertarios que no pertenecían a la Unión Nacional. ${ }^{116}$ También encontramos muchos anarquistas entre las tropas de la France Libre, y anarquistas eran la mayoría de los españoles que integraban la División Leclerc. Algunos socialistas, como el aragonés Arsenio Jimeno, miembro del Comité Nacional de la UGT desde 1933, tomaron contacto con organizaciones francesas, como France d'Abord, movimiento de resistencia del que Jimeno formó parte. ${ }^{117}$ Y la

115 Historique de l'État Major..., doc. cit.

116 1944: les dossiers noirs d'une certaine résistance. Trajectoires du fascisme rouge. Dossier réalisé par le groupe Puig Antich de la Fédération Anarchiste de Perpignan. Édition du CES, supplément à «Infos et analyses libertaires», 1984.

117 Archivo personal de Arsenio Jimeno. Consultado gracias a la amabilidad de su viuda, Pepita Solé. 
opción de la MOI, finalmente, sería también escogida por muchos españoles por razones más personales que políticas, aunque se tratara de una organización comunista; en general, la mayoría de los españoles que vivían en Francia antes de 1936 y que participaron en la Resistencia lo hicieron a través de la MOI. En el célebre grupo Manouchian (que era una brigada de la MOI), que cayó en diciembre de 1943 en París, había un español, Celestino Torres, y también encontramos a otros dos españoles, Luis Fernández y Joaquín Ramos, en la 35. Brigada de la MOI, la brigada Marcel Langer, que actuaba en el departamento de Alto Garona con base en Toulouse y estaba compuesta por antiguos miembros de la Brigadas Internacionales de diversas nacionalidades. De hecho, según D.W. Pike, el español Joaquín Ramos era el comandante de la Marcel Langer. ${ }^{118}$ Esta diversidad que acabamos de exponer tiene otra consecuencia, que afecta directamente a la investigación histórica: la práctica imposibilidad de realizar un recuento de los españoles que participaron en la Resistencia francesa. ${ }^{119}$

Por lo tanto, podemos afirmar que las lealtades políticas, por un lado, y las redes personales, por otro, determinan la modalidad de pertenencia a la Resistencia francesa de los republicanos españoles. Lealtades políticas $\mathrm{y}$ redes personales que tienen su origen en la guerra civil española y que se reproducen fielmente en el exilio. Los militantes de las diversas organizaciones se buscan entre sí, y entre aquellos que habían sido compañeros de armas en España se crean lazos muy fuertes que los empujan a volver a combatir juntos. Esto es válido no sólo para los españoles sino también para los antiguos brigadistas. Las redes tejidas entre antifascistas de diversas nacionalidades durante la guerra civil española iban a condicionar la estructura, e incluso las estrategias, de una parte importante de los resistentes en Francia, entre los que la presencia de antiguos brigadistas era, como hemos visto, muy significativa. Por el contrario, las viejas rencillas, principalmente las que enfrentaban a anarquistas y comunistas, seguían vigentes, aunque un sector del Movimiento Libertario decidió formar parte de la UNE, lo cual provocaría fuertes disensiones entre los anarquistas del exilio. En suma, la guerra civil es el catalizador que estructura la

118 D.W. Pike, In the service..., op. cit.

119 Geneviève Dreyfus-Armand cifra los efectivos de la UNE en vísperas de la Liberación en unos diez mil hombres en toda Francia. Geneviève Dreyfus-Armand, "Les Espagnols dans la Résistance: incertitudes et spécificités», en J.M. Guillon y Pierre Laborie (dirs.), Mémoire et histoire..., op. cit., pp. 201-216. 
Resistencia en Francia contra los alemanes, pero no sólo la de los españoles, sino en general, a través de la participación de numerosos futuros líderes de la Resistencia en la guerra de España encuadrados en las Brigadas Internacionales. Como indica Geneviève Dreyfus-Armand, «la continuidad entre la participación en la guerra de España y las primeras incorporaciones a la Resistencia está hoy día bien establecida», reflexión que hace también una de las figuras más emblemáticas de la Resistencia, Henri Rol-Tanguy, jefe de las FFI de la región de París y antiguo brigadista. ${ }^{120}$ Pero no se trata solamente de la participación en la Resistencia; la experiencia de la guerra civil determinó también las formas que adoptó dicha participación.

Lo que se ha afirmado antes acerca de las modalidades de encuadramiento en la Resistencia francesa es válido asimismo para las mujeres. Sobre todo para las de nacionalidad no española que formaron parte de las Brigadas Internacionales, pero también para las españolas que habían combatido como milicianas o que habían ocupado algún puesto político de responsabilidad. Incluso aquellas que no habían ejercido actividades políticas ni militares durante la guerra civil encontraron en la Resistencia francesa formas de participación como enlaces, encubridoras, agentes de información, etc. También participaron, aunque en casos muy concretos, en la acción armada. Es especialmente destacable el caso de Claude Gérard, jefe de maquis para los siete departamentos de la región 5 de las FFI. ${ }^{121}$ Encontramos incluso a una española, Lina Arrieta, en la dirección de la MOI. ${ }^{122}$

120 La cita y la alusión a Rol-Tanguy, en Geneviève Dreyfus-Armand, L'exil des Républicains..., op. cit., p. 155.

121 Señalada por Guylaine, Guidez en su obra Femmes dans la guerre, 1939-1945. Perrin, París, 1989, pp. 227-229, y por Margaret Collins Weitz, Les combattantes de l'ombre. Histoire des femmes dans la Résistance, 1940-1950. Albin Michel, París, 1997.

122 Neus Català, Ces femmes espagnoles. De la Résistance à la Déportation. Tiresias, París, 1994, pp. 69-74. La edición española es De la resistencia y la deportación. 50 testimonios de mujeres españolas. Adgena, Barcelona, 1984. Un estudio de la sociología de las mujeres que participaron en la Resistencia francesa, en Claire Andrieu, "Les résistantes, perspectives de recherche», en Antoine Prost (dir.), La Résistance, une histoire sociale. Les Éditions de l'atélier/Éditions Ouvrières, París, 1997, pp. 69-96. Los estudios sociológicos sobre la participación en la Resistencia francesa, tanto femenina como masculina, son elaborados sobre la base de las peticiones de cartas de CVR (Combattant Volontaire de la Résistance) después de la Liberación, a pesar de que es una fuente contestada por algunos historiadores; pero, en el caso español, no disponemos ni siquiera de un tipo de documentación semejante, por lo cual elaborar una sociología de la resistencia antifranquista es sumamente dificultoso. 
Muchas españolas, la mayoría anónimas, ejercieron funciones de enlace y encubrimiento. En las estructuras del PCE había mujeres que podían alcanzar puestos de responsabilidad en la organización política, como Carmen de Pedro, que fue durante un tiempo la máxima responsable de la delegación del Comité Central en Francia, o las oscenses Ângeles Blanco y Carmen Casas, responsables departamentales del PCE.

Sin embargo, no hemos encontrado constancia de la presencia de guerrilleras en la AGE. Es más, en Reconquista de España aparecen referencias a una "sección femenina" de la UNE, y a las funciones que le estaban destinadas: "[...] la organización de talleres para la confección de prendas para nuestros combatientes en las localidades de Toulouse y Luchon, [...] el apadrinamiento de Unidades de Guerrilleros y la colaboración tenaz en la creación de centros de reposo y colonias para nuestros compatriotas necesitados [...]». ${ }^{123}$ Funciones no muy diferentes, por cierto, a las atribuidas, también en circunstancias bélicas, a otra «sección femenina», la de FET y de las JONS. E idéntica función de apoyo y sostén material y moral se les exige cuando llega la hora de mirar hacia España: «en los instantes en que nuestros compatriotas guerrilleros efectúan sus últimos preparativos para cruzar la frontera de los Pirineos con las armas en la mano es a ellas, a nuestras mujeres, a las que corresponde realizar un trabajo infatigable de propaganda, de simpatía, de solidaridad moral y material hacia la vanguardia de Unión Nacional, hacia "Guerrilleros Españoles" ». ${ }^{124}$ Aún más explícito es un artículo titulado «Madre!!!» y firmado por Amparo, en el que se refiere tanto a las madres españolas que sufren como a la madre patria. Continúa Amparo con una alusión a los guerrilleros, afirmando que «Han pasado seis años y [...] cada día vemos más cercano ese ansiado momento de volver, pero no hay que esperar que sean sólo nuestros guerrilleros quien la liberen, las mujeres tenemos que hacernos dignas de ellos, no hemos de querer que un día ellos puedan vanagloriarse de ser ellos solos los que han liberado nuestra Madre; nosotras hemos de trabajar más y más cada día para contribuir a la Reconquista de España. Hacernos dignas de llamarnos españolas, dignas de nuestros guerrilleros. Ellos tienen su puesto en Guerrilleros, nosotras en las Secciones Feme-

123 Reconquista de España. Suplemento del Alto Garona. 15/10/44. Toulouse, 2. ${ }^{\text {a }}$ época, n. ${ }^{\circ} 2$.

124 Reconquista de España. Portavoz de la JSUN. Alto Vienne, 1/9/44. 
ninas de Unión Nacional». En el mismo número, aparece en la sección titulada «Nuestros guerrilleros» una carta firmada por varios guerrilleros de la Brigada Vasca destinada en Bayona en la que solicitan «madrinas de guerra guapas y castizas que sepan comprender nuestra causa de liberación. Abstenerse las petainistas de Vichy por muy guapas que seáis». La función a la que se destina a las mujeres es, pues, de apoyo material y moral, cuando no de mero "descanso del guerrero", en este caso del guerrillero. Los hombres al frente, las mujeres a la retaguardia: la consigna comunista de la guerra civil seguía estando vigente, y lo estaría durante toda la época de la resistencia armada, dando a la guerrilla comunista, y, por tanto, a la aragonesa, uno de sus caracteres específicos. ${ }^{125}$

Pero en diciembre de 1944, momento en el que aparecían estos artículos, la suerte de la "Reconquista de España» ya estaba echada, y para los comunistas había quedado claro que España no podía reconquistarse mediante una operación militar. En los últimos meses de 1944, los transcurridos entre la Liberación de París en agosto y la publicación de los citados artículos en diciembre, habían ocurrido muchas cosas, y la trayectoria de los guerrilleros españoles, tanto en España como en Francia, había sufrido un importante viraje. Tanto el panorama internacional como el nacional tienen mucho que ver con el desarrollo de las operaciones que se conocieron, en su conjunto, como «las invasiones del valle de Arán», y de las que vamos a tratar en el próximo apartado.

\subsection{2. «Sólo se resisten a venir los que ayer no quisieron resistir»: ${ }^{126}$ Las «invasiones» de 1944}

La Liberación de Francia produjo un efecto enfervorizador sobre los guerrilleros españoles. Muchos de ellos se dirigieron espontáneamente hacia la frontera, pero la mayoría lo hicieron encuadrados en las unidades de la AGE, que sus mandos condujeron hacia el sur. El estado de ánimo general había sido cuidadosamente preparado por la prensa comunista española durante semanas; a la euforia de la Liberación se unía el efecto de las consignas que llamaban a todos los patriotas en el exilio a la «Recon-

125 Reconquista de España. Al servicio de la JSUN. Edición Vierzon (Cher), 9/12/44, n. ${ }^{\circ} 2$, más 47 aparecidos en la clandestinidad. La cursiva es mía.

126 Reconquista de España. Al servicio de la JSUN. Edición de Vierzon (Cher), 9/12/44, n. ${ }^{\circ} 2$. 
quista de España». A partir del mes de septiembre de 1944, la prensa comunista y, en general, la prensa de la Resistencia salió de la clandestinidad y comenzó a ser publicada legalmente; la Unión Nacional y su órgano Reconquista de España aprovecharon el momento para alcanzar el máximo de publicidad y difusión. La Unión Nacional se sirvió de la coyuntura de la Liberación para presentarse como el equivalente español del Conseil national de la Résistance (que tras la Liberación fue sustituido por el Comité français de libération nationale (CFLN) como máxima autoridad en el interior), y se multiplicaron los actos públicos y de reafirmación, como la constitución de la Unión Nacional de Intelectuales Españoles (compuesta, entre otros, por Picasso, Corpus Barga, Victoria Kent...). ${ }^{127}$ También se buscaron referencias en el imaginario revolucionario de los republicanos españoles, y así, por ejemplo, se comparó la UNE con la Unió de Hermanos Proletarios (UHP) de 1934 (que resurgiría de nuevo en 1936), insistiendo en la unidad de la clase obrera. ${ }^{128}$

La prensa francesa de la Resistencia - Combat, Défense de la France, Franc-Tireur o el órgano del PCF, L'Humanité, que también salía en estos momentos de una larga clandestinidad—, se solidarizó con la causa de los guerrilleros españoles, y aceptó y reprodujo el papel que la UNE se atribuía como organismo rector y representativo de la resistencia española: para presentar a la UNE ante los lectores, la prensa francesa la define como «l'équivalant du CNR». La UNE no sólo buscaba el reconocimiento como organización de resistencia, sino que la Junta Suprema de Unión Nacional, ante la extrema debilidad de las instituciones republicanas en el exilio, quería aparecer como el órgano de representación del pueblo español, interlocutor válido frente a los Aliados, una suerte de Comité de Liberación Nacional español.

Sin embargo, el resto de organizaciones republicanas en el exilio estaba organizando otra asociación al margen del PCE para contrarrestar el peso de la UNE. En octubre de 1944 apareció el primer manifiesto de la recién creada Alianza Nacional de Fuerzas Democráticas (ANFD), organizada en el verano de 1944, que agrupaba a todas las organizaciones republicanas (es decir, socialistas, libertarios y republicanos), con excepción del

127 Reconquista de España. Órgano de la UNE en zona Norte, 30/9/44, año IV, n. 36.

128 Reconquista de España. Órgano de la UNE en zona Norte, 7/10/44, año IV, n. 37. 
PCE y otras asociaciones netamente comunistas (como la Unión de Mujeres Españolas o la Unión de Intelectuales Libres) y de los nacionalistas, y cuyo objetivo era «la creación de un gobierno democrático sobre la base de las organizaciones adheridas a la Alianza, el cual, tras haber restablecido el orden jurídico y las libertades públicas, crearía las condiciones legales y organizativas que permitieran la convocatoria de elecciones generales». ${ }^{129}$ También estableció contacto con las organizaciones de derechas no falangistas, compitiendo en este campo con la UNE, y el mismo verano inició acercamientos con los monárquicos.

En cuanto a los libertarios en el exilio, también estaban divididos respecto a su integración en la ANFD entre un sector "colaboracionista», partidario del apoyo al Gobierno republicano, y un sector apolítico liderado por Federica Montseny y Germinal Esgleas que acabará prevaleciendo en el exilio, mientras que en el interior predominaba la política colaboracionista. Los libertarios del interior no tendrán noticias de la constitución de la ANFD hasta mucho tiempo después de su creación; la noticia no apareció publicada en Solidaridad Obrera de Cataluña hasta junio de 1945, un mes después de la celebración del Primer Congreso de la CNT y el Movimiento Libertario en Francia, en el que se materializó la división entre colaboracionistas y apolíticos. En el mismo número de Solidaridad Obrera, se insistía en la necesidad de coordinar las acciones del MLE en el interior y en el exilio y en la voluntad aliancista entre la CNT y la UGT. ${ }^{130}$ Pero en el proceso que estamos describiendo los libertarios desempeñaron un papel secundario, al menos como organización, ya que su participación en los combates de la Liberación y en la resistencia interior es, cuantitativamente, muy importante.

Apenas liberada Toulouse y ocupada por fuerzas de la AGE, el 21 de agosto de 1944 la UNE hizo un llamamiento a la población para que secundara el levantamiento general contra Franco. Dos meses después, el 10 de octubre de 1944, el Comité de la UNE de los Altos Pirineos se dirigía al general De Gaulle en nombre de 5000 personas reunidas en Tarbes para pedirle el reconocimiento de la UNE como Gobierno provisional de la República española. La prensa francesa se hizo eco del mensaje que la

129 Hartmut Heine, La oposición..., op. cit., p. 248.

130 Solidaridad Obrera. Organo de la Confederación nacional del Trabajo de Cataluña. AIT. Portavoz de la CNT de España, n. ${ }^{\circ}$ 6, época V, año I, junio de 1945. 
UNE hizo llegar al general De Gaulle, en la que explicitaba sus aspiraciones tras la Liberación de Francia: «La Liberación de Francia no interesaba solamente a los franceses, sino a todos los hombres honestos del mundo que ven en vuestro país un faro potente de la civilización, del progreso y de la libertad [...]. Por nuestra parte, nosotros proseguimos en combate contra los agentes hitlerianos que oprimen nuestra patria. Izamos la bandera de la unidad y de la lucha de todos los españoles, de derechas y de izquierdas, contra el puñado de falangistas hitlerianos [...] vuestra unidad, vuestra lucha y vuestra vistoria constituyen nuestro mejor ejemplo». ${ }^{131}$ Asimismo, se recordaba que «Franco y la Falange han enviado a Francia a combatir al lado de los alemanes las fuerzas de la vergonzosa "División Azul" que vuestros soldados y nuestros guerrilleros han vencido y hecho prisioneras en los departamentos de Hérault y de Ariège [...] Vuestra liberación presagia la nuestra y, sobre ellas podremos cimentar la más fecunda de las amistades franco-españolas». ${ }^{132}$

La demanda de ayuda a los franceses para continuar la lucha es explícita. Y ésa parece ser la voluntad de algunos de los mandos militares franceses, si atendemos a declaraciones como las del comandante Lassère, de las FFI, que afirmaba en un acto convocado por la UNE en Toulouse: «Hoy estáis a nuestro lado, mañana estaremos al vuestro por la libertad de España». ${ }^{133}$ El 14 de octubre de 1944, el general Chevance-Bertin estimaba los efectivos de la AGE en unos 7000 hombres con cuartel general en Montréjeau, y finalizaba su informe añadiendo que «en el momento presente los guerrilleros son, entre las fuerzas republicanas españolas, la mejor organizada, la más disciplinada y la más fácilmente controlable». ${ }^{134}$ Este mismo general, con el cargo de comandante de las FFI de las zonas sudoeste y centro, daba en noviembre de 1944 una muestra del apoyo total que las FFI proporcionaron a la UNE cuando, ante la noticia de que "grupos de españoles armados se organizan actualmente de una manera autónoma fuera de la autoridad FFI», señalaba que "fuera de las formaciones de la UNE ninguna otra autoridad española está cualificada para la crea-

131 Défense de la France. Le grand quotidien du soir. Fondé sous l'occupation ennemie le 14 juillet de 1941, 11/10/44.

132 L'Humanité. Organe central du Parti comuniste français, 12/10/44.

133 Anónimos. Portavoz de la 26 división de la Agrupación de Guerrilleros Reconquista de España. Edición de Chalabre (Aude), septiembre de 1944, n. ${ }^{\circ} 1$

134 Jean-Louis Dufour y Rolande Trempé, «La France, base-arrière...», op. cit., p. 273. 
ción de semejantes movimientos en territorio francés. En consecuencia, los poderes públicos y la población civil no deben en ningún caso prestar su apoyo a esas organizaciones disidentes, que serán disueltas y desarmadas». ${ }^{135}$ La UNE basaba su legitimidad en la representatividad de los guerrilleros, que a su vez se habían legitimado frente a los franceses y las FFI por su participación en la Liberación. Sin embargo, también había cierta suspicacia por parte de algunos sectores franceses hacia los guerrilleros españoles; su presencia predominante en zonas del sur como la región de Toulouse daba visos de realidad a la leyenda, extendida en París por sectores hostiles a los republicanos españoles, de la «République rouge du SudOuest». ${ }^{136}$ No era, en todo caso, un problema privativo de los guerrilleros españoles; en determinados círculos se cuestionaba el poder que las FFI habían alcanzado en algunos departamentos a raíz de la Liberación.

La situación inmediata a la Liberación es difícil y confusa; una situación de cierto vacío de poder, o, mejor dicho, de confluencia de diversos poderes. Con la llegada de De Gaulle a París, la autoridad del CFLN sustituía a la del CNR, convertido en una especie de órgano consultivo, y de los Comités départamentales de Libération (CDL), órganos, tanto el CNR como los CDL, emanados de la Resistencia y legitimados por la lucha clandestina contra el ocupante y sus acólitos franceses. Pero fueron los miembros del CFLN, que ya actuaba en cierto modo como Gobierno de la República francesa en el exilio, los que formaron el Gobierno provisional de la República francesa. Y los modelos de Estado que se proponían desde el CFLN presidido por De Gaulle, por un lado, y los órganos de la Resistencia, con un importante peso de los comunistas, por otro, eran muy distintos. Los movimientos de resistencia, representados por el CNR, esperaban que tras la Resistencia y la Liberación se produjese una revolución, una revolución de orientación socialista. De hecho, según los representantes del Estado Mayor de las FFI no se podía separar el proceso de Liberación nacional de la Insurrección nacional. ${ }^{137}$ Los planes de De Gaulle para el futuro de Francia eran otros, y desde luego no consideraban la posibilidad de una revolución de esa índole.

135 Reconquista de España. Al servicio de la JSUN. Edición de Vierzon (Cher), 25/11/44, n. ${ }^{\circ} 1$.

136 Declaraciones del antiguo comisario de la República en Toulouse tras la Liberación. Recogidas por Pierre Bertaux y citadas por Geneviève Dreyfus-Armand, «Les oubliés...», op. cit., p. 37.

137 Combat, 2/9/44. 
Existía, pues, una infraestructura preparada para salir a la luz y tomar los mandos en el momento en que las autoridades alemanas y colaboracionistas desapareciesen. Una infraestructura, sin embargo, que implicaba dos fuentes diferentes de legitimidad: la emanada directamente de la participación en la Resistencia, y la que se apoyaba en la autoridad del CFLN, aunque en ocasiones los individuos concretos coincidiesen. Pero a nivel local, de cada departamento y de cada núcleo de población, había una presencia insoslayable: la de las tropas de resistentes que habían recuperado el territorio y expulsado de él a los alemanes. La existencia de los Comités départamentales de Libération, que debían reorganizar la vida local, no impidió que se produjesen situaciones en las cuales el poder efectivo y la legitimidad fue asumido por las tropas de las FFI que habían liberado cada localidad. La forma en la que se llevaron a cabo muchos de los aspectos de la depuración, proceso que comenzó de forma casi paralela a la Liberación, dan fe de este poder de los FFI, poder reconocido y refrendado por la población. En los lugares liberados por los guerrilleros españoles, o con una fuerte presencia de éstos, como era el caso de Toulouse, la autoridad en los momentos inmediatamente posteriores a la Liberación fue asumida por ellos. Una autoridad legitimada por las armas, pero también por el agradecimiento de la población liberada, que se entregará a una especie de fiesta en la que se mezclaban la celebración y la venganza contra los miembros de la comunidad acusados de haber colaborado con los nazis, señalados por sus convecinos y castigados por éstos en unión de los maquisards. Los guerrilleros, pues, se veían revestidos del poder de ejecutar las «sentencias» dictadas, en muchos casos, por una justicia popular e irregular. ${ }^{138}$

138 Acerca de la Liberación y la depuración, ver Alain Brossat, Libération, fête folle. 6 juin 44-8 mai 45: mythes et rites ou le grand théâtre des passions populaires. Autrement, París, 1994; Françoise Leclerc y MichèleWeindling, "La répression des femmes coupables d'avoir collaboré pendant l'occupation", en Françoise Thébaud (coord.), Clio. Histoire, femmes et sociétés. N.o 1: Résistances et Libérations. Presses Universitaires du Mirail, Toulouse, 1995, pp. 129-150; Herbert Lottman: La Depuración. Tusquets, Barcelona, 1998. Estadísticamente, la depuración es todavía un tema insuficientemente estudiado; en seis departamentos (Hérault, Landas, Loiret, Loira Atlántico, Lot y Garona, Oise), no existe ninguna estadística al respecto. Según los datos del Comité d'Histoire de la Deuxième Guerre Mondiale, se produjeron entre ocho mil y nueve mil ejecuciones extrajudiciales, de entre las cuales un millar, aproximadamente, tuvieron lugar a raíz de juicios celebrados por cortes marciales improvisadas o por tribunales militares de urgencia. Françoise Leclerc y MichèleWeindling, "La répression des femmes...», op. cit., p. 131, donde también se cita, en nota a pie de página, la opinión de Henri Rousso, para quien la idea de una depuración incontrolada de gran magnitud, que habría escapado del control de los organismos encargados de la depuración «legal», no se corresponde con la realidad. 
Con esto queremos señalar que también los guerrilleros españoles se vieron investidos de tal autoridad, y que asumieron el control de amplias zonas: en particular, de las que lindaban con la frontera española. Cuando los batallones de las FFI se disolvieron y se transformaron en batallones de seguridad en septiembre de 1944, es decir, tras la Liberación, los batallones controlados por la UNE siguieron su ejemplo y la AGE se transformó a su vez en varios batallones de seguridad acantonados en los departamentos de Alto Garona, Ariège y Bajos Pirineos. Las fuerzas guerrilleras pasaron a denominarse, genéricamente, Agrupación guerrillera Reconquista de España, y a partir de ellas se organizó la 204 División, al mando de Vicente López Tovar, cuya misión era atravesar la frontera española y ocupar el valle de Arán. Comienza así el corto período de triunfo de la UNE (según la expresión de Rolande Trempé), durante el cual tuvieron lugar las invasiones de 1944 y que finalizará en febrero de 1945 con la disolución de los batallones de seguridad, seguida por la de la propia UNE. En realidad, el fracaso de la UNE está ligado al del proyecto insurreccional que se había gestado en el seno de la Resistencia francesa. Aunque sobre todo tuvo que ver, claro está, con el fracaso del propio proyecto insurreccional de la UNE, el proyecto de infiltración masiva a través de la frontera española conocido como «Reconquista de España».

El tema de la fallida Operación Reconquista de España ha hecho correr ríos de tinta y ha dado lugar a una controversia de carácter más político que historiográfico, centrada en conocer los verdaderos objetivos de la operación, la intención final de su promotor (que, según las fuentes más solventes, es sin duda alguna Jesús Monzón) y si, en el fondo de la cuestión, no se trataba de consolidar la hegemonía del PCE en el seno de la oposición antifranquista..., o de una lucha por el poder dentro del propio PCE. En cuanto a las razones de su fracaso, están bastante claras y no hay mucho que discutir al respecto. Se infravaloró la capacidad de respuesta del ejército franquista por parte de los jefes de la UNE, y había un profundo desconocimiento de la situación social de España; además, hubo un exceso de optimismo al considerar la posibilidad de provocar un movimiento insurreccional, y se cometió la imprudencia de dar una notable publicidad a los proyectos militares de invasión, lo que puso en guardia a las autoridades militares españolas: el elemento sorpresa, en suma, brilló por su ausencia. En particular, Reconquista de España llevaba mucho tiempo anunciando la insurrección. Y 
los nuevos periódicos Lucha y Anónimos (creados en agosto y septiembre de 1944, respectivamente) — publicaciones dirigidas a los guerrilleros de la AGE, ahora Agrupación de Guerrilleros Reconquista de España- llevarán en las portadas de sus primeros números sendos llamamientos a la insurrección nacional. En concreto, Anónimos, que se proclamaba portavoz de la Agrupación de Guerrilleros Reconquista de España, exhortaba a sus lectores: "Con las armas perdimos España, ha de ser con las armas que hemos de reconquistarla. ¡Adelante por la Insurrección Nacional!». ${ }^{139}$ Como indica D.W. Pike, es imposible que las autoridades franquistas no estuviesen al corriente del asunto. ${ }^{140}$ Vicente López Tovar, jefe de la Operación Reconquista de España, es de la misma opinión. En sus memorias inéditas, relata su escepticismo cuando le fue confiada la operación y sus fuertes críticas a las personas que en aquel momento ostentaban la dirección del PCE en Francia, y de las que partió la iniciativa de la operación:

[...] Me puse en contacto con el Coronel Calvetti Jefe de la zona fronteriza y amigo mío, el cual ya estaba informado de la operación, me aconsejó no hacerla, pues todo el mundo estaba informado de ello.

El Comisario de la República de Toulouse Sr. Pierre Bertaux.

El Coronel Victor de la Seguridad Territorial.

El Servicio de Contraespionaje francés.

El 2. ${ }^{\circ}$ bis español, y por consiguiente los generales Yagüe y Moscardó, yo agradecí a Calvetti sus informaciones y su lealtad vis a vis de los republicanos españoles.

A la siguiente reunión con la Agrupación, vino conmigo mi jefe de E.M. Álvaro y un oficial Mamés Grafias, nos encontramos con el responsable del Partido en Francia, completamente desconocido por mí, un tal Mariano [se trataba de Jesús Monzón], y algunos que se titulaban miembros de la Comisión de Trabajo, entre ellos Azcárate, Sánchez Biedma, Manuel Gimeno, Carmen de Pedro, así como el fantástico General Luis y su jefe de E.M. el coronel Acevedo y el comandante Miguel Ángel Sanz, en compañía del general César y del comisario que me tenían destinado, Joaquín Yufera.

Todas estas personalidades politico-militares, son las que decidieron de la muerte y de la prisión de cientos de republicanos españoles, en una operación descabellada y sin ninguna perspectiva de éxito; en contra de la opinión de la mayoría de oficiales de la guerra de España y principalmente de mi E.M.

139 Anónimos. Portavoz de la 26 división de la Agrupación de Guerrilleros Reconquista de España. Edición de Chalabre (Aude), septiembre de 1944, n. ${ }^{\circ} 1$.

140 D.W. Pike, Jours de gloire, jours de honte. Le Parti Communiste d'Espagne en France depuis son arrivée en 1939 jusquà son départ en 1950. CDU y SEDES, París, 1984, p. 118. 
[...] No se tuvo en cuenta para nada ni se consultó a ninguno de los Jefes militares que luchaban en las diferentes provincias francesas. ${ }^{141}$

Estos dos últimos párrafos, a nuestro entender, revisten un gran interés, pues, dejando de lado la más que posible parcialidad de Tovar respecto a sus superiores políticos, dan cuenta de una muy probable disensión en el seno del PCE entre "políticos» y «militares», entre quienes sopesaban el alcance político de la operación y los más cualificados para calcular su coste militar. Una división que se produce en el seno de otras organizaciones clandestinas que recurren a la lucha armada.

Pese a estas posibles reticencias, la orden de ataque fue firmada el 16 de octubre por Vicente López Tovar, nombrado comandante en jefe de la 204 División de Guerrilleros, que reagrupaba a las fuerzas de la UNE divididas en doce brigadas. Se trataba de 4000 hombres según D.W. Pike, o 5000 según Daniel Arasa. Y, excepcionalmente, varias mujeres, de las cuales sólo conocemos algunos nombres: la madrileña Pilar Vázquez (que, al parecer, también había participado en la batalla de la Madeleine), la parisina Sonia Niel, la oficial Consuelo Carriedo, Carmen, Dolores, Rosario, Ramona y Roser Giménez. ${ }^{142}$ Varias brigadas penetraron por diversos puntos del Pirineo navarro y aragonés, mientras que el grueso de los guerrilleros entraba en el valle de Arán el día 19 de octubre. Pero estas tropas no llegaron a rebasar la altura de Viella, donde les esperaba un nutrido contingente de tropas franquistas al mando de los generales Yagüe, Moscardó y Monasterio. Según la versión oficial dada por el PCE, la operación fue detenida por Santiago Carrillo, que había vuelto de su exilio soviético pasando por el norte de África y se presentó en la frontera para ordenar la retirada inmediata de las tropas cuando todo estaba ya perdido. ${ }^{143}$ También la decisión de Carrillo, que le valió posteriormente un notable prestigio por haber, supuestamente, «salvado» a los guerrilleros de una matan-

141 Vicente López Tovar, Biografía de Vicente López Tovar. Coronel de los guerrilleros españoles en Francia. 1992. Mecanografiado. Agradezco a Jesús de Cos, que me haya permitido consultar y reproducir este documento excepcional.

142 Ferrán Sánchez, El maquis a Catalunya..., op. cit., p. 222.

143 Los datos oficiales fueron 588 bajas entre los guerrilleros (129 muertos, 241 heridos y 218 prisioneros) y 248 bajas en el ejército franquista, entre ellas 32 muertos. Muchos de los guerrilleros apresados fueron fusilados posteriormente en Zaragoza. Los datos son aportados por Francisco Moreno en Santos Juliá (coord.), Victimas de la guerra civil. Temas de Hoy, Madrid, 1999, p. 373. 
za segura, es objeto de polémica, pues tanto Vicente López Tovar como otros jefes militares, como Emilio Álvarez Canosa, Pinocho, veterano de la guerra de España, en la que combatió junto al Campesino, y de la Resistencia francesa, afirmaron posteriormente que cuando llegó Carrillo ellos ya se habían «retirado» por su cuenta. Por tanto, la decisión de la retirada no fue una decisión política, sino que partió de los militares que estaban al mando de la operación.

El testimonio de Pinocho, comandante de la Brigada 471, acerca de la invasión es especialmente crítico. A semejanza de Tovar, recuerda la «invasión» como una operación suicida, sin apenas preparación ni estrategia militar a seguir, y afirma que Franco estaba al corriente de la operación y había realizado en la zona una política de "tierra quemada", alejando a los campesinos y dejando vacías las poblaciones. Una táctica, por cierto, que se empleará posteriormente durante la lucha contra la guerrilla.

Antes de la Liberación, la Unión Nacional había decidido llamar a la insurrección nacional. Franco estaba al corriente. En la Unión Nacional —de tipo militar - estaban los guerrilleros de Tovar y compañía. Yo no estaba con ellos. En el 42 me fui de aquí al maquis de la Dordogne [un maquis de las FFI] y allí fuimos contactados por Tovar, que era un jefe mío en España que mandó la 46 División, después del Campesino, y me dijo: «Pinocho, no es aquí donde tienes que estar combatiendo contra los alemanes. Es en España. El pueblo español está esperando un chispazo que provoque la rebelión porque hay mucho malestar en el ejército español entre los generales»... a lo mejor era verdad [...] el servicio de espionaje alemán sabía que Franco estaba tambaleándose. Lo del valle de Arán sirvió para fortalecerlo. Provocó la unión del ejército franquista. Lo que hicimos fue el indio. Fuimos manipulados. Eso de que el pueblo español se sublevaría al ver las guerrillas, ¡coño, sí! ¡Sublevarse! Por donde entré yo, por el Esterri d'Aneu, nos pegaron una paliza el primer día que janda!... Mandé a un grupo a hacer saltar un puente. Saltaron el puente, pero no hubo ninguno que volvió. Yo no sé si fueron muertos, heridos, prisioneros o se infiltraron por ahí. Eran doce. No sé dónde pasaron. No volvieron. Yo no sé si murieron [...].

Franco sabía que íbamos a pasar y por dónde porque lo gritábamos a voces. No había muchos pasos. Tovar pasó por Las Bordas y nosotros por Louleben y caer sobre el lago de Campirme hacia Tremp. No encontramos resistencia alguna porque los franquistas se habían retirado $70 \mathrm{~km}$ y habían hecho la tierra quemada: no había ni un rebaño ni nada para comer. Todos los campesinos para atrás. Nos dejaron entrar. Teníamos que ir en fila india y se nos puede contar fácilmente [...]

Nuestra misión: infiltrarse lo más lejos posible. Infiltrarse. Nada de guerra de trincheras. Entrar en España y crear psicosis de guerrilla [...] En 
esa psicosis creíamos nosotros que era verdad lo que decía el Partido de que el pueblo español esperaba el chispazo. ¡Joder con el chispazo! Entre el somatén, los falangistas, la policía armada, el Tercio... y todo, todo contra nosotros. ${ }^{144}$

Mucho menos amargo, e incluso indulgente (aunque también reprobador desde el punto de vista militar), es el testimonio del guerrillero Germán Amorrortu, Manso. Este guerrillero, militante comunista desde 1936, pasó la frontera en el 44 con un grupo de 80 hombres. Posteriormente, será un destacado guerrillero de la Agrupación Guerrillera de Levante y Aragón, ocupando en ésta puestos de responsabilidad. El testimonio que citamos pertenece a un informe que Manso redactó para la dirección del partido, fechado probablemente en 1947:

Mi punto de vista político, con relación al interior, pienso que aquello sirvió para hacer revivir el odio que sentía nuestro pueblo hacia el franquismo a la vez que abrió la perspectiva para desarrollar la lucha demostrando a nuestro pueblo que no estaba él solo, sino que junto a él estaba toda la humanidad progresiva. En el terreno internacional, también pienso que nos favoreció algo. En el aspecto militar pienso que fue una cosa descabezada ya que el pueblo no estaba preparado; había un terror enorme; no había organización y el Ejército franquista contaba con medios para destrozar a todas las fuerzas que estaban preparadas para entrar; lo único que se consiguió fue el perder una cantidad de cuadros enorme que podía haber dado un buen rendimiento después [...]. Después de comunicarnos cómo habíamos de pasar la frontera y las tareas a realizar, cada uno expuso su punto de vista y a pesar de que algunos camaradas y yo también expusimos que se debía de escoger a la gente y formarla en grupos pequeños de diez personas, lo máximo, nos enviaron en un grupo de ochenta, entre los que había gente casi inútil y que estaba cegada por la victoria, pero que cuando vieron la realidad, se volverían, como así sucedió. En el primer combate contra una Bandera del Tercio, que duró desde las 9 de la mañana hasta la noche, ya perdimos la mitad que se volvieron a Francia; el resto se fugó; muertos no hubo ninguno, que sepamos. ${ }^{145}$

El informe de Manso es muy interesante porque, desde la perspectiva de 1947 y de su militancia en las guerrillas del interior, achaca a las invasiones del valle de Arán errores que posteriormente se repetirían en la gue-

144 Entrevista, Emilio Álvarez Canosa. Greasque (Francia), 8 de octubre de 1996. Entrevista realizada y transcrita por Eutimio Martín, a quien agradezco su amabilidad por permitirme su consulta y reproducción. Hay que señalar que, posteriormente, tanto López Tovar como Pinocho fueron relegados por la cúpula comunista.

145 Autobiografía de Germán Amorrortu, Manso. Archivo del Comité Central del PCE, sección Movimiento Guerrillero, informes sobre camaradas, sign. 621-622. 
rrilla, sobre todo la pérdida de cuadros valiosos y con una gran formación política, que fueron sacrificados a una estrategia militar errónea y basada en una información falsa acerca de la situación en el interior. Este desfase entre la información que llegaba a la dirección comunista en el exilio y la realidad del interior de España es un defecto que la clandestinidad comunista arrastrará durante muchos años.

Sin embargo, Amador Martínez, comunista asturiano que también estuvo en el valle de Arán, defiende los planteamientos del PCE y la viabilidad de la operación, que, según él, nunca fue concebida como una «invasión». Declara que en las reuniones previas a la operación nunca se habló de «invasión», sino que se trataba de ocupar el valle de Arán para establecer en este territorio un Gobierno provisional de la República en suelo francés. Según este informante, nunca se planteó seriamente que fuera a producirse una insurrección popular, ni que el ejército o la clase obrera se fueran a sublevar. Se trataba de una operación militar para la que, además, se contaba con el apoyo de las unidades francesas de las FFI: según Martínez, los jefes franceses se ofrecían para luchar contra Franco, y también los yugoslavos y la URSS prometían hombres y armas. Es cierto, continúa, que tampoco hubo un análisis profundo de la cuestión por parte del PCE, puesto que en ese caso tal vez no se hubiese planteado la operación. ${ }^{146}$ Previamente, además, desde 1943, se habían enviado grupos de hombres al interior para "captar el ambiente», grupos de los que formaba parte el propio Amador Martínez. Existían también los llamados "grupos especiales», con base en Francia, que se infiltraban en el interior para llevar a cabo misiones concretas, como la voladura de la central eléctrica de Laspuña (Huesca). ${ }^{147}$ Para Pinocho, por el contrario, se trataba de una operación de prestigio del PCE y sobre todo de Jesús Monzón, que deseaba hacerse con el control del partido en Francia.

Los aspectos tácticos y militares de la operación han sido ya largamente comentados por otros autores. ${ }^{148}$ Lo que nos interesa resaltar aquí es,

146 Entrevista, Amador Martínez. París, 17 de febrero de 1998. Entrevista sin grabar. Notas.

147 Testimonio de Pedro Galindo. Santa Cruz de Moya (Cuenca), 3 de octubre de 1999. Notas.

148 La monografía más completa sobre el tema del valle de Arán sigue siendo la de Daniel Arasa, Años 40: los maquis y el PCE. Argos Vergara, Barcelona, 1984. También es bastante completo, desde esta óptica descriptiva, el trabajo de Fernando Martínez Baños, Vida 
sobre todo, la repercusión que los hechos tuvieron en la opinión pública, tanto española como francesa; cómo se enmarcan en la lógica de las acciones que se desarrollaron durante la época de la Liberación, y qué consecuencias tuvieron para la lucha armada en el interior de la península, así como en la política de los exiliados españoles. La invasión fue un fracaso desde el punto de vista militar, pero también es cierto que, en la prensa francesa surgida de la Resistencia, los hechos acaecidos en la frontera pirenaica recibieron una cobertura y una atención excepcionales, y que estos medios aprovecharon para hacer una amplia publicidad de la UNE y sus objetivos.

Contrariamente a lo afirmado por D.W. Pike, ${ }^{149}$ la operación llevada a cabo por los guerrilleros españoles sí tuvo eco en la prensa francesa, principalmente en la que surgió de los movimientos de Resistencia que componían los Mouvements unifiés de la Résistance (MUR), cuyo órgano rector era el CNR, además de aparecer en L'Humanité, el órgano oficial del PCF. Fue éste el primero en comunicar a sus lectores que se estaban produciendo combates en Cataluña entre fuerzas guerrilleras españolas y tropas franquistas. Para acentuar el apoyo de la opinión pública a las acciones de los guerrilleros, L'Humanité insistía en que España podría ser una base de refugio para los alemanes. Y además puntualizaba que los combates de los guerrilleros españoles contra el franquismo se realizaban desde 1939, pero que a causa de la liberación de Francia éstos se habían intensificado. ${ }^{150}$ Otras noticias referentes a los guerrilleros españoles iban apareciendo desde finales de octubre de 1944 en el resto de diarios, que también informaban acerca de las medidas de carácter preventivo que el nuevo

y exilio de "otros» comunistas españoles en Francia. Una cultura de la resistencia. 1936-1975. Memoria de licenciatura. Departamento de Historia Moderna y Contemporánea, Universidad de Zaragoza, 1999. El tema es tratado también por D.W. Pike, Jours de gloire..., op. cit., pp. 119-143; Jean-Louis Dufour y Rolande Trempé, «La France, base-arrière d'une reconquête républicaine de l'Espagne: l'affaire du Val d'Aran», en Les Français et la guerre d'Espagne. Actes du colloque de Perpignan. CREPF. Université de Perpignan, 1990, pp. 261-284; Émile Témime, «Problèmes stratégiques...», op. cit.; Gregorio Morán, Miseria y grandeza..., op. cit.; o Ferrán Sánchez, Maquis a Catalunya..., op. cit., pp. 90-190, entre otros.

149 D.W. Pike, Jours de gloire..., op. cit., p. 131. Sí es cierto que el avance de los españoles sobre el valle de Arán fue publicado varios días después de producirse, y en determinada prensa de orientación netamente simpatizante de la UNE y los guerrilleros españoles. Pero, dada la tirada que llegaron a alcanzar diarios como Franc-Tireur, Combat o Défense de la France (después France-Soir), está claro que la opinión pública francesa estaba informada de las acciones de los guerrilleros españoles.

150 L'Humanité, 21/10/44. 
Gobierno provisional de la República francesa, presidido por De Gaulle, estaba tomando contra los republicanos españoles. A los españoles pertenecientes a las FFI se les prohibió estacionarse a menos de $20 \mathrm{~km}$ de la frontera (cosa que se consiguió en los departamentos de los Prineos Orientales y Alto Garona, pero no en Ariège, donde los españoles tenían el apoyo total de la dirección de las FFI), y asimismo fueron obligados a abandonar los consulados españoles que habían ocupado en la zona sur. Las relaciones entre el Gobierno español y el CFLN databan, de hecho, de finales de 1943, y De Gaulle no deseaba tener incidentes diplomáticos en la frontera francoespañola en un momento en que el Gobierno provisional acababa de consolidarse en el poder y ni siquiera había sido reconocido todavía por los Aliados. ${ }^{151} \mathrm{D}$.W. Pike cita, incluso, que un agente de enlace entre franceses y españoles llegó a amenazar a éstos con hacerlos internar en campos de concentración por los norteamericanos si los guerrilleros no se retiraban. ${ }^{152} \mathrm{Y}$, según noticias recogidas por Reconquista de España, llegó a haber, efectivamente, republicanos españoles internados por tropas estadounidenses: 56 en Le Mans, 50 en Nonan-les-Pins, 78 en Cherburgo (los tres en la zona norte), de donde salieron hacia Inglaterra. Reconquista denunciaba el caso de estos «republicanos españoles considerados como prisioneros de guerra» e internados por las autoridades militares de EE. UU. en campos de concentración para prisioneros alemanes «sin resentimiento, pero con sinceridad». Sin embargo, no tenemos modo de saber si, efectivamente, se trató de una confusión, como indica la propia Reconquista, o de alguna medida de represalia. ${ }^{153}$

Por lo tanto, tras la retirada de los alemanes del sur de Francia, había cuatro ejércitos interesados en el control de la frontera pirenaica: el ejército regular francés, el franquista, los guerrilleros de la UNE (apoyados por las FFI) y los estadounidenses, preocupados por la falta de control francés en la zona. El punto de mayor tensión era Andorra, que corría el riesgo de caer en manos de Franco tras la confusión creada por el derrumbamiento del régimen de Vichy, y la actividad de los guerrilleros se desarrollaba sobre todo en torno a las fronteras de Andorra y Aragón. Los incidentes fronterizos entre republicanos que atravesaban la frontera y tropas franquistas

151 Combat, 31/10/44.

152 D.W. Pike, Jours de gloire..., op. cit., p. 125.

153 Reconquista de España. Órgano de la UNE en zona Norte, 21/10/44, año IV, n. 39. 
amenazaban con provocar un incidente diplomático en cualquier momento. De ahí la medida del alejamiento de la frontera, recomendada por los servicios secretos franceses. También se propuso sustituir a las FFI en los puntos más conflictivos, lo que provocó cierta tensión, pues para las FFI lo que se debía hacer era reforzar su autoridad. Sin embargo, poco a poco el ejército regular, muy adicto a De Gaulle, fue haciéndose con el control y las FFI vieron constantemente mermada su influencia. Lo cual es, a su vez, un claro síntoma del nuevo reparto de fuerzas y de cómo iba a reorganizarse el Estado francés tras la Liberación. El nuevo reparto de fuerzas no favorecía los intereses de los republicanos españoles, e hizo que la posición militar de la UNE, aparentemente tan sólida, no lo fuera tanto.

A ello hay que sumar que en octubre de 1944 la guerra no había terminado todavía; aún se combatía contra los alemanes en el noreste de Francia, y, de hecho, las invasiones de los guerrilleros coincidieron con la batalla de Estrasburgo. El mismo día en que el Estado Mayor de los guerrilleros firmó la orden de invasión, el 16 de octubre, el Gobierno de De Gaulle era reconocido por España. Como afirma Rolande Trempé, a nadie, ni siquiera a la URSS, le interesaba la apertura de un nuevo frente en el sur de Francia. De hecho, Churchill y Stalin se habían reunido el 9 de octubre y habían llevado a cabo el reparto de sus respectivas zonas de influencia en los países liberados. Según dicha historiadora, Stalin era contrario a la invasión, y así se lo hizo saber al PCE. Por tanto, la decisión fue responsabilidad de Jesús Monzón, en desacuerdo con el núcleo director del PCE en Moscú, e incluso con varios jefes guerrilleros, como hemos visto, y provocada quizá por el deseo de Monzón de ganar peso político dentro del PCE. ${ }^{154}$

Los periódicos Combat, Franc-Tireur y L'Humanité informan, el 22 de octubre (es decir, tres días después del comienzo de la ofensiva) de los combates entre las tropas de Franco y los republicanos. La fuente de estas informaciones, al menos en el caso de los dos primeros, era la radio franquista, que al parecer ofrecía noticias grandilocuentes acerca del número de guerrilleros, del apoyo prestado a éstos por los Aliados y de las bajas de los republicanos. El comentario político de Combat acerca de los hechos

154 Jean-Louis Dufour y Rolande Trempé, «La France, base-arrière...», op. cit., pp. 282-283. 
está censurado, lo cual nos indica que el nuevo Gobierno francés no era excesivamente tolerante con las críticas directas a su vecino. El mismo 22 de octubre, la prensa española empieza a ofrecer vagas noticias acerca de una «infiltración comunista en la frontera de Valcarlos», en el Pirineo navarro, desviando la atención del público español del verdadero punto de conflictividad, el valle de Arán. ${ }^{155}$ Y, sólo dos días después, en España "se considera virtualmente terminada la infiltración de rojos españoles por la frontera de Navarra", añadiendo que "pretendían reclutar voluntarios para un "ejército de liberación", pero reconocen que han fracasado por falta de ambiente». ${ }^{156}$ Ciertamente, el ambiente en España no era propicio para una sublevación popular, y los guerrilleros no encontrarán el apoyo esperado por parte de la población, aunque desde la prensa editada en Francia se intentase constantemente ofrecer la impresión contraria: la de que los guerrilleros eran la punta de lanza de una verdadera insurrección popular del pueblo español contra el dictador.

Incluso el veterano Le Figaro anunciaba el día 25 que «la situación se ha agravado en España. Numerosos encuentros han tenido lugar entre tropas regulares y formaciones republicanas", y denunciaba la presencia de «millares» de alemanes entre las tropas de Franco. Casi por primera vez en la prensa francesa (cosa excepcional, dado el prestigio del diario y su tendencia política más bien conservadora) se señalaba la existencia de varios maquis activos en el interior de España, así como el hecho de que había más de un millón de españoles en prisión, añadiendo además que Franco no obtendría nunca el consenso del pueblo español. ${ }^{157}$ Era un momento de extraordinaria efervescencia política en Francia en torno a la cuestión española. Pero fue algo efímero. Cuando termine el mes, la posibilidad, si es que existió alguna vez, de un apoyo militar de los Aliados a la causa republicana habrá desaparecido. El 28 de octubre se informaba en la prensa aragonesa de la celebración de una reunión hispanofrancesa en la estación internacional de Los Arañones (Canfranc), solicitada, según esta fuente, por las autoridades del departamento de los Bajos Pirineos (colindante con la provincia de Huesca). A ella asistieron por parte española: el gobernador civil de Huesca, Manuel Pamplona; un representante del general jefe militar de

155 Heraldo de Aragón, 22/10/44.

156 Heraldo de Aragón, 24/10/44.

157 Le Figaro, 25/10/44. 
Jaca; el teniente general Laguía, jefe de la comandancia de Fronteras; y el jefe de las fuerzas militares destacadas en la zona. Por la parte francesa asistieron el subprefecto de Olorón, el comandante militar de la frontera francesa, el jefe del Gabinete Militar de la Prefectura, el comisario de policía de la zona y la secretaria general de los servicios de fronteras. En la reunión se llegó al acuerdo de pacificar la frontera y facilitar el entendimiento entre los dos países, y las autoridades francesas «reprobaron [...] la actuación de los rojos españoles en el sur de Francia, y auguraron medidas urgentes que serán llevadas a cabo por las autoridades francesas en plazo brevísimo». ${ }^{158}$ Las medidas, de las que ya hemos hablado, consistieron en el alejamiento de los republicanos a $20 \mathrm{~km}$ de la frontera y la obligación de desalojar los consulados españoles ocupados por tropas de guerrilleros. La ambigüedad de la posición francesa, que por una parte cubría de medallas y honores a los combatientes españoles y por otra reprimía sus intentos de pasar la frontera, será profusamente denunciada por la prensa progresista.

Para esta prensa nacida en la clandestinidad de la Resistencia, el movimiento iniciado por los republicanos españoles era una réplica de la lucha de los franceses bajo la ocupación. En la invasión del valle de Arán veían el inicio de la liberación de España, el comienzo de un levantamiento revolucionario, y en ese sentido su tono era idéntico al de Reconquista de España. Durante los primeros días del mes de noviembre todavía se mantenía la ilusión del comienzo de una liberación española, y se realizaban amplios reportajes acerca de las poblaciones «liberadas» de las provincias de Lérida y Huesca. A la vez, se denunciaba la pasividad del Gobierno francés frente a esta situación, y se llegó a pedir una intervención francesa en apoyo de los guerrilleros españoles. Casi al mismo tiempo, la UNE celebraba un multitudinario congreso en Toulouse.

El congreso de la UNE en Toulouse se inició el 2 de noviembre de 1944, duró cuatro días y en él participaron varias personalidades que representaban, en teoría, a sus respectivas fuerzas políticas. Aunque lo cierto es que algunas de estas personas fueron repudiadas por sus formaciones políticas a raíz, precisamente, de su participación en la UNE. Así les sucedió a Julia Álvarez y a Álvarez del Vayo, del Partido Socialista, o a los cenetistas de Unión Nacional, escindidos del Movimiento Libertario.

158 Heraldo de Aragón, 28/10/44. 
También estaba presente Victoria Kent en nombre de los republicanos, pero hacía tiempo que los partidos republicanos habían desaparecido de facto. Otros participantes, como el padre Vilar, por los católicos, no parece que representasen a nadie, excepto a sí mismos. Y la representación mayoritaria correspondía al PCE. El objetivo del congreso era, según L'Humanité, «encontrar el medio de ayudar moralmente a aquellos que entienden llevar la lucha al suelo español. Hoy, se declara en los medios del congreso, el combate ya no se presenta como en 1936. Se trata de un combate por la independencia de España, de una verdadera lucha nacional». ${ }^{159}$ Será el primero de una serie de congresos, encuentros y mítines mediante los cuales la UNE pretendía rentabilizar el efecto conseguido gracias a la participación de los españoles en los combates de la Liberación y a las noticias propagadas por la prensa acerca de las invasiones a través de los Pirineos.

Pero, al fin y al cabo, la consecuencia más importante de esta fallida operacion de «invasión» fue el inicio de la táctica de infiltración de guerrilleros comunistas en el interior de España, en unos casos para unirse a grupos guerrilleros preexistentes y en otros, como en Aragón, para formar una guerrilla ex novo. En cuanto a Monzón, la maniobra fracasada fue su tumba política. En Moscú, los líderes del PCE reaccionaron con estupor ante el fracaso de la operación y, sobre todo, ante el hecho de que alguien, en este caso Jesús Monzón, hubiese podido acumular el poder suficiente para tomar una decisión de tal calibre. Dolores Ibárruri decidió que los líderes comunistas que se encontraban en la URSS y Méjico debían regresar inmediatamente a Francia para retomar el control de la situación, y todos ellos se reunieron en Toulouse. Allí se acordó que el nuevo responsable de la guerrilla fuera Santiago Carrillo, auxiliado en los aspectos militares por Enrique Líster, y la política de infiltración masiva se sustituyó por la entrada de pequeños grupos de guerrilleros bien entrenados y, sobre todo, con una buena formación política, factor que se consideraba fundamental y en ocasiones primaba sobre la formación militar. Es el comienzo de la táctica que permitirá al PCE establecer una red de agrupaciones guerrilleras en todo el territorio español, agrupaciones que en unas ocasiones convivían con organizaciones guerrilleras preexistentes y en otras se superponían a ellas o, directamente, las asimilaban. En todo caso, en Aragón, el 
mes de octubre de 1944 significa la fecha fundacional de la actividad propiamente guerrillera en la región.

El fracaso de las FFI y el CNR en su intento de imponer en Francia el modelo de Estado surgido de la Resistencia está estrechamente unido al fracaso de la UNE, pues ésta había vinculado su suerte a la de sus homólogos franceses y, sobre todo, porque el proyecto que defendían era básicamente el mismo: un proyecto revolucionario basado en la insurrección nacional, en un poder de base popular y en un Estado de carácter socialista. Por otro lado, el fracaso de la UNE consistió en no haber logrado un verdadero consenso entre las fuerzas de la oposición antifranquista en el exilio. Sólo consiguió agrupar a fracciones minoritarias de otras organizaciones; el resto de formaciones políticas se agrupará en la Alianza Nacional de Fuerzas Democráticas, en la cual el PCE acabará pidiendo el ingreso, que se hará efectivo en febrero de 1946. Sin embargo, por una parte, nos preguntamos si el fracaso es atribuible a la UNE o a la endémica división de las fuerzas republicanas en el exilio, y, por otra parte, es importante señalar que la UNE seguirá siendo, tras su desaparición, un punto de referencia para los guerrilleros del interior. Otro factor que debe tenerse en cuenta para evaluar el fracaso de la UNE es la expectación creada en torno a la intervención aliada en auxilio de los españoles; con la documentación disponible, es imposible saber si esta esperanza tenía una base real o era fruto del estado de opinión creado por las declaraciones de algunos jefes militares de las FFI y las noticias y reivindicaciones aparecidas en la prensa francesa, que daban pie a creer en un apoyo masivo de la opinión pública gala respecto a los proyectos de los republicanos.

Durante los primeros meses de 1945, la UNE insistió en sus llamamientos a la unión de todos los republicanos y en el reconocimiento del Gobierno del doctor Negrín, recientemente llegado a París, como Gobierno legítimo de la República. Pero la proximidad del fin de la segunda guerra mundial y la deriva de la política exterior de Franco hacia los Aliados restaban márgenes de acción a la UNE. Por las mismas fechas se produjo un atentado contra los locales de Falange en el distrito de Cuatro Caminos, en Madrid, llevado a cabo por un grupo de guerrilleros comunistas procedentes del maquis francés, entre los que se encontraba José Vitini, que supuso la detención y ejecución de todo el grupo y un duro golpe a la organización interior del PCE. José Vitini, veterano de la 
Resistencia francesa y teniente coronel de las FFI, fue ejecutado el 25 de abril de 1945, y su ejecución fue ocasión para manifestaciones falangistas antifrancesas. ${ }^{160}$

A principios de marzo de 1945, la UNE desmovilizó a sus guerrilleros en Francia. El secretariado de UNE en Francia hizo público un documento en el que exponía que, para contribuir más eficazmente al esfuerzo de guerra, los guerrilleros españoles se desmilitarizarían para incorporarse al frente de producción en beneficio de Francia, si bien continuaban movilizados contra Franco y Falange. ${ }^{161}$ Esto significa dos cosas: por una parte, era un reconocimiento del fracaso de la política militarista de la UNE en el interior de Francia, así como de la falta de apoyo de las fuerzas armadas aliadas; por otro, los esfuerzos militares se concentraban en el interior, que pasaba a ser el escenario primordial de la lucha. En todo caso, la UNE iba delegando en los hombres del interior el peso de la lucha armada, y esta decisión suponía un paso más en el camino que conducía a su disolución.

Finalmente, la disolución tuvo lugar a finales de junio de 1945, con la guerra mundial ya finalizada. Reconquista de España dio la noticia, insistiendo en que el Secretariado de Unión Nacional Española había acordado disolver el movimiento para facilitar la unidad de los españoles. El impulso a la lucha armada se presentaba como la justificación de la existencia de la UNE: "Los españoles que quisieron combatir tuvieron un puesto en la UNE». Y se añadía que la declaración programática de AD (la Alianza Democrática, nombre por el que se conocía a la ANFD, en la que el PCE pedirá ser admitido) coincidía fundamentalmente con los fines de la UNE, y con esta decisión se pretendía avanzar hacia la creación de la unidad nacional de las fuerzas republicanas españolas.

El foco de atención se trasladaba al interior de España. Las nuevas estructuras creadas por el PCE, y las viejas pero renovadas, eran puestas al servicio de la nueva táctica, consistente en crear una potente guerra de guerrillas en el interior de España aprovechando las ya existentes y crean-

160 L'Humanité, 25/5/45. Es muy interesante la reconstrucción que hace de este caso el escritor Andrés Trapiello, a partir del hallazgo casual del dossier de la instrucción del juicio, en el artículo "Dossier 48, caso abierto», El País Semanal, n. ${ }^{\circ} 1209,28$ de enero de 1999, pp. 136-148.

161 Reconquista de España. Órgano de la Delegación en París del Secretariado de UNE en Francia, 3/3/45. 
do otras nuevas. El 9 de mayo de 1945 la guerra había terminado; Mussolini y Hitler habían caído, y Franco seguía en el poder. Se hacía necesario desestabilizar ese poder desde el interior, ofrecer apoyo a una lucha armada operativa y canalizar el «ardor guerrero» de muchos militantes antifranquistas. Pero también se trataba de alcanzar una posición de supremacía en el seno del movimiento antifranquista. La guerra mundial había terminado, pero el fascismo no: tenía su continuidad en la España de Franco, «sede del fascismo internacional». La foto de la entrevista de Franco y Hitler en Hendaya, publicada por Reconquista de España en uno de sus últimos números con la leyenda «Lo que no podrán borrar las piruetas democráticas de Franco», era un recordatorio de que la lucha aún tenía una razón de ser. ${ }^{162}$

162 Reconquista de España. Al servicio de la JSUN, 17/5/45. 


\section{DESARROLLO Y CARACTERÍSTICAS DE LA GUERRILLA EN ARAGÓN}

\subsection{La resistencia armada en Aragón: unidad y diversidad}

\subsubsection{Consolidación de los núcleos guerrilleros (1944-1946)}

\section{Las «invasiones» en la provincia de Huesca}

Las llamadas «invasiones del valle de Arán» significaron el comienzo de la lucha armada contra el franquismo en el interior de Aragón, puesto que varios de los grupos que penetraron en España a través de la frontera oscense consiguieron infiltrarse hacia el interior y fueron los núcleos de la posterior organización guerrillera aragonesa. Por tanto, a diferencia de otros lugares de la geografía española, en Aragón la guerrilla no nació como resultado inmediato de la guerra civil. Ello se debe al desarrollo de la contienda, que, como sabemos, partió la región en dos zonas separadas por el frente de Aragón. Con el avance franquista de la primavera de 1938, los republicanos huyeron a las zonas de Levante o a Francia y no quedaron bolsas de «huidos», como ocurrió en León, Galicia, Asturias o Andalucía. La única zona donde hubo «huidos», al principio de la guerra fue la comarca zaragozana de las Cinco Villas (que comprende los partidos judiciales de Ejea de los Caballeros y Sos del Rey Católico), los cuales fueron rápidamente exterminados mediante el envío de «columnas de castigo" compuestas de militares y falangistas. Al final de la guerra también apareció otro grupo de estas características en la provincia de Teruel (concretamente, en la zona de Aguaviva), organizado por dos anarquistas de esta localidad fugados del depósito municipal de Mas de las Matas, 
José Ramiá Ciprés, el Petrol, y Fernando Castel Bernuz, el Rabós, que actuó hasta $1946 .{ }^{163}$

Bien es verdad que antes de octubre de 1944 ya se habían producido infiltraciones de guerrilleros a través de la frontera, en grupos que tenían como misión "preparar el terreno» para el posterior establecimiento de un movimiento de resistencia. Entre los comunistas que traspasaron la frontera en un primer momento se encontraba Sixto Agudo, que fue detenido en 1944 en Sevilla, poco tiempo después de su entrada en España. ${ }^{164}$ También Amador Martínez, posteriormente enlace de guerrillas en España, entre ellas de la Agrupación Guerrillera del Alto Aragón y de la zona de Levante con Francia, formaba parte del grupo que pasaba cuadros del PCE por las montañas de Ariège en $1943 .{ }^{165} \mathrm{Y}$ en junio de 1944 pasaba también para preparar la invasión Ángel Fuertes Vidosa, Antonio, aragonés de Agüero del que tendremos ocasión de hablar largamente, que formaba parte del Estado Mayor de la Agrupacion de Guerrilleros Reconquista de España y que fue el organizador de la guerrilla comunista en Teruel y Levante. ${ }^{166}$ Las infiltraciones comenzaron a ser abundantes a partir de agosto de 1944, momento en que se detectaron algunos de estos grupos en el Alto Aragón y fueron enviados por parte del Gobierno franquista los primeros grupos de tropas y policía armada a la frontera pirenaica. De principios de octubre de 1944 datan las primeras noticias de enfrentamientos entre guerrilleros y fuerzas de la guardia civil en Aísa, Echo y Benasque; el 13 de octubre hubo un tiroteo entre fuerzas de la policía armada y un grupo de guerrilleros en la zona del Hospital de Benasque, con el resultado de un guerrillero muerto. Se trataba de Elías Piquer Vicente, nacido en Caspe (Zaragoza); el muerto llevaba un brazalete con la inscripción "guerrilleros de España UN FFI». ${ }^{167}$

Como muchos de los guerrilleros que penetraron por la frontera oscense, éste era, pues, un aragonés que probablemente esperaba poder

163 Este caso está explicado con detalle en Mercedes Yusta, La guerra de los vencidos..., op. cit., pp. 100-104, y trataremos de él más adelante.

164 Sixto Agudo, Memorias (la tenaz y dolorosa lucha por la libertad, 1939-1962). Instituto de Estudios Altoaragoneses, Huesca, 1991.

165 Información facilitada por Sixto Agudo.

166 Ferrán Sánchez, Maquis a Catalunya..., op. cit., p. 229.

167 Memoria de la 223. a comandancia de la guardia civil (Jaca). Centro de Estudios Históricos de la Guardia Civil, Dirección General de la Guardia Civil. 
regresar a su población de origen. Como veremos, en general los guerrilleros trataban de acercarse lo más posible a sus localidades de origen, con el objeto de establecer lazos con vecinos y familiares, y por la seguridad que les proporcionaba el hecho de moverse en un territorio conocido. Parece que entre los guerrilleros que participaron en la operación de penetración había varios veteranos de la 43. ${ }^{a}$ División, la de la mítica "Bolsa de Bielsa», como Joaquín Arasanz. Incluso en las localidades oscenses más próximas a la frontera, algunos republicanos pasaron a Francia para unirse a los guerrilleros. Como un grupo de republicanos en libertad condicional de Echo, uno de los cuales había sido represaliado, tras el levantamiento de 18 de julio por haber tomado parte en la sublevación encabezada por Fermín Galán en Jaca en 1930. Lo cual muestra que el nuevo régimen tenía muy buena memoria, y que la «represión retroactiva» funcionaba incluso con hechos anteriores a la proclamación de la República.

Una vez comenzada la Operación Reconquista de España, a través del Pirineo aragonés penetraron en España la Brigada B (al mando de José Cortés, natural de Echo y hermano de Agustín Cortés), que entró por el paso de la Vieja; la Brigada X, formada por 400 hombres (en su mayoría, anarquistas), ${ }^{168}$ que entró el día 29 por el puerto de Urdiceto y valle de Pineta, y la Brigada 21, cuyo primer batallón penetró el 9 de octubre, que tenía como misión ocupar varios pueblos del valle de La Fueva, en el Sobrarbe. Estaba comandada por el asturiano Gabriel Pérez, y en ella se encontraba como comisario político Joaquín Arasanz, el comandante Villacampa, que posteriormente fue el guerrillero más popular del Alto Aragón y jefe de la agrupación guerrillera que se creó en la zona. Esta brigada, considerada «de elite» por haber participado en importantes operaciones durante la Liberación de Francia (como la batalla de la Madeleine), fue la única que no regresó a Francia hasta haber conseguido sus objetivos, pues ya sabemos que la mayoría de las unidades guerrilleras tuvieron que retirarse ante el enorme despliegue militar al que dio lugar la operación. ${ }^{169}$

168 Según Pedro Galindo, la Brigada X no estaba integrada en la AGE sino que actuaba de forma autónoma, aunque el Estado Mayor de la AGE conocía sus actividades. Testimonio de Pedro Galindo, Santa Cruz de Moya (Cuenca), 3 de octubre de 1999. Notas.

169 La información sobre los movimientos de las diferentes brigadas, en Daniel Arasa, Años 40, op. cit. 
Para hacer frente a la invasión guerrillera, se enviaron a la frontera altoaragonesa cuatro divisiones del ejército (la 51 y 151 en la parte más proxima a Jaca, la División 52 en el sector central del Pirineo y la 152 en la zona más próxima a Cataluña), fuerzas de la policía armada y la guardia civil (en la que destacó el papel ejercido por la guardia civil de Monzón en las posteriores operaciones de "limpieza de maquis»), e incluso se hizo venir de Cataluña un tambor de regulares. La presencia de estas tropas no se limitó al final del año 1944, sino que la militarización del norte de la provincia oscense se convirtió durante varios años en una realidad con la que la población se vio obligada a convivir. A pesar de las palabras tranquilizadoras del general Yagüe en el diario madrileño Informaciones, ${ }^{170}$ al que aseguraba que la invasión había terminado a finales de octubre y restaba importancia al asunto, lo cierto es que en febrero de 1946 todavía se temía una invasión guerrillera proveniente de Francia, a la que se unirían, según informes reservados del Estado Mayor del Cuerpo de Ejército de Aragón, tropas francesas y apoyo material proporcionado por el PCF y la SFIO. Se llegó a especular con la existencia de un ejército de 20000 hombres concentrado en la frontera pirenaica; estos informes, aunque a todas luces exagerados, debieron de tener cierto crédito, ya que tanto en 1946 como en 1947 se produjeron sendas operaciones de despliegue de tropas del Cuerpo de Ejército de Aragón "para la prevención y vigilancia de sabotajes». ${ }^{171}$ Esta psicosis se debió probablemente a que el momento era especialmente delicado para el régimen, pues en 1946 la ONU había ordenado la retirada de embajadores de Madrid, y Francia había cerrado la frontera como respuesta a la ejecución del guerrillero Cristino García.

Pero en 1944 el ejército franquista se enfrentaba a una invasión real, y varios de estos grupos de guerrilleros consiguieron, pese a la fuerte presencia de tropas, penetrar hacia el interior con desigual fortuna. La Brigada B cruzó la frontera por el paso de la Vieja, en el valle de Canfranc. Como ya se ha indicado estaba dirigida por José Cortés, cuyo hermano Agustín ocupaba el cargo de jefe departamental de Altos Pirineos en el seno de la Resistencia francesa. La brigada se fue subdividiendo y uno de

170 La entrevista a Yagüe aparece reproducida en el diario turolense Lucha (25/10/1944) y en Heraldo de Aragón (25/10/44).

171 Archivo del Gobierno Civil de Zaragoza, sección Asuntos Gubernativos, caja 103, carpeta 5 . 
estos grupos contactó en la sierra de Santo Domingo con un enlace del interior, José Barcos, a través del cual buscaron el contacto con la organización comunista de la capital aragonesa. Este grupo ocupó durante un día el pueblo de El Frago (Zaragoza). A raíz del acoso de las fuerzas del orden se fueron dispersando cada vez más, pero algunos grupos lograron llegar hasta Levante y Madrid. La Brigada X entró por Urdiceto y Pineta el 29 de octubre, cuando ya el grueso de las tropas guerrilleras se habían retirado del valle de Arán, lo que muestra cierto desfase en la actuación del grupo, ya que se supone que su misión era servir de apoyo a las fuerzas instaladas en dicho valle. Un grupo de esta brigada logró asentarse en tierras altoaragonesas, en una zona próxima a la sierra de Guara. Otros consiguieron penetrar en el interior de España, llegando incluso hasta Madrid.

Pero, como se ha indicado anteriormente, fue la Brigada 21, encargada de tomar los pueblos de La Fueva, la que más tiempo permaneció en el interior de la provincia oscense: un total de 35 días. Entraron cruzando el valle de Arán y pensaban hacer una importante recluta de adictos entre los prisioneros republicanos que eran obligados a trabajar en las obras del túnel de Viella. Allí sufrieron su primera decepción: los trabajadores salieron corriendo al divisar a los guerrilleros, y éstos sólo pudieron hablar con algunos empleados de las oficinas. El «ambiente», como indicaba la prensa franquista, no era propicio a una sublevación popular, e incluso entre los prisioneros republicanos la reacción al divisar a los guerrilleros fue de temor y no de entusiasmo; la costumbre del miedo se había instalado muy profundamente en la castigada sociedad española. Tras algunos enfrentamientos con las tropas franquistas, lograron llegar al valle de La Fueva y establecieron su cuartel general en Pallaruelo. Ocuparon hasta un total de trece pueblos, incluida Tierrantona, la población más importante del valle, y realizaron en ellos varios mítines. Después de un fuerte enfrentamiento con fuerzas del ejército en la localidad fovana de Morillo de Monclús, Joaquín Arasanz y sus guerrilleros regresaron a Francia. Según los testimonios orales, los guerrilleros tuvieron cinco muertos. Por otra parte, parece que en este grupo se encontraba la guerrillera Pilar Vázquez, a la que ya hemos nombrado como una de las escasas mujeres componentes de la 204 División. Los enfrentamientos tuvieron lugar en las propias viviendas de los vecinos, en las que los guerrilleros se habían ocultado, pero al parecer los pobladores no sufrieron daños ni represalias.

Las familias de tradición izquierdista del Alto Aragón, sin embargo, se vieron rápidamente en el punto de mira de las fuerzas enviadas a sofo- 
car las invasiones, como relata Luis Gimeno, de Echo (de donde eran también los hermanos Cortés), dos de cuyos hermanos estaban refugiados en Francia y pasaron la frontera en las oleadas de octubre de 1944:

Y las familias tenían requisiciones muy fastidiosas, a nosotros mi padre estuvo en la cárcel, un hombre que no se había opuesto nunca ni se había preocupado de nada de nada, pero en aquellas situaciones era el franquismo y mira, por tener dos hijos en Francia que estaban en el maquí y tal y cual mi padre estuvo en Zaragoza en la cárcel pero en extremo, ¿eh? que no lo picaron de churro [...] La guardia civil, mucho. Han incordiado muuucho, mucho. A nosotros nos han registrado la casa pues no te exageraré nada, pero aquel otoño del 44 igual nos han registrado la casa aquella docena de veces. Y nos miraban hasta los armarios... pensaban que ahí iban a estar. Dentro del armario iban a estar, ahí doblados como una sábana... pero no, me refiero a eso, a nosotros nos amargaban la vida, sí, mucho. Pero más que la guardia civil, bueno, la guardia civil estaba, pues sí, venía, pero eran peores todos estos otros, ¿eh? Cuando venía a hacer un registro la policía venía sin contemplación ninguna y... la famosa policía aquella secreta, que no veas. Todo esto es lo que pasó. ${ }^{172}$

El recibimiento proporcionado por la población pirenaica a los guerrilleros fue ambiguo. No hubo grandes muestras de júbilo, ni, por supuesto, homenajes como los que los guerrilleros estaban acostumbrados a recibir en las poblaciones francesas recién liberadas. Más bien hubo desconfianza y miedo, a pesar de que con los guerrilleros volvían, a menudo, viejos conocidos, familiares o vecinos huidos a Francia tras la derrota republicana, como los hermanos Cortés, los hermanos Gimeno o el propio Joaquín Arasanz. Los contingentes de hombres armados, a veces muy grandes (se llega a hablar de grupos de 300 individuos), así como los enfrentamientos que tuvieron lugar, llenaron de temor a la población, que todavía guardaba frescos en su memoria los recuerdos de la pasada guerra. Y es que el Pirineo oscense, escenario de la entrada de los guerrilleros $\mathrm{y}$ de sus enfrentamientos con las fuerzas franquistas, estaba habitado por una población dispersa en pequeños núcleos, escasamente politizada, aislada en ocasiones en valles de difícil acceso (aunque más comunicada con el exterior de lo que tradicionalmente se piensa, sobre todo a través de los canales de intercambio comercial, y de manera especial con los valles de la vertiente francesa). En todo caso, era una población compuesta mayoritariamente por pequeños e ínfimos campesinos, pastores y ganaderos,

172 Entrevista, Luis Gimeno. Echo, 8 de mayo de 1999. 
sin tejido industrial, poco afectada por la conflictividad social de la República o por la propia guerra. Hubo algunos conflictos producidos por la Ley de Arrendamientos de 1935, que dio lugar a numerosos desahucios, pero lo que más había afectado a estas poblaciones había sido la represión de posguerra y el control al que fueron sometidas por parte de los sectores más poderosos socialmente, en connivencia con los vencedores del conflicto civil. Sin embargo, en las poblaciones con algún tipo de actividad industrial, como Echo (donde había una serrería) sí existía, al parecer, una alta tasa de sindicación, y la inmediata posguerra se vivió con el temor a una represión, de la cual se sabía que presentaba un marcado carácter de clase:

Eran los dos sindicatos que había. Pero estaban en condiciones. Aquí mandaron, sería de Huesca sería de Zaragoza, mandaron delegados, un delegado de sindicatos de UGT y otro de CNT. Y es el que se encargaba de organizar la CNT. Y estaban todos sindicados. Si no en un sindicato en otro, estaban todos organizados. Y el 18 de julio, pues gracias a tener la frontera a dos pasos, que si no hubiera habido aquí una mortandad tremenda. La gente sindicada en aquel tiempo lo que pasaba entonces, que eso lo supimos luego. Entonces nada, un quítame allá esas pajas, por pertenecer a tal o por pertenecer a cual o por ser familia. El 18 de julio mataron así a muchos seres, a muchos seres mataron. Y Echo fue uno, y gracias a Dios no hubo nada, pero fue porque escaparon. ${ }^{173}$

Nos detenemos en este testimonio para explicar la reacción de la población ante la entrada de los guerrilleros, marcada por una pasividad achacable, por una parte, al miedo de la inmediata posguerra, y, por otra, al deseo de que, finalmente, se restableciera una normalidad que les permitiese continuar sus labores cotidianas y que parecía que no acababa de llegar nunca. La población pirenaica recuerda los meses comprendidos entre el otoño de 1944 y la primavera de 1945 como una época especialmente conflictiva y difícil, y el sentimiento predominante parece ser el temor, el deseo de que las cosas se «normalizaran» (dentro de una anormalidad que se había convertido en norma) y el escepticismo respecto a la efectividad o las posibilidades de éxito de la acción de los guerrilleros. No hace falta decir que este escepticismo puede estar influido por la manera en la que, finalmente, se desarrollaron los acontecimientos:

173 Entrevista, Luis Gimeno. Echo, 8 de mayo de 1999. Efectivamente, y según el recuento publicado en Julián Casanova y otros, El pasado oculto..., op. cit., en Echo no hubo muertos por la represión franquista de la guerra y la inmediata posguerra. 
Vinieron, estuvieron allí dos, entraron, estuvieron allí contando aventuras que, que aquello ni un chiquillo las hubiera contado porque para qué nos estaban contando a nosotros que porque en esta zona tuviera cuatro pueblos dominados o más bien casas solitarias, ya no más faltaba la voz de mando para apoderarse de España. Que ya tenían esta aldea, porque hay muchos pueblos que... nosotros, éramos tres vecinos que pertenecemos al pueblo ese, todos estábamos [...] y estuvieron allí contando cosas como más o menos expliqué [...] Tuvimos que hacer lo mismo que hizo el vecino, tuvimos que intervenir, prepararles la cena, y cenaron allí contando cuatro tonterías de lo que hacían ellos, que si ya tenemos dominado este barrio, que si ya tenemos dominada aquella casa, todas esas cosas, y nosotros callar y darles la razón. Y ya se fueron y ya no vimos más... yo por lo menos no. Los otros no sé si continuarían, pero yo tenía mis faenas y no tenía que cuidarme de lo de ellos. ${ }^{174}$

El mismo escepticismo, salpicado de cierta sorna montañesa, se desprende del testimonio de un hombre de ochenta y ocho años en cuya pequeña aldea, Gallisué, se instaló por unos días en octubre de 1944 un nutrido grupo de guerrilleros:

[...] [Los guerrilleros] Nos adecían que si nos parecía imposible de que hubieran podido venir, digo no, digo no hay nada imposible [...] de mítines ni nada no... lo que decían, pues... que... dicen, «mañana vendrá toda la aviación, que tapará el sol»... ¿ ¿los has visto tú? [risas] Tiene cojones... «Ya verán mañana aquí ustedes»... Hombre, bueno, bueno, pues qué ibas a hacer... darles la razón... pues yo no he visto ninguno... ${ }^{175}$

También relata cómo los guerrilleros obligaron a varias personas de la aldea a ejercer de guías para ellos. Pero, cuando aparecieron las tropas franquistas en persecución de los grupos de guerrilleros, los pobladores se vieron obligados a ejercer idéntica función. Y al igual que habían tenido que alimentar a los grupos de guerrilleros, tuvieron que suministrar comida a las tropas enviadas para perseguirlos. En suma, además de los efectos de la represión derivada de la invasión guerrillera, o el temor a los tiroteos, o a verse atrapados en los encuentros entre guerrilleros y tropas, los pobladores pirenaicos se vieron obligados durante el final del año 1944 (y durante mucho tiempo después) a ponerse al servicio de unos o de otros y participar en un conflicto en el que se les requería desde ambos lados, un conflicto que, en general, y a no ser que tuvieran lazos con alguna de las partes, les resultaba ajeno, al menos en esta primera fase, antes del establecimien-

174 Entrevista, A.S. Aínsa, 12 de agosto de 1998.

175 Entrevista, A.V. Guaso, 11 de agosto de 1998. 
to en la zona de grupos estables de guerrilleros. Y también hay que señalar que fue esta época la de mayor actividad guerrillera en la provincia de Huesca, y el momento en la que la población sufrió una alteración más directa y visible. A partir de las «invasiones», las acciones guerrilleras dejarían poca huella en la provincia, pero no las actividades represivas de las autoridades, que pasaron a ser el mayor motivo de trastorno para los altoaragoneses. Además, la escasez de acciones propiamente guerrilleras hizo que la población, en general, no se sintiese amenazada por los guerrilleros. En Huesca, pues, no se produjo una división de la población semejante a la que tuvo lugar en Teruel, donde los alineamientos junto a o contra la guerrilla ahondaron unas divisiones que la guerra civil ya había hecho muy profundas. En el Pirineo, y en general en la provincia de Hues$\mathrm{ca}$, las fracturas no estaban tan marcadas, y los enfrentamientos de posguerra no se vivieron con la virulencia extrema que sacudió a las tierra turolenses.

Volviendo a los enfrentamientos entre guerrilleros y tropas franquistas, durante el otoño de 1944 hubo encuentros entre los guerrilleros y las fuerzas del orden en las poblaciones altoaragonesas de Borau, Siresa, Aratorés, Cuellos de Lenito, la Mina, Campanil, Hospital de Benasque, Tiermas, La Renclusa, Aragüés y Escalé en octubre de 1944, y durante el mes de noviembre se observaron grupos de maquis en Espés, Nerín, Güell, Isaba, Vitaller, Denuy, Ardate, Las Lagunas, Benifons, Castaneda, Binéfar, Estopiñán, Santa Cilia de Jaca, Cerler, Fantova, Sierra de San Juan de la Peña, Anzánigo y alto valle del Ara en dirección a la sierra de Guara, así como en poblaciones de las Cinco Villas (provincia de Zaragoza). ${ }^{176}$ Los enfrentamientos continuaron también a principios de 1945, con la persecución y acorralamiento, por parte de las fuerzas represivas, de los grupos que habían conseguido penetrar hacia el interior del país. El último grupo en ser enviado a Aragón en el año 44 fue el conocido como grupo Rosa, reclutado en Pau en noviembre de 1944 y formado por 14 guerrilleros. El destino de este grupo era Zaragoza, y ya no formaba parte de la abortada Operación Reconquista de España sino que inauguraba la política carrillista de enviar pequeños grupos al interior con el objeto de contactar con las organizaciones de resistencia locales y reconstruir el PCE. El grupo

176 Fernando Martínez de Baños Carrillo, Vida y exilio de "otros» comunistas españoles en Francia..., op. cit. 
entró por Ochagavía, pero al mes de entrar ya tuvieron un encuentro con la guardia civil cerca del pueblo de Luna. El encuentro se saldó con 12 detenciones, y cinco de estos guerrilleros fueron fusilados en Torrero en febrero de 1946. Escaparon dos guerrilleros, uno de los cuales, Francisco Morcillo Jarabo, llegó a su destino, Zaragoza, donde se incorporó al PCE clandestino y llegó a ser secretario político del PCE de Aragón, Rioja y Navarra. ${ }^{177}$ En la provincia de Zaragoza, por lo tanto, no existió apenas organización guerrillera, descontando grupos aislados; la actividad desarrollada por el PCE estuvo encaminada a reconstruir el partido en la capital y algunos núcleos de población, y, eso sí, se mantuvo contacto con varias organizaciones guerrilleras, que el PCE no concebía como grupos independientes sino como estructuras de apoyo a la reconstrucción de la organización política.

En cuanto al Movimiento Libertario en Aragón, parece ser que no desarrolló una política guerrillera, a pesar de que en la Operación Reconquista de España entraron bastantes guerrilleros anarquistas y de que los primeros grupos que se formaron en el interior estaban compuestos en su mayoría por libertarios (lo cual no es sorprendente si consideramos la importancia tradicional de la CNT en Aragón). Cuando se produjeron las «invasiones», en el interior se habían reorganizado algunos grupos libertarios, concretamente en Ariza, Caspe, Fraga, Alcañiz y Valderrobres. Al paso de los guerrilleros hubo una reunión general en el pueblo de Ariza, donde la reorganización había corrido a cargo de Ramón Remacha, para discutir si se unían o no a los guerrilleros; finalmente decidieron mantenerse al margen, aunque colaboraron con los grupos de guerrilleros en retirada facilitándoles el paso del Ebro. Algunos de estos guerrilleros, sin embargo, prefirieron seguir hacia el interior y establecer guerrillas en los montes de Beceite, el Maestrazgo o en la zona minera de Utrillas. ${ }^{178}$ Allí se encontraron con otros grupos de procedencia comunista; finalmente fueron absorbidos por la organización guerrillera que el PCE creó a partir

177 Paloma Fernández Pancorbo, «La guerrilla en Zaragoza y Huesca», en El movimiento guerrillero de los años cuarenta..., op. cit., p. 75.

178 Ramón Rufat, "La reconstrucción de CNT-ML en el interior después de la guerra», en La oposición libertaria al régimen de Franco. Memorias de las III Jornadas Internacionales de Debate Libertario. Fundación Salvador Seguí, Valencia y Madrid, 1993, pp. 159-209, Archivo del Gobierno Civil de Zaragoza, sección Asuntos Gubernativos, caja 102, carpeta 6-3. 
de estos grupos y otros enviados desde el exterior, y no recompusieron una organización genuinamente libertaria.

La falta de reconstrucción anarquista corresponde, por un lado, a la pasividad de la organización y su desconfianza hacia la opción de la lucha armada, que muchos de sus militantes habían tomado como único medio de supervivencia. La desconfianza de la dirección anarquista respecto a la táctica de la lucha armada adoptada por los comunistas se trasluce en el Dictamen del Comité Regional y de la Federación Local del Movimiento Libertario intervenido por la policía en marzo de 1945 en Barcelona, que, aunque referido a Cataluña, nos sirve para analizar la posición oficial de los dirigentes del MLE en el interior. Tras una exposición de la táctica que debían adoptar los anarquistas catalanes para la reconstrucción de la CNT, se reconocían la existencia de núcleos de huidos, y se posponía el contacto con ellos a un momento posterior y más favorable: «Merece atención especial el contacto, relación (y a ser posible control), de los núcleos que existen en las montañas de Cataluña de emboscados huidos de campos de trabajo, fugitivos de otra naturaleza, que representan un potencial utilizable en cualquier circunstancia de emergencia. A tal fin se procurará llegar a los grupos de refugiados de Montseny, de Prades y de las sierras de Caballs, influenciándolos en lo posible para que pongan estas "guerrillas" al servicio de la Acción Revolucionaria cuando llegue el momento estableciendo enlaces permanentes o periódicos con los mismos y recogiendo cuanta información sea posible para su justa apreciación y posterior utilización». Posteriormente, refiriéndose a las infiltraciones comunistas, puntualizaban: «Exigen atención especial las infiltraciones de agentes comunistas a través de la frontera y por distintas comarcas de Cataluña con propósito no bien conocido y tal vez no concordante con las necesidades del momento. Será preocupación de Defensa el procurarse información de las actividades de los mencionados Agentes, para lo que puede apelarse a los mismos emboscados con los que los llamados "maquis" se han puesto en contacto». Por lo tanto, no existía por parte anarquista la voluntad de organizar un movimiento de resistencia armada que sí manifestaría el PCE, y la actitud de la dirección libertaria tendía más bien a reorganizar sus fuerzas dispersas y esperar hasta ver el giro que tomaban los acontecimientos. ${ }^{179}$

179 AHPT, sección Gobierno Civil, caja 1130, carpeta 118. 
Pero, como veremos, la hegemonía del PCE en el movimiento armado también impidió por todos los medios la reconstrucción de las organizaciones anarquistas. A diferencia de la opción pluralista seguida por otras organizaciones guerrilleras, como la Federación de Guerrillas de LeónGalicia, la guerrilla aragonesa (en su organización, que no en su composición) tuvo desde su origen un único color ideológico y propuso una sola estrategia, la marcada por el Partido Comunista.

\section{La guerrilla en Teruel y el origen}

de la Agrupación Guerrillera de Levante y Aragón

A pesar del acoso de las fuerzas franquistas, varios grupos de guerrilleros consiguieron instalarse en territorio aragonés; los que pudieron, intentaron llegar a las montañas del Maestrazgo, zona abrupta y particularmente apta para establecer bases guerrilleras; otros grupos se instalaron en la sierra de Guara o en la de Santo Domingo. En general, observamos una marcada tendencia de los jefes de grupo a asentarse cerca de sus lugares de origen, para aprovechar los contactos con amigos, vecinos o parientes y para beneficiarse de su conocimiento del terreno. Esta tendencia manifestó Joaquín Arasanz, natural de La Fueva, donde penetró con la Brigada 21 y que sería posteriormente escenario de su actuación como guerrillero, o Ángel Fuertes Vidosa, Antonio, que también había entrado en España en el marco de la Operación Reconquista de España. En principio, éste quiso instalarse en las sierras de Agüero, su pueblo natal, aunque tuvo que desistir de su proyecto en diciembre de 1944 debido a un encuentro con miembros de la guardia civil y el somatén que costó la vida a tres de ellos: un brigada de la guardia civil, el jefe local del Movimiento, Leoncio Borao Pérez, y el guardia forestal José Balio Gracia. A causa de estos hechos y de la persecución que desencadenaron, Antonio huyó a Zaragoza, donde permaneció oculto y ocupado en la tarea de reorganizar el PCE, y posteriormente se trasladó a las montañas del Maestrazgo para organizar la Agrupación Guerrillera de Levante y Aragón. ${ }^{180}$ Mientras tanto, otros grupos habían conseguido ya instalarse en este territorio. Uno de ellos era el comandado por Delicado, antiguo comandante de las FFI, que había entrado en España en la oleada de octubre del 44 por la pro-

180 Heraldo de Aragón, 31/12/44. 
vincia de Lérida y, debido al acoso de la guardia civil, decidió descender a la provincia de Teruel. Allí el grupo se subdividió y una parte, al mando del guerrillero Serrano, ${ }^{181}$ se instaló en la partida del Carmen, en Mosqueruela, donde recibía ayuda de la población e incluso se les unió algún vecino, por ejemplo los hermanos Vicente Zafón, militantes cenetistas.

Durante el verano de 1945 los guerrilleros se ocuparon simplemente de sobrevivir. En la zona de Morella, a la que un grupo se trasladó en misión de reconocimiento, contactaron con el grupo de José Borrás, Cinctorrá, natural del pueblo de Cinctorres y de ideología anarquista. No sabemos de dónde provenía este guerrillero, que permaneció muchos años en el monte, aunque parece que había entrado también en España en 1944 (sobre todo, porque no hay ninguna traza de una actividad anterior). También contactaron con otro grupo llamado del Zapatero y se les unieron individuos, como Asturias, Paisano y Frasquito, "que andaban perdidos desde la frontera». El grupo, incrementado con los nuevos ingresos, estableció otra base cerca de Pitarque, zona en la que también contaron con el apoyo de la población (entre la que había muchos cenetistas, como en Mosqueruela). Ambas poblaciones, Pitarque y Mosqueruela, proporcionarían a la AGLA varios guerrilleros. Con la llegada del invierno y la nieve los hombres de Delicado abandonaron esta zona, demasiado dura, y se trasladaron a la de Aguaviva, donde es posible que tuviesen alguna relación con el grupo del guerrillero anarquista Petrol; de hecho, parece ser que éste se les unió más tarde. El grupo de Delicado fue uno de los grupos con los que contactará Antonio. ${ }^{182}$

En septiembre de 1945, la dirección del PCE en Francia envió al interior el denominado Grupo de Guerrilleros I de Aragón, al mando de Doroteo Ibáñez Alconchel, de Azuara (Zaragoza). El grupo estaba compuesto por León Quílez Quílez, Luciano Mamilo Muñoz, Antonio Arda-

181 Se trata, probablemente, de Daniel Ortín Ayora, natural de Pitarque, hecho que explicaría en parte la rapidez y facilidad con que los guerrilleros llegaron a contactar con la población local. Entrevista, informante anónimo (hombre de sesenta y ocho años). Rubielos de Mora, 1 de agosto de 1999 (entrevista realizada en colaboración con José Giménez Corbatón).

182 Informe de Carlos sobre la AGLA desde octubre de 1944, Archivo del Comité Central del PCE, sección Movimiento Guerrillero, Equipo de pasos, informes sobre camaradas, sign. 629-631. 
nuy Bardají y José Montorio González, todos ellos aragoneses, y tenía la misión de enlazar con Ángel Fuertes, Antonio, y establecer una base en la sierra de Alcubierre, en la provincia de Zaragoza. El 14 de septiembre llegaron a la sierra de Santo Domingo, donde esperaban encontrar a Antonio. Éste ya no estaba allí, pero se les agregaron otros tres hombres (Félix Lacuei, el Sos, de Sos del Rey Católico; Manuel Aznárez, de Luesia; y Mariano Navarro, el Tuerto de Fuencalderas) cuyas familias habían colaborado con los guerrilleros del grupo de Antonio mientras éste permaneció en la zona. Se les añadieron además un tal Antonio, que procedía del grupo guerrillero de José Cortés y probablemente se encontraba huido en la zona desde la época de las «invasiones», y Gabriel Cruz Navarro, el Madriles. ${ }^{183}$

Al parecer, por los datos aportados por Paloma Fernández Pancorbo, por documentos de la Dirección General de la Guardia Civil y por las fuentes orales, en octubre de 1945 el Tuerto de Fuencalderas y Félix Lacuei, el Sos, formaron su propio grupo guerrillero, compuesto por Manuel Nadal Sorrosal, el Chaval, Alejandro Fuentes Arilla, el Lobera, Gabriel Cruz Navarro el Madriles, y Baltasar Puente Pérez, el Sargento, y se instalaron en la sierra de Luna, en la zona limítrofe entre las provincias de Huesca y Zaragoza, donde contaban con una red de apoyos bastante importante. Por allí pasaban enlaces que entraban en España por el valle de Echo y enlazaban con Zaragoza a través de Zuera. Este grupo se mantuvo en funcionamiento hasta 1947, año en que, como veremos, cayó la mayor parte de la organización de esta zona y casi todos los guerrilleros. ${ }^{184}$

Finalmente, el grupo de Ibáñez logró dar con Antonio en Zaragoza a finales de 1945, donde éste trabajaba en la reorganización del PCE en la capital y la provincia. Allí coincidieron con José Ruiz Cuadrado, Ramón, que había sido enviado desde Francia por el PCE para hacerse cargo de la

183 Archivo del Comité Central del PCE, sección Movimiento Guerrillero, Equipo de pasos, informes sobre camaradas, sign. 693.

184 Doc. "Bandolerismo de la posguerra», s.f., Centro de Estudios Históricos de la Guardia Civil, Dirección General de la Guardia Civil. Paloma Fernández Pancorbo, «La guerrilla en Zaragoza y Huesca», en El movimiento guerrillero de los años cuarenta..., op. cit., p. 74. Conversación con Luis Ruiz Zaracaín. Madrid, 27 de mayo de 2000. Notas. 
organización comunista aragonesa, y consiguieron reunirse con obreros de las empresas aragonesas para crear "comités de resistencia», que permanecerían enlazados con la organización guerrillera. También lograron crear un "grupo de resistencia» entre los trabajadores de la estación del Arrabal. ${ }^{185}$ La misión de Ibáñez, una vez que hubiera ayudado a Antonio a organizar el PCE en Zaragoza, era ser responsable guerrillero del Comité Regional de Aragón, y para ello contaba con establecerse con su grupo en la sierra de Javalambre. Pero previamente, como no tenían dinero ni comida, acordaron establecer enlaces en Azuara, el pueblo de Ibáñez. De hecho, en esta localidad logró crearse una organización del PCE bastante extensa. Llegaron a su destino en la sierra turolense el 9 de enero de 1946 y se instalaron en unas cuevas que les indicó un pastor con el que contactaron gracias a León Quílez, que era natural de Camarena de la Sierra, denominadas cuevas del Regajo.

El grupo de guerrilleros no logró contactar con el PCE de Teruel, lo que no es sorprendente porque en la ciudad de Teruel no existía en aquel momento ninguna infraestructura comunista clandestina, a pesar de los temores del Gobierno Civil, que en diciembre de 1944 y coincidiendo con el inicio de la actividad guerrillera en la provincia envió un informe a Gobernación avisando acerca de un posible "complot comunista». ${ }^{186}$ En realidad, la represión sufrida en esta provincia había desmantelado completamente las organizaciones de izquierdas y no existía, como en Huesca, la proximidad de una frontera que permitiese la entrada y salida clandestina. Teruel se convirtió, desde la primavera de 1938 y más aún tras el final de la guerra, en un cul de sac, un callejón sin salida, y la única forma de escapar a la represión era la inmovilidad absoluta, el anonimato o el ocultamiento. No hay un estudio sobre el número de «topos» en esta provincia, pero suponemos que fueron numerosos. ${ }^{187}$

185 Paloma Fernández Pancorbo, "La guerrilla en Zaragoza y Huesca», en El movimiento guerrillero de los años cuarenta..., op. cit., p. 74.

186 AHPT, sección Gobierno Civil, caja 1130, carpeta 92.

187 Sobre los «topos», ver Jesús Torbado y Manuel Leguineche, Los topos. El testimonio estremecedor de quienes pasaron su vida escondidos en la España de posguerra. El País-Aguilar, Madrid, 1999 (1. a ed., 1977). Entre los testimonios que recogen, no hay ningún «topo» aragonés. Sin embargo, a través de documentos de la Dirección General de Seguridad y el Gobierno Civil de Teruel, tenemos noticia de dos "topos» turolenses. Uno es Bernabé Rovira, Garrobera, que desde el final de la guerra permaneció siete años escondido en el 
Lo que sí se detecta durante los últimos meses de 1944 y los primeros de 1945 es la presencia de grupos armados que atravesaban la provincia, dejaban en ocasiones octavillas de propaganda, se declaraban «maquis venidos de Francia» y solicitaban víveres o información sobre el emplazamiento de los cuarteles de la guardia civil. También en esos momentos comenzaron a producirse las primeras detenciones de "presuntos maquis», colaboradores, sospechosos o, simplemente, personas que no dieron cuenta de la presencia de guerrilleros, como los cinco detenidos (entre ellos, una mujer) que aparecen en una relación del 6 de diciembre de 1944. Esto significa que ya en fecha tan temprana había una predisposición por parte de un sector de la población local a apoyar a un movimiento de oposición a la dictadura; en el terreno de las actitudes, siempre difícil de analizar por otra parte, parece que existía una voluntad de resistencia que encontró en la presencia de los guerrilleros una forma efectiva de canalizarse y manifestarse. ${ }^{188}$

El primer encuentro violento documentado en la provincia turolense tuvo lugar el 2 de enero de 1945, cuando la guardia civil localizó a un grupo de diez guerrilleros en el término de La Cerollera. En el tiroteo murieron un guerrillero llamado Conejero y un peón caminero. ${ }^{189}$ En cuanto a los informes de las infiltraciones de presuntos grupos de maquis, su lectura en orden cronológico indica claramente que los grupos se desplazaban hacia el sureste de la provincia para concentrarse en las montañas del Maestrazgo y, en menor medida, los montes Universales. Sin embargo, a principios de 1945 la vigilancia se relajó, y el jefe provincial de

barrio de la Estrella de Mosqueruela "debido a su actuación anarquista», para posteriormente unirse a los guerrilleros. El otro es Joaquín Bosque Soriano, escondido en su domicilio desde 1947 por temor a las detenciones de enlaces de guerrilleros, con los cuales tenía relación, y detenido en su domicilio en 1953. AHPT, sección Gobierno Civil, caja 1031, carpeta 53 (Bernabé Rovira) y carpeta 37 (Joaquín Bosque).

188 En un documento de 6/12/44 aparece la siguiente relación de detenidos: Como «maqui» y conducido a Zaragoza, Segundo Collado Ruiz. Como presunto espía, Santos Benedicto Villanueva. Como sospechoso (conducido a Palencia), Santiago Froilán de Blanco. Por colaboración con "maquis», José Membrado Giner (Planas de Castellote). Por no denunciar la presencia de maquis, Tomás Ballester Planas, Manuel Bes Clavero, Vicente Félez Marqués, Modesto Mombiel y María Casabona Terzán. AHPT, sección Gobierno Civil, caja 1130, carpeta 98.

189 Memoria de la Comandancia de la Guardia Civil de Teruel (1966). Centro de Estudios Históricos de la Guardia Civil, Dirección General de la Guardia Civil. 
la Falange turolense podía afirmar que «la impresión general es que la masa de la población no se preocupa de los problemas de tipo político». 190 El 18 de enero se ordenó la desconcentración de las fuerzas enviadas a los pueblos de Aliaga, Allepuz, Fortanete, Rubielos de Mora y Villarluengo, donde existían sospechosos y huidos. Al no encontrarse indicios, las fuerzas regresaron a sus destinos. ${ }^{191}$

En febrero, la efervescencia política subió de tono: ese mes se produjo el atentado al local de Falange de Cuatro Caminos, en Madrid, que costó la vida a tres falangistas y que causó un fuerte impacto entre los simpatizantes del régimen. El mismo mes se celebró la Conferencia de Yalta, en la que se dirimía el futuro de la Europa posbélica. Ambos acontecimientos, internacional y nacional, confluyeron en el nivel local y produjeron una fuerte reacción defensiva en medios falangistas: en Teruel, el jefe provincial de Falange anunciaba que «se han recibido escritos y espontáneos ofrecimientos de falangistas y jefes locales en nombre de sus JONS manifestando están dispuestos a poner cada uno de su parte cuanto sea preciso para evitar todo aquello que sea contra la Falange o nuestro Caudillo». A ello se sumaba el temor por la presencia y actuación de los maquis. En los círculos falangistas, tras el hundimiento de Italia y Alemania, cundía el temor acerca de lo que podría suceder al acabar la guerra. ${ }^{192}$

Mientras tanto, Doroteo Ibáñez no lograba encontrar indicios de una organización clandestina en Teruel. Ante la ausencia de estructuras del PCE, Ibáñez volvió a Zaragoza a pedir instrucciones y Antonio le indicó que diese un "golpe económico" que le permitiese disponer de fondos para organizar el inexistente PCE turolense. Ibáñez también se llevó propaganda para repartir en los pueblos. Pero la climatología actuaba en contra de este plan: a causa de la nieve los guerrilleros no podían dar "golpes», y sólo lograron algún dinero en la localidad de Villastar. Con todo, según el informe enviado posteriormente por Ibáñez a la dirección, lograron organizar el PCE en Villel y Camarena de la Sierra. Lo cual puede querer decir, simplemente, que lograron establecer contacto con los conocidos de León

190 Jefatura Provincial de Teruel, informes mensuales. Enero de 1945. AGA, sección Presidencia, DNP, caja 183.

191 AHPT, sección Gobierno Civil, caja 1130, carpeta 99.

192 Jefatura Provincial de Teruel, informes mensuales, febrero de 1945. AGA, sección Presidencia, DNP, caja 183. 
Quílez, natural de Camarena, como se recordará, y pactar con ellos un servicio de enlaces o suministros, e incluso afiliar a alguno de ellos al partido, y explicarles brevemente en qué consistía el programa del PCE y la clase de lucha que pensaban llevar a cabo.

En todo caso, este pequeño núcleo no es el primer indicio de una estructura organizada de apoyo a la guerrilla en la provincia de Teruel. Previamente había una red de apoyos, probablemente muy inarticulada, vinculada a los guerrilleros instalados en Mosqueruela y Pitarque, de la que no sabemos apenas nada, y existía también una estructura de apoyo a los anarquistas de Aguaviva de los que hemos hablado al principio de este capítulo, y que en rigor forman el primer grupo clandestino armado turolense. La existencia de tales redes de apoyo confirma nuestra hipótesis acerca de la predisposición de ciertos sectores de la población rural, los calificados por las autoridades como «izquierdistas», a organizarse en rudimentarias estructuras de resistencia. Parece que la red de enlaces de este grupo anarquista estaba coordinada por el matrimonio formado por Saturnino Colomer y Felipa Pallarés, de Vistabella (Castellón); los dos eran militantes anarquistas y Felipa había sido dirigente de la FAI en Vistabella. En septiembre de 1945 se organizó otra partida armada, independientemente de la actuación de los guerrilleros comunistas: se trataba de la formada por Antonio Segura Ferrer, José M. ${ }^{a}$ Querol, Sedasé, y Victorino Prades Pitarch, Oronal, vecinos de Cinctorres (Castellón) que actuaban en la zona del Maestrazgo turolense, desde Mirambel hasta Aguaviva, y fueron responsables, entre otras acciones, de un atraco a los feriantes que regresaban de la feria de Cedrillas cometido en octubre de 1945. Dicho grupo tomó contacto en seguida con la guerrilla organizada por los comunistas a través de José Borrás, Cinctorrá, también natural de Cinctorres. Posteriormente, en 1948, la detención de uno de ellos, el Oronal, provocó una oleada de detenciones (46 detenciones en total, incluida la del Oronal, que murió por los disparos de la guardia civil durante su fuga de la cárcel de Morella) que supuso el desmoronamiento de la resistencia del Maestrazgo castellonense, lo que demuestra la amplitud e importancia de la red de apoyos que habían logrado tejer a su alrededor. ${ }^{193}$

193 Archivo del Comité Central del PCE, sección Movimiento Guerrillero, informe del camarada Ibáñez, jacquet 3-9. Archivo del Gobierno Civil de Castellón, caja 1 bis A, informes del 14 de junio de 1945 (anarquistas) y del 25 de abril, 22 de mayo y 17 de noviembre de 1948 (grupo de Cinctorres). 
Antes de continuar con el relato de la formación de los primeros núcleos guerilleros aragoneses, queremos hacer notar que la intención inicial de los dirigentes comunistas no era establecer una guerrilla rural, sino crear grupos armados con bases en la sierra que apoyaran la reorganización del partido en las poblaciones, principalmente en las capitales de provincia, objetivo que sólo se logró en Zaragoza. En la provincia de Huesca, fue sobre todo en Monzón y Barbastro donde, como veremos, se establecieron células comunistas en contacto con el grupo armado. Y en Teruel la guerrilla se convirtió en un fenómeno con un carácter marcadamente rural y adoptó unas características diferenciadas de las del resto de la región. Pero ello no se debió a una táctica determinada de antemano, sino a que la sociedad rural turolense presentaba las características adecuadas para que fructificase un movimiento de este tipo. La dirección «francesa» del PCE no pretendía, pues, en un principio, crear una guerrilla campesina sino un movimiento de resistencia con ramificaciones tanto urbanas como rurales, y ello es fácilmente deducible de las instrucciones que recibieron los guerrilleros enviados al interior en estos primeros momentos, como Doroteo Ibáñez y su grupo. Pero las circunstancias interiores modificaron de forma esencial esta táctica, y la guerrilla comunista hubo de adaptarse al sustrato social que encontró en el interior. De hecho, los mandos comunistas «franceses» se quejaban del escaso «trabajo político» llevado a cabo por los guerrilleros, y de que utilizaran los contactos con la gente de los pueblos para montar estructuras de apoyo y suministro, en lugar de extender la organización del partido. Lo cual revela, por su parte, un grave desconocimiento de la situación interna española y de la de los propios guerrilleros, para quienes poner en pie dichas redes constituía una garantía de supervivencia.

El grupo anarquista al que nos referimos estaba formado por José Ramiá Ciprés, el Petrol, y Fernando Castel Bernuz, el Rabós, que se fugaron de la prisión de Mas de las Matas en febrero de 1940. A ellos se unieron otros individuos, lo que dio lugar a una partida armada que actuó en una amplia zona que no se limita a los alrededores de Aguaviva, sino que abarca un área que comprende la zona de Santolea, la de Mosqueruela, Aliaga e incluso parte de Castellón (Villorres y el Forcall). Tenían numerosos puntos de apoyo en masías de esta zona; cuando una operación policial desarticule su red de colaboradores, se efectuarán 16 detenciones. El 6 de mayo de 1946, el Rabós morirá a manos de la guardia civil; en cuanto al Petrol, será liquidado por los guerrilleros comunistas en diciembre de 1946, hecho del que trataremos más ampliamente. Ver Mercedes Yusta, La guerra de los vencidos..., op. cit., pp. 100-104. 
En lo que respecta a la situación interna, realmente el PCE estaba poco extendido; en sus informes, Ibáñez aludía a la influencia de la CNT en la provincia de Teruel, influencia que podríamos hacer extensiva al resto de Aragón y sobre todo a Huesca, provincia de gran tradición anarquista. La escasa extensión del comunismo y el desconocimiento general de su práctica política se pone de manifiesto cuando se alude a que «la gente atrasada [...] cuando les hablan de comunismo se forman una terrible confusión. Estas gentes creen que el comunismo es el "comunismo libertario" que se extendió por allí cuando nuestra guerra. Un ejemplo: hay gente que dicen que son amigos de Líster y de Galán, por su conducta en la guerra, pero sobre el comunismo tienen recelos. Es un problema de confusión más que de otra cosa y, sobre todo, de falta de esclarecimiento mediante un buen trabajo político». Efectivamente, en este informe queda de manifiesto la enorme confusión de un sector de la población, que mezclaba a Galán (fusilado en 1930) con Líster y el comunismo con el anarquismo. Tanto Ibáñez como otros guerrilleros o enlaces aludían también a la escasa utilidad de realizar un trabajo de propaganda teórica entre los campesinos, muchos de ellos analfabetos, y en todo caso ajenos, en general, a la cultura de lo escrito. Ibáñez puntualizaba: «Las hojas o periódicos del partido eran más bien para entregárselas a los camaradas de los pueblos que a toda la gente». Se trata, como vemos, de un choque cultural entre una tradición política basada en la reflexión y el análisis teórico marxista y una cultura de la acción, vinculada, muy posiblemente, a la extensión del sindicalismo cenetista, pero sobre todo a una cultura campesina muy poco dada al pensamiento abstracto, centrada en prácticas concretas que proporcionan un resultado palpable, real e inmediato. La táctica propagandística de los mandos comunistas del exilio, a pesar de sus llamadas grandilocuentes al campesinado, estaba pensada para un medio urbano. ${ }^{194}$

Mientras tanto, el PCE seguía enviando grupos de hombres al interior de Aragón. En una fecha sin determinar se formó el Grupo de Guerrilleros II de Aragón, compuesto de cinco hombres, todos ellos naturales de la provincia de Huesca, excepto uno nacido en Alcañiz y cuya suerte desconocemos. Ni siquiera sabemos si llegaron a entrar en España; en todo caso, ninguno formó posteriormente parte de la Agrupación Guerrillera del Alto

194 Informe del camarada Ibáñez, jacquet 3-9, Archivo del Comité Central del PCE, sección Movimiento Guerrillero. 
Aragón ni de otra organización guerrillera. Un grupo distinto, compuesto por ocho individuos, fue localizado por un retén formado por paisanos y guardias civiles cerca de Salinas de Hoz el 19 de enero de 1946; de los ocho, tres fueron muertos, uno resultó herido y cuatro fueron hechos prisioneros. Éstos declararon que se había disuelto la Unión de Guerrilleros Españoles en el interior de Francia para la reconquista de España y que sus miembros habían sido licenciados, pasando a formar parte de una nueva organización general de guerrilleros con base en Toulouse a las órdenes de «un tal general Luis» (se trata de Luis Fernández, antiguo jefe de la guerrilla de la UNE). Los prisioneros eran también portadores de propaganda destinada a la guardia civil, el ejército y los campesinos en la que se propugnaba la unión a los guerrilleros como vanguardia de la insurrección nacional. Las autoridades señalaron que «la infiltración parece tener carácter general», lo cual confirmaba el temor de los medios oficiales a una nueva ofensiva guerrillera una vez finalizada la segunda guerra mundial. ${ }^{195}$

En febrero de 1946 se produjo una ola de detenciones en Zaragoza, provocada por la detención y confesiones de un tal Atienza, que había ido con un grupo guerrillero a la sierra de Santo Domingo. Pero Antonio no fue detenido ya que se hallaba en Valencia, adonde se había trasladado por orden del partido para organizar la región levantina. Tras las detenciones, Antonio volvió a Zaragoza a cambiar de sitio la emisora, que no había sido descubierta, y se reintegró a la zona de Levante, donde había comenzado a organizar los diversos grupos dispersos de guerrilleros que «entonces vegetaban» por aquella zona. Se trataba de los grupos de Delicado, Cinctorrá y otros de las mismas características, de los cuales ya hemos hablado. Según Ibáñez, hasta el momento de tomar contacto con Antonio se dedicaban únicamente a subsistir. Es decir, no realizaban una actividad propiamente guerrillera (sabotajes, actos de propaganda...). Ibáńez aseguraba que «esta falta de actividad de los grupos era debida a la falta de orientación del Partido», es decir, al desconocimiento de la táctica guerrillera que estaba siendo definida y aplicada para adaptarse a las condiciones de la lucha en el interior de España, diferente en muchos sentidos a la llevada a cabo en la Resistencia francesa. Además — continúa Ibáñez-, la mayoría de aquellos hombres no habían recibido cursos en escuelas guerrilleras,

195 Archivo del Gobierno Civil de Zaragoza, sección Asuntos Gubernativos, caja 103, carpeta 5. 
desconocían el manejo de explosivos, etc., y tampoco habían tenido una participación guerrillera en Francia en la clandestinidad. Estos guerrilleros, aislados e inexpertos, habían sufrido numerosas bajas por imprudencia y por «fiarse de la gente»: cuando iban a pedir comida a las casas, la reacción de los campesinos era, frecuentemente, avisar a la guardia civil. «Pero en seguida han aceptado el mando único y han acatado las órdenes del Partido», sigue diciendo Ibáñez.

En realidad, se produjo un choque entre los hombres que se habían establecido en la zona desde finales de 1944 y los recién llegados, con instrucciones precisas para organizar dichos grupos y también para dirigirlos. Probablemente, la tarea de Ibáñez y Antonio en ese momento tuvo mucho de labor diplomática. La clave estaba en ganarse a los jefes de grupo, de los cuales no es cierto que, como dice Ibáñez, fuesen todos comunistas: Cinctorrá era anarquista, y no sabemos nada del pasado de Delicado, salvo que participó en la Resistencia francesa y que alcanzó el grado de comandante en las FFI. Parece que sí era comunista, por los informes que da de él el guerrillero Carlos, Jesús Caellas Aymerich, que se les había sumado procedente de Lérida (y de las Juventudes Libertarias). Pero los jefes de grupo, fuesen cuales fuesen sus militancias en el pasado, aceptaron la integración en una estructura que sería genuinamente comunista. Después de todo, el PCE era el único partido que apoyaba explícitamente la lucha armada. La integración les ofreció puestos de responsabilidad en la nueva estructura guerrillera y dio un sentido a su permanencia en el monte; significaba la oportunidad de reincorporarse a la lucha, en suma. En palabras de Ibáñez, estos hombres «no se habían corrompido ni convertido en grupos de bandoleros» (a pesar de que su única actividad era la subsistencia, es decir, la obtención de dinero y víveres mediante atracos, robos o pidiendo en las masías), y pusieron el dinero obtenido en los atracos al servicio del partido y de la creación de la organización guerillera.

La financiación para la creación de la AGLA no provino, sin embargo, de fondos del PCE ni de los aportados por los guerrilleros, sino de una operación que en su día tuvo una enorme resonancia: el asalto al tren pagador de los ferroviarios, que se llevó a cabo el 7 de julio de 1946 en el apeadero de Caudé. Para preparar el golpe, Antonio contaba con tres enlaces de la CNT que le proporcionaban información, y además con los guerrilleros 
Pepito, Grande, Vargas, Nelson y Manso, todos ellos comunistas. Los dos primeros, de los que hablaremos más adelante, no se encontraban entonces en el monte, sino que ejercían su actividad principalmente en la ciudad de Valencia, donde habían organizado un "grupo de acción", aunque, como se ve, su contacto con la estructura guerrillera era muy estrecho. El 7 de julio, pues, se produjo el asalto al tren del Central-Aragón en Caudé, en el que se obtuvieron 750000 pts., que financiaron el inicio de la AGLA, y seguidamente los enlaces de la CNT «se incorporan a las guerrillas y más tarde hubo que mandarles a Valencia con documentación pues no hacían más que enredar». También el guerrillero Carlos hace alusión a que había un problema delicado con los miembros de la CNT que habían informado para el golpe, y que se encontraban en las guerrillas simplemente en calidad de refugiados. Una vez más, la tensión entre ambas organizaciones se manifestaba en el seno de la guerrilla. ${ }^{196}$

En agosto de 1946, el proceso de coordinación de los diferentes grupos se había completado; los jefes de grupo más importantes se reunieron en la cueva de Camarena de la Sierra en la que Ibáñez había establecido su base, y de esa reunión surgió la Agrupación Guerrillera de Levante y Aragón, que agrupaba territorios y grupos guerrilleros de las provincias de Teruel, Cuenca, Valencia, Castellón, Guadalajara y Tarragona. El jefe de la AGLA, sin embargo, no sería Antonio, el artífice de su creación, sino Vicente Galarza, Andrés, natural de Buñol (Valencia), designado por el partido para ocupar este puesto y enviado desde Francia vía Madrid. Se trataba de un antiguo comandante de las FFI, de gran prestigio militar y político. Ibáñez hace alusión a que estaba muy relacionado con Santiago Carrillo y Modesto. Pero su experiencia acerca del funcionamiento de la guerrilla en el interior era muy escasa, y carecía de un contacto previo con la realidad social de la zona o con los guerrilleros que actuaban en ella. De hecho, instaló su puesto de mando en la ciudad de Valencia, en un piso en el que recibía a los enlaces de los diferentes sectores.

La creación de la AGLA significa, realmente, la unión desde el punto de vista organizativo de dos grupos diferentes de guerrilleros: los que actuaban en la zona de Levante, y que dependían del Comité Provincial

196 Informe del camarada Ibáñez, jacquet 3-9, informe de Carlos sobre la AGLA desde octubre de 1944, Archivo del Comité Central del PCE, sección Movimiento Guerrillero, Equipo de pasos, informes sobre camaradas, sign. 629-631. 
del PCE de Valencia, y los que tenían como territorio la provincia de Teruel, es decir, los guerrilleros relacionados con Ibáñez y su grupo, a los que los levantinos conocían genéricamente como «los maños». Al poner al mando de la Agrupacion a Andrés, que además estableció su base en la ciudad de Valencia, se concedió preeminencia al sector levantino frente al aragonés y se privilegió la relación de los guerrilleros de Teruel con los de la zona de Levante, antes que con otros grupos que actuaban en el resto de Aragón y con los cuales no se llegó a establecer contacto. La zona guerrillera se dividió en cuatro sectores denominados $11 .^{\circ}, 5^{\circ}, 17 .^{\circ}$ y $23 .^{\circ}$ (este último se añadió en noviembre de 1947), y al frente de cada uno de ellos se colocó a un jefe de sector.

El 11. ${ }^{\circ}$ sector ocupaba una franja de la sierra de Albarracín (hasta Mora de Rubielos), en Teruel; desde el límite de Teruel hasta Segorbe, en la de Castellón; desde el límite de Teruel hasta Liria, Chiva y Requena, en Valencia; en Cuenca, desde Teruel hasta Cañete y desde Valencia hasta Motilla del Palancar. El 5..$^{\circ}$ sector ocupaba la franja oeste de la provincia de Teruel hasta Monreal del Campo y una pequeña porción de Cuenca situada al norte de la capital, y durante algunos períodos funcionó como parte del $11 .^{\circ}$. En cuanto al $17 .^{\circ}$ sector, ocupaba los partidos judiciales de Aliaga, Montalbán, Valderrobres y Alcañiz, en Teruel, y desde Morella hasta el mar, en Castellón. Posteriormente, el norte de este sector se desgajó para formar el sector 23. ${ }^{\circ} .^{197}$

Al frente del $11 .^{\circ}$ sector, que abarcaba principalmente territorio de las provincias de Valencia y Castellón de la Plana (es decir, territorio levantino), se encontraba el guerrillero Florián García, Grande, que se incorporó al monte desde la ciudad de Valencia, donde formaba parte del Comité Provincial como secretario de propaganda. Grande tenía una larga trayectoria de militancia comunista; natural de Aldealcorvo (Segovia), llegó a Madrid en 1931 y con catorce años empezó a trabajar de camarero. Allí tomó contacto con la Confederación General de Trabajadores Unidos (CGTU), sector de Hostelería, y también se relacionó por primera vez con militantes del PCE. Tras una breve estancia en la cárcel por participar en una huelga, al salir en diciembre de 1933 ingresó en las Juventudes Comu-

197 Una información detallada acerca de la organización de la AGLA, en Fernanda Romeu, Más allá..., op. cit. Para la distribución del territorio por sectores, ib., pp. 97-98. 
nistas. Al producirse la fusión de la CGTU con la UGT, Grande pasó al sindicato de Comercio. Durante la guerra se comprometió por entero con el aparato comunista, y en el curso de la guerra interna que dividió al campo republicano en la primavera de 1937 participó en la detención de miembros del POUM y de la FAI en Castellón de la Plana. Al final de la guerra fue a parar a Alicante (donde coincidió con otros futuros guerrilleros, como Vilches, Corredor y otros) y allí cayó prisionero. Estuvo en Albatera, desde donde fue trasladado a Portacoeli y a una cárcel de Alcira. Salió en libertad provisional en agosto de 1940.

A mediados de 1941 Grande se trasladó a Madrid, donde un miembro del PCE se puso en contacto con él y le encargó organizar a los oficiales del futuro ejército guerrillero en unidades. Pero perdió este contacto debido a una ola de detenciones. Retomó el contacto a través de Francisco Corredor, con el cual tenía una relación personal y que, posteriormente, sería una figura muy importante de la AGLA. Grande se trasladó a Valencia, donde pasó a formar parte del Comité Provincial y organizó dieciséis comarcales. A finales del año 1946, yendo con Corredor, fueron detenidos por dos guardias civiles; Corredor mató a uno de un disparo y ambos decidieron esconderse y seguidamente subir al monte, donde ocuparían puestos de responsabilidad en la guerrilla. De hecho, Grande pasó casi inmediatamente a ocuparse del $11 .^{\circ}$ sector y no abandonaría este puesto hasta 1952, momento en que, con sus hombres, atravesó la frontera para exiliarse en Francia. Fueron los últimos guerrilleros de la AGLA en abandonar la zona. ${ }^{198}$

Francisco Corredor Serrano, Pepito el Gafas, también fue un personaje clave de la AGLA. Complejo y controvertido, ocupó puestos de gran responsabilidad, como lugarteniente de Antonio, responsable de la escuela guerrillera que se creó en el término de Aguaviva (Teruel) y miembro del Estado Mayor de la Agrupación, del que fue el máximo responsable a partir del verano de 1947. Pepito, de origen vasco, procedente de una familia de la burguesía y estudiante de ingeniería, ingresó en la FUE antes de terminar el bachillerato. Durante la guerra tuvo actividad política, ingresó en un grupo de las Milicias Antifascistas de Obreros y Campesinos (MAOC)

198 Autobiografía de Grande, Archivo del Comité Central del PCE, sección Movimiento Guerrillero, Equipo de pasos, informes sobre camaradas, sign. 624-625. 
y luego en un batallón de la Federación Española de Trabajadores de la Enseñanza (FETE), para posteriormente entrar a formar parte del Servicio de Inspección Especial Periférico (SIEP) y del Estado Mayor de la IX División. Al igual que Grande, se vio envuelto en los acontecimientos que marcaron el año 1937; tuvo que participar como juez en un juicio contra oficiales de la CNT acusados de asesinar a varios oficiales comunistas, uno de los cuales era compañero de estudios de Pepito. Éste fue acusado por los oficiales de la CNT de haberlos interrogado violentamente y se vio obligado a abandonar el puesto. Tras la guerra estuvo en Albatera, donde no tuvo noticias de la existencia de ninguna célula del PCE. Luego fue trasladado a Portacoeli, donde se encontró con Grande. Ya en Valencia, Pepito contactó con el PCE; junto con Grande y otros individuos formó grupos de acción que se dedicaban a realizar atracos a bancos y sabotajes. Estaban en contacto con la recién formada AGLA cuando sucedió el incidente en el curso del cual Pepito dio muerte a un guardia civil, lo que les obligó a él y a Grande a reunirse con los guerrilleros en el monte.

Ambos, Pepito y Grande, son ejemplos característicos de un tipo de guerrillero fuertemente politizado, con una experiencia previa de guerrilla urbana y, anteriormente, una importante implicación en el aparato militar comunista durante la guerra, que les llevó a participar en la represión llevada a cabo por el PCE contra el POUM y anarquistas durante el año 37. En este sentido, se diferencian tanto de los guerrilleros venidos de Francia, con su experiencia de participación en la Resistencia contra los nazis, como de los guerrilleros que se fueron incorporando a la guerrilla desde sus lugares de origen, sin una experiencia previa de militancia. Ésta es la razón de que nos hayamos detenido brevemente en analizar sus biografías, trazadas por ellos mismos a instancias del aparato del PCE y completadas con informes de algunos de sus compañeros, bastante homogéneos en lo que respecta a Grande (un hombre respetado como compañero y jefe firme y ecuánime), más conflictivos en el caso de Pepito, hombre con un carácter fuerte y unos hábitos intelectuales calificados de "pequeñoburgueses», que se ganó el respeto pero no la confianza de los guerrilleros.

En cuanto al territorio aragonés que estaba bajo la influencia de la recién creada AGLA, Doroteo Ibáñez consiguió finalmente en junio de 1946 enlazar con el Comité Provincial de Teruel a través de la organización del pueblo de Manzanera. Al parecer, el Comité turolense tenía con- 
tacto con Zaragoza. El enlace de Ibáñez era un tal Amorós, que le puso en relación con la organización del partido en los pueblos de Aguaviva y Mosqueruela, localidades en cuyas inmediaciones se instalaron dos importantes campamentos guerrilleros. La organización de Aguaviva, según sabemos por fuentes orales, fue obra de José Mir, el Cona, antiguo miembro del SIEP durante la guerra civil. En cuanto a Mosqueruela, el contacto con la población ya había sido iniciado por el grupo de Delicado desde 1944. Un año después, en octubre de 1945, la dueña de la masía Las Salegas, cerca de Mosqueruela, fue detenida por ocultar hombres armados. En sus declaraciones, confesó que sus hijos José y Alberto Vicente Zafón (que se habían unido a Delicado, como se recordará) mantenían conversaciones con los guerrilleros. De José Vicente Zafón, Pepito, sabemos que había pertenecido a la CNT y al comité revolucionario de Mosqueruela; tras la guerra, pasó por un campo de concentración y posteriormente volvió a casa. Los hermanos Vicente Zafón había partido al monte dejando una carta firmada por Jesús Arcede, que en realidad era Jesús Caellas Aymerich, Carlos, jefe guerrillero, dirigida a Juan Arcede, en Caldes de Montbuy (Barcelona). Por tanto, en Mosqueruela había en 1945 un conato de organización conectada con Barcelona a través de los hermanos Vicente, los cuales, a su vez, tenían contacto con la guerrilla a través del grupo del guerrillero Carlos (de procedencia libertaria, como ellos). En el mes de marzo de 1946 hubo una redada en estos pueblos, y al parecer la organización quedó bastante maltrecha. ${ }^{199}$

Por lo tanto, a pesar de los informes de Ibáñez acerca de la pasividad de los grupos de guerrilleros existentes en la provincia turolense antes del contacto con Antonio, lo cierto es que previamente a la configuración de la AGLA ya había una importante actividad guerrillera en la provincia, al menos lo bastante importante para inquietar a las autoridades. No sólo se producían atracos (cuyo carácter político siempre se puede poner en duda), sino que comenzaron a sucederse los actos de propaganda y se produjeron los primeros asesinatos que podemos calificar de "políticos», aunque esta cuestión es compleja, pues los grupos que actuaban entonces estaban compuestos en muchos casos por individuos naturales de la zona,

199 Informe del camarada Ibáñez. Archivo del Comité Central del PCE, sección Movimiento Guerrillero, jacquet 3-9. Entrevista, Joaquín Buñuel Mir. Aguaviva, 6 de agosto de 1996. AHPT, sección Gobierno Civil, caja 1130, carpeta 129. 
y en estas muertes se mezclan componentes políticos y venganzas personales; las redes que unen a los pobladores de un determinado núcleo son muy complejas, y las afinidades o diferencias políticas interaccionan con otras de tipo económico o personal.

En agosto de 1945 se produjo el asesinato de Balbina Puerto García, esposa del alcalde franquista de Cañada de Benatanduz, que reúne las características arriba señaladas: el cuerpo fue encontrado sin señales de robo o violación, por lo que quedaron descartados estos dos móviles, y las autoridades llegaron a la conclusión de que conocía a su agresor. Se supuso que se trataba de un grupo de cinco individuos armados que fueron vistos en las inmediaciones aquella noche, antes de que se produjese la muerte. Según algunos testimonios, Balbina Puerto, al parecer, se ensañaba con los prisioneros republicanos y gozaba de una pésima fama entre sus convecinos izquierdistas, además de mantener conflictos con sus vecinos a causa del agua de riego.

El 25 de noviembre de 1945 era asesinado Manuel García Monforte, teniente de alcalde y jefe local de Falange en Dos Torres de Mercader, por dos individuos que lo sacaron de su casa y lo mataron a la salida del pueblo. Uno de ellos fue identificado como Isidro Irance, vecino de Dos Torres, uno de cuyos hijos acababa de ser detenido como enlace de los guerrilleros. En esta muerte también parece haber un motivo personal. ${ }^{200}$

Antes de la unificación comunista se produjeron actos de propaganda por parte de estas partidas compuestas, en gran medida, por naturales de la zona. Por ejemplo, en julio de 1945 se encontraron en Utrillas numerosas octavillas esparcidas por el suelo, en las que podía leerse: «Atención mineros de Utrillas. España se encuentra en poder de los criminales, muy pronto morirán. Viva Estalin. Los Maquis.» Y también: «Atención mineros de Utrillas. España se encuentra en poder de los criminales. Muy pronto morirán. Muera Franco y la Falange viva Negrín y los Maquis». El vocabulario utilizado por los autores de estas octavillas difiere mucho del que emplearían posteriormente los guerrilleros de la AGLA, que jamás se autocalificaron de maquis (término empleado por la población y, en menor medida, por las autoridades y fuerzas represivas, que preferían hablar de «bandoleros»). ${ }^{201}$

200 AHPT, sección Gobierno Civil, caja 1130, carpetas 133 y 136.

201 AHPT, sección Gobierno Civil, caja 1130, carpeta 142. 
La mayoría de estos grupos se integraron en la estructura comunista, es decir, en la AGLA, pero sus actuaciones siguieron revistiendo un carácter muy semejante al que hemos analizado. Después de todo, los guerrilleros llegados desde Francia eran cada vez menos (en 1947 quedan unos veinte en todo el territorio de la Agrupación) y era inevitable que, más allá de las directrices del PCE (que tampoco eran demasiado explícitas respecto a las acciones concretas a efectuar), estos grupos ejercieran una especie de «justicia popular», dirigiendo sus ataques a las personas concretas, con nombre y apellidos, que encarnaban para ellos al régimen franquista. $Y$ en realidad, todo indica que los jefes guerilleros, concretamente Antonio, buen conocedor de la realidad social del campo aragonés, apoyaban (o al menos consentían) estas acciones.

A partir de la constitución de la AGLA, las acciones comenzaron a revestir un carácter más «organizado». Una buena red de informadores les permitió dar el 16 de mayo de 1946 un "golpe» bastante efectivo: el atraco al recaudador de la contribución en la carretera de Morella, en el término de Nogueruelas. Se apoderaron al parecer de 174000 pts. (en otro lugar se habla de 154000 ), fruto de la recaudación y del dinero que llevaban encima el recaudador y sus acompañantes (la esposa del recaudador, su hija, su auxiliar y otro individuo). Los guerrilleros les entregaron un papel escrito a máquina en el que se leía: «Todo delator consciente o inconsciente de los guerrilleros será ajusticiado por los mismos inmediatamente. Agrupación guerrillera». Y los testigos dijeron que se comunicaban entre ellos en francés. Son elementos que componen una buena muestra del nuevo modus operandi de la guerrilla turolense. ${ }^{202}$

Otro ejemplo de la mejora en la organización y del aumento de recursos de los guerrilleros es el asalto al tren en la estación de Caparrates, efectuado en agosto de 1946, en el que un grupo de hombres armados asaltaron el tren 6003, encerraron al personal de la estación y posteriormente hicieron salir el tren de las vías colocando una bomba en la máquina. Según el informe policial, «los asaltantes eran todos jóvenes y llevaban cazadoras como las usadas en el Ejército». En la fachada del edificio dejaron una inscripción con tinta roja en la que se daban vivas a la República, al Gobierno Giral y a los guerrilleros, pintada que fue rápidamente borrada para evi-

202 AHPT, sección Gobierno Civil, caja 1031, carpeta 48. 
tar que fuese advertida por los transeúntes. También dejaron una hoja escrita con multicopista y varias tiras de papel dirigidas a los miembros de la guardia civil y del Somatén en las que se amenazaba de muerte (o, según la nota, con el "ajusticiamiento») a todo individuo de ambas instituciones que se destacase en la lucha con los guerrilleros. Las notas finalizaban con vivas a la República, mueras a Franco y estaban firmadas, posiblemente por primera vez, por la «Agrupación Guerrillera de Levante», desconocida hasta el momento por las fuerzas represivas. ${ }^{203}$ Pero en ese mes de agosto la Agrupación iba a dar otra muestra de su fuerza y organización en Teruel con el asalto simultáneo a las centrales eléctricas El Maestrazgo y la Fonseca, en el término de Ladruñán. Las autoridades reconocían que "se desconocen los componentes de estas partidas", pero deducían que "pudiera tratarse de los llamados "Guerrilleros de Levante", los cuales unos son procedentes de Francia, otros huidos y algunos libertos condicionales de los pueblos que huyen para evitar la acción de la justicia, cuya partida tiene su albergue en los límites de las provincias de Castellón, Valencia, Cuenca y Teruel». Acertadamente, las autoridades detectaron desde el primer momento tanto la composición heterogénea de los miembros de la Agrupación como su emplazamiento geográfico interprovincial. ${ }^{204}$

En el proceso de consolidación de la Agrupación Guerrillera de Levante y Aragón tuvo también un papel destacado la edición de un periódico, El Guerrillero, que servía a la vez como órgano de expresión y como medio de propaganda de los guerrilleros comunistas. El responsable de la edición era el guerrillero Luciano Mamilo Muñoz, Deseado, que había entrado en España en el grupo de Ibáñez en 1945. El primer número data de noviembre de 1946, y en él los guerrilleros hacían una «declaración de principios» en la cual saludaban a todos los antifranquistas («obreros, campesinos, intelectuales, militares y patriotas en general»), declaraban los motivos de su lucha, su «adhesión inquebrantable al gobierno Giral» (y, por tanto, su condición de defensores de la Segunda República y de la Constitución de 1931) e invitaban a los antifranquistas a unirse "cada uno a su manera» a su lucha "contra el terror, por la abolición de las leyes franquistas, por la libertad de los presos políticos, por la libertad de prensa y

203 AHPT, sección Gobierno Civil, caja 1031, carpeta 54.

204 AHPT, sección Gobierno Civil, caja 1031, carpeta 56. 
palabra, por elecciones libres, por la restauración de la República». El número, ciclostilado, se completaba con un parte de operaciones, diversas consignas (como «los guerrilleros son los únicos en España que gozan de verdadera libertad») y artículos referentes a su posición respecto a las fuerzas de la guardia civil, sus enemigos directos, y el campesinado, su aliado natural. La estructura cambiará poco durante toda la vida de la publicación (cuyo último número apareció en mayo de 1949), exceptuando la presencia cada vez más importante de artículos dirigidos al campesinado y relacionados con las problemáticas locales más acuciantes, sobre todo las relacionadas con la Fiscalía de Tasas y Abastos: los guerrilleros llamaban frecuentemente a los campesinos a reaccionar contra la represión económica del régimen e incitaban a la «insumisión fiscal».

Sin embargo, no todo en el proceso de unificación y consolidación que estamos describiendo transcurrió de forma pacífica, y se produjeron episodios en el interior de la organización guerrillera que permanecen envueltos en la oscuridad. No todos aceptaron sin más la supremacía comunista y sus directrices en la lucha guerrillera; y por parte de los comunistas, en un momento de consolidación de la estructura guerrillera, de represión y clandestinidad y, por añadidura, de fuerte influencia estalinista impuesta por la dirección vía Moscú-Toulouse, no había sitio para ninguna desviación anarquizante. Hubo, por lo tanto, grupos e individuos que no aceptaron las condiciones impuestas por los guerrilleros comunistas y que fueron eliminados. El informe de Ibáñez describe tres casos en la zona de Teruel-Levante, alguno de los cuales conocemos también por otras fuentes.

El caso más llamativo es el del guerrillero Delicado, uno de los pioneros en establecerse en la zona. Delicado era muy conocido en Francia, donde llegó a ser comandante durante la Liberación. Después de instalarse en la zona de Mosqueruela y Pitarque, y posteriormente trasladarse a Aguaviva para pasar el invierno, entró en contacto con Antonio y con el grupo de Doroteo Ibáñez. Antes de la constitución de la AGLA, Delicado fue enviado a Valencia a contactar con el partido, cosa que no consiguió, pero en cambio enlazó con miembros de la CNT en febrero de 1946, «a los que facilitó medios para llegar a la Base de ellos», según Ibáñez, comentario que es nuestra única pista acerca de una base de guerrilleros anarquistas en la zona de Levante. Delicado organizó el viaje de un responsable de la CNT, pero ambos fueron detenidos; según Ibáñez, Delicado traicionó y pasó a ser 
confidente de la policía. Antonio ordenó ajusticiarlo, lo que se realizó el 17 de noviembre de 1946. Otro guerrillero que informó sobre Delicado, Jesús Caellas Aymerich, Carlos, posterior responsable del 23. ${ }^{\circ}$ sector, no aludía a estas detenciones, sino que relataba que Delicado subió al monte con el jefe del regional de la CNT y el redactor jefe de Fragua Social, añadiendo que su trabajo en Valencia no fue "nada satisfactorio». ${ }^{205}$ Quizá la verdadera razón de su muerte estriba en esos contactos con la CNT, que debieron de parecer muy sospechosos a los ojos de los mandos comunistas. También es digno de ser resaltado el hecho de que este guerrillero agrupó en torno a sí a buen número de militantes o exmilitantes anarquistas. La hipótesis, en todo caso, queda abierta.

En el caso del siguiente ajusticiado del que habla Ibáñez, la motivación está bastante más clara. Se trata del aludido Petrol (al que Ibáñez llama Petrov), el huido anarquista que escapó del depósito de Mas de las Matas junto a su convecino el Rabós, y que formó el primer grupo armado de la provincia. Posteriormente, el Petrol se unió a un grupo de guerrilleros de la AGLA, y se le dio muerte por su tendencia anarquista, que no abandonó al insertarse en la guerrilla comunista. Al parecer, cuando se trató de imponerle la disciplina y el control del partido se escapó con otro guerrillero. Tras salir en su busca, se ajustició al Petrol, y el otro escapó. Más tarde se localizó a este último en otro grupo guerrillero, pero no se tomaron medidas contra él, ya que "parece ser que no se porta[ba] mal». La muerte del Petrol se produjo el 24 de diciembre de 1946, y fue anunciada en el tercer número del periódico de la AGLA, El Guerrillero. Al parecer, uno de los reproches que se le hacían al Petrol era que robaba, pero sus golpes diferían de los «golpes económicos» de los guerrilleros porque no eran presentados bajo la envoltura de una acción política. Por tanto, sus acciones desprestigiaban a la guerrilla ante la población. Ya hemos analizado en otro trabajo la figura del Petrol y no vamos a insistir en ello. En cualquier caso, su forma de actuación no se ajustaba a la ortodoxia guerrillera, y eso era algo que no se podía permitir en un momento de consolidación de la organización comunista. Pero lo más llamativo es que el grupo de la AGLA al que se

205 Informe de Carlos sobre la AGLA desde octubre de 1944, Archivo del Comité Central del PCE, sección Movimiento Guerrillero, Equipo de pasos, informes sobre camaradas, sign. 629-631. 
incorporó el Petrol era, precisamente, el grupo de Delicado, si hacemos caso de Tomás Cossías, antiguo miembro de la Brigada Político-Social destacado en la zona de Levante para la lucha antiguerrillera. ${ }^{206}$

El último caso es el de Valentín, un asturiano, antiguo carabinero llegado de Francia. Intentaba reunir un grupo de guerrilleros para volver a Francia; el 1 de noviembre de 1946 Ibáñez lo asesinó. En esta ocasión, fue una forma expeditiva de solventar un caso de desmoralización que podría haber generado una escisión en el movimiento guerrillero y una deserción en masa, lo que se evitó eliminando físicamente al responsable.

De este modo, a finales de 1946 la AGLA disponía ya de una estructura organizativa consolidada, con tres sectores que incluían un amplio territorio de actuación, con fondos para financiar el comienzo de la andadura de la guerrilla y con una red de apoyos y colaboradores que contaba con el respaldo de las regionales comunistas de Aragón y Valencia, pero también de numerosos campesinos y campesinas relacionados con guerrilleros naturales de la zona o, simplemente, simpatizantes de éstos. Y mientras tanto, de forma absolutamente autónoma e independiente del proceso llevado a cabo en el sur de Aragón, en el norte se estaba configurando otra organización guerrillera, también de naturaleza comunista, y también por iniciativa de los mandos comunistas que operaban desde el exilio francés: la Agrupación Guerrillera del Alto Aragón, nacida asimismo como consecuencia de las invasiones de 1944 pero cuya génesis y evolución difieren profundamente del proceso que hemos analizado en el caso de la AGLA.

\section{La Agrupación Guerrillera del Alto Aragón y las organizaciones clandestinas en la provincia de Huesca}

A finales del año 45, el PCE en Francia comenzó a plantearse seriamente la posibilidad de organizar a los grupos guerrilleros dispersos en la provincia de Huesca, al igual que se estaba haciendo en Teruel y Levante. Para esta misión se propuso a Joaquín Arasanz, natural de La Fueva y que ya había realizado una labor guerrillera en la zona durante las invasiones

206 Tomás Cossías, La lucha contra el «maquis»..., op. cit., p. 125. Informes AGLA, Archivo del Comité Central del PCE, sección Movimiento Guerrillero, Equipo de pasos, informes sobre camaradas, sign. 635-636. 
de 1944. Arasanz estaba de acuerdo en encargarse de esta tarea: «Conozco bien la región de Huesca, donde he vivido siempre, donde tengo simpatía y amistades. Yo puedo hacer un buen trabajo en España. Cuento con la simpatía de la región y podría sacarle dinero a la familia, con la cual sostengo correspondencia», alegó. ${ }^{207}$ Arasanz eligió un grupo de compañeros, naturales de la zona como él, para que le acompañasen en esta misión: se trataba de Manuel Tosán (natural de Monzón), José Moreno (también de Monzón), Manuel Cosculluela (de la zona del Sobrarbe) y Narciso Villellas (de Alquézar), guerrilleros procedentes como él del maquis francés y con un buen conocimiento de la zona. Ellos fueron el núcleo a partir del cual se articuló la Agrupación.

Joaquín Arasanz, el comandante Villacampa, era natural de Castejón de Sobrarbe, pequeño núcleo próximo al valle de La Fueva, y un personaje bien conocido por la población. Procedente de una familia republicana moderada, ingresó en el PCE en febrero de 1936. Durante la guerra ejerció diversos cargos de responsabilidad; estuvo en Teruel y en la batalla del Ebro, y posteriormente formó parte de la mítica 43. División (que, como vemos, fue una importante cantera de guerrilleros aragoneses), con la que cruzó la frontera por Port-Bou el 9 de febrero de 1939. Pasó por varios campos de concentracion franceses, ejerció diversos cargos políticos y se sumó a la Resistencia francesa, encuadrado en la UNE. En septiembre de 1944 se incorporó a la Brigada 21 de la 204 División como instructor, con la cual pasó la frontera en el marco de la Operación Reconquista de España, como ya se ha indicado. Tras volver a Francia pasó a formar parte del 4. ${ }^{\circ}$ Batallón de Seguridad como responsable del PCE, pero fue apartado de este puesto por haber hecho público un informe que el partido había ordenado mantener secreto, referente a la desmilitarización de los batallones de seguridad. Así que Arasanz fue sancionado y desmilitarizado como simple militante de base. Volvió a su casa de Puicheri, en Aude, hasta que recibió la orden de volver a España. ${ }^{208}$

En abril de 1946, el comandante Villacampa se introdujo de nuevo en Aragón por la línea fronteriza entre Huesca y Navarra, cerca de Echo. En

207 Autobiografía de Joaquín Arasanz, Archivo del Comité Central del PCE, sección Movimiento Guerrillero. Equipo de pasos, informes sobre camaradas, sign. 722.

$208 \mathrm{Ib}$. 
esta zona había ya guerrilleros que habían pasado la frontera con Amador Martínez, que ejercía funciones de guía entre Francia y el norte de Aragón. En un viaje realizado en noviembre de 1945, dos de los guerrilleros se habían quedado en Echo, donde organizaron una pequeña base guerrillera. En esta localidad también existía una red de enlaces. ${ }^{209}$ Pero Joaquín Arasanz y su grupo no se quedaron allí, ni tampoco en la sierra de Santo Domingo, que el grupo de Antonio ya había abandonado. Siguieron camino hacia el Este y se dirigieron hacia la zona de La Fueva, pero pasaron antes por la sierra de Lascuarre, donde creían que había un grupo de guerilleros. Efectivamente, otra partida permaneció en dicha zona después de 1944, la de Valeriano González, Drole, y Tanque, este último de filiación anarquista. Este grupo podría tratarse de un resto de la Brigada X, que estaba compuesta principalmente por anarquistas. Tras un infructuoso intento de conectar con las guerrillas de Extremadura, de donde eran originarios, el grupo había vuelto a Aragón y se instaló definitivamente, a finales de 1945 y principios de 1946, en los términos de Lascuarre, Roda de Isábena y Castigaleu. Éste fue el grupo con el que contactó Arasanz; en junio de 1946 se produjo un encuentro de los dos grupos en Las Almunias y quedó constituida la Agrupación Guerrillera del Alto Aragón. Arasanz fue nombrado jefe de la Agrupación. ${ }^{210}$

Debieron de existir otras partidas aisladas en la zona, pero lo más probable es que fuesen exterminadas o se dispersaran. Una de tales partidas fue desmantelada en enero de 1946 por un somatén compuesto de varios vecinos de Salinas de Hoz junto con cuatro guardias civiles. El grupo, formado por ocho guerrilleros, sufrió tres bajas, y el resto fueron hechos prisioneros. Los cuatro vecinos de Salinas de Hoz que participaron en la acción eran falangistas; uno de ellos era, de hecho, el alcalde de la localidad. El ataque provocó posteriormente la represalia de los guerri-

209 Ampliación de la biografía de Amador Martínez, Archivo del Comité Central del PCE, sección Movimiento Guerrillero, Equipo de pasos, informes sobre camaradas, sign. 66.

210 En un informe sin fechar, se da la siguienta composición de la denominada «Agrupación Guerrillera de Aragón»: Chacón, Manero, Paquer, Asturias, Jorge, Marcos, Eduardo, Pedro, Maja, Juanito, Tosán, Villacampa, Enrique, Gilberto y Narciso. Es decir, un total de quince guerrilleros. Pero, al no aparecer los nombres de Drole y Tanque, suponemos que se trata de una composición anterior a la reunión de Las Almunias. Archivo del Comité Central del PCE, sección Movimiento Guerrillero, Equipo de pasos, informes sobre camaradas, jacquet 29. 
lleros, que mataron al alcalde justo un año después, en enero de $1947 . .^{211}$ Las autoridades redactaban constantemente informes acerca del paso de partidas de hombres armados a través de la frontera. Se daba cuenta también del establecimiento de bases guerrilleras en la provincia de Huesca, así como del establecimiento de una base política en el partido de Benabarre, concretamente en el pueblo de Merli. Los servicios de información del Ejército informaban no sólo de la penetración desde Francia sino también de la adhesión de algunos jóvenes de la zona "próximos a incorporarse al servicio militar o que ya lo están cumpliendo, lo que justifica el aumento de deserciones y falta de incorporaciones que se registran en los últimos tiempos, puesto que les hacen creer que al incorporarse al "ejército de resistencia", como ellos le llaman a los "grupos de bandoleros", les sirve para cumplir el servicio militar y además les será reconocida la graduación que alcancen en el ejército regular que se organizará cuando consigan su victoria». ${ }^{212}$

La militarización de la zona, que se inició en octubre de 1944, continuó y provocó reacciones adversas en la población, que veía cómo las fuerzas militares acaparaban los recursos y hacían peligrar el abastecimiento de alimentos. Durante el año 1946, estas quejas alcanzaron su máxima intensidad; las protestas por la carestía de la vida y la superabundancia de fuerzas militares a las que había que alimentar eran constantes. ${ }^{213}$ Desde Francia, la propaganda comunista, tanto francesa como española, denunciaba también esta presencia de tropas en la zona fronteriza aragonesa y la calificaba de "provocación franquista", dado que, a primeros de marzo de ese mismo año, Francia había cerrado su frontera con España como protesta por el fusilamiento del guerrillero Cristino García. Realmente, como se recordará, era éste un momento de tensión e inseguridad para el régimen franquista, y durante los primeros meses del año se temió una invasión de guerrilleros procedente de Francia, apoyada por los partidos progresistas del país vecino. Mundo Obrero publicó una infor-

211 Jefatura Provincial de Huesca, informes mensuales, enero de 1946 y enero de 1947, AGA, sección Presidencia, DNP, caja 172.

212 Archivo del Gobierno civil de Zaragoza, sección Asuntos Gubernativos, caja 103, carpeta 5 .

213 Jefatura Provincial de Huesca, informes mensuales, febrero a octubre de 1946, AGA, sección Presidencia, DNP, caja 172. 
mación tomada de L'Humanité según la cual en la frontera de Aragón se encontraban, ese mes de marzo de 1946, seis divisiones de infantería, seis regimientos de artillería, un regimiento de caballería motorizada y uno de ingenieros. Y sobre todo se denunciaba la presencia de las odiadas «tropas moras» de los regulares, cuya presencia era temida tanto por los guerrilleros como por la población.

La actividad guerrillera, detenida mientras se organizaba la Agrupación y se coordinaba la actividad de los guerrilleros con la de los comités locales del PCE en Monzón y Barbastro, proceso que se describirá más adelante, se reanudó a partir de septiembre de 1946 . En esta fecha se produjo un asalto al recaudador de la contribución de Guaso, cerca de Eripol. Tuvieron lugar también varios ajusticiamientos, como el del alcalde de Arcusa, que al parecer «se había distinguido en la represión contra los antifranquistas». En enero de 1947 fueron asesinados el alcalde de Salinas de Hoz y un transportista de Graus del que se sospechaba que era confidente de la policía. En esta ocasión, parece ser que hubo una estrecha colaboración entre algunos vecinos y los guerrilleros. El transportista delataba a la policía los casos de estraperlo que se daban en la zona (según todos los indicios, pequeño estraperlo de supervivencia); de acuerdo con un testimonio recogido en Graus, los habitantes del valle de La Fueva (del que, como se recordará, era natural Villacampa) lo denunciaron a los guerrilleros y éstos lo ejecutaron. Pero el mismo mes de enero la policía armada hizo prisionero a Arasanz en la central eléctrica de Huerta de Vero, donde la AGAA tenía instalada una emisora clandestina, y con ello comenzó el declive de la guerrilla oscense. ${ }^{214}$

Hacia el año 1942 se había constituido en Monzón una pequeña célula comunista en torno a Joaquín Saludas, con el que el grupo de Arasanz tomó contacto poco después de su llegada a España. De este núcleo formaban parte también: Santiago Casanovas, como secretario de Organizacion del Comité Provincial y de Propaganda del Local de Monzón; Lorenzo Sierra, como secretario del Local de Monzón; y un tal Cabrera, que había vuelto de Francia en 1944, momento en que se incorporó a la

214 Jefatura Provincial de Huesca, informes mensuales, enero de 1947, AGA, sección Presidencia, DNP, caja 172. El entrecomillado, en Informe de Manuel Tosán. Archivo del Comité Central del PCE, sección Movimiento Guerrillero, Equipo de pasos, informes sobre camaradas, sign. 544. Entrevista, informante anónimo (guardia civil retirado), Graus, 16 de agosto de 1998. 
organización. Arasanz envió a Monzón a Tosán y Moreno, que tenían conocidos y familiares en esta localidad, para que estableciesen contacto con el PCE. El contacto se realizó a través de un hermano de Tosán, que fue el que los puso en relación con Saludas. Los dos guerrilleros se quedaron en Monzón durante un par de meses, tiempo en el que estuvieron escondidos en casa de los padres de Tosán. Además de las relaciones establecidas con el grupo de Saludas, los guerrilleros conectaron con Binéfar a través de un conocido de Moreno. También se organizaron apoyos en los pueblos de Sansebastián y Altorrincón. De este modo, se estableció una fructífera relación entre la guerrilla y la embrionaria organización comunista oscense. El enlace era frecuentemente realizado por el propio Arasanz, que al parecer contactaba en Monzón con una joven, Josefina Buil, en cuya casa se celebraban reuniones políticas y se acogía a los miembros de la célula comunista montisonense.

En Barbastro también existía, al menos en 1946, un núcleo comunista en el que participaban Ángel Bellostas, Ferrer y Salanova. Ferrer se encargó de establecer el contacto entre Barbastro y Zaragoza, y se tomó la decisión de organizar un Comité Local del PCE en Barbastro. También se había constituido la Alianza Democrática junto con delegados de la CNT. Tanto esta organización como la de Monzón cayeron en octubre del mismo año, a raíz de una operación de reparto de propaganda llevada a cabo por jóvenes reclutados en Monzón que hizo que la policía descubriese y detuviese a todos los participantes, lo que acabó con la estructura de la Alianza. En total, se produjeron 35 detenciones y se intervinieron una multicopista, armas y bombas de mano. El propio Saludas fue detenido, así como Josefina Buil, su padre y su hermano, y el PCE de Monzón prácticamente desapareció. Al parecer, fue entonces cuando Ferrer y Bellostas establecieron contacto con Villacampa; éste les comunicó que pasaban a formar parte del Comité Provincial del partido, formado también por varios guerrilleros. El grupo de Barbastro se encargaba de distribuir el periódico clandestino Aragón Libre, elaborado por los guerrilleros y tirado a multicopista. En realidad, ésta era la principal actividad del Comité de Barbastro. ${ }^{215}$

215 Informe sobre Ángel Bellostas, del Comité Local de Barbastro, Archivo del Comité Central del PCE, sección Movimiento Guerrillero, Equipo de pasos, informes sobre camaradas, sign. 540; y Jefatura Provincial de Huesca, informes mensuales, octubre de 1946, AGA, sección Presidencia, DNP, caja 172. 
Entretanto, Josefina Buil, una vez que salió de la cárcel de mujeres de Predicadores, en Zaragoza, reanudó su actividad política. La policía no había sospechado su importancia, y sólo fue condenada a seis meses y un día. Aprovechando las visitas que hacía a su padre en Torrero, logró establecer un enlace entre la guerrilla oscense y el Comité Provincial de Zaragoza; en aquel momento, el responsable del partido en Zaragoza era Antonio Rosel. Josefina hacía llegar Mundo Obrero a Huesca desde Zaragoza; su principal misión consistía en pasar documentación, y con ella colaboraban otras mujeres, sobre todo de la CNT, puesto que, como indica Josefina, la única posibilidad real de actuar era colaborando las distintas formaciones clandestinas de izquierdas. Dicha colaboración entre el PCE y la CNT no sólo se dio entre las mujeres, sino también entre los guerrilleros oscenses y, en general, en todo el ámbito de la clandestinidad altoaragonesa, cosa que no sucedía en el caso de Teruel, al menos no de esta forma: en la guerrilla turolense, por el contrario, la convivencia entre comunistas y cenetistas en el seno de la guerrilla solía ser fuente de conflictividad, como ya hemos tenido ocasión de ver. En Huesca, en cambio, se tomó en serio la consigna de colaboración entre todas las fuerzas antifranquistas en el seno de la Alianza Democrática.

Josefina fue detenida de nuevo en mayo de 1947, y entonces abandonó el trabajo que venía realizando y que se había vuelto demasiado peligroso. ${ }^{216}$ Además, la situación también había cambiado mucho, sobre todo a raíz de la detención de Joaquín Arasanz, que se produjo en enero de 1947. Esta detención marcó un antes y un después en la actividad guerrillera de la provincia, sobre todo porque Arasanz llevaba gran parte del peso de la organización sobre sus hombros. Los guerrilleros oscenses eran muy poco numerosos, y además se sentían «abandonados» por el partido (lo cual, de alguna manera, era cierto), y el ambiente entre ellos no se caracterizaba por una moral elevada o un alto grado de ideologización, lo que sí ocurría en la AGLA. Este ambiente es descrito en un informe del guerrillero Manuel Tosán al partido, en el cual se queja de que "no se hacía vida política ni se discutían las cosas que sucedían en reuniones». ${ }^{217}$

216 Testimonio de Josefina Buil. Graus, 20 de agosto de 1998. Entrevista sin grabar. Notas.

217 Informe de Manuel Tosán, Archivo del Comité Central del PCE, sección Movimiento Guerrillero, Equipo de pasos, informes sobre camaradas, sign. 544. 
En realidad, la Agrupación Guerrillera del Alto Aragón era, en cierto modo, una "Agrupación fantasma»; tanto es así que el nombre cayó finalmente un poco en desuso, y a partir de 1948 era denominada "Agrupación guerrillera de Levante y Aragón-sector Aragón», a pesar de que no había contacto entre ambas organizaciones. ${ }^{218}$ La tarea de los guerrilleros oscenses no consistía realmente en la acción guerrillera sino en organizar el PCE en la provincia de Huesca y, en menor medida, mantener la zona de la frontera libre para el paso de enlaces o grupos de guerrilleros. Por tal razón, las actividades propias de un grupo guerrillero, como asaltos, sabotajes o ajusticiamientos, fueran tan escasas. Una excesiva actividad guerrillera en la zona habría desencadenado una fuerte reacción represiva, que no era conveniente para los intereses del PCE, y más teniendo en cuenta que se trataba de una zona fronteriza fuertemente militarizada. Pero esto provocó también que la dirección del partido en Francia se preocupase más bien poco de lo que sucedía con la agrupación altoaragonesa y sus hombres; le interesaba mucho más centrar su atención en otras agrupaciones, como la de Levante, cuya actividad era una inagotable fuente de publicidad para el PCE. La ayuda o la dirección recibida de Francia fue, por lo tanto, escasa, por no decir nula; la Agrupación se alimentaba, sobre todo, de la enorme energía desplegada por Joaquín Arasanz.

Así, la detención de Villacampa dejó a la AGAA en una situación de orfandad. A pesar de ello, y superado un primer momento de perplejidad, durante los años 1947 y 1948 se incrementó la actividad guerrillera en la provincia oscense. Sobre todo, se logró establecer una red de enlaces y colaboradores bastante importante, colaboradores que eran calificados de «resistentes» por los guerrilleros. ${ }^{219}$ Pero, al mismo tiempo, la precariedad de la organización guerrillera y la fuerte represión comenzaban a minar este movimiento de resistencia.

218 Por ejemplo, cuando Mundo Obrero publica la noticia de un asalto de los guerrilleros al pueblo de Baldellou, los denomina «fuerzas de la AGLA que actúan en Huesca». Mundo Obrero, 5/8/48. Edición de París.

219 El uso de este vocabulario, en el que se trasluce la influencia de los conceptos tomados de la Resistencia francesa, es digno de mención, pues no es habitual en la zona de Teruel-Levante. 


\subsection{2. «Franco es la guerra»: 220 los años de apogeo (1947-1948)}

\section{Reestructuración de las agrupaciones aragonesas}

Durante el año 1946 se habían producido varios hechos de crucial importancia para el desarrollo de la guerrilla en el interior de España. Por una parte, la condena del régimen franquista por la ONU permitía abrigar algunas esperanzas a la oposición, aunque condicionadas por lo matizado de esta condena, que no proponía medidas concretas sino que instaba a los españoles a dirimir sus conflictos "por ellos mismos». ${ }^{221}$ Por otra parte, la ejecución en febrero de 1946 de Cristino García, Manuel Castro y ocho guerrilleros más provocó una fuerte reacción de repulsa internacional, que en Francia se tradujo en el cierre de la frontera el 1 de marzo de 1946. ${ }^{222} \mathrm{Al}$ mismo tiempo, desde el órgano del PCE editado en Francia, Mundo Obrero, se anunciaba que en el interior de España se había realizado "la unidad de las fuerzas republicanas», con la entrada del PCE en la Alianza Democrática (nombre por el que se conocía a la ANFD) y la autodisolución de la Junta Suprema de Unión Nacional (JSUN). ${ }^{223}$ Pero en la práctica y en el interior de los grupos guerrilleros el tema de la unidad es bastante más complejo, como hemos tenido ocasión de comprobar. Lo cual no impide que las llamadas a la unidad fuesen muy frecuentes en la prensa comunista, así como la propuesta de crear un Consejo Nacional de la Resistencia en el interior del país; dada la primacía, en esos momentos, del PCE en la lucha armada, la puesta en pie de un Consejo Nacional de la Resistencia sería una forma de asegurar el control del PCE en la resistencia interior, o dicho de otro modo, de volver a refundar la desgastada JSUN con un nuevo nombre y una nueva legitimidad.

En suma, gracias a las perspectivas internacionales, a la adhesión de numerosos simpatizantes del interior y a las expectativas creadas con la

220 El Guerrillero. Órgano de la Agrupación Guerrillera de Levante, febrero de 1949.

221 Esta condena al régimen franquista fue tan relativa que dio pie a las autoridades falangistas para informar en marzo de 1946 acerca del «desconcierto" de los comunistas "por el poco ambiente, incluso moral, que encuentran [...] Les decepciona más que ninguna otra cosa las declaraciones extranjeras de que el régimen español ha de ser cambiado por los mismos españoles». Jefatura provincial de Zaragoza, informes mensuales, marzo de 1946, AGA, sección Presidencia, DNP, caja 189.

222 Mundo Obrero, 23/2/46. Edición de Toulouse.

223 Mundo Obrero, 16/2/46. Edición de Toulouse. 
entrada del PCE en la Alianza Democrática, 1947 fue desde sus comienzos un año de intensa actividad guerrillera. Pero, paradójicamente, también fue un momento de crisis en el movimiento guerrillero aragonés: en el curso de ese año, las dos agrupaciones guerrilleras perdieron a sus jefes debido a la creciente represión, y además cayó una parte importante de la incipiente organización comunista zaragozana.

En enero de 1947 se produjo la detención de Joaquín Arasanz, y en marzo Vicente Galarza, Andrés, el jefe de la AGLA, fue detenido en Valencia en el piso donde tenía establecida su base, en una operación policial llevada a cabo durante los meses de enero y febrero. Posteriormente, fue ejecutado. En la misma redada cayó un enlace del $17 .^{\circ}$ sector, que también vivía en Valencia y que arrastró consigo gran cantidad de enlaces y puntos de apoyo. ${ }^{224}$ Asimismo en marzo se detuvo en Teruel a Jesús Maella, que efectuaba el enlace entre Teruel y Zaragoza, y a su contacto en la capital, Mariano Martí, natural de Épila. Éste había pasado a Francia al terminar la guerra para regresar clandestinamente en noviembre del 46, tras haber sido alumno de la Escuela de Cuadros de Toulouse. En su declaración, confesó ser jefe provincial y enlace con Teruel, encargado de la organización del PCE en la capital. El propietario del domicilio de Mariano Martí, al que se imputaban "antecedentes anarquistas», también fue detenido, así como siete individuos más, a los que se les requisaron varias pistolas y un ciclostil. Todos ellos fueron calificados de «elementos comunistas en connivencia con los bandoleros». Tras estas detenciones, la organización en Zaragoza capital quedó seriamente dañada. ${ }^{225}$ Durante el verano del año 47 cayó otra parte de la organización existente en la provincia de Zaragoza, concretamente en Luna y en Agüero; probablemente, se trataba de una red de apoyo que estaba en contacto con el grupo de guerrilleros encabezado por el Sos y el Tuerto de Fuencalderas. La acción policial tuvo lugar tras dos atracos cometidos en las localidades de Ardisa y Erla, y supuso la detención de siete vecinos de Luna que, según el informe de la guardia civil, «estaban constituyendo un comité revolucio-

224 Informe sobre la Agrupación Guerrillera de Levante, 3 de junio de 1947, Archivo del Comité Central del PCE, sección Movimiento Guerrillero, Equipo de pasos, informes sobre camaradas, jacquet 13 .

225 Archivo del Gobierno Civil de Zaragoza, sección Asuntos Gubernativos, caja 103, carpeta 11 . 
nario en Luna». ${ }^{226}$ Finalmente, en enero de 1948 se detuvo a varios enlaces y miembros de la partida del Sos y el Tuerto que se habían ocultado en Madrid. ${ }^{227}$

Un detalle que llama la atención al analizar la evolución del movimiento guerrillero en Aragón es el hecho de que no se produjera prácticamente ningún contacto entre las organizaciones que operaban en las provincias de Huesca y de Teruel, y más teniendo en cuenta que en ambas zonas actuaban guerrilleros comunistas que reunían características similares, como el hecho de ser aragoneses de origen y haber participado en la Resistencia francesa y en las invasiones de 1944. Además, ambas agrupaciones, cada una por su cuenta, mantenían alguna relación con la organización clandestina del PCE en Zaragoza, que, como hemos visto, quedó muy afectada por las detenciones producidas en la primera mitad de 1947. Asimismo, los guerrilleros procedentes de Francia con la misión de unirse a la AGLA no pasaban por la zona de acción de Villacampa y los guerrilleros de la AGAA, sino que atravesaban la frontera por la zona de Echo, en la que existían enlaces establecidos por Amador Martínez. Es decir: cruzaban la provincia de Huesca por la vertiente opuesta a la zona dominada por la AGAA. Todo ello pone en tela de juicio la justificación comúnmente utilizada para explicar la escasa actividad guerrillera de la Agrupación altoaragonesa, es decir, que tenía la misión de preservar la zona como paso para los enlaces, puesto que los enlaces no pasaban por allí.

Sin embargo, el contacto fue buscado por los guerrilleros: concretamente, a Antonio le interesaba de manera especial contactar con la organización altoaragonesa. A mediados de 1947, en la AGLA se conocía la existencia de un movimiento guerrillero en Huesca y la detención de Villacampa. Doroteo Ibáñez averiguó que un tal Luis, zaragozano que enlazaba Zaragoza con Valencia, conocía a la muchacha de Monzón

226 Memoria de la Comandancia de la Guardia Civil de Zaragoza. Centro de Estudios Históricos de la Guardia Civil, Dirección General de la Guardia Civil.

227 Archivo del Gobierno Civil de Zaragoza, sección Asuntos Gubernativos, caja 102, carpetas 6-10. Los detenidos eran Manuel Gálvez, el Sevilla o el Aguanta; Gonzalo Callejas (enlace); y Gabriel Cruz, el Madriles, que también perteneció al grupo guerrillero y que además era dirigente de la organización central, por lo que quedó a disposición del juez especial para la represión de la masonería y el comunismo. 
(Josefina Buil) que hacía el enlace entre Zaragoza y la guerrilla oscense. Ésta había sido detenida en mayo del 47; cuando saliese de la cárcel, por medio de ella se lograría enlazar con Villacampa y se conocería la situación del PCE en Zaragoza. Un objetivo que perseguían los guerrilleros levantinos era intercambiar armas entre ambos grupos, puesto que los de Huesca tenían muchas metralletas y pocos fusiles individuales, al contrario de lo que sucedía en Levante. Finalmente, el 11 de junio de 1947 se consiguió enlazar con Villacampa y se le llevó un informe a la cárcel. Pero éste no pudo proporcionarles información porque entonces ignoraba qué enlaces eran seguros y cuáles no, y estaba completamente aislado de la organización.

Por lo tanto, se logró contactar con Villacampa, pero no con la organización guerrillera. En realidad, los contactos entre los detenidos y el exterior eran bastante fluidos, y la información entraba y salía de las cárceles con relativa facilidad gracias a la habilidad de los presos, capaces de escribir los informes en papeles diminutos y ocultarlos en lugares inverosímiles, y a la de sus enlaces en el exterior. En comparación, los guerrilleros estaban aislados y mal informados; de ello es un ejemplo expresivo el hecho de que, precisamente, el contacto de la AGLA con Villacampa tuviese lugar cuando éste se hallaba en prisión, $\mathrm{y}$ no antes.

$\mathrm{Y}$ es que, realmente, parece que la organización altoaragonesa estaba bastante abandonada por los mandos comunistas franceses, que daban prioridad al desarrollo de la guerrilla en otras zonas como Galicia o Levante; así lo denunció Antonio Beltrán, el Esquinazau, veterano comandante

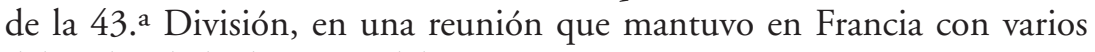
delegados de la dirección del PCE:

En el desarrollo de la lucha en el interior se ve por parte de la dirección del P. un favoritismo a desarrollar la lucha en ciertas regiones, no sé por qué. ¿Es que no tendría importancia crear núcleos guerrilleros a todo lo largo de la frontera francesa, paralelos a ella, y enlazar estos grupos con los que luchan más al interior? No se hace así. Hay lucha en Galicia, Andalucía, Levante. ¿Por qué no en Navarra, Cataluña, Aragón? Lo que hay en el norte de Aragón y nada es lo mismo. Estáis dando preferencia a organizar el P. y esto es una equivocación. Si queréis organizar el P. debe hacerse paralelamente a la lucha. Pero no olvidar el problema fundamental de desencadenar la lucha guerrillera en toda la Península, sin favoritismo [...]. 
En opinión de Beltrán, como vemos, la organización militar debía primar sobre la reconstrucción política, pero no era así. Muchos de los propios guerrilleros no compartían este punto de vista y concedían primacía a la "vida política» en el seno de la guerrilla, concibiendo ésta como un instrumento para la reconstrucción del PCE, en lo que coincidían con la dirección. Pero se trataba de guerrilleros como Antonio, venidos de Francia, fuertemente politizados y con una formación teórica importante. Curiosamente, en un informe de la Escuela de Cuadros de Toulouse, por la cual pasó Antonio, se le consideraba más apto como cuadro político que como jefe guerrillero. No deja de resultar paradójico. ${ }^{228}$

Tras la detención de Arasanz hubo un momento de perplejidad entre los guerrilleros oscenses, que habían perdido su cabeza visible. Fue Ángel Bellostas, responsable hasta ese momento del Comité de Barbastro, quien se hizo cargo de la Agrupación, auxiliado por Enrique Vistué, enviado por el partido desde Francia y que actuaría como responsable político. Los días 14 y 17 de mayo de 1947 atracaron a sendos recaudadores de la contribución en San Esteban de Litera y realizaron diversos actos de propaganda. En noviembre del mismo año murieron tres guardias civiles en Bierge. E ininterrumpidamente las fuerzas del orden daban cuenta del paso de «elementos sospechosos» a través de la provincia, lo que parece indicar que la AGAA se dedicaba más a la creación y coordinación de redes políticas que a la realización de actividades guerrilleras propiamente dichas, como sabotajes o ejecuciones. En tal sentido, su actuación se diferencia mucho de la que desarrollaba la AGLA. Además, se preocuparon de granjearse las simpatías de la población e intentaron organizar "grupos de resistencia» en el mayor número de poblaciones posible. En este aspecto, su radio de acción se redujo a las comarcas de Sobrarbe y Ribagorza, aunque también en La Litera (por ejemplo, en la estación de Tamarite Ventafarinas) lograron establecer grupos locales de resistencia. En suma, los guerrilleros altoaragoneses realizaron una labor de carácter mucho más político que militar.

228 Informes sobre la situación interior y exterior, Archivo del Comité Central del PCE, sección Movimiento Guerrillero, Equipo de pasos, informes sobre camaradas, sign. 123 y 186. En esta reunión intervinieron también Claudín, Julián, Losa, José Ramón, Espejo y Camaño, y se puede fechar en 1947 por una referencia del documento a la reincorporación de De Gaulle a la vida política francesa tras su retirada en enero de 1946. El informe sobre Ángel Fuertes Vidosa, en Archivo del Comité Central del PCE, sección Movimiento Guerrillero, informes sobre camaradas, sign. 824. 
La base de la guerrilla altoaragonesa quedó definitivamente establecida en peña Montañesa, y las acciones de los maquis se fueron restringiendo a un radio cada vez más corto a medida que iba pasando el tiempo. En esta etapa, la guerrilla estaba dividida en cuatro zonas: zona del Drole, que comprendía la Ribagorza; zona del Americano, en la que entraba La Litera y la ribera del Cinca; zona de Narciso, en los Monegros, el Somontano de Barbastro y Huesca; zona de Manuel Cosculluela, que se extendía por el Sobrarbe y La Fueva. Como puede observarse, las zonas de actuación estaban más al sur y al este de lo que habitualmente se piensa, ya que el Pirineo era una zona de paso. Además, no sabemos apenas nada acerca de los grupos anarquistas, que, indudablemente, actuaron en la provincia al margen de la AGAA. En cuanto a los efectivos de la Agrupación, es imposible hacer una estimación exacta, aunque en ningún caso los grupos sobrepasaban los siete a diez hombres. Otra cosa es calcular los apoyos con los que contaron en el seno de la población, que fueron bastante más numerosos. Los guerrilleros altoaragoneses consiguieron organizar redes de resistencia en un total de 66 núcleos de población, aunque hay que señalar que en algunas de estas poblaciones la «organización» del partido se reducía a un solo militante, como ocurría en el Raval de Huesca, Sueves o Eriste. Pero en otras existía una nutrida red: en una redada, la guardia civil detuvo a más de ciento cincuenta campesinos de los pueblos de Capella, Lascuarre, Puente de Montañana, Las Almunias, Monte Roda y Castigaleu. ${ }^{229}$

Volvamos la vista hacia lo que ocurría en el mismo momento en la zona de Levante. La muerte en Valencia de Vicente Galarza, Andrés, el jefe de la AGLA, se produjo en un momento de cierto desmoronamiento de la estructura de la Agrupación, con la casi desintegración del 5. ${ }^{\circ}$ sector, a cuyo frente estaba el desaparecido Delicado, una fuerte represión y un incremento de la actividad guerrillera. Por lo tanto, Antonio, que era jefe del 17. ${ }^{\circ}$ sector, pasó interinamente a hacerse cargo de la Agrupación bajo el nombre falso de Alfredo y a la espera de que la dirección del PCE designase cuanto antes a un sustituto. Ante tal situación de crisis, Ibáñez fue

229 Relación de camaradas en Huesca, sign. 666. Relación de miembros de la Resistencia en la provincia de Huesca, sign. 594. Nombres y características de militantes del Partido, de resistentes simpatizantes, de gente honrada del pueblo, indicando si están en libertad. Fechado h. 1950, sign. 470, Archivo del Comité Central del PCE, sección Movimiento Guerrillero, Equipo de pasos, informes sobre camaradas. 
enviado a Francia para informar del estado de la Agrupación. Ibáñez trasladó las inquietudes de Antonio a la dirección del PCE en Francia, insistiendo sobre todo en que había que buscar un jefe para la Agrupación que no fuera el propio Antonio y que debía residir en Valencia, y no en el monte. En ese momento, la Agrupación constaba de unos doscientos o doscientos diez hombres, y tenía sus bases en Albarracín y los montes Universales. Antonio propuso a Beltrán, el Esquinazau, por su popularidad al frente de la 43. a División, puesto que era consciente de la necesidad de un jefe carismático para atraerse a la gente. De modo casi anecdótico, añadía en su informe que no trajesen a Vicente López Tovar, que había dirigido la 204 División en la Operación Reconquista de España, «pues es muy mujeriego y muy dura la vida en el monte». La excusa no parece, en principio, seria: quizá Antonio estaba pensando más bien en las reticencias de López Tovar respecto a la actuación de sus superiores políticos.

Otra preocupación que Antonio transmitió a la dirección fue la falta de fondos, que impedía aumentar la actividad guerrillera:

Nuestros mayores obstáculos son los medios de subsistencia ya que pagamos todo al contado; recientemente hemos pasado una época de apuros a causa de una reciente incorporación que nos cogió casi sin fondos. En realidad nos pasamos hasta las dos terceras partes del tiempo en procurarnos el dinero necesario, hasta el punto de que muchas veces vamos desde el primero hasta el último en busca de dinero. Si este problema estuviera resuelto, nuestras acciones de tipo político se triplicarían, pues unas veces por la falta de información y otras por ser defectuosa nos fallan muchas recuperaciones.

Esta preocupación de Antonio revela la importancia que tenía para los guerrilleros pagar a los campesinos por los artículos que consumían, para no pasar en ningún momento por bandoleros, que era el calificativo que les aplicaba el régimen. Pero, al mismo tiempo, la falta de fondos les obligaba a realizar "golpes económicos», que suponían una buena publicidad cuando se trataba de las llamadas «recuperaciones», es decir, asaltos a recaudadores de la contribución o funcionarios de Abastos, por ejemplo, con lo que, según el punto de vista de los guerrilleros, el dinero del pueblo volvía al pueblo. Sin embargo, eran mucho más impopulares los secuestros y atracos a campesinos, aunque fuesen ricos; en estos casos funcionaba la solidaridad y la identificación entre miembros de la comunidad, y los campesinos se sentían amenazados como colectivo ante un posible ataque guerrillero. Probablemente, el PCE disponía de fondos para paliar 
este problema. Antonio Beltrán, en la reunión citada anteriormente, se quejaba de que no se enviase más dinero a los guerrilleros:

Hacemos mucha propaganda. Se gastan muchos millones. Pero llega poco dinero a los guerrilleros. Menos propaganda y más hechos. Hay muchos gastos. Yo me lo supongo. Estamos sacrificando a medio mundo para que nos ayuden. Pero la realidad es que gastamos más aquí de lo que se dedica allá. En eso de las colectas, las fiestas, hay una corriente de opinión contraria que está tomando carácter internacional, en la que denuncian estos hechos y atacan al $\mathrm{PC}[\ldots]$.

Debido a su posición crítica y a su independencia en un organismo tan jerarquizado como el PCE, sobre todo en la época que nos ocupa, no es extraño que Beltrán no fuese propuesto en ningún momento como jefe de la AGLA, como sugerían Antonio e Ibáñez. ${ }^{230}$

Otro de los problemas a los que se enfrentaba la Agrupación era la incorporación masiva a principios de 1947 de unos treinta hombres al 17. ${ }^{\circ}$ sector, que correspondía, a grandes rasgos, al Maestrazgo turolense y a la que se alude en un párrafo anterior. Se trataba de gentes procedentes de las minas de Utrillas y en su mayor parte cenetistas, "lo cual —indica Antonio en su informe a la dirección - no hubiera supuesto ningún problema si los camaradas de casa hubieran sido un poco conscientes. Por estas razones y según el punto de vista que tengáis sobre el movimiento guerrillero creo que es ahora cuando sería interesante y efectivo el envío de cuadros medios de casa y guerrilleros de la base conscientes y dispuestos a todo». Por lo tanto, el interés de Antonio no era tanto disponer de gran número de guerrilleros como el hecho de que éstos fueran "conscientes» $\mathrm{y}$ siguiesen la línea política marcada por el PCE. A la falta de esta conciencia política atribuye Antonio, por ejemplo, las deserciones: de este grupo de treinta hombres, en abril ya habían desertado cuatro. En los diferentes informes enviados a Francia por Antonio se trasluce su preocupación porque en la guerrilla se hiciese "vida del Partido", así como el enorme esfuerzo desplegado por los guerrilleros más «conscientes políticamente», colocados

230 Informe de Ibáñez, Archivo del Comité Central del PCE, sección Movimiento Guerrillero, Equipo de pasos, informes sobre camaradas, jacquet 3-9 [Agrupación Guerrillera de Levante], informe del 3 de junio de 1947, Archivo del Comité Central del PCE, sección Movimiento Guerrillero. Opinión de Beltrán, en informe sobre la situación interior y exterior. 
en los puestos de mando, para unificar ideológicamente la guerrilla, cosa que nunca se llegó a conseguir del todo.

Sin embargo, en estos momentos las soluciones expeditivas (como las aplicadas al Petrol o a Delicado) sólo eran empleadas en casos muy concretos, cuando se sospechaba de una posible traición o deserción. Una solución de este tipo se aplicó a Federico Bada, secretario comarcal de la CNT en la zona minera de Utrillas y unido a la AGLA, porque se sospechaba que estaba preparando una escisión en el seno de la guerrilla. Lo cierto es que Bada estaba en contacto con miembros de la Comarcal de la UGT en su zona, junto a los que preparaba la formación de la ANFD. Pero, al parecer, debió de llevar el asunto al margen de los mandos comunistas, que lo interpretaron como una traición, lo juzgaron y lo ejecutaron. Este asunto está relacionado, además, con el ingreso masivo de miembros de la CNT en la guerrilla, que huían de la redada que se produjo muy poco después de organizarse la ANFD en Utrillas. De ahí también las sospechas que recayeron sobre Bada, al que se acusaba de haberlos prevenido de la acción policial y, por tanto, de estar vendido a la policía. ${ }^{231}$

Finalmente, Antonio fue ratificado por la dirección francesa en su puesto de jefe de la AGLA en octubre de 1947. Antonio era, hasta ese momento, jefe del $17 .^{\circ}$ sector, por lo que su nombramiento como jefe de la Agrupación obligó a reestructurarla. El cambio más importante fue la división del $17 .^{\circ}$ sector, en razón del terreno y número de hombres que ocupaba, sobre todo tras las nuevas incorporaciones, en dos sectores, con la creacion de un sector nuevo, el $23 .^{\circ}$, que ocupaba la franja más oriental del antiguo $17 .^{\circ}$ sector, es decir, parte del Maestrazgo turolense y en especial castellonense. Al frente del $17 .^{\circ}$ sector, Antonio colocó al guerrillero Manso, uno de los primeros en llegar a la zona procedente de Francia. Germán Amorrortu, Manso, de origen vasco, había pasado la frontera en las invasiones de octubre de 1944, y, como vimos en el capítulo dedicado a éstas, también era muy crítico respecto a cómo

231 Agrupación Guerrillera de Levante, informe del 3 de junio de 1947, Archivo del Comité Central del PCE, sección Movimiento Guerrillero, Equipo de pasos, informes sobre camaradas. El caso de Federico Bada, informe sin fechar, Archivo del Comité Central del PCE, sección Movimiento Guerrillero, jacquet 39, y Gaudioso Sánchez Brun, "Aportaciones documentales para el estudio del maquis...", op. cit., pp. 211-219. 
se llevó a cabo la operación en su aspecto militar. Por lo demás, se trataba de un veterano de la Resistencia francesa, llevaba más de diez años militando en el PCE y gozaba de la confianza total de Antonio. Al mando del $5 .^{\circ}$ sector se puso al guerrillero Gil, que ya se había hecho cargo de éste tras la muerte de Delicado. En cuanto al $23 .^{\circ}$ sector, se colocó a su frente a Jesús Caellas Aymerich, Carlos. Se trataba de un guerrillero joven, procedente de Solsona (Lérida) y que había militado en las Juventudes Libertarias. Se unió al grupo de Delicado en 1944, cuando éste pasó por su pueblo, y desde entonces pertenecía a la AGLA. Quizá su antigua militancia libertaria fue considerada útil por Antonio para nombrarlo jefe de un sector que incluía a numerosos miembros de la CNT, aunque, en sus informes, Carlos hace gala de un comunismo sin fisuras, que podríamos calificar de sectario, y sus relaciones con los cenetistas de su sector, a los que califica de "provocadores», eran malas. Posteriormente, Carlos fue acusado por otros guerrilleros de llevar a cabo «eliminaciones» en el seno de la guerrilla. ${ }^{232}$

La reorganización de la AGLA se completó con la designación de Pepito como jefe del Estado Mayor; en dicho Estado Mayor ingresaron también, entre otros, los guerrilleros Zapatero y Mateo, que estaban en el grupo de Delicado. Da la impresión de que, al colocar a estos hombres en puestos de responsabilidad, Antonio quisiera evitar posibles resquemores por la muerte de su antiguo jefe, con quien habían llevado a cabo las primeras acciones guerrilleras. Antonio tomó también medidas en caso de «accidente» del jefe de la Agrupación, designando como su sucesor a Pepito. Antonio permaneció como jefe de la Agrupación hasta su muerte en un encuentro con la guardia civil en la masía Guimerá, en Castellón, el 26 de mayo de 1948 .

\section{Redes de resistencia y acciones guerrilleras en Huesca}

La actividad guerrillera desarrollada en Huesca es menos espectacular que la que tuvo lugar en la provincia turolense, zona guerrillera por exce-

232 Orden de la Agrupación n. ${ }^{\circ}$ 31. Firmada por Antonio el 31 de octubre de 1947, Archivo del Comité Central del PCE, sección Movimiento Guerrillero. Los datos sobre Manso, en Autobiografía de Germán Amorrortu, Manso, Archivo del Comité Central del PCE, sección Movimiento Guerrillero, informes sobre camaradas, sign. 621-622. Informe de Carlos sobre la AGLA desde octubre de 1944, Archivo del Comité Central del PCE, sección Movimiento Guerrillero, Equipo de pasos, informes sobre camaradas, sign. 629-631. 
lencia. Para empezar, los guerrilleros oscenses eran muy poco numerosos, $y$, por tanto, estaban en inferioridad de condiciones en caso de encuentro abierto contra fuerzas de la guardia civil o el ejército. Por otra parte, la provincia, y sobre todo la zona próxima a la frontera, se hallaba fuertemente militarizada. Las acciones de tipo guerrillero podían atraer sobre el grupo una cantidad de tropas que los guerrilleros no estaban en disposición de poder encarar, y esto hubiese llevado al grupo a su aniquilación. Por tanto, las razones tantas veces aducidas que presentan a los guerrilleros altoaragoneses como una especie de "guardianes de la frontera" deben ser matizadas. Sí entraban enlaces procedentes de Francia, pero su objetivo no era la AGLA sino los comités de Monzón y Barbastro o, incluso, Zaragoza. Los enlaces de la AGLA, como ya se ha indicado, entraban por el lado opuesto de la provincia, aprovechando los contactos de Echo y la zona de Agüero y Luna.

Sin embargo, la comunicacion entre la guerrilla altoaragonesa y Francia estaba asegurada, principalmente, a través de Amador Martínez, que realizaba frecuentes viajes a la zona para controlar la actividad de los guerrilleros y dotarles de material y propaganda. Amador Martínez también realizó varios viajes a la zona de Echo, donde había una base guerrillera no perteneciente a la AGAA y cuya función era, en este caso, dirigir a los enlaces hacia la zona de la AGLA. Aquí sí puede hablarse de preservar la zona como "zona de paso», pues era mucho más segura que los pasos del valle del Roncal o Lérida, muy vigilados por el ejército y la guardia de fronteras. La función de la AGAA era, ya hemos hablado de ello, organizar a los campesinos de la zona del Sobrarbe y la Ribagorza; según Martínez, en la zona, existía ya antes de la llegada de los guerrilleros una embrionaria organización del PCE. La gente comenzaba a organizarse, y demandaba ayuda del exterior. Ello influyó de forma significativa para que el PCE se decidiese a enviar a Arasanz y su grupo a este territorio. ${ }^{233}$

Martínez aseguró el enlace entre la AGAA y Francia hasta 1948, año en que fue trasladado a Asturias, su tierra natal, para comunicar a los guerrilleros asturianos la decisión del "cambio de táctica» tomada por el Buró

233 Ampliación de la biografía de Amador Martínez, Archivo del Comité Central del PCE, sección Movimiento Guerrillero, Equipo de pasos, informes sobre camaradas, sign. 66. Entrevista, Amador Martínez. París, 17 de febrero de 1998. Entrevista sin grabar. Notas. 
Político del PCE, aconsejado, al parecer, por Stalin. Este «cambio de táctica», que al parecer no fue sugerido a los guerrilleros altoaragoneses, consistía en una infiltración en los sindicatos verticales, para controlar desde dentro el aparato sindical franquista y conseguir logros para los obreros a partir de los resquicios legales permitidos por el propio sistema. Pero no eran los guerrilleros, fichados en todas las comandancias y comisarías, los más indicados para llevar a cabo esta táctica. Además, existen serias dudas ante el hecho de que existiese una voluntad efectiva de llevar a cabo ese cambio de táctica, como se ha descrito posteriormente en documentos generados por el PCE. Se trata, sin embargo, de un tema que desborda nuestro análisis.

Mientras Amador Martínez era enviado a Asturias a anunciar la nueva política del partido, el enlace era realizado, durante los años 1948 y 1949, por Antonio Cañete, de Córdoba, superviviente de Mauthausen y con residencia habitual en París. Para Antonio Cañete, la principal misión de la AGAA era difundir la política del PCE y crear organizaciones en las poblaciones; recuerda la AGAA como una guerrilla organizada desde el interior, con gentes del interior y que contaba sobre todo con la solidaridad de las gentes de la zona para mantenerse. El papel del PCE en Francia se limitaba en particular a dar orientaciones y proporcionar la propaganda, principalmente Mundo Obrero y Nuestra Bandera, que debía ser repartida en el interior. Por tanto, y como señalaba (o más bien denunciaba) Antonio Beltrán, el Esquinazau, la Agrupación Guerrillera del Alto Aragón era prácticamente autosuficiente. ${ }^{234}$

De este modo, la caída de Arasanz a comienzos de 1947 había puesto las cosas muy difíciles para la organización guerrillera, pues era él quien daba las directrices y quien mantenía el contacto con los comités del PCE en Monzón y Barbastro. Probablemente, el deseo de mantener ese contacto llevó a la jefatura de la AGAA a Ángel Bellostas, ante la falta de cuadros de que adolecía la Agrupación. El PCE envió desde Francia como refuerzo a Enrique Vistué, que ocuparía el cargo de responsable político. Los guerrilleros que habían pasado desde Francia con Arasanz eran hombres de acción, poco preparados para la labor política; por el

234 Entrevista, Antonio Cañete. Ivry-sur-Seine, 18 de marzo de 1998. Entrevista sin grabar. Notas. 
contrario, Ángel Bellostas carecía de preparación guerrillera, pero podía asegurar el contacto con el Comité de Barbastro, ya que las caídas de Monzón habían roto el contacto con esta última localidad. La acción de la AGAA se orientó hacia el proselitismo político y la propaganda, aunque también se efectuaron acciones de ajusticiamiento y algún sabotaje. Así, por ejemplo, en agosto de 1947 los alcaldes de la provincia recibieron un escrito circular firmado por el «Consejo Nacional de Liberación de España» en el que se les conminaba al abandono de sus cargos, aunque, en su mayoría, hicieron caso omiso. ${ }^{235}$ Más temor despertó la acción llevada a cabo en noviembre de 1947 y que costó la vida a tres guardias civiles, abatidos por un grupo guerrillero cerca de Bierge. Días antes, varios guerrilleros se habían presentado en esta localidad, donde penetraron en el café, amenazaron a los presentes y se encararon con dos agentes de la Fiscalía a quienes robaron el dinero, la documentación y algunas prendas de abrigo «sin que el resto de los concurrentes al establecimiento fueran en absoluto molestados». 236

Aquí topamos con uno de los problemas que más afectarían a la provincia de Huesca durante estos años, y que se entrelaza con el problema generado por la presencia de guerrilleros: la presión económica ejercida sobre la población. Esto no quiere decir que en el resto de la región aragonesa el problema no fuese importante, pero en Huesca marcó de forma notable las formas de conflictividad y generó un fuerte rechazo social, que se manifestó incluso en el enfrentamiento entre autoridades civiles y militares o en las acciones guerrilleras contra los representantes de la Fiscalía de Tasas, en el ejercicio de una especie de «justicia popular» que se manifestó de forma más visible que en Teruel. La fuerte militarización de la provincia, en efecto, tenía graves consecuencias para el abastecimiento de alimentos a la población, pues muchos de los recursos eran desviados para alimentar a las tropas. Ello generó multitud de protestas, que se canalizaron incluso a través de las Hermandades de Labradores y Ganaderos o de los propios alcaldes. Si a ello sumamos la presión de la Fiscalía, la situación económica de la provincia se presenta francamente problemática. Los guerrilleros eran cons-

235 Jefatura Provincial de Huesca, informes mensuales, agosto de 1947, AGA, sección Presidencia, DNP, caja 172.

236 Jefatura Provincial de Huesca, informes mensuales, noviembre de 1947, AGA, sección Presidencia, DNP, caja 172. 
cientes de este hecho y, dado que estaban muy conectados con la población, tomaron cartas en el asunto, como ya hemos visto en el caso de estraperlo del valle de La Fueva. Trataremos más a fondo el tema cuando hablemos de los posicionamientos del campesinado respecto a la guerrilla.

En enero de 1948 apareció muerto el guerrillero Tanque, muerte que nunca se llegó a aclarar del todo y que los guerrilleros atribuyeron a un accidente, ya que al parecer cayó por un terraplén y se le disparó la pistola. Ésta es la explicación que los guerrilleros recogieron en Monzón en el mes de mayo, ya que hasta ese momento no conocían la suerte que había corrido su compañero. Pero en el informe policial que da cuenta del hallazgo del cadáver de un guerrillero cerca del pueblo de Camporrells se indica que presentaba una herida de bala por la espalda. En todo caso, fue una muerte que desmoralizó bastante a las fuerzas guerrilleras y levantó sospechas entre sus integrantes, tal vez motivadas por la ideología anarquista de Tanque. De hecho, las primeras reticencias y problemas internos entre los guerrilleros eran anteriores al suceso, pero es arriesgado hacer un análisis acerca de esta cuestión puesto que sólo las conocemos por la declaración de Manuel Tosán a la dirección del partido en 1949, a su llegada a Francia; además, al tratarse de un grupo reducido de guerrilleros que convivían muy estrechamente, las diferencias personales y los roces podían ser frecuentes, sin que ello representase un indicio de disensión política.

En el caso de otro guerrillero, conocido como el Viejo, sí se produjo un ajusticiamiento. Se trataba de una persona natural de la zona, cuya identidad desconocemos, que se unió a los guerrilleros con la esperanza de pasar a Francia. Con nula preparación política o cultural, se dedicaba a sabotear el aprendizaje autodidacta de los guerrilleros, que se esforzaban en estudiar los documentos que les hacía llegar el PCE a través de Martínez, con frases como «zoquetes somos y zoquetes moriremos», lo que le acarreó rápidamente el consabido calificativo de "provocador». En vista de que su paso a Francia se demoraba y los guerrilleros le hacían permanecer con ellos, trató de escaparse por dos veces, y al final fue ajusticiado "porque ofrecía peligro entre nosotros y también si se hubiera escapado; ya que se hubiera entregado al enemigo y hubiera hecho mucho mal lo mismo en España que en Francia». ${ }^{237}$ En

237 Informe sobre Aragón: caída de Villacampa y muerte del Viejo, Archivo del Comité Central del PCE, sección Movimiento Guerrillero, Equipo de pasos, informes sobre camaradas, sign. 532 . 
este enfrentamiento percibimos de nuevo el choque cultural del que ya hemos hablado, así como un ejemplo de la incomprensión que suscitaba la cultura comunista entre ciertos individuos, que la encontraban absolutamente ajena a su mundo mental.

Este choque de culturas no impidió que los guerrilleros altoaragoneses contasen con una red de apoyos muy nutrida, teniendo en cuenta la baja densidad de población de las comarcas en las que se movían y las dificultades a las que se enfrentaban. En documentos del PCE se nombran hasta un total de 66 núcleos de población en los cuales los guerrilleros contaban con algún tipo de contacto. En cuanto a la distribución territorial, los apoyos se concentraban en las zonas próximas a la peña Montañesa y en las localidades de La Fueva. También disponían de redes en localidades alejadas de esta zona, como Monesma o la estación de Tamarite Ventafarinas. En los testimonios orales se afirma que en algunas aldeas prácticamente toda la población apoyaba a los guerrilleros. Dicho apoyo estaba sustentado, por un lado, en las relaciones personales establecidas con los guerrilleros, pero también, de forma muy notable, por la identificación con la lucha llevada a cabo por éstos, ya que las identidades políticas de la población se mantenían intactas desde antes de la guerra civil. En poblaciones próximas a la peña Montañesa, como Oncins o Los Molinos, el contacto con los guerrilleros (los «maquis») era casi cotidiano, y se habían establecido con ellos relaciones que entremezclaban lo político y lo personal.

La forma de reclutar los apoyos era sumamente tradicional, y a la vez efectiva: utilizaban las redes de parentesco que unían a personas de localidades diferentes para ir extendiendo la organización: «En las zonas donde actuaba la Agrupación en la mayoría de los casos entre los de un grupo de pueblos hay enlaces de familias y ocurría que se enlazaba con uno de éstos, nos llevaba a casa de un familiar que era de izquierdas y así se iban encadenando y conociendo todos los que integraban los comités de la resistencia». ${ }^{238} \mathrm{Al}$ mismo tiempo, es cierto que los guerrilleros eran portadores de un discurso nuevo, que en ocasiones resultaba difícilmente comprensi-

238 Informes sobre las caídas de Villacampa y otros en Monzón; acciones guerrilleras en Aragón, Archivo del Comité Central del PCE, sección Movimiento Guerrillero, Equipo de pasos, informes sobre camaradas, sign. 544. 
ble. En los guerrilleros de la AGAA encontramos una fuerte influencia del lenguaje propio de la Resistencia francesa; los colaboradores son denominados «resistentes», se crean "comités de resistencia», se habla de la "Liberación»... Un lenguaje ajeno a la mentalidad de los campesinos que eran reclutados para formar dichos "comités de resistencia».

Por otra parte, el apoyo conseguido se perdió de forma relativamente rápida debido a la represión, que, aunque alcanzó niveles menores que en Teruel fue lo suficientemente dura para desmantelar la red de resistencia. 1948 fue un año de continuas deserciones y caídas que llevaron al desmoronamiento de casi toda la red de resistencia tan trabajosamente puesta en pie. En primavera fueron detenidos en Blecua Enrique Vistué y Ángel Bellostas, que serían posteriormente fusilados en Zaragoza; en mayo se desmoronó toda la zona del Somontano de Huesca; en otoño, la policía acabó con la resistencia de Pertusa, Peralta, Alcolea, Torres de Alcanadre y Huerto; además, se descubrió la resistencia de La Fueva, y la policía logró desmantelar la mayor parte de su estructura. Las acciones guerrilleras, en respuesta a estas acciones policiales, también se radicalizaron: en julio de 1948 fueron asesinados los suegros del jefe local de Falange de Baldellou, así como su esposa, embarazada de nueve meses, y dos vecinos. Se trata de una acción realizada de forma tremendamente improvisada, en la cual los guerrilleros entraron en el pueblo en pleno día (cosa absolutamente imprudente) y respondieron a los disparos que el cura y varios lugareños hicieron desde las ventanas disparando a todo el que veían por la calle. Como revela Manuel Tosán en un informe posterior, «esta operación fue mal acogida por la población, la hicimos sin tener información, un poco fuimos a la aventura, nos metimos sin saber qué había en el pueblo». ${ }^{239}$

En agosto de 1948 los guerrilleros realizaron varios atracos a mano armada en diversos pueblos de la provincia, con lo que se logró recaudar unas cien mil pesetas, y sostuvieron un encuentro con la guardia civil en el que murió un guardia y dos resultaron heridos. Y en septiembre fue asesinado el alcalde de Barbuñales, lo que dio lugar a una nueva ola de deten-

239 Informes sobre las caídas de Villacampa y otros en Monzón; acciones guerrilleras en Aragón, Archivo del Comité Central del PCE, sección Movimiento Guerrillero, Equipo de pasos, informes sobre camaradas, sign. 544. Jefatura Provincial de Huesca, informes mensuales, julio de 1947, AGA, sección Presidencia, DNP, caja 172. 
ciones, gracias a las cuales se encontró en Albelda un depósito de armas y municiones. ${ }^{240}$ Ésta es la última vez que la guerrilla altoaragonesa aparece en los informes policiales, exceptuando las informaciones acerca de una infiltración anarquista producida en 1949; a partir de entonces, sólo contamos con las noticias proporcionadas por los propios guerrilleros oscenses para conocer los últimos momentos de su permanencia en el monte.

\section{La actividad guerrillera en Teruel}

Aparte de los problemas internos de la AGLA, lo cierto es que su actividad guerrillera se incrementó de forma espectacular a partir de finales de 1946, sobre todo en la provincia de Teruel. Ello coincidió con la llegada de informes cada vez más preocupantes a los despachos oficiales, informes que daban cuenta de una importante actividad de los exiliados españoles en Francia y que hacían temer la inminencia de una acción guerrillera a gran escala, procedente del país vecino. En diciembre, los gobiernos civiles recibían el siguiente comunicado:

Los exiliados españoles en Francia, especialmente los del PC y CNT, continúan incrementando sus actividades especialmente en los Departamentos del Alto Garona, Altos y Bajos Pirineos, Laude [sic], Ariege, Aude y Pirineos Occidentales, en estos últimos con menor intensidad, encaminando todos sus esfuerzos para preparar militarmente a los afiliados, lo que hace pensar en la posibilidad de que intenten llevar a cabo golpes de mano contra nuestra frontera, conjugando esta acción desde el exterior, con un plan de agitación, actos de sabotaje (se dice que intentarán volar un puente cerca de Jaca) y reclutamiento de rebeldes y que ya lo están llevando a cabo en las provincias de Granada y Ávila con algún éxito. Para precipitarlo y percatándose de las dificultades que encuentran para filtrar sus Agentes encargados especialmente de este cometido en territorio español, por la frontera hispano-francesa, se asegura que tratan de introducir por Almería y otros puntos de Levante de 1200 a 10000 hombres. [...] Entre éstos se sabe entrarán buen número de mujeres pues piensan que ellas les darán mejor resultado, por infundir menos sospechas [...]. ${ }^{241}$

A estas noticias tan inquietantes para el régimen se unía el hecho de que las personas que ocupaban cargos en la Administración o el aparato

240 Jefatura Provincial de Huesca, informes mensuales, septiembre de 1947, AGA, sección Presidencia, DNP, caja 172.

241 Archivo del Gobierno Civil de Zaragoza, sección Asuntos Gubernativos, caja 103, carpeta 11 . 
represivo franquista estaban en el punto de mira de los guerrilleros. En Teruel, entre noviembre y enero se produjeron cinco acciones guerrilleras de importancia, que provocaron la muerte de un guardia del puerto de Escandón y la del teniente de alcalde de Mosqueruela, Fabián Altaba. A ello se suma un secuestro en el barrio de San Blas (Teruel), el incendio de la casa de un falangista en Libros, el asalto del autovía Zaragoza-Tortosa y el asalto al Ayuntamiento de Calomarde, además de otros incidentes menores. El pánico cundió entre las autoridades falangistas, hasta tal punto que muchos puestos quedaron vacantes, como explicaba el jefe provincial del Movimiento y gobernador civil de Teruel, David Herrero:

Sigue notándose la falta de espíritu y colaboración para cubrir las numerosas vacantes que se producen en los ayuntamientos de la provincia y más todavía si son de jefes locales o delegados de servicios (muchas de cuyas vacantes son a peticion propia y otras pretextando el traslado de residencia) y que obedecen al temor reinante por la frecuencia de actos terroristas que vienen realizándose hace tiempo en distintas zonas. Hay gran descontento en este sentido, pues conociéndose son pequeñas bandas de salteadores, da la impresión que no se toman todas las medidas posibles para terminar con ellos y, por otra parte, las gentes no prestan colaboración a la fuerza pública, ya que aquellos que han dado algún informe, hecho denuncias o prestado ayudas, han sido vengados villanamente.

Explícitamente, el gobernador civil estaba pidiendo que se aplicase una mayor represión; su petición sería atendida pocos meses después, y llevaría aparejada su propia destitución. También se quejaba de la existencia de pequeños grupos de descontentos que se dedicaban «a la crítica, divulgación de bulos, etc. amparándose en el estado de dificultades o restricciones que padecemos. Este ambiente puede afirmarse que es general, y lo que realmente predomina es la ambición desmesurada de todos por las cortapisas que se ponen a sus deseos de lucro abusivo, y que redunda en perjuicio del humilde». Estamos ante un discurso anticaciquil típicamente falangista, que encubre el hecho de que la situación era realmente difícil tanto desde el punto de vista económico como desde el político, por las acciones cada vez más audaces de la guerrilla y la falta de colaboración de la población con las autoridades. ${ }^{242}$

242 Jefatura Provincial de Teruel, informes mensuales, noviembre y diciembre de 1946, enero y febrero de 1947, AGA, sección Presidencia, DNP, caja 183. 
Pero la falta de colaboración de la población no se debía tan sólo al miedo a las represalias, si bien es verdad que muchos campesinos vivían atemorizados por las acciones de la guerrilla (pero también por las acciones represivas llevadas a cabo por la guardia civil). Lo cierto es que había también un gran número de personas implicadas de una forma o de otra en las redes que los guerrilleros iban tejiendo en torno a sí: porque habían entrado en contacto con los guerrilleros, porque tenían entre éstos familiares o conocidos, porque se habían visto impelidos u obligados a prestarles ayuda... Muchas de estas personas habían sufrido represalias durante la primera posguerra por su condición de izquierdistas, y ello les hacía sentirse identificados de forma inmediata con el movimiento guerrillero. Otras no tenían una afiliación política definida, pero sentían simpatía hacia los guerrilleros, simpatía que éstos (sobre todo los más "conscientes», como diría Antonio) se preocupaban de fomentar, explicando ante los campesinos que los acogían los motivos de su lucha y los objetivos que perseguían. A menudo, estos campesinos, víctimas de arbitrariedades de todo tipo, agobiados por las imposiciones económicas y frustrados por la situación de miseria que se vivió en Aragón durante la década de los cuarenta, muy especialmente en Teruel, se sintieron atraídos por el discurso de los guerrilleros comunistas. $\mathrm{Y}$ esta atracción dependía también de la habilidad con la que éstos supieran presentarse ante los campesinos como defensores de sus intereses, hablando su mismo lenguaje y presentándose como luchadores desinteresados por la libertad y la democracia, palabras que tal vez no tenían un significado concreto para el campesinado, pero que abstractamente podían equiparar con menos cargas económicas (o mejor repartidas), menos abusos de la autoridad, mayor libertad para producir y para gestionar sus recursos y, en el caso de los masoveros pobres, un mejor reparto de la riqueza y un acceso a la tierra más equilibrado.

A medida que avanzaba el año 1947, las acciones de la guerrilla en Teruel se iban haciendo más osadas. En marzo, unos guerrilleros apresaron al cabo comandante de Las Parras de Castellote José Serrano Serrano, que apareció muerto al día siguiente, y durante ese mes se produjo una verdadera escalada de acciones violentas, entre ellas el asesinato de un vecino de Palomar de Arroyos y la voladura de un tren entre Sarrión y Barracas, con el resultado de la muerte del fogonero y el maquinista. En toda la provincia se vivía un ambiente de gran intran- 
quilidad. ${ }^{243}$ En mayo y junio, con la proximidad del referéndum del 6 de julio, aumentaron tanto las acciones guerrilleras como las precauciones de las autoridades. Pero, además, parecer ser que en Teruel había en ese momento otros grupos en activo al margen de la AGLA. El primero de mayo de 1947, en el km 32 de la carretera de Venta del Aire a Nogueruelas, una partida de ocho hombres armados detuvieron e incendiaron tres camiones y asesinaron al propietario y conductor de uno de ellos, Antonio Monforte, "por haber pertenecido siempre a partidos de derechas y de orden y desempeñar el cargo de alcalde de Mosqueruela algún tiempo a la terminación de la guerra de liberación». Los guerrilleros se identificaron como los «makis» del comandante Jorge (y no como guerrilleros de Levante, que es como se presentaban siempre los miembros de la AGLA). El comandante jefe de la guardia civil informaba de que el comandante Jorge se jactaba de haber pertenecido en la guerra a la Columna de Hierro. Parece, por tanto, que se trataba de una partida independiente, aunque la AGLA reivindicará esta acción porteriormente en un listado de las acciones efectuadas por la Agrupación durante 1947 que apareció en un suplemento especial de Mundo Obrero. ${ }^{244}$

La autoridades turolenses eran conscientes, también, de la relación existente entre la aparición de la guerrilla y la reorganización de los partidos de izquierdas en la clandestinidad. Tras producirse la explosión de un artefacto en la vía férrea al paso de un tren de mercancías por la vía Central-Aragón el 9 de mayo, el comandante 2. ${ }^{\circ}$ jefe que redactaba el informe expresaba la siguiente suposición: «El Jefe que suscribe es del parecer que este hecho haya sido perpetrado por individuos pertenecientes a partidos políticos de extrema izquierda, enlazados con las partidas de bandoleros». ${ }^{245}$ Pero no siempre estas redes de enlace revestían un carácter de organización política, ni suponían la reconstrucción de partidos o sindicatos. Por ejemplo, el 10 de mayo, en Libros, eran detenidos varios vecinos por

243 El cabo de Las Parras, en Memoria de la Comandancia de la Guardia Civil de Teruel (1966). Centro de Estudios Históricos de la Guardia Civil, Dirección General de la Guardia Civil. El resto de acciones guerrilleras, en Jefatura Provincial de Teruel, informes mensuales, marzo de 1947, AGA, sección Presidencia, DNP, caja 183.

244 AHPT, sección Gobierno Civil, caja 1085, carpeta 4. Mundo Obrero, suplemento especial, 1947.

245 AHPT, sección Gobierno Civil, caja 1085, carpeta 28. 
haber mantenido relación con Cristóbal Miguel Calvo, fugado de un batallón de trabajadores de Teruel, y al que se creía unido a los guerrilleros. Se sometió a interrogatorio a su familia y todos sus miembros resultaron detenidos, porque confesaron que le proporcionaban alojamiento, comida e información sobre los movimientos de la guardia civil. Por tanto, en Libros se había creado una "organización de resistencia» fundamentada en los lazos familares que unían a sus componentes con el guerrillero, y supeditada a proporcionar a éste ayuda de todo tipo; en la formación de dicha organización podemos adivinar motivaciones personales antes que políticas (sin descartar necesariamente estas últimas). ${ }^{246}$

Por otra parte, desde enero de 1947 había comenzado a funcionar una escuela guerrillera, dirigida por Pepito, en las proximidades de la localidad de Aguaviva. En ella se impartían clases tanto de formación política como técnica (fabricación de fulminantes, detonadores, etc.), y, según Antonio, era «más completa que la de Francia». El emplazamiento se eligió por la estrecha colaboración que existía entre la guerrilla y una gran parte de la población de Aguaviva, fomentada en gran medida por José Mir, el Cona, que había organizado la red de suministros y posteriormente tuvo que huir al monte y reunirse con los guerrilleros, al ser descubiertas sus actividades por la guardia civil. Pero, incluso desde el monte, José Mir siguió captando adeptos para la red de resistencia de Aguaviva, lo que le era facilitado, además, por su conocimiento de las gentes y del terreno. Lo curioso del caso es que se trataba de una persona de familia de derechas «[...] pero de toda la vida, ¿eh? De los... de los de delante. Que hay una familia en todos los pueblos». «[...] Y el tío Juan Manuel, que acabó llevándoles comida también a los maquis, que fue a la cárcel. De derechas». ${ }^{247}$ Por tanto, el Cona no sólo logró implicar a gente ideológicamente afín, sino también a miembros de su familia de ideología conservadora, que le ayudaban a causa de sus lazos familiares.

La escuela guerrillera de Pepito el Gafas sufrió ya el 14 de marzo de 1947 un serio ataque en el cual se hicieron prisioneros a dos guerrilleros, que serían fusilados más tarde en Las Parras de Castellote (razón por la cual se produjo la muerte del cabo de Las Parras, José Serrano Serrano, dos

246 AHPT, sección Gobierno Civil, caja 1085, carpeta 59.

247 Entevista, Joaquín Buñuel Mir y P. Z. Aguaviva, 6 de agosto de 1996. 
días después, como venganza por haber participado en los fusilamientos). Pero fueron los sucesos de junio los que provocaron la ola represiva que desplazó definitivamente a los guerrilleros de esta zona; el 9 de agosto, las fuerzas de la guardia civil llevaron cabo un asalto a gran escala en el pinar de Aguaviva, incendiándolo con el fuego de los morteros. Aguaviva se convirtió en una «zona quemada» (en el doble sentido del término), y la escuela guerrillera se trasladó a los montes Universales. ${ }^{248}$

El mes clave de este año 1947 fue julio. Por una parte, el día 6 estaba convocado el referéndum mediante el cual se iba a definir la naturaleza del Estado y con el que Franco pretendía legitimar y perpetuar su régimen. Por otra, dada la escalada de actividad guerrillera, las autoridades temían un 18 de julio especialmente conflictivo. Además, fue el mes en que comenzó la ofensiva más brutal del régimen contra el movimiento guerrillero y sus colaboradores civiles, reales o potenciales.

Para sorpresa de las autoridades, la primera quincena del mes fue relativamente tranquila, a pesar del referéndum. No sucedió lo mismo los días 17 y 18 de julio; el 17 se produjeron dos asesinatos en Albentosa y uno en Alcalá de la Selva. ${ }^{249}$ El día 18 los guerrilleros desplegaron una gran actividad: reparto de de propaganda, octavillas, despliegue de pancartas y banderitas republicanas, etc. También entraron en varios pueblos, en los que celebraron mítines. En la ciudad de Teruel se llevó a cabo un sabotaje en las instalaciones de la Sociedad Teledinámica Turolense. ${ }^{250}$ Pero la mayor concentración de sucesos se produjo en la zona de las cuencas mineras, con la colocación de varios artefactos explosivos y la aparición de propaganda.

Ante la proliferación de acciones en un terreno no muy extenso, se entrevistó a autoridades y "personas de orden» para averiguar quién había podido ayudar a los guerrilleros, en la creencia de que ellos solos no habían podido hacerlo todo, y se llegó a la conclusión de que «[...] existe la creencia general se haya llevado a efecto por algunos elementos contrarios al régimen que pululan por aquella cuenca minera o por algunos sujetos

248 AHPT, sección Gobierno Civil, caja 1086, carpeta 55.

249 AHPT, sección Gobierno Civil, caja 1086, carpeta 38. Memoria de la comandancia de la Guardia Civil de Teruel (1966). Centro de Estudios Históricos de la Guardia Civil, Dirección General de la Guardia Civil.

250 AHPT, sección Gobierno Civil, caja 1086, carpeta 34. 
que, camuflados como pordioseros, pasan desapercibidos por los pueblos y aprovechan esta circunstancia para cometer sus fechorías, actos vandálicos y adquirir noticias». No es casual que estemos hablando de una zona minera, en la cual había muchos obreros con un pasado sindicalista, principalmente ugetista, y donde, como veíamos al tratar el caso de Federico Bada, se estaba tratando de reconstruir estas organizaciones en la clandestinidad. Las minas de Utrillas proporcionaron también muchos efectivos a las guerrillas de la zona. ${ }^{251}$

Ante el general aumento de actividad guerrillera, tanto las autoridades locales, que demandaron refuerzos al Gobierno Civil y reactivaron la formación de somatenes, como la autoridad central decidieron tomar medidas expeditivas para atajar el problema. En otro capítulo nos dedicaremos específicamente a la represión que se desencadenó contra el movimiento guerrillero y sus colaboradores o sospechosos de serlo, es decir, contra una amplia franja de la población civil. Por el momento, apuntaremos que el mes de febrero de 1947 era nombrado gobernador civil de Teruel y jefe de la 5 . $^{a}$ Región Militar el coronel Manuel Pizarro, que pronto alcanzaría el grado de general y que puso en marcha una serie de medidas represivas de gran amplitud e intensidad. Además, el 18 de abril se promulga el Decreto-Ley para la Represión del Bandidaje y el Terrorismo. Con esta disposición y el nombramiento de Manuel Pizarro, el franquismo declaraba abiertamente la guerra a la guerrilla y a todos aquellos que tuviesen el más mínimo contacto con ella. De hecho, una de las disposiciones que tomó el nuevo gobernador civil fue declarar la provincia como "zona de guerra», lo que suponía una serie de medidas que restringían de manera importante la libertad de acción de la población, como el toque de queda o la prohibición de permanecer en los caminos después de las ocho de la noche. También decretó el desalojo de las masías aisladas en el monte, lo que conllevó para sus moradores la obligación de buscar alojamiento nocturno en los núcleos de población. Como este sector de la población coincidía en general con el más desfavorecido económicamente, podemos imaginar las consecuencias de tales medidas para las economías familiares.

251 AHPT, sección Gobierno Civil, caja 1086, carpeta 47. 
En esta guerra, las primeras víctimas eran, antes que los propios guerrilleros, sus familiares y colaboradores, principalmente las mujeres. Las represalias dieron en ocasiones lugar a terribles escaladas de violencia, como la que se vivió en la población turolense de Gúdar. El 28 de septiembre de 1946 murió Felisa Montoliu, en circunstancias no aclaradas. Esta mujer era esposa del guerrillero Florencio Guillén, el Viejo, que estaba al mando de un grupo, y madre del guerrillero Florencio Guillén Montoliu, Frasquito. Cuando murió se encontraba en poder de la guardia civil, que la había detenido, probablemente para hacerle confesar el paradero de los guerrilleros. La muerte de Felisa quedó sin aclarar: según los guardias se suicidó, pero parece que su muerte fue consecuencia de una paliza. Un año después, durante la madrugada del 28 al 29 de septiembre de 1947, un grupo de guerrilleros al mando de Florencio Guillén, natural de Gúdar, asaltó esta localidad, fusiló a nueve de los vecinos (todos miembros de una misma familia, y entre ellos dos niños) y puso una bomba en el cuartel de la guardia civil, que mató a varios guardias y, según algunas fuentes, a la esposa e hija pequeña del cabo (extremo que no hemos podido confirmar). El motivo de la violencia contra el cuartelillo es fácil de adivinar; en cuanto a la familia que fue aniquilada, era acusada por Florencio de haber denunciado a su mujer. A su vez, la acción del guerrillero desató una nueva oleada de detenciones. Se trataba, efectivamente, de una verdadera guerra no declarada.

Las muertes de Gúdar impresionaron fuertemente a la población por tratarse de una familia conocida, del pueblo, y por la aniquilación a la que fueron sometidos, que sólo dejó con vida a una niña de pecho:

Yo no más le puedo decir que yo subí a Gúdar la noche de San Miguel, el 29 de septiembre, aquella noche fue cuando los mataron. A nueve personas. Quién los mató, no lo sabemos. Los muertos eran gente del pueblo. Entre los muertos había una zagalica pequeña. Mamaba de los pechos de su madre y yo la levanté. La madre estaba muerta, sí. Fue allá en una era, y en la entrada de una bodega. Nosotros subimos el día 29. Eso fue el día 28 por la noche. Porque yo estaba en el Alto de San Rafael, de puesto. Y yo sentí todo el tiroteo. Fue el tiroteo a las tres de la mañana. Y dijeron, andá qué tiroteo, deben de ser los maquis, y entonces yo, como sentí el tiroteo y era de aquí, a los militares que estaban conmigo les dije: esto son las fiestas de Mora, que es San Miguel y hacen fiestas. Y así pasó, y eso es lo que creíamos nosotros. ¡Menudas fiestas! ${ }^{252}$

252 Transcripción de la conversación con Manuel Górriz, Carijo, en la masada El Masico, de Rubielos de Mora, 4 de enero de 1999, José Giménez Corbatón. Documento cedido por José Giménez Corbatón. 
Los llamados «ajusticiamientos» de chivatos o delatores eran una práctica que entraba dentro de las acciones guerilleras. Pero los hechos de Gúdar no se ajustan a la ética que propugnaban los guerrilleros, ni a su modo habitual de actuar. Normalmente, los guerrilleros ejecutaban al responsable directo de la delación, hombre o mujer, y solían dejar una nota sobre el cadáver donde se indicaba la acusación por la que había sido ajusticiado. Así hicieron con Ricardo Villanueva, de Alcalá de la Selva, sobre cuyo cadáver colocaron el siguiente mensaje: "Ajusticiado Ricardo Villanueva por delator de las Guerrillas y como ejemplo». O con una mujer, Ángela Gil, que fue encontrada ahorcada cerca de su masía de Mosqueruela un mes antes de los sucesos de Gúdar: «El que toque este cadáver será condenado a muerte en la horca. Ha sido ajusticiada por delatora, espía y agente de información del enemigo». A este último caso se le dio un tratamiento peculiar. La guardia civil, a pesar de la propaganda del $17 .^{\circ} \mathrm{sec}-$ tor de la AGLA encontrada en el lugar, lo clasificó como un delito común, puesto que se trataba de un asunto de rencillas personales: el vecino de Mosqueruela Cesario Vicente, huido y supuestamente unido a un grupo de guerrilleros, estaba enemistado con la asesinada por unas propiedades, lo que era conocido por la guardia civil, y a esta razón achacaron la muerte (a pesar de los carteles y la propaganda). Sin embargo, la guardia civil, incurriendo en una de sus frecuentes contradicciones, interrogó a varias personas de izquierdas a raíz de este suceso; aunque todos negaron su participación en los hechos, se detuvo a tres masoveros por «encubridores y auxilio de los bandoleros». ${ }^{253}$

Como vemos, en ambos casos la forma de actuar de la AGLA es diferente a la de Gúdar, acción cuya responsabilidad recayó directamente en Florencio Guillén y que la organización guerrillera nunca reivindicó. La propia propaganda interna de la AGLA emitió una muy débil condena de los hechos, a través de unas falsas declaraciones atribuidas al párroco de Valdelinares «que en ocasión de la operación de Gúdar donde se mató, junto a varios chivatos incluso a niños, se manifestó en la siguiente forma: Yo admito incluso que en la lucha que estos hombres llevan contra el régimen lleguen hasta la eliminación física de elementos que contra ellos actúan en

253 AHPT, sección Gobierno Civil, caja 1086, carpeta 71. La muerte de Ángela Gil aparece en el especial de Mundo Obrero dedicado a las acciones de la AGLA en 1947, pero allí se la denomina «el espía Ángel Gil», cambiando su identidad de mujer por una de hombre, quizá por la repulsa que producían, en general, los asesinatos de mujeres. 
delatores, lo que no está nada bien es que paguen inconscientes criaturas». Esta opinión no era, por supuesto, la del párroco de Valdelinares, sino la del guerrillero que elaboró el informe. Se trata de un curioso documento, por otro lado, que habla de supuestas declaraciones de sacerdotes defendiendo las acciones de los guerrilleros y condenando al régimen. Lo cierto es que, en general, el clero no estuvo nunca en el punto de mira de los guerrilleros, y en el único caso en el que un sacerdote recibió un anónimo se llegó a la conclusión de que se trataba de gente del pueblo con la que estaba enemistado. El guerrillero Ibáñez también insistía en la simpatía del clero, y añadía que incluso le ayudaba en ocasiones. Una posible interpretación de tal actitud es que los guerrilleros quisieran distanciarse de las actitudes anticlericales que la población identificaba con algunos de los hechos más luctuosos de la pasada guerra ocurridos en el bando republicano. $\mathrm{O}$ tal vez los guerrilleros comunistas eran conscientes de la sensibilidad religiosa de una parte de la población, principalmente de las mujeres, así como de la influencia que los párrocos podían ejercer desde sus púlpitos. Pero también eran conscientes, necesariamente, del apoyo que la Iglesia estaba dando al régimen, así como de su aprobación, tácita o explícita, de los métodos represivos franquistas. La actitud de los párrocos turolenses respecto a la guerrilla también resultaba ambigua, y no conocemos declaraciones suyas al respecto. Serán necesarias nuevas investigaciones que pongan de manifiesto la actitud de algunos sectores del clero, no de los que ocupaban altos cargos eclesiásticos sino aquellos que estaban más próximos al pueblo, que quizá en algunos casos sigan los patrones que presentan en Cataluña o el País Vasco, donde se ha detectado el apoyo de algunos párrocos a la oposición antifranquista ya en los años cuarenta. ${ }^{254}$

254 Los curas y la AGLA, en «Varios casos de curas que con su actitud y algunos [sic] han expresado su condena al régimen franquista y simpatía sobre el movimiento guerrillero y su actividad política». Archivo del Comité Central del PCE, sección Movimiento Guerrillero, jacquet 233. Informe de Ibáñez, en jacquet 1.

El párroco del anónimo es el de San Agustín. En el anónimo se leía: «Muy sr mío tengo entendido que en el llamado barranco ondo está el culpable de los Crímenes que se vienen cometiendo por esas latitudes en bien de España vusquelo. Un desconocido». Se organizó una batida en la estación de Rubielos, Albentosa y Barracas (Castellón), sin resultado. En cuanto al barranco Hondo, es una pequeña hondonada limpia de vegetación entre Albentosa y Barracas, no apta para ocultar a nadie. Dado que el cura no gozaba de gran simpatía en el pueblo, en particular por el alcalde, maestro y alguna gente joven, se deduce que el anónimo pudo ser "para darle miedo, pues él debe pasar a menudo por este barranco». Informe de 1/6/48, AHPT, sección Gobierno Civil, caja 1129, carpeta 116. 
Acciones como la de Gúdar no iban a quedar sin respuesta por parte de las fuerzas represivas, que incrementaron el grado de represalias entre la población civil. El 5 de octubre de 1947 se produjo una redada en varios pueblos de las proximidades (Aliaga y Montoro, entre otros), y varios vecinos de estas localidades fueron fusilados, sin someterlos a ningún tipo de proceso judicial, en los Altos de San Rafael (término municipal de Aliaga). En los documentos del PCE aparece la relación nominal de doce de estos campesinos, cinco de Aliaga y siete de Montoro, pero las fuentes orales indican que pudieron ser bastantes más. La ausencia total de documentación oficial sobre dichos asesinatos impide que podamos establecer con seguridad la relación entre esta represalia y los hechos de Gúdar, pero la proximidad de las fechas nos permite establecer esta hipótesis, hipótesis reforzada por las fuentes orales, concretamente por el testimonio de un miembro de una influyente familia derechista de Tronchón:

Una de las cosas que yo no comprendo, del pueblo de Montoro, cuando pasó lo de Gúdar, lo del pueblo de Gúdar, pues aquello fue diente por diente y cabeza por cabeza. Porque entonces el general Pizarro fue muy duro aquí en Teruel. Y tenían muchos de Montoro presos en Aliaga. Pasó lo de Gúdar y a las dos noches los otros presos de Montoro, a un barranco de Gúdar. Pues bueno, después, las familias de éstos que asesinaron de Montoro han ido a buscar las partidas de defunción y no las encontraban». ${ }^{25}$

El resto del año 1947 también fue extremadamente conflictivo. Se produjeron varias muertes, tanto por parte de los guerrilleros como de la guardia civil, y en los informes policiales se alude cada vez con más frecuencia a ciertas prácticas que ya se venían produciendo: la muerte de civiles relacionados con la guerrilla y la aplicación de la «ley de fugas». La nueva legislación, bajo el amparo del Decreto-Ley para la Represión del Bandidaje y el Terrorismo, permitía abiertamente este tipo de actuaciones (que tampoco antes se cuestionaban). En la segunda mitad del año 1947 se vivió una gran reactivación de las acciones represivas del régimen, y una verdadera ofensiva contra la guerrilla turolense, con el desplazamiento de numerosas tropas a la zona en conflicto, su declaración como «zona de

255 Relación de patriotas que han sido víctimas del aparato represivo civilero en la zona del 17 sector, Archivo del Comité Central del PCE, sección Movimiento Guerrillero. Entrevista, informante anónimo (hombre de sesenta y ocho años). Rubielos de Mora, 1 de agosto de 1999. Realizada en colaboración con José Giménez Corbatón. Entrevista, F.A. Cantavieja, 15 de julio de 1997. 
guerra» y toda una serie de medidas contra la población. Está claro que el general Pizarro era consciente de que la guerrilla había arraigado entre la población, y de que debía dirigir su ataque contra ésta si quería golpear mortalmente a aquélla. Conclusión a la que han llegado todos los regímenes que se han visto obligados a enfrentarse a movimientos guerrilleros que se desenvuelven en un medio rural.

A finales del año se detecta también un importante aumento de la conflictividad en las cuencas mineras, sobre todo en Utrillas y Martín del Río, y la colocación de varios artefactos explosivos en la vía del ferrocarril Zaragoza-Utrillas. Los asaltos a masías y coches de viajeros se multiplicaron, así como las bombas colocadas en las vías; incluso se llegaron a disparar ráfagas de metralleta al paso del tren. Las autoridades locales eran cada vez más reacias a dar parte y a luchar contra los guerrilleros, y el máximo responsable del orden en la provincia, el general Pizarro, era cada vez más inflexible. Muchas de estas autoridades fueron depuestas, e incluso el alcalde de Foz-Calanda, Julián Borraz, fue detenido y puesto a disposición del gobernador militar por no haber dado parte de la presencia de guerrilleros en dicha localidad hasta pasadas 24 horas, el plazo que había sido impuesto por los guerrilleros. ${ }^{256}$ Pero también aumentó la contraofensiva de las fuerzas represivas. El 18 de noviembre la guardia civil asaltó un campamento en el monte Camarracho, y cayó herido el entonces jefe del $17 .^{\circ}$ sector, el Valencia, que poco después moriría en el pueblo de Olba. ${ }^{257}$ Y la Guardia de Franco, junto con fuerzas del ejército, asaltó el 20 de diciembre otro campamento en el monte Rodeno (Valdecuenca). Allí se encontraban tres guerrilleros; uno de ellos, sin identificar, fue localizado y muerto. Resultó implicado también un vecino de Valdecuenca que les hacía llegar suministros y que logró huir. Pero la policía detuvo finalmente a once personas, en su mayoría de Valdecuenca, que actuaban de enlaces, muchos de ellos ugetistas y uno, Emilio García Murciano, antiguo alcalde del Frente Popular. Se registraron las cuevas de los alrededores y se halló una que servía de escuela, donde se incautaron de abundante material y documentación; se trataba del nuevo emplazamiento de la escuela de guerrilleros, que tuvo que ser trasladada de Agua-

256 AHPT, sección Gobierno Civil, caja 1085, carpeta 9, y caja 1130, carpeta 33.

257 AHPT, sección Gobierno Civil, caja 1130, carpeta 63. 
viva tras el incendio del pinar. ${ }^{258} \mathrm{El}$ año finalizó con el incendio del autovía Zaragoza-Tortosa en la estación de Valdeltormo por un grupo de unos diez guerrilleros. ${ }^{259}$

El año 1948 comenzó con la misma tónica que el anterior: alternando las acciones de los guerrilleros con las contraofensivas de la guardia civil. Lo más destacable es el incremento de detenciones a enlaces o encubridores de los guerrilleros: detenciones masivas de diez, quince individuos, que iban deteriorando seriamente las redes tejidas por los guerrilleros a lo largo de los años. Las organizaciones que habían logrado recomponerse trabajosamente fueron cayendo, como la Alianza Nacional de Bronchales, que se había creado en connivencia con los guerrilleros del $11 .^{\circ}$ sector de la AGLA y que desapareció en febrero de 1948 . Poco a poco, las deserciones iban también minando el movimiento guerrillero desde el interior; muchos de los guerrilleros que desertaban eran de ideología o, mejor dicho, de tradición anarquista, y no estaban de acuerdo con la ideología comunista que trataba de inculcárseles desde la dirección guerrillera. Algunos se entregaron y se pusieron al servicio de la guardia civil, como Jerónimo Barquero, miembro de la Alianza Nacional de Bronchales, que se unió a la guerrilla al ser detenido otro miembro de esta organización pero que sólo permaneció un mes con los guerrilleros, «por no poder sobrelle-

258 AHPT, sección Gobierno Civil, caja 1085, carpeta 13. Rodeno:

Relación nominal de los enlaces de los guerrilleros del campamento del monte

- Florentino Murciano Pradas (Valdecuenca).

— Emilio García Murciano (Valdecuenca). UGT, alcalde del Frente Popular.

- Manuel Soriano Villalba (Valdecuenca).

- Silvano Soriano García.

— José Alpuente Caballero (Saldón). Presidente de la UGT y luego del Comité.

— Ramón Almazán Soriano (Saldón). Antes de la guerra pertenecía a «las derechas».

— Felipe Alpuente Sánchez (Saldón). UGT, secretario del Comité.

- Bienvenido Jarque Martínez (Javaloyas). Principal organizador de la red de enlaces de la comarca, Izquierda Republicana.

- Tomás Jarque Aspa (Javaloyas).

- Hilario Sánchez Lázaro (Saldón). Secretario de la tesorería de la CNT, parte del Comité y jefe de abastecimientos.

Algunos de estos enlaces huirán al campamento al ser detenida una mujer que actuaba de enlace, pero los guerrilleros les ordenaron volver a sus casas. (AHPT, sección Gobierno Civil, caja 1130, carpeta 70.)

259 AHPT, sección Gobierno Civil, caja 1085, carpeta 19. 
var la vida que les imponían por ser de sentimientos diferentes a los que pretendían inculcarle», como afirmó al entregarse a la guardia civil en la Comandancia de Teruel. ${ }^{260}$ Otros huyeron a Francia, ya que no podían seguir en la guerrilla a causa de estas diferencias ideológicas y tampoco reinsertarse en la vida civil. Un campesino de Cañada de Benatanduz cuenta cómo dos guerrilleros de Cañada, anarquistas, decidieron irse a Francia, y al pasar por su casa a despedirse le explicaron las razones que les llevaban a abandonar la guerrilla: «[...] y ya, le dijo a mi padre: decidimos de marcharnos, porque aquí si los unos eran de la CNT los otros eran de otra cosa, y pasó como cuando la guerra, como cuando se empezaron a pegar entre ellos... pasó un caso así entre los maquis: los peores servicios se los mandaban a éstos, los de la CNT [...]». ${ }^{261}$

También las acciones guerrilleras participaron de la escalada de terror del año 1948. En febrero fueron asesinados el alcalde de El Cuervo y su esposa. ${ }^{262}$ También este mes se produjo el asalto al coche de viajeros de la línea Alcorisa-Cantavieja, conocido como el Caimán, a la altura del barranco de los Degollados; tras un breve tiroteo con los guardias de la escolta, que se ocultaron en una alcantarilla junto a la carretera, los guerrilleros hicieron bajar a los viajeros e incendiaron el autobús. En ese momento, apareció un coche ocupado por Antonio Pérez Escorihuela (teniente de alcalde de Villarluengo y persona destacada en la zona por su "adhesión a la causa nacional») y por el practicante del pueblo, Antonio Conesa. Los guerrilleros les obligaron a detenerse y huyeron por el barranco llevándose con ellos a Antonio Pérez. Éste fue encontrado al día siguiente, gravemente herido: había sobrevivido a su propio fusilamiento (e incluso al tiro de gracia). ${ }^{263}$ Apenas un mes después de estos acontecimientos, la provincia recibía la visita del ministro de Trabajo y de José Moreno Torres, director general de Regiones Devastadas, a la capital y zonas mineras. Una visita que pretendía transmitir a la población una sensación de normalidad, y sobre todo de impunidad: las autoridades franquistas podían visitar una provincia en estado de

260 AHPT, sección Gobierno Civil, caja 1129, carpeta 103.

261 Entrevista, informante anónimo (hombre de sesenta y ocho años). Rubielos de Mora, 1 de agosto de 1999. Realizada en colaboración con José Giménez Corbatón.

262 AHPT, sección Gobierno Civil, caja 1130, carpeta 43.

263 AHPT, sección Gobierno Civil, caja 1130, carpeta 39. 
guerra, en alerta permanente, a pesar de la amenaza de la acción guerrillera. Podían hablar de reconstrucción, de creación de puestos de trabajo, de fin del paro obrero y de reactivación de la economía, mientras los guerrilleros hacían saltar trenes y la guardia civil detenía campesinos por docenas. $^{264}$

En mayo, la Agrupación sufrió un serio revés: el asalto a un campamento en Salinas de Valtablao, en el que murieron el jefe del 5..$^{\circ}$ sector, conocido como Medina, Tito o Gil; el subjefe, Ramón; y el jefe político, Cástor Plaza Soriano, Berta. El campamento se localizó gracias a «los servicios del bandolero Manuel López Rodríguez», que se había unido a la guerrilla en octubre de 1947, y que se presentó a la guardia civil tras «gestiones practicadas al lado de familiares del bandolero». Esta expresión del informe delata una más que posible coacción, razón a la que quizá se deban achacar algunas de las deserciones de guerrilleros naturales de la zona, cuyas familias quedaban expuestas a las "gestiones» de la guardia civil. ${ }^{265}$ Más grave fue el desmantelamiento de la red de colaboradores de las masías del Carmen, en Mosqueruela, que tuvo lugar en mayo de 1948, y en el curso del cual varios moradores de las masías fueron detenidos por «enlaces y encubridores de bandoleros». Sin embargo, estas detenciones no significaron el fin de la red de apoyo de Mosqueruela; durante el resto del año 1948 se siguieron efectuando detenciones, y el mes de diciembre se descubrieron los restos de un campamento de los guerrilleros en terrenos del masico Manuela, campamento que incluía hasta un matadero clandestino de reses. ${ }^{266}$

Pero, sobre todo, la gran pérdida que sufrió la AGLA en el mes de mayo de 1948 fue la de su jefe más carismático, Ángel Fuertes Vidosa, Antonio, que cayó en un encuentro con la guardia civil en la masía Guimerá, en Castellón. Junto a él murió el guerrillero Deseado, responsable de la publicación de El Guerrillero. La muerte de Antonio permanece rodeada de un halo mítico; se cuenta que antes de morir destruyó los

264 Jefatura Provincial de Teruel, informes mensuales, mayo de 1948, AGA, sección Presidencia, DNP, caja 183.

265 AHPT, sección Gobierno Civil, caja 1129, carpeta 127.

266 Las detenciones de Mosqueruela, en AHPT, sección Gobierno Civil, caja 1130, carpeta 2. El descubrimiento del campamento, en AHPT, sección Gobierno Civil, caja 1129 , carpeta 75 . 
documentos que llevaba borrándolos con su propia sangre. Tras su muerte, Antonio fue rápidamente sustituido por Pelegrín Pérez, Ricardo, responsable del Comité Regional del partido en Valencia. Como el primer jefe de la Agrupación, Andrés, Pelegrín Pérez era natural de Buñol (Valencia), comenzó su militancia política en la CNT, de la que salió en 1935 para ingresar en la UGT, y durante la guerra civil había sido comisario político del XIV Cuerpo de Ejército de Guerrilleros, que posteriormente daría nombre a la primera agrupación de guerrilleros que se formó en Francia durante la segunda guerra mundial. En el curso de ésta, Pelegrín Pérez estaba en la URSS, como voluntario del Ejército Rojo, tras su paso por una escuela política, en la que permaneció de 1939 a 1941. Tras su participación en la guerra encuadrado en el ejército soviético, Pelegrín Pérez fue llamado de nuevo a Francia, y enviado a Valencia como reponsable político del PCE. ${ }^{267}$ Una vez muerto Antonio, Ricardo ocupó el puesto de jefe de la Agrupación por indicación de los dirigentes del partido, en un momento en que el Estado Mayor, encabezado por Pepito, sólo tenía contacto con el $11 .^{\circ}$ y el $5 .^{\circ}$ sector. Se mandaron enlaces a los sectores $17 .^{\circ}$, mandado por Manso, y $23 .^{\circ}$, al frente del cual estaba Carlos, en los que Antonio aún era considerado como jefe de la Agrupación, pues se desconocían los últimos acontecimientos.

Ricardo llegó a la guerrilla con numerosos planes acerca de los cambios que deseaba llevar a cabo en la Agrupación, y que, en realidad, transformaban sustancialmente su funcionamiento. Por ejemplo, quería conocer personalmente a todos los guerrilleros, acercar la guerrilla a los centros industriales y reducir las acciones llamadas «de justicia» (ejecuciones y venganzas), realizando tan sólo las que fueran muy populares. En conjunto, se trataba de dar más importancia al trabajo político: la eterna aspiración de los dirigentes más politizados y «conscientes» del PCE con respecto a la guerrilla.

Pero Ricardo permaneció poco tiempo en la AGLA. El 19 de agosto de 1948 murió en algún lugar entre La Ginebrosa y Aguaviva; se cree que a causa de las heridas sufridas en un choque con la guardia civil. Lo encon-

267 Autobiografía de Pelegrín Pérez Galarza. Archivo del Comité Central del PCE, sección Movimiento Guerrillero, Equipo de pasos, informes sobre camaradas, sign. 956. 
tró muerto un campesino entre Mas de las Matas y Seno el 20 de agosto, un día después. Su muerte se produjo en circunstancias muy extrañas: al parecer, iba en un viaje de reconocimiento con otros guerrilleros, que tras el ataque lo dejaron abandonado. Al menos, ésa es la acusacion que realizó el guerrillero Manso cuando informó a la dirección del partido acerca de la muerte de Ricardo. Un labriego y su hijo, de Aguaviva, también habían visto el cadáver de Ricardo, pero no se atrevieron a notificarlo a las autoridades, puesto que el padre tenía antecedentes izquierdistas y acababa de salir de la cárcel. El miedo y la represión eran tan grandes que, ante un hecho como éste, la población no sabía cómo debía actuar. La violencia y la anormalidad de la situación eran tan extraordinarias que no existía un comportamiento "correcto» que garantizase la seguridad. En la imagen del encuentro entre los campesinos y el guerrillero muerto se condensa, en cierto modo, el ambiente vivido en estos años por ese sector de la población campesina izquierdista, aterrada y represaliada, que simplemente trataba de sobrevivir, sin saber muy bien cuál era la forma de conseguirlo.

La muerte de Ricardo coincidió en el tiempo con la famosa reunión que los dirigentes del PCE mantuvieron en Moscú con Stalin en agosto de 1948, y de la que al parecer surgió el famoso "cambio de táctica» respecto a la lucha guerrillera, que consistiría en transformar a las agrupaciones guerrilleras en organismos políticos y en iniciar una penetración en los sindicatos verticales, es decir, combinar la acción de las organizaciones clandestinas con la utilización de las organizaciones legales del régimen franquista. Los planes de Ricardo para la AGLA iban en esta dirección, y pensaba dar preferencia a la vida política de la Agrupación frente a las acciones armadas. Pero la muerte le impidió poner en práctica la nueva política. Una vez más, la AGLA y el PCE perdían a un hombre de gran preparación política y militar, que parecía saber cómo encauzar la guerrilla para atajar sus problemas internos. Tras su desaparición, los planes de modernización y politización de la guerrilla nunca iban a llevarse a cabo. Es más, con esta muerte parece abrirse en la AGLA una lucha por el poder; los conflictos entre comunistas "ortodoxos» y anarquistas (o considerados como tales), que habían permanecido en un estado más o menos latente, se agudizaron y se inició un período de "depuraciones» y asesinatos en el interior mismo de la guerrilla. La organización guerrillera quedó duramente afectada, circunstancia que no pasó desapercibida a las autoridades 
franquistas, que afirmaban en diciembre de 1948 que «se ha conseguido la extirpación puede decirse total de los bandoleros» y que, respecto a las actividades clandestinas de tipo político, la tranquilidad «es absoluta». La apreciación era optimista, pero las autoridades intuían que comenzaban a ganar la partida. ${ }^{268}$

\subsubsection{Decadencia y fin de la guerrilla en Aragón (1949-1952)}

La victoria más aplastante de Franco fue morir en la cama. Ni uno solo de los proyectos de la oposición y ni una sola de sus esperanzas se cumplieron en vida de él. Para el general Franco, su veinte de noviembre fue su uno de abril.

(Eliseo Bayo, Los atentados contra Franco)

\section{El declive de la AGLA}

A partir de la muerte de Pelegrín Pérez, Ricardo, las cosas habían ido de mal en peor en la Agrupación, y la desconfianza y la desmoralización se habían apoderado de los guerrilleros. Los problemas generados por la presencia de cenetistas en las filas guerrilleras y las divergencias entre éstos y la dirección comunista pasaron a primer plano, y dio comienzo una etapa de depuraciones y de terror. Las depuraciones no eran nuevas en el seno de la Agrupación; ya hemos visto algunos casos en los que un "provocador»o un desertor eran eliminados para evitar males mayores. Pero en estos momentos de crisis, las sospechas y las acusaciones de provocación o traición se extendieron de forma indiscriminada.

A esto se unió el efecto que la represión estaba teniendo sobre la población campesina. Desde principios de 1947, más exactamente desde que el general Pizarro tomó a su cargo la tarea de acabar con la guerrilla, la población estaba sufriendo las consecuencias de una fortísima represión encaminada a minar los apoyos de la guerrilla, cosa que se consiguió, sobre todo, aterrorizando a los pobladores de la zona con redadas multitudina-

268 Informe de Manso sobre Ricardo, Archivo del Comité Central del PCE, sección Movimiento Guerrillero, Equipo de pasos, informes sobre camaradas, sign. 639. Memoria de la Comandancia de la Guardia Civil de Teruel (1966). Centro de Estudios Históricos de la Guardia Civil, Dirección General de la Guardia Civil. Jefatura provincial de Teruel; informes mensuales. AGA, sección Presidencia, DNP, caja 183. 
rias, palizas, torturas, aplicación de la «ley de fugas» e incluso ejecuciones sumarias, sin pasar por un juicio previo. ${ }^{269}$ El desalojo de las masías a partir de agosto de 1947, con la obligación de pernoctar en los núcleos de población, había trastocado la cotidianeidad campesina. Las "contrapartidas", grupos de guardias civiles disfrazados de guerrilleros y que actuaban como tales con objeto de desenmascarar a los colaboradores de la guerrilla, aterrorizaban a los campesinos con una actuación indiscriminada. La vigilancia aumentó en los pueblos, para evitar que los guerrilleros encontrasen refugio en las casas de sus simpatizantes. Las familias de tradición izquierdista sufrían un acoso constante, que llegó al extremo cuando los guardias recibieron órdenes de la jefatura de entrar en sus casas para efectuar registros a diferentes horas de la noche. Esto hacía que la gente viviese en un constante estado de alarma y sobresalto. Y, evidentemente, también limitó mucho las posibilidades de los guerrilleros de ocultarse o abastecerse. ${ }^{270}$ Los propios guerrilleros comenzaron a inspirar más temor que admiración a la población, pues, al incrementarse la represión, aumentaron también las denuncias y chivatazos y, por lo tanto, las venganzas de los guerrilleros. Era precisamente esta situación de escalada de terror la que pretendía paliar Ricardo, pero su muerte repentina no le permitió siquiera dejar sentadas las bases de una nueva política guerrillera con respecto al campesinado.

En cuanto a las acciones guerrilleras, la operatividad de la guerrilla disminuyó drásticamente. Los campamentos empezaron a ser abandonados con precipitación, se produjeron numerosas deserciones y menudearon los encuentros entre guerrilleros y grupos de la guardia civil, en los cuales aquéllos salían cada vez peor parados. Algunos guerrilleros cayeron en manos de las fuerzas represivas, que iban así reuniendo más datos sobre la composición y el emplazamiento de los grupos guerrilleros. Todos estos elementos se combinaron en un encuentro con la guardia civil en la Puebla de Benifasar, en febrero de 1949, en el que tres guerrilleros fueron cercados en una masía por fuerzas de la guardia civil. Uno de ellos murió en el tiroteo, otro se suicidó al verse malherido y el tercero se entregó. Este último era Eduar-

269 Acciones que eran facilitadas por la promulgación del Decreto-Ley para la Represión del Bandidaje y el Terrorismo, de la que hablaremos más extensamente en el capítulo dedicado a la represión.

270 AHPT, sección Gobierno Civil, caja 1086, carpeta 102. 
do Hernández Ruiz, el Enrique y tío Pito, del grupo de Carlos. En el informe se relata que, al ser interrogado, «insistía en el absurdo de que había llegado de Francia, que pertenecía al partido recientemente creado allí llamado demócrata de derechas que dirigía Prieto y que había venido con tres más al objeto de sembrar el derrotismo entre los bandoleros comunistas de los que es enemigo y así otras cosas a todas luces inverosímiles, hasta que tras un duro interrogatorio [...]» confesó que estaba en la guerrilla desde mediados de 1944. Tras expresiones como «duro interrogatorio» se ocultan en los informes las torturas a las que eran sometidos los guerrilleros que caían en las manos de las fuerzas represivas, y que les hacían delatar a sus compañeros y delatarse a sí mismos. ${ }^{271}$

Enrique fue enviado a Morella y posteriormente a Valencia, donde hemos perdido su pista. Pero en aquellos momentos, en la mayoría de los casos, no se hacían prisioneros entre los guerrilleros: cuando los guardias capturaban a uno, le hacían confesar in situ y después lo ejecutaban. A no ser, como en el caso de Domingo Sánchez, Vilches, que el guerrillero se prestase a "colaborar con la fuerza», si bien le sirvió de poco su voluntad de colaboración: capturado el 20 de marzo de 1949, murió pocos días después, en un encuentro entre el grupo de guardias a los que acompañaba y guerrilleros. No sabemos cómo murió, si abatido por sus antiguos compañeros o por fuerzas de la guardia civil, que temieron que se arrepintiera de su decisión o que los traicionara. En todo caso, hay que resaltar que pocos de los guerrilleros «entregados» sobrevivieron mucho tiempo; los que superaron la etapa de su estancia en el monte colaborando con las fuerzas represivas fueron entregados a las autoridades militares, que en la mayoría de los casos les aplicaban la última pena. Era la última etapa de la represión contra los guerrilleros: la aplicación de la pena de muerte. Pero la mayoría de ellos ni siquiera llegaron a verse frente a un tribunal. Y lo mismo ocurrió a muchos civiles, acusados de «colaboración con bandoleros». ${ }^{272}$

\section{AHPT, sección Gobierno Civil, caja 1086, carpeta 120.}

272 Memoria de la Comandancia de la Guardia Civil de Teruel (1966). Centro de Estudios históricos de la Guardia Civil, Dirección General de la Guardia Civil. Entre estos casos de colaboración entre guerrilleros entregados y guardia civil hay uno especialmente dramático, el de Isaías Jiménez, Manolo y Maqui, que se saldó con la muerte de varios guardias, de una joven que habitaba en la masía donde se alojaban el retén y el guerrillero y la del propio guerrillero. Se recoge en Mercedes Yusta, La guerra de los vencidos..., op. cit., pp. 150-151. 
Como muestra de represión despiadada puede citarse la acción desplegada a raíz de un doble asesinato cometido en Dos Torres de Mercader en agosto de 1949, que costó la vida a cinco personas de la localidad, que fueron detenidas y a las que se aplicó la «ley de fugas» después de que confesaran, bajo torturas, su relación con los guerrilleros Francisco y Miguel Serrano Iranzo, a los que se imputaba el doble asesinato. ${ }^{273}$ En el caso del conocido como "crimen de Dos Torres» estamos, probablemente, ante una acción de ajusticiamiento, como lo fue la muerte del padre del jefe local de Falange de Montoro de Mezquita, José Fandos Izquierdo, secuestrado el 3 de marzo mientras transportaba por la carretera de Cantavieja, junto con otros dos individuos, víveres que les habían sido requisados a los guerrilleros. ${ }^{274}$

Finalmente, varios meses después de la muerte de Ricardo, en marzo de 1949, el Estado Mayor de la Agrupación decidió enviar a Francia una delegación de la AGLA para informar de la situación y de las dificultades que estaba atravesando. Dicha delegación estaba encabezada por Francisco Bas Aguado, Pedro, jefe político de la Agrupación, y se componía además de Agapito Esteban Mínguez, Mateo, jefe del Servicio de Información de la AGLA, Doroteo Ibáñez, Manuel Gracia Jarque, Lorenzo, y Manuel Pérez Cubero, Rubio. ${ }^{275}$ El día 7 de marzo, poco después de organizarse su marcha, tuvo lugar un «servicio coordinado» de fuerzas (que consistía en una amplia operación policial que combinaba fuerzas del ejército y la guardia civil), en el curso del cual los guerrilleros fueron atacados mientras descansaban en un campamento de la partida del Tamborero, en Mosqueruela, y Mateo resultó muerto. Además de encontrar armas, 1300 hojas de propaganda y folletos pequeños y 75 números de Mundo Obrero, los atacantes se incautaron de dos cartas que Mateo llevaba encima. Una estaba firmada por Pedro y contenía la relación de bajas sufridas por los guerrilleros, con sus nombres reales y de guerra, y la otra estaba firmada por Manso e iba dirigida al Estado Mayor. En ella comunicaba que "[...] de dinero estamos a pré [sic], pero si levanta el tiempo, ya que hay bastante nieve, lo solucionaremos", y que durante el invierno empleaban el tiempo

\footnotetext{
273 AHPT, sección Gobierno Civil, caja 1086, carpetas 12 y 84.

274 AHPT, sección Gobierno Civil, caja 1086, carpeta 112.

275 Reunión de la AGLA, apuntes de Santiago, sign. 624-625. Archivo del Comité Central del PCE, sección Movimiento Guerrillero, Equipo de pasos, informes sobre camaradas.
} 
en la capacitación política y cultural. Según Manso, la moral de los guerrilleros era excelente, y ardían en deseos de que pasara lo más crudo del invierno para "pegar a los tricornios». La carta revela un fuerte componente de idealismo, que explica que estos hombres continuasen en el monte a pesar de la represión cada vez más acuciante y el aislamiento cada vez mayor a los que estaban sometidos. Quizá el mismo aislamiento les proporcionaba las condiciones necesarias para seguir alimentando una esperanza que el desmoronamiento de las redes de apoyo entre la población y de la propia estructura de la guerrilla desmentía continuamente. El hecho de que la carta jamás llegase a su destino es todo un símbolo de este desmoronamiento, que sólo la ilusión y el idealismo de algunos hombres conseguía frenar en parte. ${ }^{276}$

El resto de los guerrilleros consiguió su objetivo; llegaron a Francia y se entrevistaron con Santiago Carrillo, cada uno por separado, para darle su impresión de la situación que estaba atravesando la Agrupación. Todos coincidían en que en el seno de la Agrupación había un estado de terror, provocado por Carlos, entre otros, y dirigido contra gente de la CNT y "provocadores». Refiriéndose a las deserciones, el guerrillero Pedro afirmaba: "Algunos hombres dejaban escrito: "Nos vamos porque tenemos miedo a vuestras balas" [...]"; "se mató a hombres en la cama [...]»; «se marcharon gentes de la CNT porque no se ha sabido tratar a la gente [...]»; "Carlos [Jesús Caellas, que, paradójicamente, procedía de las Juventudes Libertarias] amenazaba con la pistola [...]»; "por culpa de Carlos hubo dos deserciones y se mató a dos. Se les acusaba de cosas no ciertas $[\ldots] »$.

Otra cosa en la que coincidían era la situación positiva del $11 .^{\circ}$ sector en comparación con el resto; era el mejor organizado y el menos problemático, méritos que se atribuían a su jefe, Grande, a pesar de que Pedro también comentaba acerca de él que era «un poco alegre, no estudia las cosas», lo cual no le impedía desarrollar una gran actividad y ser muy querido por sus hombres (y, también, que en su sector sí existiese la tan traída y llevada «vida de Partido»). Igualmente, se puso sobre la mesa el espinoso tema de la relación entre la Agrupación guerrillera y el partido; claramente, se estaba primando a la primera sobre el segundo. Los guerrilleros

276 AHPT, sección Gobierno Civil, caja 1086, carpeta 113. 
mencionaban que «no se estaba organizando el Partido», que «no habían comprendido bien el papel del Partido en la Agrupación»... A nuestro entender, esto es muy significativo, así como la preferencia de los guerrilleros por editar El Guerrillero, que era el periódico de la Agrupación, antes que Mundo Obrero, o el comentario acerca de que los campesinos manifestaban «resistencia a organizarse» (lo cual significaba, básicamente, resistirse a militar en el PCE).

La labor de reclutamiento político había fracasado en el agro turolense. Lo cual no quiere decir, en absoluto, que los campesinos no colaborasen con la guerrilla. Al contrario. El elevado número de detenciones, así como las medidas que las fuerzas represivas se vieron obligadas a tomar contra la población, revelan que la guerrilla encontró un fuerte apoyo entre los campesinos y campesinas turolenses. Pero las razones de este apoyo poco o nada tenían que ver con la militancia comunista o con un ideario político más o menos abstracto. Se trataba de un apoyo genérico a la causa antifranquista en aquello en lo que se identificaban con ésta: lucha contra las fuerzas represivas, contra la opresión del régimen, contra los que habían ganado la guerra civil y estaban en el poder. Contra los que metían en la cárcel, torturaban, asesinaban, se llevaban una gran parte de la cosecha, desalojaban las masías, pagaban salarios de hambre...; todo esto tiene poco que ver con la conciencia política como la entendían los mandos comunistas en Francia, pero era algo que los guerrilleros, muchos de los cuales procedían de aquel medio campesino, entendían muy bien. Aquí observamos la contraposición de dos tradiciones culturales diferentes: la de las comunidades campesinas, con un sistema de pensamiento "concreto y alegórico», en expresión de Javier Ugarte, y la de los ideólogos comunistas, con un pensamiento abstracto. En tal sentido, el discurso de los guerrilleros también había evolucionado; de una primera etapa más plural y abierta, bajo el mando de un hombre como Antonio, que comprendía la idiosincrasia del campesinado, se pasó a partir de 1948 a una etapa más dura, controlada por los comisarios políticos que el PCE iba enviando para encabezar la Agrupación y que conllevó un deterioro de las relaciones internas en el seno de la guerrilla. En esta segunda etapa comenzaron a desgajarse individuos menos ideologizados (en el sentido "comunista» de la expresión) que desertaban o se dedicaban a realizar por su cuenta acciones que cada vez presentaban un carácter más próximo a la delincuencia, como ocurriría en el caso de algunos guerrilleros del $17 .^{\circ}$ sector. 
El resultado del encuentro con Carrillo fue que los guerrilleros recibieron la orden de poner la labor política por delante de la lucha armada, y la consigna de ser «instructores políticos y organizadores del campesinado» ${ }^{277}$ (cosa que debió desconcertarles bastante, pues ya llevaban muchos años realizando lo que ellos suponían que era una labor política y de organización del campesinado). Se diría que se produjo cierta rivalidad entre la dirección y la organización guerrillera, y la primera decidió tomar las riendas y reconducir una situación que se estaba volviendo incontrolable. Un símbolo de esto es que otra de las órdenes recibidas fue dejar de editar El Guerrillero y distribuir sólo Mundo Obrero. La dirección en Francia no volvió a designar ningún jefe para la AGLA tras la muerte de Ricardo, sino que pretendió transformar la Agrupación en un organismo de carácter político, como había intentado Ricardo, que estaba en la línea del famoso "cambio de táctica" de la guerrilla que Stalin aconsejó llevar a cabo a los miembros del Buró Político en Moscú a partir de 1948, y que realmente nunca se llegó a poner en práctica en la forma en que había sido concebido por los dirigentes comunistas.

Según los planes de éstos, la Agrupación pasaría a ser un órgano de resistencia con la finalidad de recomponer el PCE en las poblaciones, y para tal fin se designó un Comité Regional de Resistencia en Levante. Como secretario general, el PCE envió a un tal Andrés, y Florián García, jefe del $11 .^{\circ}$ sector, fue designado secretario de propaganda. Andrés llegó de Francia guiado por Francisco Bas Aguado, Pedro, con un grupo de otros once guerrilleros enviados desde Francia, ninguno de los cuales tenía experiencia de la situación que estaba viviendo la AGLA, enfrentada a una represión cada vez más dura. Este grupo componía el Comité Regional de Levante, que estableció su campamento en el Rincón de Ademuz (Valencia), en un lugar llamado Cerro Moreno, cerca de la localidad de Santa Cruz de Moya. El 7 de noviembre de 1949 sufrieron un ataque sorpresa de la guardia civil y fueron aniquilados. De la matanza sólo se salvó el guerrillero Pedro, que había acompañado al Comité y debía enlazarlo con los grupos guerrilleros; una vez más, la guardia civil no hizo prisioneros. ${ }^{278}$ Ésta fue la mayor catástrofe vivida por la Agrupación en toda su historia,

277 Fernanda Romeu, Más allá..., op. cit., p. 164.

278 Ib. 
y es una muestra de hasta qué punto era incapaz de proteger a sus propios cuadros dirigentes de la represión. El Servicio de Información de la Guardia Civil (SIGC) logró identificar a cinco de los guerrilleros muertos: se trataba de Ramírez, José Cavero de la Cruz, Eulogio, Constantino Emiliano Ruiz y Manolo. Militantes sin antecedentes en los archivos policiales, «limpios», recién llegados desde Francia para encontrar la muerte en Cerro Moreno. ${ }^{279}$

A partir de entonces la situación se hizo cada vez más difícil para los guerrilleros; de hecho, se puede decir que la matanza del 7 de noviembre marca la descomposición de la AGLA. Sin cabeza visible, jefe ni objetivos precisos, cada sector quedó, en cierto modo, abandonado a sí mismo y a las órdenes únicamente de su jefe de sector. Los grupos de guerrilleros comenzaron a realizar acciones independientes, sin seguir directrices comunes, excepto el grupo de Grande, el $11 .^{\circ}$ sector, que, al parecer, mantuvo hasta el último momento su estructura como sector de la AGLA así como los intentos de realizar vida política. De este modo, el grupo mandado por Francisco Serrano, el Rubio, que teóricamente formaba parte del $17 .^{\circ}$ sector, se fue apartando cada vez más de la línea política marcada por el PCE. De todas formas, éste fue siempre un sector muy marcado por la pertenencia a la zona de sus guerrilleros, y muy ligado, por tanto, a la conflictividad local. Cuando en marzo de 1949 los guerrilleros del Rubio mataron a Juan Manuel Chillida, guardia jurado de Castellote y conocido por los habitantes de la zona como el Cabrito, estaban efectuando una acción guerrillera y, a la vez, un acto de justicia popular contra un personaje fuertemente odiado por una parte de la población. ${ }^{280}$

Los acontecimientos que se desarrollaban en este sector estaban determinados por la interacción de la guerrilla, la población y las fuerzas represivas. Las acciones de la guerrilla provocaban reacciones de gran magnitud entre las fuerzas represivas, que muchas veces se dirigían contra la población; las relaciones que existían entre los guerrilleros y los pobladores de la zona, unidos por redes de parentesco o amistad que se traducían en redes de colaboración, hacían que los guerrilleros reaccionasen violentamente

279 Memoria de la Comandancia de la Guardia Civil de Teruel (1966). Centro de Estudios Históricos de la Guardia Civil, Dirección General de la Guardia Civil.

280 AHPT, sección Gobierno Civil, caja 1086, carpeta 107. 
frente a estas acciones represivas. Pero un sector de la población civil se implicó también en la represión colaborando con la guardia civil y delatando a los guerrilleros o sus colaboradores; contra este segmento de población se dirigieron también las acciones de la guerrilla. Por lo tanto, se produjo una ola de violencia que iba de unos grupos a otros, y que implicaba a la población que se comprometía con una u otra de las facciones, con los guerrilleros o con la guardia civil.

Durante la etapa comprendida entre los años 1949 y 1950 fueron frecuentes las caídas de guerrilleros y de enlaces, de forma que los grupos actuaban cada vez más aislados unos de otros, y la desconfianza hacia la población iba en aumento. Había pasado para siempre la época en la que los guerrilleros podían llamar casi a cualquier puerta, con la esperanza de ser atendidos o al menos recibidos por los moradores de las masías. Ante la gravedad de la situación, la dirección en Francia envió a un delegado, José Gros, cuya misión, mantenida en secreto, era retirar definitivamente la guerrilla. Gros había sido guerrillero en la URSS durante la segunda guerra mundial, de 1942 a 1945, y en Aragón y Cataluña de 1946 a 1951. Sin embargo, poco sabemos de él hasta el momento en que embarcó en Marsella, en el año 1950, junto con Ibáñez, Adelino Pérez Salvat, Teo, y otros guerrilleros con experiencia en la URSS, en Francia o en la propia AGLA, rumbo a las costas levantinas. El grupo desembarcó en Alcanar, entre San Carlos de la Rápita y Vinaroz, y se puso en contacto con lo que quedaba de la Agrupación.

Y en la Agrupación quedaban, sobre todo, guerrilleros incorporados a los grupos del monte desde sus lugares de origen, profundamente conectados con la problemática local y poco sensibles a las directrices políticas que trataba de comunicarles la delegación enviada desde Francia. José Gros, en su libro de memorias, se queja del ambiente que encontró a su llegada a la Agrupación, fundamentalmente del escaso trabajo político, que según él llevaba a los guerrilleros a la indiferencia y al fatalismo. Desde nuestro punto de vista, tal estado de ánimo era perfectamente comprensible si tenemos en cuenta las enormes dificultades que atravesaba la Agrupación, debidas sobre todo a la represión, pero también a los problemas internos que ya hemos descrito. El objetivo político, efectivamente, se estaba perdiendo; y una consecuencia de esto era que los grupos de guerrilleros sólo luchaban ya por su propia supervivencia. Para Gros, esto implicaba un grave problema: que el guerrillero se convirtiese en un bandolero, confirmando así la acusación del régimen contra los grupos arma- 
dos. De ahí la necesidad, casi psicológica, de que la guerrilla estuviese en contacto con el partido, de recibir orientaciones para sentirse parte de un proyecto político. ${ }^{281}$

Desde la óptica de Gros y de los enviados de Francia, era preciso acabar para siempre con actuaciones tan alejadas de la tradicional actuación de la guerrilla como el secuestro de un grupo de jóvenes veraneantes, cinco chicos y nueve chicas, llevado a cabo el verano de 1951 en Alcalá de la Selva por cuatro guerrilleros entre los que se encontraban Florencio Guillén, el Viejo y Manuel Pérez Cubero, el Rubio. Ciertamente, los tiempos estaban cambiando fuera de la guerrilla, en el «mundo exterior»: unos años antes, la presencia de un grupo de jóvenes excursionistas urbanos en aquellas sierras hubiera sido impensable. Ello prueba, por un lado, que la alarma social con respecto a la guerrilla había disminuido enormemente, y por otro, el profundo desconocimiento que fuera de la zona afectada se tenía del problema de la guerrilla, debido a la campaña de desinformación mantenida por el régimen, que no permitió que la prensa filtrara las acciones de la guerrilla o de sus represores. La actitud de los guerrilleros también había cambiado; dejaron marchar a la mayoría de los rehenes ante las súplicas de éstos, y retuvieron sólo a dos chicos hasta que obtuvieron el rescate exigido: 47000 pts. El secuestro de Alcalá de la Selva, como aparece narrado en las fuentes policiales, con su ausencia total de motivaciones políticas y ese cierto «enternecimiento» de los viejos guerrilleros, que aceptan dejar marchar a la mayoría de los jóvenes y transmiten una imagen muy alejada de la del bandolero sanguinario y endurecido por los largos años de permanencia en el monte, desprende un aroma crepuscular. Pero, al parecer, José Gros y el resto de enviados por el partido no compartían esta visión poética. ${ }^{282}$

Sin embargo, es injusto acusar de esta situación a los propios guerrilleros. La dirección en Francia había impulsado durante demasiado tiempo políticas irrealizables, había escatimado los recursos destinados a la guerrilla y, sobre todo, había alargado demasiado una situación que ya no tenía salida. En el momento en que la guerrilla empezó a ser acosada por

281 José Gros, Abriendo camino. Relato de un guerrillero comunista. Librairie du Globe, París, 1971.

282 AHPT, sección Gobierno Civil, caja 1031, carpeta 7. 
la represión y fue perdiendo los apoyos de la población, la lucha se convirtió en una tarea solitaria. Fracasado el intento de convertir a los guerrilleros en punta de lanza de una insurrección popular, y frente a la insensiblidad mostrada por las potencias occidentales, el objetivo de la guerrilla no tenía posibilidades de éxito. Se había conseguido producir un efecto de desestabilización del régimen, pero el precio pagado era ya demasiado alto. En la guerrilla estaban muriendo los mejores hombres del PCE, los más preparados política y militarmente, y la represión antiguerrillera estaba arrastrando consigo a las redes de resistencia que implicaban a un importante sector de la población civil, a los izquierdistas más activos y concienciados. La guerrilla debería haberse convertido en un ejército popular, en el sostén de la reconstrucción de las organizaciones izquierdistas. Pero la represión era demasiado poderosa, y las condiciones demasiado duras. Por tanto, la única salida era retirar la guerrilla y renunciar al objetivo de convertirla en un instrumento de lucha política. El PCE lo comprendió demasiado tarde.

Los últimos tiempos de la guerrilla levantina son oscuros. Realmente, parece que el responsable de la evacuación de los guerrilleros a Francia a principios de 1952 fue el propio Grande, que reunió a sus hombres del 11. ${ }^{\circ}$ sector y a algunos de los sectores $5 .^{\circ}$ y $17 .^{\circ}$, y caminando durante treinta días con sus noches consiguieron llegar a Francia. Una parte de estos guerrilleros debían salir de España en tren, pero una delación hizo caer al grupo en manos de la policía. Finalmente, alrededor de treinta hombres, incluido el propio Grande, consiguieron alcanzar la frontera. Para ellos comenzaba una nueva etapa, que tampoco iba a ser un camino de rosas: el exilio.

En el monte quedaron algunos grupos pertenecientes a los sectores $23 .^{\circ}$ y $17 .^{\circ}$, que, poco a poco, se habían ido aislando de la organización comunista. Uno de ellos era el encabezado por Francisco Serrano, que junto a la mítica Teresa Pla, la Pastora, fueron los últimos guerrilleros aragoneses: su última acción está datada en 1954, año en que Francisco cayó abatido por la guardia civil en una masía cerca de Tarragona. En cuanto a la Pastora, sobrevivió escondida en el monte hasta 1964, cuando fue capturada cerca de la Seo de Urgel. ${ }^{283}$ Otro de los grupos que no huyeron a Francia en el

283 Más información acerca de Francisco Serrano y Teresa Pla, en Mercedes Yusta, La guerra de los vencidos..., op. cit., pp. $91-99$ (para Francisco) y 112-116 para (Teresa Pla). 
momento de la evacuación general fue el de José Vicente Zafón, Pepito de Mosqueruela, que fue abatido por los disparos de la guardia civil en mayo de 1952 cerca de Alcalá de la Selva. En el informe policial se describe a Pepito como «bandolero activo, secretario de organización del $17 .{ }^{\circ}$ sector de la AGLA», y se enumeran sus antecedentes y actividades en el seno de la guerrilla:

Antes de iniciarse el Glorioso Movimiento Nacional perteneció a la CNT, siendo un gran propagandista de estas ideas, viéndosele desde siempre unido a los dirigentes y asistiendo a todos los mítines que allí se celebraban.

Iniciado el Alzamiento y habiendo quedado el pueblo de su naturaleza y vecindad (Mosqueruela) bajo el dominio rojo desde los primeros momentos, tomó parte activa en impedir triunfase el movimiento nacional en aquella población, formando parte de los comités revolucionarios y enrolándose voluntario en el ejército marxista, ignorándose su actuación y graduación que alcanzó.

Terminada la campaña, fue detenido, permaneciendo unos meses en un campo de concentración y una vez puesto en libertad regresó al pueblo de Mosqueruela.

El día 21 de octubre de 1945, al efectuar un registro en su masía por tener noticia de que en ella se refugiaban algunos bandoleros, fue hallada una carta que el bandolero Jesús Caellas Aymerich, Carlos y Catalán, dirigía a sus familiares en Barcelona, y percatándose de ello el informado se dio a la fuga, uniéndose a los forajidos desde dicha fecha y habiendo intervenido en los siguientes hechos delictivos [...].

El informe continúa describiendo los dieciséis hechos delictivos que se imputan a Pepito desde mayo de 1946 hasta enero de 1952, y que comprenden varios atracos, sabotajes y un total de catorce muertes, incluidas las producidas en Gúdar en septiembre de 1947. ${ }^{284}$ En el grupo de Pepito se encontraban también Manuel Pérez Cubero, Rubio, que en ese momento era jefe del $17 . .^{\circ}$ sector y que, aunque nacido en Benicalap (Valencia), había vivido mucho tiempo en esta zona de la provincia de Teruel, así como Florencio Guillén, el Viejo, de Gúdar, que fueron vistos por última vez en la zona de Aliaga en marzo de $1953 .{ }^{285}$ Los informes policiales callan a partir de esta fecha, y, por tanto, desconocemos la suerte que finalmente corrió este grupo, aunque Manuel Pérez Cubero consiguió pasar a Francia en circunstancias que desconocemos. Pero, en resumen, parece

284 AHPT, sección Gobierno Civil, caja 1031, carpeta 40.

285 AHPT, sección Gobierno Civil, caja 1031, carpeta 38. 
que los guerrilleros más ligados a la zona fueron los más reacios a abandonarla, o quizá los más descuidados por el PCE a la hora de proceder a la evacuación. En todo caso, habituados a la dinámica de la vida en el monte y fuertemente ligados a la tierra y a los conflictos y redes locales, los "guerrilleros autóctonos» más significados y míticos, como Pepito de Mosqueruela, Francisco o la Pastora permanecieron en su tradicional zona de actuación hasta el final.

\section{El final de la guerrilla altoaragonesa}

A principios de 1949, la organización guerrillera comunista prácticamente había dejado de existir en la provincia de Huesca. Ángel Bellostas y Enrique Vistué, jefe y responsable político de la Agrupación, respectivamente, habían sido detenidos en el pueblo de Blecua en la primavera de 1948 y fueron fusilados en la cárcel de Torrero un año después. Bellostas fue acusado de haber delatado a miembros del PCE, y durante su estancia en la cárcel se hizo pública en una publicación comunista una nota firmada por la "AGLA-sector Aragón» sentenciándolo a muerte "por traidor y delator», puesto que, se decía, había sido detenido sin ofrecer resistencia y se afirmaba que se había convertido en confidente de la policía. Ni siquiera su ejecución acabó con esta campaña de difamación, que revela la psicosis propia de la clandestinidad en la que vivían los hombres del PCE. 286

Al mando de la Agrupación había quedado Narciso Villellas, de Alquézar, que murió poco después de hacerse cargo de la organización guerrillera, en otoño de 1948, en un encuentro con la guardia civil en Binéfar. Era el principio del fin. En enero de 1949, la Agrupación del Alto Aragón se reducía al grupo de Drole, con cuatro guerrilleros; el de Manuel Cosculluela (nuevo responsable de la Agrupación), con otros cuatro; el del Americano, con tres; y los dos guerrilleros que componían el grupo de Narciso. La red de apoyos era prácticamente inexistente. Desde ese momento, no se produjo apenas actividad guerrillera; las acciones se limitaban casi por entero a la propaganda. Pese a ello, en Mundo Obrero se anunciaba a bombo y platillo el «auge de la actividad guerrillera en el Alto Aragón», y se afirmaba que «la labor política de los guerri-

286 Mundo Obrero, provincial de Huesca, 1949. 
lleros los une más y más cada día con los campesinos y los protege de los embates franquistas». Se anunciaba el reparto de propaganda republicana y comunista en Graus, Benabarre, Tolva, Viacamp, Barbastro, Selgua, Pomar, Sariñena, El Grado y Coscojuela de Sobrarbe, que más podemos atribuir a la actividad de las redes de resistencia que a los propios guerrilleros. También se multó a caciques y falangistas de Guardia, Lastanosa y Monfort por sus actividades estraperlistas. Se aludía también al ajusticiamiento del teniente de alcalde de Barbuñales, el falangista Ángel Rufos, extremo que no hemos podido confirmar por medio de otras fuentes. Pero al mismo tiempo hubo un importante incremento de las acciones de las contrapartidas, y el cerco se fue cerrando en torno a los guerrilleros. $^{287}$

En algún momento del invierno de 1948-1949 (probablemente a principios de 1949), los guerrilleros, que se encontraban reunidos en un bosque cerca de La Pardina (en el valle de La Fueva), fueron cercados por la guardia civil y sufrieron un fuerte tiroteo. No hubo bajas entre ellos, pero se perdió el receptor que poseían y que constituía su medio de estar en contacto permanente con las consignas emitidas por el PCE a través de Radio Pirenaica. Fue la señal de alarma que les hizo ver crudamente que el trabajo de la Agrupación se venía abajo y tenía pocas posibilidades de continuar. Por este motivo, se decidió que Manuel Tosán y otro guerrillero llamado Enrique pasasen a Francia para informar a la dirección de la situación, que era de completa inacción y de gran aislamiento; a pesar de la complicidad de una parte de la población, los guerrilleros tenían incluso dificultades para abastecerse y se veían obligados a recoger hortalizas y frutas de los huertos, debido a que las redadas habían hecho caer a una parte importante de los apoyos de la guerrilla y habían atemorizado al resto. Probablemente, el resto del grupo pasó también a Francia hacia el verano de 1949, pero no existe ninguna constancia de la suerte que finalmente corrieron. El 23 de julio de 1949 aparecen por última vez noticias de la acción guerrillera en el Alto Aragón en Mundo Obrero, acciones que consistieron en propaganda y mítines en Panillo y Torres del Obispo, y propaganda y banderas en Santa María de Buil, Mediano y Castejon de Sobrarbe. Las acciones se atribuyen a «hombres de la AGLA que operan

287 Mundo Obrero, 6/1/49. Edición de París. 
en estas zonas», apreciación que consideramos errónea; creemos que más bien se trataba de las últimas acciones de los guerrilleros altoaragoneses, dirigidos por Manuel Cosculluela, antes de abandonar definitivamente la zona. Y el mes de julio se desató una ola represiva contra la población, que ya no contaba con la defensa de los guerrilleros. Los puntos más castigados fueron aquellos que se habían destacado en la ayuda a los guerrilleros, como Santa María de Buil (población en la que, como veremos, se había dado refugio a los últimos guerrilleros que penetraron en la zona, que eran de militancia anarquista). Los destacamentos de Mediano, Adahuesca, Bárcabo, Sarsa de Surta, Naval, El Grado, Broto, Castejón de Sobrarbe y Coscojuela de Sobrarbe se dedicaron, durante ese verano, a realizar razias en los pueblos de sus respectivas demarcaciones, «dirigidos por un teniente coronel conocido por su ferocidad» y consciente de que la actividad guerrillera, como tal, había desaparecido de la provincia de Huesca. $^{288}$

Tenemos constancia de una última incursión guerrillera desde Francia, pero en este caso se trataba de un grupo de miembros del Movimiento Libertario, que se introdujeron en España en la primavera de 1949 para efectuar una misión concreta que no pudieron llegar a cumplir, y que en ningún momento tomaron contacto con lo que pudiese quedar de la AGAA. Esta partida estaba integrada por once individuos, exiliados anarquistas españoles reclutados en Toulouse por el comité de la CNT-FAI para llevar a cabo la voladura de un tren en la provincia de Zaragoza. En principio, la voladura había sido encargada al grupo de los Maños, un "grupo de afinidad» anarquista constituido alrededor de Wenceslao Giménez Orive, zaragozano y miembro del Movimiento Libertario aragonés, al que había representado en el Pleno Nacional de Regionales de 1947. Wenceslao conoció al guerrillero anarquista Facerías en un viaje a Francia en agosto de 1948, y a través de él se unió a un grupo de guerrilleros rurales anarquistas. Pero la pasividad de éstos le hizo abandonar el grupo, pues su intención al unirse a la guerrilla era pasar a la acción directa. Por lo tanto, acabó constituyendo un grupo de acción con sus amigos de Zaragoza,

288 Paloma Fernández Pancorbo, El maquis..., op. cit., pp. 76-82. El entrecomillado y las noticias sobre las razias de la guardia civil, en Mundo Obrero, 7/7/49. Edición de París. 
según la tradición de los «grupos de afinidad» anarquistas, ${ }^{289}$ y se separó de Facerías. Éste es el origen del grupo de los Maños, constituido, de acuerdo con los datos aportados por Antonio Téllez, por Wenceslao Giménez, Rodolfo, M.A., Simón Gracia Fleringan y Plácido Ortiz, a los que se unió en febrero de 1949 Aniceto Pardillo, el Chaval. Se incorporaron a la vida clandestina de Barcelona y colaboraron con Quico Sabaté; también pasaron de Francia a Aragón para realizar acciones concretas. Pero tenían muy poco contacto con la organización libertaria, que no apoyaba la lucha armada: actuaban más bien por su cuenta. Una de las misiones que planearon, y que finalmente no llegaron a ejecutar, consistía en un plan para matar a Franco en la cuesta de La Muela, cerca de Zaragoza, cuando éste, de visita en la capital aragonesa, pasara por allí en su coche oficial. ${ }^{290}$

El grupo que salió de Toulouse para realizar la voladura de tren que los Maños habían dejado pendiente estaba comandado por Rufino Carrasco, que actuaba además como guía. Penetraron en mayo de 1949 por el puerto de Parzán, acompañados por un tal Noguero que les condujo hasta la peña Montañesa. Pasaron por Santa María de Buil, pueblo de gran tradición en la ayuda a las guerrillas y en el que contaban con apoyos de confianza. El 30 de mayo, al intentar cruzar el Ebro, mantuvieron un tiroteo con el alcalde de Alborge, que resultó muerto. La guardia civil salió en su persecución y logró capturar a siete de ellos; los restantes murieron por los disparos. Trasladados al cuartel de Caspe, sufrieron un duro interrogatorio (con golpes, palizas, etc.) y fueron maltratados incluso por las mujeres y niños del cuartelillo, para ser finalmente transferidos a la cárcel de Huesca. Fueron todos condenados a la última pena, excepto Ángel Fernández y José Ibáñez, a quienes en razon de su juventud se les conmutó la pena por la de 30 años de reclusión mayor. El resto del grupo fue fusilado el 10 de mayo de $1950 .^{291}$

289 El grupo de afinidad se caracteriza por llevar a cabo acciones de tipo individual en nombre del proletariado, como expropiaciones de bancos o ajusticiamientos de «enemigos del proletariado». El más conocido es el grupo «Nosotros», formado en Barcelona en 1931 y compuesto, entre otros, por Francisco Ascaso, Buenaventura Durruti, Joan García Oliver, Aurelio Fernández, Ricard Sanz, Miquel García Vivancos y Antonio Ortiz.

290 Antonio Téllez, La guerrilla urbana en España: Facerías. Ruedo Ibérico, París, 1974, pp. 147-171.

291 Entrevista, Ángel Fernández. Toulouse, 12 de diciembre de 1998. 
Éste es el último episodio guerrillero en la provincia de Huesca del que queda constancia, aparte del paso de los guerrilleros de Levante que iban evacuando la zona y pasando a través del Pirineo entre 1950 y 1952. ${ }^{292}$ Cuatro años después, el 4 de junio de 1956, un destacamento de la guardia civil descubrió un zulo repleto de armas y munición en una cueva oculta entre la vegetación de las faldas de la peña Montañesa que los guerrilleros habían abandonado allí en su huida a Francia. ${ }^{293}$ Con ese hallazgo se dio definitivamente por cancelado el tema de la guerrilla pirenaica, que había dado pie a tanta leyenda y mito transmitidos de boca en boca a través de los valles y las llanuras altoaragonesas, pero que también había provocado, directa o indirectamente, mucho dolor y sufrimiento. Muchos pueblos, sobre todo en el Sobrarbe, quedaron marcados por el duro trato que el régimen franquista deparaba a las zonas que se convertían en refugio de guerrilleros, con registros continuos, detenciones arbitrarias, palizas, torturas.

Tanto esta zona como el Maestrazgo turolense, comarcas guerrilleras por excelencia, han conservado una profunda huella causada por los acontecimientos que se derivaron de la presencia de las guerrillas. La represión franquista vino a sumarse a una serie de problemas estructurales que ambas presentaban en la época que nos ocupa, como la falta de infraestructuras de todo tipo, desde las comunicaciones hasta el tejido industrial, una economía pobre sustentada en la ganadería y, sobre todo, en una agricultura más orientada a la supervivencia que al mercado y un lento pero inexorable proceso de despoblación. Estas características favorecieron probablemente el asentamiento de los guerrilleros; el hecho de que estas zonas concentren la actividad guerrillera, como anteriormente habían concentrado la experiencia revolucionaria de las colectividades, puede relacionarse con las dificultades estructurales y el problemático desarrollo de estos territorios. Podemos decir, por lo tanto, que la llama insurreccional prendió en una zona altamente inflamable.

292 Informe sobre bandolerismo, s.f. Centro de Estudios Históricos de la Guardia Civil, Dirección General de la Guardia Civil. Ángel Fernández, Testimonio de un país que ya no existe: República española. Testimonio mecanografiado. Sin publicar. Consultado gracias a la amabilidad de su autor, que formaba parte de este grupo de guerrilleros libertarios.

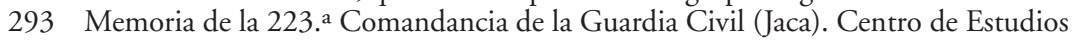
Históricos de la Guardia Civil, Dirección General de la Guardia Civil. 


\subsection{El largo brazo de la represión ${ }^{294}$}

Nadie sabe lo que es ser perseguido si no ha pasado por ello y la persecución no ha sido constante y activa, llevada a cabo con deliberación y determinación y ahínco y sin pausa, con perseverancia o con fanatismo, como si los perseguidores no tuvieran otra cosa que hacer en la vida que darle a uno alcance y antes buscarlo, acosarlo, seguirle la pista, localizarlo y a lo sumo aguardar la ocasión mejor para ajustarle las cuentas.

(Javier Marías, Mala indole)

No es nuestro propósito analizar la represión franquista de posguerra en toda su amplitud, labor que ya han realizado numerosos historiadores. La intención de este capítulo es narrar y tratar de comprender las formas específicas de represión que el Estado franquista aplicó en Aragón a la lucha contra la guerrilla, y sobre todo destacar de qué modo ese proceso represivo afectó a la sociedad rural aragonesa en su conjunto. ${ }^{295}$ Muchos autores han resaltado el hecho de que la represión es un componente estructural del régimen franquista; ${ }^{296}$ la violencia ejercida desde el Estado se convirtió, desde el momento mismo de la sublevación militar, en la principal fuente de legitimación del régimen. A esta fundación del Estado por el recurso a la violencia hay que añadir que, como indica Eduardo González Calleja, «la dictadura franquista siempre confundió el orden

294 Ver el libro coordinado por Santos Juliá, Víctimas de la guerra civil. Temas de Hoy, Madrid, 1999. La tercera parte, "La represión de la posguerra", elaborada por Francisco Moreno, constituye una buena síntesis de la represión de posguerra en toda España, con especial atención a la represión dirigida contra la guerrilla y todos aquellos individuos relacionados con ella. En esta visión global se observa cómo varias tácticas o instituciones represivas que vamos a tratar aquí en el marco de la región aragonesa, como el somatén, las contrapartidas, las redadas indiscriminadas o la «ley de fugas», son utilizadas en todo el territorio español durante los años de actividad de la guerrilla. En este sentido, y como cabía esperar, la represión es mucho más homogénea que la propia guerrilla, que presenta notables diferencias según las zonas.

295 Para analizar la represión franquista en Aragón, centrada durante el período de la guerra civil pero con análisis que apuntan hacia la función social de la represión en el Estado franquista y su aplicación en la inmediata posguerra, el estudio clásico y de obligada referencia es el de Julián Casanova y otros, El pasado oculto..., op. cit., recientemente reeditado por Mira Editores.

296 Entre ellos, destacamos el artículo de Ángela Cenarro, «Muerte y subordinación en la España franquista: el imperio de la violencia como base del "Nuevo Estado"», Historia Social, n. ${ }^{\circ} 30,1998$, pp. 18-19. 
público y la defensa del orden político-social con la represión. Desde este punto de vista, la criminalización de los individuos e instituciones leales a la República era la alternativa políticamente más útil, y socialmente la más adecuada al ambiente de venganza colectiva que se respiraba, frente a la dificultosa fundamentación legal de un régimen directamente emanado de un golpe de Estado y de un cruento conflicto civil que englobó diversos procesos de violencia a gran escala». ${ }^{297}$ En resumen, el Estado franquista había nacido de un golpe militar y de la victoria tras una sangrienta guerra civil, y se consolidó mediante un durísimo proceso de represión cuyo objetivo era eliminar toda oposición, real o potencial, y paralizar por medio del terror a todo un sector de la sociedad, el que no había apoyado el levantamiento de julio del 36. En palabras de Paul Preston, «el uso del terror, como inversión tanto a corto como a largo plazo, fue un elemento esencial de la estrategia de Franco en su condición de general y de dictador. Durante la guerra y mucho después de la misma, sus enemigos que no habían sido eliminados físicamente quedarían paralizados por el terror y forzados a buscar la supervivencia en la inacción». ${ }^{298}$

Este régimen de terror fracturó profundamente a la sociedad civil; la convivencia entre sectores ideológicamente opuestos era imposible, porque el régimen no permitía la existencia misma de un sector opositor. La cultura política del franquismo se desarrolló, en esa primera posguerra, como una cultura de la división y de la exclusión: los opositores al régimen ya no eran españoles, eran la "antiespaña»; los verdaderos patriotas debían denunciarlos allí donde se encontrasen, pues, de lo contrario, serían considerados cómplices de la subversión. De este modo, la delación y la sospecha se transformaron en un ingrediente básico de la vida social española. Como en todo régimen de corte totalitario y basado en el terror, el Estado franquista convirtió a los ciudadanos en policías de sus propios vecinos, incluso de su propia familia.

El modo en el que un sector de la sociedad se implica en la represión de Estado es sumamente complejo. En este proceso no solamente actúan

297 Eduardo González Calleja, «Violencia política y represión en la España franquista: consideraciones teóricas y estado de la cuestión", en Roque Moreno y Francisco Sevillano (eds.), El franquismo. Visiones y balances. Publicaciones de la Universidad de Alicante, Alicante, 1999, pp. 119-150.

298 Paul Preston, La política de la venganza..., op. cit., p. 65. 
las convicciones políticas sino también las redes informales que conforman una comunidad, los viejos conflictos entre individuos, intereses personales, antiguas deudas de gratitud o de odio... Ya vimos algo de esto cuando analizábamos la conflictividad en el campo aragonés durante los años cuarenta, sobre todo en la inmediata posguerra. Pero interesa destacar el modo en que un Estado dictatorial transforma a un sector de los ciudadanos en instrumentos de su política represiva. En este contexto, el de una sociedad controlada por medio del terror y en la que el enfrentamiento entre «vencedores» y "vencidos» no sólo no se apacigua sino que se fomenta, la palabra clandestinidad adquiere un significado muy profundo. Significa que quien entra en la clandestinidad no debe guardarse únicamente de las fuerzas represivas o de los representantes del Estado, sino de cualquier ciudadano o ciudadana, que puede convertirse en un potencial enemigo. Significa vivir en una situación de auténtico «exilio interior». Nunca como en esta época del primer franquismo se produjeron tantas delaciones, acusaciones y chivatazos, que, dicho sea de paso, se debían tanto al deseo de saldar viejas cuentas pendientes como al temor hacia el régimen, que hacía que muchas personas temiesen ser represaliadas si no daban cuenta a las autoridades de las actividades opuestas al régimen de las que tenían conocimiento. Y esto es válido también para las delaciones que apuntaban a los guerrilleros antifranquistas o sus colaboradores: provenían, en parte, de sectores próximos al régimen o que se sentían amenazados por las acciones de los guerrilleros, pero también, en algunos casos, de personas que temían ser acusadas de colaborar con la guerrilla. ${ }^{299}$

299 La importancia de las denuncias y la cooperación de los ciudadanos con el sistema policial en los estados totalitarios es señalada por Francisco Miguel de Toro Muñoz para el caso de Austria y Alemania durante el Tercer Reich. Sería muy interesante realizar una investigación del mismo tipo referida a la España franquista, para averiguar el grado de implicación de la población en el aparato represivo y la posible aplicación al caso español de estas afirmaciones: "Los nuevos planteamientos de investigación nos permiten comprender que, gracias a sus esfuerzos, el Tercer Reich se convirtió en una sociedad que se vigilaba y se controlaba a sí misma. Asimismo, la dictadura intentó implicar a toda la población en la eliminación de grupos de enemigos (que ella misma había creado anteriormente), mediante la participación activa en los distintos juegos represivos. Con esta política se pretendía convertir al conjunto de la población en una parte integrante del régimen, coaccionando al grueso de la población hacia un estado de conformidad o de apatía. La denuncia pasó a ser uno de los elementos de relación interactiva más importantes entre la población, el complejo policial y los mecanismos de control social». Francisco Miguel de Toro Muñoz, "Policía, denuncia y control social: Alemania y Austria durante el Tercer Reich», Historia Social, n. ${ }^{\circ}$ 34, 1999, pp. 117-134, cita en p. 120. 
La opción por la lucha armada frente a un régimen dictatorial no es fácil ni evidente. Esta opción implica no sólo entrar en una situación de clandestinidad, sino además en una guerra contra los representantes de un Estado que se percibe como opresor. Los componentes de un grupo armado se convierten en la amenaza más directa a la estabilidad del Estado. Esto significa que se exponen a las medidas más duras que ese Estado pueda aplicar, sin las garantías, además, que supone el pertenecer a un ejército regular: garantías en cuanto al trato recibido y al reconocimiento de la legitimidad de la acción armada. Ya hemos visto, cuando desarrollábamos la trayectoria de la guerrilla en Aragón, el trato despiadado al que eran sometidos los guerrilleros cuando caían en manos de las fuerzas represivas. Respecto a la cuestión de la legitimidad de la lucha, una de las armas que el régimen franquista empleó contra la guerrilla fue la dialéctica: los guerrilleros eran calificados, generalmente, de «bandoleros» (y no de «terroristas», significativamente), lo cual suponía despolitizar su acción y deslegitimarla frente a la ciudadanía. Pero la lucha del guerillero o guerrillera queda legitimada en la medida en que esta lucha es vivida como la defensa de los derechos de la mayoría, del pueblo (como lo entienden las organizaciones obreras y, concretamente, en el caso que nos ocupa, el Partido Comunista) frente a la opresión ejercida por una dictadura que se sirve de la represión y el miedo para mantener su propia legitimidad.

Por otra parte, el Estado franquista se contradice a sí mismo constantemente cuando alude a la condición de «bandoleros» (y, por tanto, de delincuentes comunes) de los guerrilleros. Continuamente está haciendo diferenciaciones entre ambos. Ante unos robos producidos en Teruel en mayo de 1947, por ejemplo, el gobernador civil escribe a la Dirección General de Seguridad: "Las circunstancias que concurren en el hecho apuntado hacen sospechar que se trata, no de auténticos bandoleros, sino de individuos que aprovechándose de la intranquilidad de los actuales momentos cometen estos robos». ${ }^{300}$ De forma contraria, además, el franquismo "politiza» en ocasiones ciertos delitos comunes cuando pueden afectar a la estabilidad del régimen, sobre todo durante los años comprendidos entre 1943 y 1947, en los que el compromiso de Franco con las

300 AHPT, sección Gobierno Civil, caja 1085, carpeta 51. La cursiva es mía. 
potencias del Eje y el desenlace de la segunda guerra mundial, combinado con las acciones de la guerrilla, hicieron peligrar esa estabilidad. Un ejemplo: en un informe dirigido a la Dirección Nacional de Provincias (DNP) en julio de 1947, el jefe provincial de Falange en Zaragoza informaba, en el apartado «actividades políticas clandestinas», acerca de varios atracos a mano armada en la ciudad de Zaragoza (que, aclaraba, no eran «actividades políticas clandestinas», pero que se narraban por la reacción de repulsa producida en la población). Los culpables fueron condenados a garrote vil. Encontramos cierta relación entre esta dureza represiva y el hecho de que, en el mismo informe, el jefe provincial manifestase su gran preocupación por la "carrera de los precios [...] que llegan a un extremo en el que los obreros y la clase media carezca de lo más indispensable», llegando a decir que ello podría llevar incluso a la desaparición del régimen. ${ }^{301}$ Aquí encontramos, de nuevo, la crisis de legitimidad de un Estado incapaz de asegurar las necesidades básicas de sus propios ciudadanos, que buscaba esa legitimidad en demostraciones de fuerza y alardes represivos como el descrito. Esta misma tendencia aparecería en la lucha frente a la guerrilla. Por un lado, la existencia misma de la guerrilla trataba de ocultarse con una férrea censura de prensa y con la aplicación a los guerrilleros de calificativos como «atracadores», «bandoleros», «asesinos», etc. Y por otro, se producían constantemente demostraciones del poder represivo del régimen frente a esa guerrilla cuya existencia se trataba de negar: en otro documento, el jefe provincial de Falange de Zaragoza informaba acerca de varias sentencias de muerte aplicadas a «atracadores y asesinos», que eran «vistas con agrado" por los simpatizantes del régimen, «ya que consideran es una muestra más de la virilidad de nuestro Caudillo y quienes le siguen». ${ }^{302} \mathrm{La}$ frase es lo suficientemente expresiva y no requiere comentario.

La represión contra los guerrilleros empleó, por supuesto, armas mucho más poderosas que las derivadas de la manipulación ideológica o semántica. El régimen se dotó, entre otras cosas, de un entramado legal que determinaba y regulaba los medios con que afrontar la lucha antiguerrillera. Esta regulación, de todas formas, encubría multitud de prácticas

301 Jefatura Provincial de Zaragoza, informes mensuales, julio de 1947, AGA, sección Presidencia, DNP, caja 189.

302 Jefatura Provincial de Zaragoza, informes mensuales, febrero de 1946, AGA, sección Presidencia, DNP, caja 189. 
irregulares, no legisladas pero admitidas en el funcionamiento cotidiano de las fuerzas represivas, como la tortura, las detenciones más o menos arbitrarias, la aplicación de la «ley de fugas»... Pero, como decimos, las prácticas irregulares quedaban cubiertas por el andamiaje legal construido por el régimen para sustentar la represión, que era su principal instrumento político en el interior. Como vamos a ver a lo largo de este capítulo, la principal víctima de la represión no fueron los guerrilleros, aunque éstos también la sufrieron, y muy duramente, sino la población civil que los apoyaba. La represión contra los guerrilleros fue una represión física, descarnada, en la cual toda práctica era válida y no precisaba justificación: los guerrilleros eran "cazados» como alimañas, se desplegó contra ellos un aparato militar sencillamente impresionante, rara vez eran capturados vivos y, cuando esto ocurría, se les sometía a tortura para que delatasen a sus compañeros o sus escondites. Una prueba de esta represión la constituyen las continuas caídas de jefes de las Agrupaciones, que ya hemos descrito: Vicente Galarza, Ángel Fuertes, Pelegrín Pérez, Ángel Bellostas, Enrique Vistué, Narciso Villellas...; sólo Joaquín Arasanz, que se libró de la pena de muerte gracias a las influencias de su familia, vivió lo sufiente para ver el final de la lucha guerrillera y del propio franquismo.

No es para justificar la represión contra los guerrilleros para lo que el franquismo dicta leyes represivas, puesto que la lógica de la lucha antiguerrillera justifica y legitima por sí misma el recurso a la violencia, sino para poder controlar y reprimir a la sociedad civil. Dichas leyes comenzaron a aparecer antes incluso del final de la guerra civil: el 9 de febrero de 1939 se promulgó la Ley de Responsabilidades Políticas, que materializaba tanto la voluntad represiva contra los que no habían apoyado el golpe de Estado del 18 de julio como el afán incautatorio del nuevo régimen, pues entre las penas que imponía se encontraba la incautación de los bienes del acusado o acusada. En marzo de 1940 se promulgó la Ley para la Represión de la Masonería y el Comunismo, y un año después, en marzo de 1941, la Ley de Seguridad del Estado. La Ley de Rebelión Militar data de marzo de 1943. Pero la ley que proporcionó el instrumento jurídico más implacable y eficaz en el asunto concreto que nos ocupa es el Decreto-Ley para la Represión del Bandidaje y el Terrorismo, de 18 de abril de 1947, que supone una auténtica declaración de guerra contra los grupos de guerrilleros que actuaban en todo el territorio nacional y contra los civiles que les apoyaban. En virtud de esta ley, que derogaba la anterior Ley de Seguridad del Esta- 
do, actitudes como dar de comer a un grupo de hombres armados, ocultar información a las fuerzas represivas o no colaborar activamente con ellas se castigaban con dureza, en ciertos casos incluso con la pena de muerte. Por el contrario, las detenciones arbitrarias, la aplicación de la «ley de fugas» y otras acciones represivas quedaban justificadas legalmente. La Ley del 18 de abril de 1947 significaba la promulgación de un estado de terror en las zonas guerrilleras; de hecho, en Teruel su publicacion coincidió con la declaración del «estado de guerra» en la provincia, que conllevaba el toque de queda a las ocho de la tarde, la prohibición de abandonar las poblaciones de noche o el cierre de tabernas y locales de sociabilidad, y otra medida con fuertes implicaciones para la población rural, como era la obligación de evacuar las masías antes del 31 de agosto de 1947. Los masoveros debían dejarlas a las ocho de la noche y depositar las llaves en el cuartelillo de la guardia civil de la localidad más cercana. Los habitantes de las masías tenían que buscar por sí mismos un lugar para pernoctar, y, ante el enorme trastorno que ello suponía, muchos decidieron abandonar sus tierras y emigrar a los núcleos urbanos próximos o incluso a Barcelona. La medida afectó especialmente a los enclaves de las sierras del Maestrazgo, Gúdar y Javalambre, así como al Maestrazgo de Castellón, provincia en la que también se llevó a cabo el desalojo, y sobre todo a los términos de Fortanete, Aliaga, Castellote y Puebla de Benifasar.

Sin embargo, no todos los masoveros acataron sin resistencia esta orden, como revelan las fuentes orales. Algunas campesinas relatan cómo se quedaban escondidas en la masía durante la noche para poder cocer el pan, que tradicionalmente se elaboraba de madrugada en las masías, y describen el terror que sentían a ser descubiertas por la guardia civil y a que las considerasen colaboradoras de la guerrilla. Los masoveros llegaron, en algunos casos, a organizarse para eludir el control de la guardia civil y poder permanecer en las masías, dando lugar a lo que podríamos calificar de actitud de rebeldía frente a una medida que para ellos era injusta e incomprensible y que trastornaba su quehacer cotidiano:

En una masía... ahí hicieron el acuerdo una partida de masías, porque la gente, aunque era obligatorio ir al pueblo, abandonar las masías, la verdad es que no obedecíamos, porque bajo manga, no es que se quedara toda la familia, pero siempre se quedaba uno u otro, o se juntaban tres o cuatro masías y de cada masía se quedaba uno en una, o cada uno en su casa, en fin, que... jademás es que se necesitaba! Los animales, allí toda la noche, masías que entonces andando pues costaba tres horas, y tres horas y media, o cuatro horas de ir de 
la masía al pueblo. Tú fíjate a la hora que tenían que abandonar los animales y a la hora que los podían atender, pues se quedaba uno y a trancas y barrancas, pues... pues se hicieron el acuerdo que, bueno, que si se veía la guardia civil o se veía algún peligro de que estuviera la guardia civil por ahí, pues poner una señal en la ventana de una casa para irse todos al pueblo por si acaso la guardia civil se quedaba por la noche por ahí $[\ldots] .^{303}$

La efectividad de la medida del desalojo de masías fue sólo relativa, ya que motivó el acercamiento de los guerrilleros a los núcleos de población en busca de abastecimiento, lo que provocó el pánico de algunos alcaldes franquistas. ${ }^{304} \mathrm{El}$ pánico llevó a varios de ellos a solicitar el aumento de las dotaciones de la guardia civil en sus respectivas poblaciones, como sucedió a lo largo del año 1947 en las poblaciones turolenses de Orihuela del Tremedal, Pitarque, Linares de Mora, Tramacastilla, Villar del Cobo, El Cuervo, Tramacastiel y Aldehuela. Además, esta medida tuvo que ser reforzada con otras, como la prohibición de llevar al campo más comida de la necesaria para la jornada. Como puede observarse, el control de las autoridades represivas sobre los campesinos llegó a ser verdaderamente asfixiante, y nos hace preguntarnos si, realmente, el objetivo final de tales medidas era acabar con la guerrilla, o si no era también un objetivo prioritario la paralización, por medio del terror y el control exhaustivo, de los sectores del campesinado potencialmente hostiles $\mathrm{o}$ indiferentes al régimen.

La famosa «ley de fugas» también merece un breve comentario. La amplitud de su aplicación es sencillamente aterradora, aunque resulta francamente difícil conocer su incidencia real, puesto que en los informes policiales rara vez se alude a ella directamente, sino mediante perífrasis como «los prisioneros intentaron huir [a veces, «debidamente esposados»], resultando muertos». Según Francisco Moreno, la ley de fugas «es una vieja forma de terror de Estado, expeditiva, con todo un historial en la España contemporánea, y que en los años de represión franquista recobró más importancia que nunca». ${ }^{305}$ Por tanto, en su aplicación podemos ras-

303 Entrevista, J.B. Cañada de Benatanduz, 26 de julio de 1997.

304 Como, por ejemplo, el alcalde de Valdelinares, que en mayo de 1948 pidió un destacamento de la guardia civil alegando que «al no poder sumunistrarse [en las masías] es más fácil que puedan presentarse en el pueblo». AHPT, sección Gobierno Civil, caja 1130, carpeta 25.

305 Francisco Moreno, Córdoba en la posguerra (la represión y la guerrilla, 1939-1950). Francisco Baena, Córdoba, 1987, p. 51. 
trear una continuidad de largo plazo, que no sólo se manifiesta en las formas de conflictividad sino también en las formas de represión, que son las mismas utilizadas por el autoritarismo tradicional, con la diferencia de que ahora cuentan con todo un aparato de Estado para conseguir sus fines y con una legislación para legitimarlos. Y lo mismo podemos decir de la medida de desalojar las masías y reagrupar a los campesinos en los núcleos de población, medida que no sólo tenía como objeto privar de sus apoyos a los guerrilleros, sino también convertir a los campesinos en una masa fácilmente controlable: dicha medida ya había sido utilizada en otras ocasiones para luchar contra guerrillas campesinas; por ejemplo, por el general Weyler en Cuba o contra las guerrillas carlistas en el Maestrazgo, lugar donde Weyler aprendió esta táctica. Lo cual sugiere, de paso, que existe una "geografía de la conflictividad» rastreable en el largo plazo, ya que el Maestrazgo arrastraba tras de sí una larga historia de conflictos característicos de sociedades campesinas en las que un poblamiento disperso dificultaba el control de la población.

Pero, en suma, se trata de mostrar que los métodos no eran del todo nuevos. De hecho, en un «manual» referente a la lucha contra la guerrilla, calificada de "bandolerismo contemporáneo», se sugería emplear contra ella los mismos métodos que se utilizaron para acabar con el bandolerismo tradicional. ${ }^{306}$ Lo novedoso es la amplitud y, sobre todo, la impunidad con que fueron aplicados, gracias a un aparato legislativo y represivo con el que ningún sistema autoritario en la España contemporánea había contado hasta ese momento. $Y$ es que el franquismo se manifestó como «un sistema político en el que se crea una interdependencia entre régimen y modo de dominación de clase a través de una fórmula política - la que habían estado buscando las derechas españolas desde 1808- que, por fin, da un resultado sólido». ${ }^{307}$ Después de todo, la guerrilla era una amenaza para el régimen, pero, más que nada, era una amenaza para quienes ejercían el poder a nivel local, para las elites políticas y económicas, que eran las que sufrían directamente las acciones guerrilleras. De ahí, además, la implicación de algunos de sus representantes en las acciones represivas,

306 Antonio Díaz Carmona, Bandolerismo contemporáneo. Compi, Madrid, 1969.

307 Eduardo Sevilla-Guzmán y Salvador Giner, "Absolutismo despótico y dominación de clase: el caso de España», Cuadernos de Ruedo Ibérico, n. ${ }^{\circ} 43-45$, enero-junio de 1975, pp. 83-104. 
encuadrados en instituciones civiles como el Somatén, creadas precisamente para proporcionar ( $\mathrm{y}$ a veces para forzar) dicha implicación.

La formación de somatenes fue autorizada por Decreto de 9 de octubre de 1945, pero parece que los primeros pudieron formarse antes en tierras aragonesas. De hecho, en un asalto a la sucursal del Banco de Crédito de Híjar, producido en julio de 1945, ya se registra la acción de varios somatenistas, miembros de la Falange local, que, junto a la guardia civil, mataron a uno de los asaltantes y capturaron al otro. ${ }^{308}$ Los estatutos del Somatén fueron aprobados el 23 de octubre de 1945, y se constituyó con la consideración de «fuerzas auxiliares de la Policía Rural» (es decir, de la guardia civil). En teoría, los somatenes no tenían cariz político, pero en la práctica estaban integrados principalmente por falangistas. Fue una institución que contó con bastante más éxito en Teruel, donde existía un somatén en cada localidad, por pequeña que fuese, que en Huesca, donde han quedado pocas huellas de su actividad. Sus actuaciones más destacadas se produjeron en Salinas de Hoz y en Alborge, donde se registraron violentos enfrentamientos entre somatenistas y guerrilleros.

La actuación de los somatenes enlaza directamente con la actividad de los grupos de falangistas que ejercieron funciones represivas extralegales en la inmediata posguerra, e incluso antes de terminar la guerra civil. A estos grupos civiles se atribuyen acciones como los «sucesos de Calanda» de 1938, y un carácter parecido reviste su actuación contra la guerrilla y, sobre todo, contra los familiares de guerrilleros. Algunos somatenes, como el de Castellote, fueron famosos por su dureza represiva; la familia del guerrillero Francisco Serrano, por ejemplo, guarda un amargo recuerdo de este somatén, al que atribuyen el incendio de su masía. Pero, a diferencia de los primeros momentos de la posguerra, esta vez contaban con el sostén legal de la disposición que permitía la formación de dichos grupos y que les daba carta blanca para entregarse a acciones de venganza y represalia. Algunos personajes de la vida local, como los guardias jurados o los alcaldes (que a la vez eran jefes locales de Falange), formaban regularmente parte de los somatenes, así como algunos antiguos caciques, que frecuen-

308 AHPT, sección Gobierno Civil, caja 1130, carpeta 141, y Memoria de la Comandancia de la Guardia Civil de Teruel (1966). Centro de Estudios Históricos de la Guardia Civil, Dirección General de la Guardia Civil. 
temente militaban en la Falange local. Se trataba, pues, de una institución que proporcionaba el marco legal a la represión extraestatal que los vencedores de la guerra civil siguieron ejerciendo contra los vencidos años después de que terminara ésta. ${ }^{309}$

Aparte del marco legal instituido a nivel nacional, también se tomaron medidas desde los gobiernos civiles y militares de las tres provincias aragonesas, e incluso desde los diferentes ayuntamientos, que regulaban acciones concretas orientadas, sobre todo, al control de la población y a impedir el apoyo a los guerrilleros. Es importante comprobar cómo las autoridades temían este apoyo de la población a la lucha armada, así como la posibilidad de que los guerrilleros se camuflasen entre los habitantes de las zonas afectadas. En Huesca, la alarma se desencadenó a partir de las invasiones de 1944, y aparte de la militarización de la provincia, del Gobierno Militar partieron instrucciones orientadas al control de las poblaciones por parte de los ayuntamientos, en previsión de la infiltración de guerrilleros que pudiesen establecer bases permanentes en la provincia, como finalmente sucedió. El 24 de noviembre de 1944, el Gobierno Militar dio órdenes a los ayuntamientos para que se controlase la entrada y salida de los vecinos de los pueblos a partir del anochecer, «para tener la seguridad de que todo el que marche por las proximidades será considerado como rebelde y no se dará el "Alto quién vive" a nadie». Se estableció, por tanto, el toque de queda, para asegurarse de poder localizar a "posibles rebeldes» que pudiesen tratar de penetrar en los núcleos de población. De la misma fecha es un bando de la Comandancia de la Guardia Civil de Graus, que ordenaba a los vecinos depositar en el puesto de la guardia civil más próximo las armas que encontrasen en el campo, y que preveía la realización de registros domiciliarios. Se anuló también, por orden del Gobierno Civil, la concesión de salvoconductos especiales de fronteras en los partidos judiciales de Boltaña, Benabarre, Fraga, Tamarite y Sariñena, y se suspendió el ejercicio de la caza mayor y menor, «en evitación de confusiones y accidentes inevitables». 310

309 Entrevista, L.S. Castellote, 11 de agosto de 1997.

310 Bando del Gobierno Militar de Huesca del 24/11/44. Bando de la Comandancia de la Guardia Civil del 24/11/44, Circular del Gobierno Civil de Huesca del 17/11/44, Archivo Municipal de Graus, Correspondencia de la alcaldía, caja 27. 
Otra medida tomada por el Gobierno Civil de Huesca se refería a los mendigos. Considerando que «algunos individuos que se dedican a la mendicidad sostienen relación con los rojos españoles huidos», se ordenaba proceder «a la detención de cuantos mendigos circulen por ese pueblo y sus alrededores, ingresándolos en el Depósito municipal a disposición de este Gobierno, a quien darán cuenta urgente, para resolver sobre la situación de aquéllos». Se procedió, pues, a la criminalizacion de aquellos individuos que vivían al margen de la sociedad, relacionándolos con los elementos subversivos infiltrados a través de la frontera. En cierto modo, mendicidad se equiparaba a subversión. Las consecuencias de esta asimilación las podemos imaginar si tenemos en cuenta la situación que se vivía en plena posguerra, con multitud de personas desplazadas de sus hogares, carentes de recursos o huidas de sus domicilios por sus antecedentes «rojos», que no tenían necesariamente relación con los guerrilleros. El control sobre la población se cebó especialmente con estos individuos que escapaban de alguna manera del nuevo orden establecido y que no encontraban un lugar en el «Nuevo Estado» porque, probablemente, no lo tenían. ${ }^{311}$

El control sobre los vecinos, que ya había alcanzado un grado muy alto en la inmediata posguerra, cuando todos ellos tuvieron que rendir cuentas de sus actividades antes de y durante el "Glorioso Movimiento Nacional», se intensificó de nuevo. En todas las alcaldías comenzaron a elaborarse de nuevo informes acerca de los vecinos considerados «sospechosos» por su pasado izquierdista. Este control se prolongó durante el tiempo que duró la alarma acerca de la guerrilla, y se extendió a toda la región aragonesa. Recordemos que, cuando hablamos de la represión franquista, no nos referimos solamente a la eliminación física del oponente. La represión en este período presenta numerosos matices y manifestaciónes: se produce una represión económica, administrativa (como las depuraciones de funcionarios), de género; en la vida cotidiana, en la educación... Medidas como las citadas (el desalojo de masías, la imposición del toque de queda o el control de las actividades y movimientos de la población) no constituyen una represión física, pero indudablemente forman parte de un entramado represivo destinado al control de la población y a impedir el

311 Gobierno Civil de Huesca a Alcaldía de Graus, 10/11/44, Archivo Municipal de Graus, Correspondencia de la Alcaldía, caja 27. 
desarrollo de actividades consideradas subversivas por el régimen. A las medidas "oficiales», además, hay que sumar los métodos concretos empleados por las fuerzas represivas para llevar a cabo las funciones de control, que incluían la violencia física, el maltrato, las amenazas. Protegidos por la legislación y dotados de un poder casi omnímodo, los responsables de guardar férreamente el orden podían entregarse a actuaciones arbitrarias con total impunidad. El ciudadano de a pie, el campesino con un pasado izquierdista que lo estigmatizaba, carecían de defensa frente a tales actitudes, puesto que estaban privados de derechos, excepto los que le eran graciosamente otorgados por autoridades benévolas o comprensivas. En realidad, las relaciones de poder, lejos de estar reguladas por la legislación, pasaron a depender fuertemente de las relaciones personales entre la autoridad y el individuo. Y pasaron, además, a estar regidas por el miedo.

Cuando se habla de represión, generalmente se alude a la más visible, la represión física; pero también hay que tener en cuenta la represión diaria que se manifestaba en coacciones continuas en el marco de la vida cotidiana. Asimismo, quienes sufrían la represión deben ser considerados en un marco más amplio. No sólo fueron víctimas de la represión los presos y presas, sometidos a condiciones infrahumanas, los antifranquistas militantes o los guerrilleros. Al igual que en la inmediata posguerra - el momento de la consolidación del régimen-, durante la época de la guerrilla la represión se extendió a amplias capas de la población bajo el pretexto de una supuesta colaboración con el movimiento armado. Personas anónimas, de antecedentes izquierdistas, pasado republicano o con lazos familiares o de otro tipo con los guerrilleros se convirtieron en objetos de represión y persecución. Extendiéndose en círculos concéntricos, como la onda de una piedra arrojada en un estanque, la represión fue alcanzando en el campo aragonés afectado por la presencia de las guerrillas a más estratos cada vez. Detenciones masivas, palizas terribles (a veces con resultado de muerte) y otras medidas fueron aplicadas, de forma casi indiscrimina$\mathrm{da}$, a hombres y mujeres de los que se sospechaba cualquier tipo de simpatía hacia los guerrilleros. Los familiares de éstos, o incluso de sus colaboradores, sufrieron también la brutalidad de los métodos de la guardia civil y los representantes del orden establecido. Ya hemos hablado de ello en el caso de Felisa Montoliu, esposa de Florencio Guillén, de Gúdar, y lo mismo ocurrió en el de Aurora Piñana, la mujer de José Mir, Cona, y en el de otras mujeres familiares de guerrilleros. 
Pero, en otras ocasiones, la represión era indiscriminada, aleatoria. Como todo régimen fascista, el franquismo utilizó el terror indiscriminado para someter y atemorizar a la población. Y a pesar del discurso ruralista del régimen, ensalzador de las virtudes campesinas, lo cierto es que el campesinado fue un estrato social especialmente maltratado por los representantes del régimen.

El terror empleado contra los campesinos se generalizó a partir de 1947 con la regularización de las contrapartidas. Se trataba, como hemos mencionado en otro lugar, de grupos de guardias disfrazados de guerrilleros, que se hacían pasar por tales y pedían comida o refugio para observar la reacción de la población, extraer información y descubrir a los apoyos y enlaces. Pero mucha de la gente que caía en la trampa de la contrapartida no tenía nada que ver con la guerrilla; actuaban movidos por el miedo o por simple caridad. Su actuación estuvo mucho más extendida en la provincia de Teruel, la más castigada por la represión antiguerrillera, pero también funcionaron en la zona de Huesca, donde, sin embargo, la policía secreta o la policía armada era aún más temida que la propia guardia civil. En Teruel se pueden recoger multitud de testimonios acerca del temor que suscitaban las contrapartidas; en ocasiones, estos grupos los formaban, además de los guardias, delincuentes comunes que se prestaban a ello para rebajar la pena, o incluso guerrilleros que se habían entregado.

Las fuerzas represivas no se limitaban a golpear o detener a los masoveros. Varios testimonios orales, y algunos documentos de la guardia civil, relatan fusilamientos colectivos de campesinos, hombres y mujeres, llevados a cabo por las fuerzas represivas. Parece que dicha práctica se utilizó en el Maestrazgo, Bajo Aragón y sur de Teruel; no hemos encontrado huella de tales medidas en Huesca o Zaragoza durante los años comprendidos entre 1944 y 1952. Ya hemos aludido a la «saca» que se produjo en la cárcel de Alcañiz, en una fecha sin determinar en torno a la primera mitad del año 1947. Y a la muerte de los cinco detenidos en Dos Torres de Mercader en octubre de 1947, a los que se aplicó la «ley de fugas», según los documentos policiales, pero que, al parecer, fueron torturados antes de morir: "los que lo enterraron lo saben. Estaban desechicos. Los habían martirizado mucho...». ${ }^{312}$ Existen otros testimonios de matanzas múlti-

312 Entrevista, L.S. Castellote, 11 de agosto de 1997. AHPT, sección Gobierno Civil, caja 1086, carpeta 84. Memoria de la Comandancia de la Guardia Civil de Teruel (1966). Centro de Estudios Históricos de la Guardia Civil. Dirección General de la Guardia Civil. 
ples, como el fusilamiento colectivo llevado a cabo el 5 de octubre de 1947 en los altos de San Rafael:

[...] Y en Montoro también hubo muchos casos... de Montoro, y de Ejulve, cogió la guardia civil mucha gente y los afusilaron en... les dieron la ley de fugas en Alcalá, porque este caminero me lo ha contado, que él ha visto un perro con... cosas humanas. En Alcalá y en el Alto de San Rafael. Se escapó creo que uno, herido, pero los mataban... dos camiones cargados de gente [...]. Y allí donde le dicen los Doce Apóstoles, allá en el Alto San Rafael, allá mataron a unos pocos. Y a los otros... sí, en eso que está de Alcalá a allá arriba, que hay un llano, los mataron a todos. Les dieron la ley de fugas... eran gente de Montoro, gente de Aliaga y los de Pitarque. Pero entre todos iban bastantes. Y de Ejulve, 28 ó 30, seguro que iban. ${ }^{313}$

Los métodos represivos empleados por la guardia civil eran los de una auténtica "contra». A una escala diferente, estas actuaciones recuerdan las de los ejércitos y fuerzas paramilitares que luchan contra las guerrillas campesinas en América Latina, y que cometen matanzas masivas entre los campesinos simpatizantes de los guerrilleros. Las muertes perpetradas en estas circunstancias son, además, imposibles de cuantificar; no ha quedado constancia de ellas en ningún registro civil, y las víctimas eran enterradas en el monte, en el mismo lugar donde morían, como se expresa muy gráficamente en el testimonio citado. Hoy día, las familias siguen sin saber dónde se hallan enterrados sus parientes.

[...] yo saqué un informe de la cárcel de Alcañiz en el cual había un traslado. $\mathrm{Y}$ era a las tantas horas de la madrugada. Incluso el informe lo decía eso. Yo me interesé por eso porque había uno que estaba en nuestra casa, que... toda la vida se tiró allí porque era mi padre albañil, aprendiz de albañil, y estaba con él y eso. Y nos interesaba por eso, a ver si podíamos conseguir una partida de defunción porque claro, esa mujer [la mujer del albañil desaparecido] ni se ha quedado viuda, ni se ha podido volver a casar, ni ha tenido pensión. Pues no hemos podido jamás $[\ldots]^{314}$

Una conclusión significativa que podemos extraer del estudio de la represión relacionada con la guerrilla en Aragón es que ésta se dirigió de forma muy notable hacia los pobladores de la zona, y que no se detuvo ante casos de autoridades laxas o que no manifestaron la suficiente firme-

313 Entrevista, informante anónimo (hombre de 68 años). Rubielos de Mora, 1 de agosto de 1999. Realizada en colaboración con José Giménez Corbatón.

314 Entrevista, P.Z. Aguaviva, 6 de agosto de 1996. 
za en el desempeño de sus cargos. Esta postura fue adoptada sobre todo en Teruel, como resultado de la inflexible política antiguerrillera llevada a cabo por el general Pizarro. A partir de febrero de 1947, varias autoridades locales sufrieron los rigores de esta política: entre ellos, el alcalde de Foz-Calanda, Julián Borraz, detenido en diciembre de 1947, tras el asalto de un grupo de guerrilleros a la localidad, por no haber dado parte hasta transcurridas 24 horas, plazo que le había sido ordenado por los guerrilleros; y el alcalde de El Colladico, Jerónimo Planas, detenido en junio de 1949 tras ser asaltado por un grupo de guerrilleros, por no denunciar el hecho «hasta transcurridas 26 horas y tras reunir al ayuntamiento para ver si procedía o no dar cuenta». También se recoge en la documentación el caso del jefe local de Falange de El Pobo, que, tras la muerte a manos de guerrilleros de un vecino de esta localidad en agosto de 1947, no tomó ninguna medida para su persecución, por lo que fue acusado por el gobernador civil Manuel Pizarro de «actuación cobarde» y «falta de valor cívico", aunque no queda constancia de que se tomaran medidas concretas contra él. También de agosto de 1947 datan las detenciones de dos serenos desarmados por guerrilleros, que fueron detenidos por no dar cuenta inmediatamente, con lo que "son incursos en el art. 8. ${ }^{\circ}$ apdo. C del Decreto-Ley del 18 de abril de 1947 sobre represión del bandolerismo». Añadiremos que tales casos son reflejo de la dureza de la represión, pero también del miedo que llegaron a provocar los guerrilleros entre algunas autoridades locales, que no dudaban en cumplir las indicaciones que recibían de éstos ante el temor a represalias; represalias que, por cierto, ocasionaron la muerte de varios alcaldes, como el de Villar del Cobo o el de El Cuervo, ambos durante el año $1947 .{ }^{315}$

Podemos observar que la conflictividad en general, así como las dimensiones de la represión, alcanzaron niveles muy diferentes en las provincias de Huesca y de Teruel. Como ya hemos tenido ocasión de señalar en varias ocasiones, la actividad guerrillera en Teruel fue muy superior a la de Huesca, exceptuando la época de las «invasiones» a través de los Pirineos, que implicaron un gran despliegue militar en la zona. Por tanto, esta superior actividad guerrillera trajo consigo una represión proporcionalmente

315 Toda la documentación procede del AHPT, sección Gobierno Civil. El alcalde de Foz-Calanda, en caja 1085, carpeta 9, y caja 1130, carpeta 33; el alcalde de El Colladico, en caja 1986, carpeta 91; y el jefe local de FE de El Pobo, en caja 1086, carpeta 49. 
más dura. Además, hemos de señalar la existencia de un gran responsable, a nivel individual, de la represión sufrida en la provincia turolense: se trata del general de la cuardia civil Manuel Pizarro Cenjor, al que ya hemos nombrado profusamente. Pizarro acumuló varios cargos civiles y militares en su persona: gobernador civil y militar de Teruel, y jefe de la 5. ${ }^{a}$ Región de la Guardia Civil, puestos que ocupó hasta su muerte en 1953. Pizarro concentró, pues, un poder casi omnímodo, y de esta concentración de poder depositado en sus manos por el régimen franquista deducimos que el dictador puso en él su confianza para terminar de una vez por todas con la amenaza guerrillera en la región aragonesa y la desestabilización que provocaba. El general Pizarro, veterano de la lucha antiguerrillera en las provincias de Granada y León, donde al parecer logró notables éxitos, forma parte de una generación de jefes del cuerpo caracterizados por su dureza de actuacion y su ambición, y que encontraron en la lucha antiguerrillera (o «contra el bandolerismo", según la terminología del régimen) el mejor cauce para lograr ascensos y prestigio de modo rápido. En este grupo de mandos que se pusieron al frente de la lucha antiguerrillera en 1947, coincidiendo con la promulgación del Decreto-Ley contra el Bandidaje y el Terrorismo, podemos incluir también al teniente coronel Eulogio Limia Pérez, en Ciudad Real, el capitán Sánchez Montoya, en Alcázar de San Juan, o el teniente coronel Luis Marzal, en Jaén.

Pizarro fue el responsable directo de la táctica de dirigir la represión contra la población como medio para minar los apoyos sociales de la guerrilla, y también de la actitud despiadada de las fuerzas represivas durante los años comprendidos entre 1947 y 1952 . Además, fue el responsable de la militarización de la provincia de Teruel y especialmente de la zona del Maestrazgo, donde, además de construirse cuartelillos de la guardia civil en casi todas las poblaciones que aún carecían de ellos, se instaló una «columna volante» en Mas de las Matas, un regimiento de artillería de montaña en Morella y una bandera del Tercio en Valderrobres. Pizarro convirtió la provincia de Teruel en una enorme ratonera y la lucha contra la guerrilla en una guerra contra la población civil, una guerra sucia en la que todo (el engaño, la traición, el chantaje) estaba permitido.

La represión contra la guerrilla, por lo tanto, perseguía un objetivo más amplio. Era una represión dirigida al control férreo de la sociedad campesina, y que partía del supuesto de que la guerrilla era una emanación de esta sociedad campesina y de ella extraía sus efectivos y apoyos, lo que era 
cierto. La represión se encaminó, pues, a eliminar la capacidad de acción demostrada por este campesinado «rebelde», atacando, si era necesario, sus formas tradicionales de vida, paralizándolo por el terror y no deteniéndose ante la tortura, el encarcelamiento o incluso la eliminación de mujeres, de menores o de familias enteras. La sociedad campesina reaccionó contra esta represión en la medida de lo posible, en especial en Teruel, organizándose en colaboración con la guerrilla o al margen de ésta para defenderse y defender sus métodos tradicionales de vida. Pero la represión pronto sería demasiado fuerte y, sobre todo, adoptaría la forma de lo imprevisto, superando todas las previsiones de los campesinos e incluso sus peores pesadillas. El miedo, finalmente, demostró ser la mejor arma contra la guerrilla. Además, esta represión eliminó de una forma o de otra a los partidarios de la guerrilla, y al final sólo quedaron en las zonas guerrilleras individuos hostiles o indiferentes. Sin minusvalorar las enormes pérdidas que sufrieron las fuerzas guerrilleras a manos de sus enemigos, la enajenación de los apoyos con los que contaban en el seno de la población campesina fue el castigo más eficaz que pudo infligirles el régimen franquista.

\subsection{Las relaciones entre la guerrilla y la sociedad rural aragonesa}

\subsubsection{Los posicionamientos del campesinado}

En un capítulo anterior describíamos la situación del campesinado aragonés en torno a 1940, así como los conflictos que se iban perfilando en la sociedad rural aragonesa. Una sociedad duramente castigada por la represión de posguerra, y sembrada de conflictos larvados que iban a resurgir con fuerza cuando la aparición del movimiento guerrillero introdujese en el panorama un nuevo factor de inestabilidad.

Es evidente que la guerrilla no contó con el apoyo de todos los sectores del campesinado. Las simpatías de éste se hallaban divididas: unos apoyaban a la guerrilla; otros deseaban su eliminación y estaban dispuestos incluso a colaborar con las fuerzas represivas para conseguirla, como hicieron los que formaron parte de los somatenes. Y, en medio de ambos grupos, estaba la gran masa de quienes no se decantaron a un lado ni al otro, aunque la guerrilla, así como el proceso represivo que generó, fue un elemento tan visible y desestabilizador que nadie pudo permanecer indife- 
rente frente a él. La guerrilla, pues, fue un nuevo elemento de ruptura en una sociedad que ya estaba fragmentada por los conflictos que había generado la guerra civil y aquellos, más antiguos, que la guerra no había solucionado sino que contribuyó a agravar. La nueva delimitación de estos conflictos es compleja. Una vez resuelta la crisis de los años treinta con la salida fascista que se consolidó definitivamente en 1939, ¿cómo se trazan las nuevas líneas de fractura? La identificación de los sectores del campesinado que se alinearon a favor o en contra de la guerrilla es el mejor indicador de esta política de «bandos» que se desarrolló de forma soterrada en el mundo rural aragonés, en un momento en el que no era posible mostrar abiertamente ningún tipo de disensión frente al régimen, y menos en el mundo rural, donde, como indica Hartmut Heine, la represión se acentuaba por la ausencia de anonimato, que dificultaba enormemente la reconstrucción de las organizaciones de izquierdas. ${ }^{316}$

La conflictividad se distribuyó también de forma irregular desde un punto de vista geográfico. Existían focos de inestabilidad y territorios donde se vivió una relativa calma. Además, como ya apuntábamos anteriormente, podemos trazar una "geografía de la conflictividad" bastante estable durante los años treinta y cuarenta en el territorio aragonés. Grosso modo, la línea del frente de Aragón hasta 1938 marcaría la frontera de este territorio de conflictividad, que comprendería las zonas que se encuentran al Este, es decir, aquellas en las que se llevó a cabo la experiencia revolucionaria y colectivizadora durante la guerra. El hecho de que la guerrilla arraigase posteriormente de forma notable en estas mismas zonas hace que nos planteemos como hipótesis el hecho de que la experiencia de la domi-

316 Heine hace esta observación en relación con la reconstrucción del Movimiento Libertario, y añade que «la región de Aragón [...] a pesar de haber contado en el pasado con una gran tradición y militancia libertaria, desempeñaría en el proceso reorganizativo un papel más bien secundario». Como hemos visto, no es que esta tradición libertaria desapareciese, sino que se canalizó en la participación en el movimiento guerrillero organizado por el PCE. Heine llega a la conclusión de que, a la larga, la participación en la guerrilla repercutiría negativamente en la recuperación de la CNT y las Juventudes Libertarias, lo que podemos considerar cierto si pensamos en la represión que se desató contra la guerrilla, que afectaría a gran parte de la población civil, y en el hecho de que la organización comunista de la guerrilla abortó cualquier intento de reagrupación de los libertarios en el seno de ésta. Hartmut Heine: «Algunos determinantes del resurgimiento y desarrollo del movimieto libertario durante los años cuarenta», en La oposición libertaria..., op. cit., pp. 17-30, cita en p. 18. 
nación republicana fuera percibida por un sector de la población de forma positiva, y quef, por el contrario, la «reconquista» por parte de las fuerzas franquistas se viviese como un proceso traumático, lo que daría lugar a la existencia de una actitud larvada de oposición que se manifestaría a partir de la implantación de la guerrilla.

Por tanto, las mismas zonas donde se produjeron colectivizaciones fueron el escenario de actuación de la guerrilla, siempre y cuando fuesen montañosas, razón por la cual la franja de la provincia de Zaragoza comprendida en esta zona quedó sólo como lugar de paso. En dicha provincia, el único núcleo guerrillero se encontraba en la otra franja, en la comarca de las Cinco Villas, y coincidía con un importante núcleo de conflictividad obrera y campesina durante la República, además de ser la única zona en la que hubo «huidos» en los primeros momentos de la sublevación militar. En este territorio tradicionalmente conflictivo destaca la sierra del Maestrazgo, escenario de movilizaciones campesinas desde las guerras carlistas.

Además del pasado de movilización obrera y campesina, que tiene un indudable peso en el posterior arraigo del movimiento guerrillero, es necesario otro factor para que se produzca este arraigo, un factor evidente: la instalación de un núcleo o campamento guerrillero. A su vez, tal instalación está condicionada, como ya veíamos anteriormente, por la procedencia de los jefes de grupos guerrilleros, que manifestaron una fuerte tendencia a instalarse cerca de sus lugares de origen. Con ello aprovechaban su conocimiento de la zona y se beneficiaban de la cercanía de familiares y vecinos, a los que podían implicar en las redes de resistencia que la guerrilla puso en pie en todos los lugares donde se instaló y que eran imprescindibles para su supervivencia, puesto que los habitantes de la zona eran los que proporcionaban a los guerrilleros suministros de ropa y comida, lugares donde ocultarse o curar a los heridos e información sobre el movimiento de las fuerzas represivas o las características de los vecinos, es decir, cuáles eran de fiar y cuáles no.

Por otra parte, la influencia de la guerrilla en la sociedad campesina aragonesa tampoco era homogénea entre los territorios guerrilleros. Existen importantes diferencias entre el impacto que tuvo en el Alto Aragón y el que observamos en la provincia de Teruel. En Huesca, tanto las adhesiones como los rechazos estaban matizados por el hecho de que los enfrentamientos no habían sido tradicionalmente tan virulentos como en 
Teruel. Probablemente, ello se debe a varios factores entre los que quizás podamos incluir un reparto algo más equilibrado de la propiedad de la tierra, ya que, a pesar de la existencia de un núcleo importante de propietarios absentistas, las diferencias entre el resto de propietarios no eran tan marcada como en Teruel, donde la abundancia de ínfimos propietarios provocaba que muchos de ellos tuviesen que trabajar por cuenta ajena para sobrevivir. Asimismo, la provincia altoaragonesa tuvo un grado de conflictividad menor durante la República, directamente relacionado con lo anterior. Y, por último, el factor más significativo: la incidencia relativamente menor de la represión franquista sobre el campesinado. En Huesca, la represión durante la guerra civil estuvo más bien dirigida hacia el clero en la zona republicana, y hacia miembros de la clase obrera y la pequeña burguesía urbana y liberal en la zona franquista; no en vano, los partidos judiciales más castigados por la represión franquista fueron los de Huesca y Jaca (donde se encuentran los núcleos urbanos más importantes de la provincia), ambos con más de trescientos asesinados, muy por encima del resto. ${ }^{317}$ No obstante, también fue muy importante la represión dirigida contra los campesinos sindicados, principalmente, en la FNTT, el sindicato rural de clase con más implantación en la zona occidental de la provincia. Pero el campesinado, dentro de lo que cabe, resultó menos afectado por la represión que en Teruel, donde constituye el colectivo más castigado por la represión franquista: un $55 \%$ del total de represaliados, si consideramos dentro de esta categoría a labradores y jornaleros. ${ }^{318}$

Lo cierto es que en Huesca el avance de las tropas franquistas en el frente de Aragón a partir de la primavera de 1938 no resultó tan brutal como en Teruel, probablemente debido a la proximidad de la frontera, que hizo que muchos altoaragoneses de izquierdas alcanzaran el país vecino y escapasen así a la represión. Por el contrario, los turolenses que lograron huir hacia Levante quedaron atrapados en la inmensa trampa del puerto de Alicante, o bien se vieron forzados a volver a sus lugares de origen al

317 Julián Casanova y otros, El pasado oculto..., op. cit., p. 242. En el caso de Jaca, también influyó sin duda en el alto número de represaliados el episodio del levantamiento republicano de diciembre de 1930 y el hecho de que esta ciudad fuese considerada «cuna de la República».

318 Ángela Cenarro, «El triunfo de la reacción: fascistas y conservadores en Teruel», en Julián Casanova y otros, El pasado oculto. Fascismo y violencia en Aragón (1936-1939). Mira, Zaragoza, 1999, p. 191. 
final de la contienda, sin imaginar la represión que iba a descargarse sobre ellos, orquestada, en muchas ocasiones, por sus propios vecinos. A esta diferencia en cuanto al nivel de violencia experimentado durante la posguerra en una y otra provincia achacamos, en parte, el distinto grado de conflictividad vivido durante los «años de los maquis». Y, por otra parte, el distinto grado de violencia estuvo condicionado, como se ha repetido numerosas veces a lo largo de estas páginas, por las diferentes características y modos de actuación de los dos grupos guerrilleros que se instalaron en terrritorio aragonés.

Como ya ha quedado sobradamente de manifiesto, el sur de la provincia de Teruel fue la zona en la que la guerrilla tuvo una influencia más notable. Ello es debido a la combatividad de la AGLA, pero también al grado de adhesión que ésta consiguió despertar entre el campesinado turolense, especialmente en los pequeños núcleos del Maestrazgo y las sierras de Gúdar y Javalambre, zonas caracterizadas por un poblamiento disperso, una economía muy pobre, casi de subsistencia en algunos sectores, y una convivencia social muy alterada por los acontecimientos vividos durante la guerra y la posguerra. Había núcleos, como Mosqueruela, Aguaviva o La Ginebrosa, en los que una parte mayoritaria de la población estaba implicada en la ayuda a la guerrilla. En La Ginebrosa (de donde procedía un guerrillero del $17 .^{\circ}$ sector, Joaquín Boj) una informante nos relata la reacción de la población ante la detención en 1947 de un maestro relacionado con la guerrilla: «[...] y decían, decían: “¡Ay, si hubiese declarado el maestro! ¡Toda La Ginebrosa hubiera volado!””. Lo cual es muy expresivo del alto grado de implicación de la población en la colaboración con la guerrilla. ${ }^{319}$

En Teruel se dio además un fenómeno que no se produjo apenas en la provincia de Huesca: la incorporación a las filas guerrilleras de numerosas personas naturales de la zona. Muchas de estas personas tenían un pasado de militancia política durante la guerra, frecuentemente en las filas de

319 Entrevista, informante anónima. La Ginebrosa, 12 de noviembre de 1996. AHPT, sección Gobierno Civil, caja 1086, carpeta 47.

Este maestro era Valentín Santapau, conocido como «el maestro de las Masadetas», que daba clases a los hijos de los masoveros de La Ginebrosa y a la vez era enlace de la guerrilla. Fue detenido y conducido a Alcañiz, donde al parecer intentó suicidarse; Ferrán Sánchez afirma que se le aplicó la «ley de fugas» en Alcañiz el 15 de noviembre de 1947. Maquis a Catalunya..., op. cit., p. 231. 
la CNT, y, como José Vicente Zafón, Pepito de Mosqueruela, habían tomado parte activa en las colectividades. En los sectores $11 .^{\circ}, 17 .^{\circ}$ y $23 .^{\circ}$ encontramos a muchos de estos "guerrilleros autóctonos». En algunos casos, como el del propio Pepito de Mosqueruela, habían entrado a formar parte de las redes de apoyo y abastecimiento organizadas por los guerrilleros. En otros casos se trataba de "topos», como Bernabé Rovira, Garrobe$r a$, de Mosqueruela, o de libertos condicionales que vivían más o menos escondidos en sus masías, como Miguel Serrano Iranzo y su famoso hermano Francisco, que durante una temporada llegó a ser jefe del $17 .^{\circ}$ sector. También Manuel Pérez Cubero, Rubio, guerrillero muy próximo a la dirección de la AGLA (cuya militancia comunista es anterior al establecimiento de la guerrilla, y que ejercía inicialmente funciones de enlace), vivía en la provincia de Teruel, y sus padres residían en la estación de Rubielos de Mora. Su madre, Asunción Cubero, efectuaba el enlace de la guerrilla con Valencia y Teruel, y ambos, padre y madre, fueron duarmente represaliados por la guardia civil. También contamos entre estos guerrilleros a los Florencio Guillén, padre e hijo, los protagonistas de la matanza de Gúdar, y a Domingo Durbán, Ceferino o Viriato, de El Cuervo, hijo de unos pequeños comerciantes de la localidad represaliados por su ideología izquierdista tras la guerra y que finalizaron por abandonar la localidad a principios de julio de 1947, rumbo a un lugar desconocido, mientras su hijo se incorporaba a la guerrilla.

La historia de la familia Durbán proporciona una nítida visión de la situación de estos sectores represaliados y sus condiciones de vida durante la posguerra. Poseían un comercio en El Cuervo, que les fue incautado, y al parecer habían contraído numerosas deudas con entidades bancarias. El informe policial afirma que la familia huyó del pueblo «porque temía ser linchada» por sus acreedores; en esos momentos el hijo, Domingo, ya se encontraba en la guerrilla. Sin embargo, en otro informe descubrimos que la familia Durbán iba a ser detenida por su posible connivencia con los guerrilleros, después de que las autoridades locales, concretamente el alcalde y el juez, recibiesen amenazas de muerte en el caso de que se detuviese a algún vecino de izquierdas, firmadas por los guerrilleros de Levante, versión que parece más acorde con la realidad. Por lo tanto, en este episodio queda reflejada, por una parte, la manipulación de la realidad llevada a cabo por los informes oficiales, y, por otra, la forma en que, en los acontecimientos relacionados con la guerrilla, se entremezclaban las redes per- 
sonales y familiares que unían a los individuos en cada localidad. Es evidente que los bandos o facciones estaban perfectamente delimitados. Por un lado, están las autoridades locales, alcalde y juez, que contaban con el apoyo del aparato represivo del Estado y que constituían la elite política de la localidad, en la que ejercían una represión tanto económica como política sobre los vecinos de pasado izquierdista. Y por otro lado, se encuentran estos vecinos de izquierdas, conectados entre sí y con la guerrilla por redes informales que no tenían por qué materializarse en la militancia clandestina en un partido o sindicato. De hecho, Domingo Durbán no ingresó en el PCE hasta después de su incorporación a la guerrilla, cosa que, por lo demás, sucedía con muchas de las personas que se incorporaban de esta forma. Por lo tanto, más que a la militancia, casi inexistente, debemos atender a las actitudes y a las relaciones que estas personas izquierdistas mantenían entre sí para delimitar los grupos que se definían en cada localidad. Las autoridades prestaban una gran atención a estas actitudes y relaciones. En el informe que da cuenta de la desaparición de la madre y la tía del guerrillero (pues el padre había huido antes) se especifica que «ambas señoras observaban buena conducta aunque simpatizaban con elementos de izquierda». Fueron finalmente estas "simpatías», y no la «buena conducta», las que primaron en la consideración de la familia Durbán por parte de las autoridades. ${ }^{320}$

Por consiguiente, podemos establecer una tipología que definiría a un importante sector de los colaboradores de la guerrilla como izquierdistas locales que habían sido represaliados tras la entrada de las tropas nacionales y que vivían en una situación opresiva, sometidos a una sutil (o no tan sutil) represión cotidiana. Este sector, en la medida en que logró contactar con la guerrilla, se comprometió fácilmente con ella, siempre y cuando la represión vivida no hubiese sido tan brutal que anulase su capacidad de reacción y su voluntad de resistencia. De este modo, por ejemplo, José Aguilar, miembro de una familia republicana de Aguaviva (cuyo padre era alguacil del Centro Republicano y posteriormente moriría a manos de la guardia civil) se implicó, casi sin darse cuenta, en las redes de suministros organizadas por el grupo de Antonio cuando mantenía su base de Aguaviva y coordinadas por José Mir, el Cona. Era minero, otro de los grupos,

320 AHPT, sección Gobierno Civil, caja 1085, carpetas 75 y 80. 
junto con los campesinos y los ferroviarios, que han tenido una importante presencia en la guerrilla, tanto en calidad de guerrilleros como en las estructuras clandestinas organizadas por ellos:

Y claro, pues yo, trabajaba en las minas de Castellote. Nos poníamos a las cinco de la mañana, y yo tenía dos horas de camino hasta las minas. Ocho kilómetros. Y yo me tenía que levantar a las tres de la mañana. Y a la que llegaba al pantano de Santolea, bueno, pues allí, nada más cruzar el pantano, era casi diario que me encontraba con ellos. Y con la guardia civil. Yo temía a la guardia civil, a ellos no les tenía miedo, porque si parábamos, cuando nos juntábamos, nos echábamos un cigarro, si nos sobraba algo de café o les sobraba a ellos, porque yo tenía ocasión de comprar más que ellos [...] y después ya bajábamos aquí y estábamos en contacto con los campamentos que tenían aquí al término de La Cerollera. Y claro, nosotros llevábamos allá, mi padre les había llevado, pero vamos, él no sabía para quién era, porque mi padre no estaba tan enterado. Y había ido con cargas de... que cargaban huevos y lo que fuera, y lo llevaban a una masía que le llamaban el Mas de Mataví. Y allí iban a recogerlo ellos $\left[\ldots . .^{321}\right.$

Un elemento sumamente importante es la forma en que las relaciones familiares condicionaban el compromiso con la guerrilla. No podemos asegurar que en todos los casos se tratase de un compromiso de carácter político. Cuando las madres, los hermanos o los tíos de uno de estos guerrilleros colaboraban con él, estaban siendo fieles, en primera instancia, al vínculo familiar y las obligaciones que conlleva; sobre todo, en el caso de las madres, a las que vemos muchas veces implicadas de forma muy comprometida en la colaboración con la guerrilla, y siendo víctimas, frecuentemente, de la represión oficial. Ello no significa, forzosamente, que tales acciones estén desprovistas de contenido político. Es más, observamos con frecuencia cómo, en el mundo rural del «Teruel profundo", donde los canales de comunicación con el exterior no eran muy abundantes, el medio familiar era el principal medio de transmisión de las ideologías políticas, a menudo entendidas de forma muy elemental, como alineamientos «de izquierdas» o "de derechas». Muy elemental, pero a la vez muy explícita para los protagonistas: en una localidad determinada, todo el mundo sabía qué familias eran de izquierdas y cuáles de derechas, y también tenía muy claras las implicaciones de dicho alineamiento.

321 Entrevista, J.A. Aguaviva, 13 de abril de 1997. 
El posicionamiento ideológico no coincidía necesariamente con la situación económica, sino con las redes entretejidas entre los habitantes de la localidad. Un pastor o un masovero podían participar de la ideología conservadora de su amo, a pesar de ser muy pobres, y un juez simpatizar con posiciones de izquierdas. ${ }^{322}$ En palabras de Javier Ugarte, que también señala que en el mundo rural navarro y vasco la socialización política introducida por la República cristalizó en dos bloques, las «derechas» y las «izquierdas», "no eran las ideas ni la opción individual las que daban forma al grupo (situación que corresponde a sociedades en las que el hombre es consciente de su individualidad y alega adscripciones diversas, el tipo ideal de sociedad liberal). Eran más bien los vínculos personales — que implicaban intereses concretos, rencillas, en ocasiones familiares, amistades, patronazgo, etc. — los que venían a dar una primera forma a los bloques». ${ }^{323}$

Ugarte está describiendo la situación anterior a la guerra civil. Durante ésta, y también a lo largo de la posguerra, los bloques se solidificaron de una forma radical, y, sobre todo, se abrió entre ellos un abismo que la presencia de la guerrilla no hizo sino agrandar. Lo que provocó ese abismo fue la violencia vivida durante la guerra y la inmediata posguerra, una violencia que en las comunidades rurales tenía nombre y apellidos. Un hombre podía vivir pared con pared con el vecino al que denunció y a cuyo padre hizo fusilar, o una mujer encontrarse todos los días en la plaza con las vecinas que le cortaron el pelo al rape. Sin embargo, la propia represión de posguerra introdujo un nuevo elemento en la delimitación de las alineaciones políticas, que en ocasiones vino a romper tanto la tradición política familiar como las lealtades derivadas de vínculos personales de las que habla Ugarte: ese elemento es el miedo. Un miedo que cristalizó en significativos "cambios de bando» que a veces traicionaban arraigadas trayectorias familiares de izquierdas, como se desprende de varios testimonios orales:

[Hablando de José Mir, el Cona, guerrillero de Aguaviva]. A mí me preguntaba: «¡Y Fulano, que era tan bueno?». Y yo: «Ha fallado». «¡Mecagüen diez! Si su padre era tan bueno, tan buen republicano...» "Pues él ya no es como su

322 Como en el caso del juez de paz de Mosqueruela, Urbano Zaera Monforte, detenido en julio de 1949 "por hallarse complicado en protección y auxilio a los bandoleros». AHPT, sección Gobierno Civil, caja 1086, carpeta 106.

323 Javier Ugarte, La nueva Covadonga..., op. cit., p. 15. 
padre.» «Pero ¿cómo es eso?» Y yo: «Chiquet, mira, las cosas... el terror amansa mucho.»

[...] Y aún hubo dos o tres que se apuntaron a Falange, ¿eh? Hubo dos o tres que se apuntaron. De aquí del pueblo. [...] Eran de izquierdas los padres de todos, y cogieron miedo y se apuntaron a Falange. ${ }^{324}$

Las acciones de la guerrilla son totalmente coherentes con la existencia de los dos bloques que hemos descrito: se instaló en el territorio en connivencia con uno de ellos y atacó al otro, en el que veía la encarnación próxima e inmediata del régimen que había venido a combatir. Ésta es una de las razones de la duración de la guerrilla turolense, de su implantación y de su virulencia: que vino a encajar sobre un panorama ya convulso y unas fracturas ya delimitadas. Como señalábamos en otro capítulo, la organización de la guerrilla comunista se encontró con la existencia de unas embrionarias formas de organización entre los campesinos, con algunos grupúsculos armados en los montes y, sobre todo, con la predisposición de un sector importante de la población a ayudar a los guerrilleros y colaborar con ellos. Y, del mismo modo, encontraron a otro sector de la población dispuesto a combatirlos por todos los medios. Probablemente, el sector de la población dispuesto a luchar de forma efectiva contra la guerrilla era minoritario, pero era el que detentaba el poder.

Sin embargo, la idea de un conflicto puramente ideológico o de clase es ajena, en general, a la mentalidad campesina. Como hemos repetido en más de una ocasión, el pensamiento campesino es concreto, factual, basado en la experiencia y en la observación de la realidad. En los testimonios de los campesions no podemos pretender encontrar un análisis en clave política de los acontecimientos. Ellos relatan lo que veían, y la forma en la que observaban que se canalizaban los conflictos. Y en el fondo, frecuentemente, se encuentra el problema de la tierra. Un problema omnipresente para el campesino. Cuando se le pregunta a un informante si cree que las ideas influyeron en los conflictos, su respuesta vuelve casi inconscientemente al tema de la tierra, que es como un Leitmotiv del discurso campesino. En muchos casos, la tierra se mezcló con la política, y la guerrilla proporcionó el marco para solucionar ambos conflictos, material e ideológico, de forma violenta.

324 Entrevista, A.B. Aguaviva, 6 de agosto de 1996. Entrevista, J.A. Aguaviva, 13 de abril de 1997. 
Yo creo que por ideas [silencio]... ay, y hasta incluso por la partición de una finca o de una casa. Hasta por ahí podía haber rencillas: "ahora que tengo yo la sartén por el mango, ahora me la vas a pagar, que me hiciste partir por aquí o me hiciste partir por allá». Hasta de esas cosas podían llegar. Porque yo creo que la gente antes teníamos mucha menos cultura para esas cosas que se tiene ahora. Y aun teniendo más cultura aún hay rencillas, conque, cuando no había, pues imagínate si había. ${ }^{325}$

Por lo tanto, en el fondo, desde el punto de vista del campesinado, está el problema de la tierra y de la gestión de los recursos. El mismo problema que generó la conflictividad campesina de la Segunda República y toda la problemática de las colectividades. Así pues, hay continuidad con las cuestiones que preocupaban al campesinado aragonés desde la década de 1930.

Sin embargo, la disputa sobre la propiedad de la tierra tenía unos matices muy diferentes de los que presentó en las zonas latifundistas del sur de España. En Aragón existía también un núcleo de propietarios absentistas, principalmente en las provincias de Zaragoza y Huesca (en los partidos judiciales de Zaragoza, La Almunia, Pina, Fraga y Huesca). En Teruel, el índice de tierras en régimen de aparcería era mucho mayor (un $15 \%$ de las explotaciones, según el Censo Agrario de 1962). Las zonas con mayor concentración de la riqueza rústica no participaron de la problemática guerrillera, y, por tanto, es difícil establecer una relación directa entre el régimen de tenencia de la tierra y la conflictividad de los años cuarenta. Cuando nos referimos a la tierra como factor de conflicto, aludimos más bien a enfrentamientos particulares entre individuos, acentuados, por supuesto, en aquellas zonas en las que el acceso a la propiedad de la tierra era más problemático. En este sentido, sí podríamos relacionar la conflictividad turolense de posguerra con esos altos índices de tenencia indirecta de tierras. Pero la problemática de los campesinos, después de la guerra civil, se centraba más bien en los conflictos a pequeña escala. No existían masas de jornaleros explotados por grandes propietarios latifundistas, como en el sur, sino un panorama muy parcelado de medianos, pequeños e ínfimos propietarios, de medieros y aparceros, enfrentados por problemas relacionados con la inmediata supervivencia o la defensa de sus intereses particulares, como el agua de riego o las lindes de las fincas. El gran

325 Entrevista, J.B. Cañada de Benatanchuz, 26 de julio de 1997. 
expoliador en el medio rural aragonés durante los años cuarenta era, en realidad, el Estado franquista, con su política de cupos, que forzaba a los pequeños e ínfimos campesinos a desprenderse de recursos que en ocasiones precisaban para su supervivencia. No hay que olvidar que una de las manifestaciones más duraderas y generalizadas de la política del régimen franquista en el campo, dejando al margen el problema de la guerrilla, fue el control de la producción agrícola y el mantenimiento de un sistema de autarquía y racionamiento que contribuyó de forma importante a la sensación de empobrecimiento y expolio que sufría la población. Una de las formas de rebeldía frente a tal situación fue, ya lo hemos visto, el pequeño estraperlo, y, relacionada con él, la «insumisión fiscal» ejercida por muchos de estos campesinos. No se trataba tanto de conflictos en torno a la propiedad de la tierra como de conflictos centrados en el control sobre la gestión de los recursos. De todas formas, creemos que la conflictividad vivida de forma contemporánea a la presencia de la guerrilla y que constituyó su caldo de cultivo, principalmente en Teruel, estaba relacionada, sobre todo, con las fracturas y los traumas sufridos a raíz de la guerra civil y durante la represión posterior. Fueron las actitudes de cada uno de los actores sociales en aquellos acontecimientos las que se repitieron fielmente a partir de 1944. Por consiguiente, coincidimos con Julián Casanova cuando afirma que "en la práctica se comprueba que los conflictos no siempre surgen como respuesta a los problemas existentes, ni es del todo exacto que la desigual distribución de la riqueza sea la que origine conflictos más graves». ${ }^{326}$ Creemos que, al hablar de "problemática campesina", o de los conflictos en torno a la tierra y su aprovechamiento, hay que ir más allá del mero estudio de las grandes estructuras macroeconómicas e indagar el significado que el problema de la tierra tenía para los campesinos en su vida cotidiana.

En cierto modo, los guerrilleros fueron conscientes de la importancia de la tierra y del control sobre la gestión de los recursos para los campesinos. Las protestas relacionadas con la política de tasas, los enfrentamientos con los inspectores de Abastos o las actitudes campesinas de insumi-

326 Julián Casanova, Anarquismo y revolución..., op. cit., p. 50. Los datos acerca de la estructura de la propiedad de la tierra en Aragón, en Luis Germán, Aragón en la Segunda República. Estructura económica y comportamiento político. Institución Fernando el Católico, Zaragoza, 1984. 
sión fiscal fueron recogidas, difundidas y alentadas por la prensa comunista distribuida o elaborada por los guerrilleros. Ya hemos comentado el choque de mentalidades que se produjo entre el discurso fuertemente politizado de los guerrilleros comunistas y el mundo mental campesino. Quizá para corregir esto, el problema de la represión económica ocupó un lugar muy importante en la propaganda que los guerrilleros hacían llegar al campesinado.

En el periódico de la AGLA El Guerrillero, el campesinado y su problemática es un tema constante. En los nueve número que se han conservado de esta publicación, los artículos dedicados específicamente al campesinado representan más de un $6 \%$ del total de artículos, editoriales, noticias, llamamientos, consignas y partes guerrilleros publicados. Ya en su primer número, de noviembre de 1946, El Guerrillero hacía un llamamiento explícito a los campesinos, no para que se uniesen a los guerrilleros o para que apoyasen su lucha sino para que se rebelasen contra la política económica del régimen. La relación entre campesinado y guerrilla era presentada a la inversa: serían los guerrilleros quienes apoyarían a los campesinos en esa lucha contra la política económica franquista.

CAMPESINOS: El régimen actual en el que vivimos es el único causante de nuestra desgracia y sufrimientos y de la ruina en que está sumida nuestra Nación; por su culpa hubo en España un millón de muertos, a quienes sus madres lloran toda la vida y es responsable que miles de sus hijos no estén junto a sus familiares.

Por eso, a vosotros, que también sois víctimas inocentes de los verdugos franquistas, os exhortamos a que luchéis contra este régimen de oprobio que nos envilece y nos niega el derecho a la libertad, la cual conquistaremos, a base de nuestro sacrificio.

¡Luchad por ser dueños de vuestras cosechas! ¡Contra el cupo forzoso, por el mercado libre y por una vida más digna y humana!

Tenéis a vuestro lado a los guerrilleros de Levante que en todo momento arma en brazo, os defenderán contra los ladrones falangistas y fiscalías de tasas. ¡Campesinos, unidos y adelante!

¡Viva el gobierno del Dr. Giral! ¡Viva la República! ${ }^{327}$

La defensa por parte de los guerrilleros de los intereses del campesinado más pobre no se limitó al ámbito del discurso, pero realmente las accio-

327 El Guerrillero. Órgano de la Agrupación Guerrillera de Levante, n. ${ }^{\circ}$ 1, noviembre de 1946. 
nes concretas realizadas por ellos no fueron muy abundantes, aunque se registran varios ataques a recaudadores de la contribución o a inspectores de Abastos. Un caso interesante de identificación con un problema concreto de los campesinos se produjo en Andorra por parte de dos guerrilleros que en 1945 quedaron aislados del resto de sus compañeros y permanecieron en la zona durante un año. Los guerrilleros amenazaron a un guardia jurado de la localidad de Híjar, destacado derechista, porque «no dejaba a los masoveros de Andorra hacer leña en el pinar de Híjar». Con lo cual, más allá de las consignas abstractas contra los «fiscaleros» o los «ladrones de Abastos», se planteaba un problema concreto relacionado con la utilización y aprovechamiento del monte comunal. ${ }^{328}$ Quizá una de las acciones más explícitas fue el asesinato de un transportista de Graus que denunciaba el pequeño estraperlo de la zona de La Fueva, acción que fue atribuida a la AGAA. En ésta, como en otras acciones relacionadas con problemas concretos, percibimos la mano de guerrilleros «autóctonos», conocedores de la conflictividad local y a menudo implicados directamente en ella.

Acciones como ésta suponían una reacción de la población, canalizada a través de los guerrilleros, frente a los problemas económicos generados por la política del régimen. Pero la guerrilla y sus simpatizantes no fueron los únicos que manifestaron una actitud de resistencia frente a dicha política; la práctica del mercado negro estaba ampliamente extendida en todos los estratos sociales, incluidos los campesinos pudientes. Según algunos testimonios orales, los propios guardias civiles «hacían la vista gorda» frente al estraperlo de harina o de aceite, e incluso se beneficiaban en ocasiones de éste, por ejemplo para adquirir aceite en cantidades mayores de las permitidas por los cupos o a precios menores de los de la tasa. ${ }^{329}$ No ocurría lo mismo con los inspectores de Abastos, figuras temidas y odiadas por la población, quienes, si se beneficiaban del mercado negro, era por canales muy alejados de ese estraperlo "casero" practicado por los pequeños productores. Y, desde luego, la actuación de la Fiscalía de Tasas distaba mucho de ser flexible: en la provincia de Huesca y durante el año 1947 se registran once detenciones por no abonar las multas de la Fiscalía de Tasas, lo que suponía el internamiento en el campo de concentración de Nanclares de

328 AHPT, sección Gobierno Civil, caja 1130, carpeta 81.

329 Entrevistas, F.A. Cantavieja, 15 de julio de 1997, y J.B. Cañada de Benatanduz, 27 de julio de 1997 . 
Oca para los hombres y en diferentes instituciones penitenciarias para las mujeres. Sólo en tres de los casos se anuló la orden de detención al efectuarse el pago de la multa. En una ocasión, la condena fue remitida porque el encausado contaba con buenos antecedentes: había sido voluntario en la Milicia de Santiago durante la guerra. Y en otro de los casos, el Gobierno Civil solicitó al fiscal de Tasas la remisión del internamiento por tratarse de un hombre que carecía de bienes y con esposa e hijos a su cargo; el gobernador civil pretendía evitar el conflicto social que esto provocaría. ${ }^{330}$

Porque la política económica del régimen provocaba el rechazo de los más variados sectores de la población, incluso de los sectores afectos al régimen: ya veíamos anteriormente las críticas del delegado provincial de Sindicatos de Teruel, Jesús Milián, respecto a la política de abastecimientos. Sin embargo, en Teruel este conflicto quedaba en cierto modo oscurecido por las dimensiones que adquirió el problema de la guerrilla, que hacía que las preocupaciones de las autoridades, principalmente de las autoridades locales, se centrasen en la lucha antiguerrillera. Los alcaldes turolenses estaban mucho más preocupados por su seguridad personal que por los perjuicios que pudiese ocasionarles la política de tasas, y sus peticiones a los gobiernos civiles y militares iban encaminados a obtener la asignación de un cuartelillo o un destacamento de la guardia civil en sus localidades, sin preocuparse de los gastos que ello pudiese ocasionar al municipio o a los vecinos, pues hay que tener en cuenta que la manutención de estas fuerzas corría a cargo de la municipalidad.

Poco tiene que ver esta actitud con la manifestada por los alcaldes oscenses, que tenían una percepción muy diferente de lo que representaba el problema de la guerrilla, así como de las prioridades en sus demandas a las autoridades provinciales. Los alcaldes oscenses parecían estar mucho más conectados con la problemática de sus convecinos que los turolenses. Más que una relación de enfrentamiento entre las autoridades locales y algunos sectores de la población, como veíamos en Teruel, lo que se percibe a través de la correspondencia municipal es una abierta hostilidad por parte de los alcaldes hacia las tropas que «invadían» sus municipios, lo cual seguramente está relacionado con la menor incidencia del problema de la

330 AHPH, sección Gobierno, caja G-1, exptes. 2111, 2023, 2040, 2041, 2046, 2057, 2072, 2073, 2075 y 2077; caja G-2, expte. 2215. 
guerrilla, mucho menos agresiva que en Teruel, y la existencia de un paisaje social más apacible, desprovisto de las profundas fracturas y conflictos que detectábamos en la sociedad rural turolense.

Las quejas más habituales que los alcaldes oscenses dirigían al Gobierno Civil tienen un matiz claramente económico y reflejan un conflicto sobre la gestión de los recursos. Se quejaban de que la concentración de tropas en la provincia amenazaba con dejar sin suministros a la población civil y, concretamente, aludían a la «superabundancia de fuerzas militares que están acaparando por todos los medios la cosecha de patata, lo que creará un enorme problema al llegar el invierno, pues este tubérculo es base principal de la alimentación en la gente no pudiente». A ello se unían protestas por la carestía de la vida, la escasez de los abastecimientos y la inoperancia del régimen frente al problema del mercado negro. Dichas quejas fueron recogidas por la Jefatura Provincial de Huesca en agosto de 1946: el problema económico primaba en estas fechas sobre los de orden público, que se presentaban en la provincia relacionados con la presencia de guerrilleros. Además, era una queja reiterada: en diciembre de ese mismo año, de nuevo «se ataca con dureza y de forma cruda y descarnada la existencia de economatos militares y de toda clase de Organismos que [los alcaldes] creen dificultan en gran manera el abastecimiento de la población civil». ${ }^{331} \mathrm{Al}$ recrudecerse las acciones de la guerrilla, las protestas cesaron: tres meses después de este informe se produjeron las muertes del alcalde de Salinas de Hoz y un transportista de Graus, la última relacionada también, como vimos, con la extensión y arraigo del mercado negro. Pero seguimos encontrando muestras de la tensión y el conflicto existentes entre las autoridades civiles y las militares. Un ejemplo: en julio de 1947, el alcalde de El Pueyo de Jaca se dirigía al gobernador civil para protestar por la actuación del comandante de las fuerzas acantonadas en este municipio. Al parecer, el ganado del ejército utilizaba pastos del municipio y los soldados pernoctaban en la cabaña con el vaquero y su mujer; el alcalde lo comunicó «educadamente» al comandante, el cual reaccionó «sin dejarme terminar de hablar con frases que me metía en la cárcel y que me iba a destituír de alcalde». ${ }^{332} \mathrm{Y}$ en septiembre se produjo

331 Jefatura Provincial de Huesca, Informes mensuales, agosto 1946 y diciembre 1946, AGA, sección Presidencia, DNP, caja 172.

332 AHPH, caja G-1, expte. 2170. 
un conflicto con varios alcaldes al negarse los ayuntamientos a satisfacer los cupos de entrega de ganado al ejército destacado en la zona, por considerarlos abusivos. Se trata de los ayuntamientos de Echo, Jaca, Biniés, Escarrilla, Tramacastilla y Lanuza. Al menos en el caso de Echo, la negativa se tramitó a través de la Hermandad Sindical Local de Ganaderos. ${ }^{333}$ Los intereses particulares y locales, en suma, primaban sobre la ideología o la lealtad al régimen. En un conflicto que enfrentaba a la comunidad con el poder central, con la presencia de los guerrilleros (en teoría, el enemigo común) como conflicto de fondo, los alcaldes se alinearon decididamente junto a sus convecinos.

En cuanto a la población oscense, afecta o no al régimen, demostraba tener una percepción marcadamente negativa de la actuación de las fuerzas represivas. Las tropas y en especial la guardia civil, la presencia más constante y cotidiana, eran percibidas como un elemento extraño, ajeno a la comunidad y perturbador de sus actividades diarias, y esto se asemeja mucho a las actitudes que percibimos en Teruel. La actitud de la guardia civil ante la población era de una prepotencia tal que incluso en algunos casos, como en Gerbe, según un informante, «[...] iba la guardia civil por la noche y le decían al alcalde que les mandara un guía, y le hacían ir delante. Y un día el alcalde le dijo que no bajaran más a por guías, que la gente del pueblo no estaba para morir allí delante de ellos. Que fueran ellos y que se las arreglaran como pudieran, pero que él no les mandaba ninguna persona que fuera por la noche delante. Porque le hacían ir por delante un trozo al otro. [...] Por si acaso, que le dieran al otro...». ${ }^{334}$ Un nuevo ejemplo de la solidaridad de una autoridad local con sus convecinos, frente al poder represivo. La percepción que tenía la población de la guardia civil era que se trataba de un poder abusivo, percepción que ha sobrevivido y se traslada al presente: en palabras de otro informante, «eso, la guardia civil entonces se aprovechaba mucho de lo que eran. Por eso

333 AHPH, caja G-1, expte. 2267. Ángela Cenarro señala que «al frente de las Hermandades fueron colocados representantes de la oligarquía terrateniente local». Cruzados..., op. cit., p. 369. El propio Mundo Obrero se hace eco de este tipo de protestas cuando indica que "los "pseudo-labradores" de las Hermandades de Labradores transmiten el malestar que reina en el campo». De lo cual deducimos que las que estamos analizando no son actitudes aisladas. Mundo Obrero, 12/12/46. Edición de Toulouse.

334 Entrevista, A.F. Guaso, 11 de agosto de 1998. 
ahora no tienen ninguna autoridad. Que cuando han tenido han tenido demasiado. Han abusado. Que aquello fue un abuso muy grande [...]».335

Los mecanismos de rechazo o de identificación funcionan desde la cosmovisión del campesino, de acuerdo con la cual cada uno debe cumplir con el papel que le corresponde: la autoridad debe proteger a la población y no abusar de su poder; el campesino debe poder realizar su trabajo sin trabas... El respeto, la solidaridad y la ayuda mutua, con un compromiso explícito de reciprocidad, son valores fundamentales en esta mentalidad campesina. Así, la identificación con los guerrilleros se producía de forma más efectiva en la medida en que los campesinos los percibían como sus iguales, y en la medida en que los guerrilleros, muchos de ellos procedentes también de un medio campesino, eran capaces de transmitir no sólo un mensaje político, sino una empatía y una comprensión reales hacia el campesinado y sus modos de vida, como aparece en este testimonio de un informante oscense que colaboró, junto con su familia, con los guerrilleros de la AGAA:

Yo sí que te puedo decir que había uno, había uno que le llamaban Manolo [se trata de Manolo Cosculluela] que también era de por ahí de La Pardina, de por ahí... ése estaba por allá abajo en unas bordas que teníamos, o sea, como unos... para guardar la hierba en fincas, pues ése estaba allí. Y nos estaba ayudando mucho a nosotros. Ese hombre, por ejemplo cuando venía la... mucho trabajo, a lo mejor se ponía un mono y nos venía a ayudar y todo. Claro, era también por mediación porque el hombre, pues venía la comida y comía también con nosotros, le dabas la comida, le dabas... sí, pero era un señor muy majo también. ${ }^{336}$

Para reclutar simpatizantes, los guerrilleros se apoyaban en una mezcla de afinidades personales y políticas. Muchos de ellos eran naturales de la zona y procedían de un medio campesino, lo que les facilitaba la comprensión de los problemas específicos del campesinado: la actitud de Manuel Cosculluela, un campesino después de todo, favorecía enormemente el acercamiento a la población, al presentarse como "uno de ellos» y participar de la tradición de ayuda mutua tan profundamente arraigada en la mentalidad campesina. En tal sentido, parece que la labor de los guerrilleros oscenses fue más efectiva que la desarrollada por la AGLA, que, como hemos visto, se centró más en la propaganda política (aunque fuese

335 Entrevista, Francisco Torres. Graus, 16 de agosto de 1998.

336 Entrevista, Francisco Coronas. El Pueyo de Araguás, 26 de agosto de 1998. 
una propaganda que reflejase la problemática campesina) que en acciones concretas en favor del campesinado.

Recapitulemos brevemente lo expuesto a lo largo de este capítulo. Para detectar los posicionamientos del campesinado respecto a la guerrilla, nos hemos basado en gran medida en las fuentes orales, pues sólo a través de ellas, ante la ausencia de documentos escritos, podemos averiguar cuál era la percepción que los diferentes sectores de población tenían del problema y la postura que adoptaban frente a él. La documentación escrita se convierte en una fuente de importancia secundaria, que nos permite enmarcar los conflictos y a sus protagonistas. ${ }^{337}$ De este modo, se observa una diferencia muy marcada entre las actitudes y los conflictos que se manifestaron en Teruel y en Huesca. En Huesca se detecta una fuerte tradición de autonomía campesina, que rechazaba toda injerencia externa, y más si la autoridad externa abusaba de su poder y lo ejercía «mal». La guerrilla aparece casi como un telón de fondo frente a conflictos de carácter más estructural, relacionados con la manera en la que se conformaban los nuevos poderes surgidos de la implantación del régimen franquista y con las relaciones de poder que se establecían entre ellos. En cambio, en Teruel los conflictos se estructuraban en torno al problema de la guerrilla, verdadero nudo gordiano de la conflictividad turolense; un nudo que la autoridad representativa del régimen, que podríamos personalizar en el general Pizarro, tuvo que cortar de un tajo ante la imposibilidad de deshacerlo. Y cortarlo de un tajo supuso aplicar una represión despiadada contra la población civil: la guerrilla estaba imbricada tan profundamente en ella que no resultaba fácil distinguir a los «buenos» de los «malos». También en Huesca se llevaron a cabo acciones represivas de gran calado contra la población, pero ya vimos que existen importantes diferencias, cualitativas y cuantitativas, entre ambas provincias, y no insistiremos más en ello.

337 Adoptamos la misma posición metodológica que muchos estudiosos del mundo campesino; por ejemplo, Raúl Soutelo y Alfredo Varela indican, en su investigación acerca de la represión en Orense: «Al abordar el estudio de la represión entre los sectores del campesinado, la pobreza cuantitativa de las fuentes directas (no casual) sobre la resolución crítica de intereses de clase que supuso la incivil conflagración desatada por la sublevación de julio, nos dicta el recurso a la fuente oral con toda su potencialidad de análisis "desde abajo" cara a una humanización del objeto a historiar». Raúl Soutelo y Alfredo Varela, "Variaciones en las formas de represión y resistencia popular en el mundo rural ourensano. 1936-1946", en José M. a Trujillano y José M. ${ }^{a}$ Gago (eds.), Historia y fuentes orales. Historia y memoria del franquismo. 1936-1978. Actas IV Jornadas. Fundación Cultural Santa Teresa, Ávila, 1997, pp. 217-233, cita en p. 217. 
En todo caso, en las dos provincias guerrilleras aragonesas percibimos la huella de una cultura y una sociedad rural autónoma, que se oponía sordamente, con los medios que tenía a su alcance, a un poder y unas normas ajenas y externas, impuestas "desde fuera» por un régimen fuertemente centralizador. En ambos casos, el rechazo más manifiesto se dirigía contra las fuerzas represivas, por razones obvias. Pero lo particular de la provincia oscense es que el rechazo se produjo en todos los estratos de la sociedad rural, incluidos los alcaldes franquistas. Se trataba de una sociedad más integrada y menos fragmentada que la turolense, y a la vez con una fuerte voluntad de independencia respecto de cualquier poder exterior; como las propias autoridades provinciales franquistas reconocían, los altoaragoneses «aspiran siempre a una vida de independencia absoluta». ${ }^{338}$ En cambio, la fuerza de la guerrilla en Teruel provocó la unión de las distintas facciones que detentaban el poder económico, político y represivo, así como la confusión entre estas tres formas de ejercicio del poder, y ello cristalizó en la colaboración absoluta de las elites locales con las fuerzas represivas externas, como se pone de manifiesto en instituciones como el Somatén o la Guardia de Franco.

En cuanto a la relación entre la guerrilla y el mundo campesino, se trataba de mundos autónomos y a la vez interrelacionados, cuyos discursos y realidades cotidianas eran muy diferentes, pero entre los que se producían frecuentes "trasvases», principalmente desde el campesinado hacia la guerrilla, en la medida en que éste le proporcionó muchos de sus efectivos y, a la vez, le transmitió las diferentes problemáticas locales y particulares, que frecuentemente se resolvieron a través de las acciones de la guerrilla. Y fueron las fuerzas represivas, en muchas ocasiones, las que establecieron el lazo entre la población y el movimiento armado, al aplicar a la población medidas destinadas, en principio, a los guerrilleros.

Por lo tanto, una parte de la población se comprometió espontáneamente con la causa guerrillera: en algunos casos por admiración hacia los guerrilleros, motivada por su mayor cultura y preparación; en otros, porque la colaboración con la guerrilla les permitió la recuperación de espacios de protagonismo que el régimen franquista les había arrebatado; y en la mayoría, pura y simplemente, por una convicción antifranquista no necesaria-

338 Cuestionario sobre haciendas locales solicitado por el gobernador civil como jefe provincial del Movimiento, AHPH, sección Gobierno. Administración Local, caja 2213. 
mente articulada en una ideología política concreta, pero no por ello sentida menos profundamente, y condicionada de modo determinante por las redes personales que establecía cada individuo con quienes le rodeaban: alcaldes, caciques, izquierdistas locales, somatenistas, guerrilleros. En dichas redes el parentesco, por ejemplo, ocupa un lugar central; si no lo tuviéramos en cuenta, no podríamos comprender muchos alineamientos y compromisos. Además, el compromiso con la guerrilla estaba basado en la identificación con una tradición izquierdista fuertemente arraigada, a pesar de todo, y construida a lo largo del tiempo como voluntad de resistencia y oposición a «la derecha» y sus personificaciones locales: los caciques, los terratenientes, el clero, las «gentes de orden».

\subsubsection{Las mujeres, "guerrilleras del llano»}

Las mujeres españolas, que habían vivido durante el período de la República un avance sin precedentes de sus derechos políticos y sociales, vieron cómo, con el establecimiento del régimen franquista, se convertían en un colectivo sometido a una subordinación específica. En efecto, los regímenes fascistas, y el franquismo entre ellos, «eran profundamente antifeministas porque menospreciaban a la mujer», en palabras de Carme Molinero, y, por otra parte, consideraban que la emancipación femenina constituía un grave peligro para la estabilidad y el orden social, puesto que "las ideologías fascistas concebían la familia como un elemento clave para su concepción organicista-nacionalista y jerarquizada de la sociedad, y la inquietud por el papel social de la mujer estaba en el corazón de la vertiente conservadora y estabilizadora del fascismo». La familia será en adelante, por lo tanto, el ámbito en el que se desenvolverá la vida de las mujeres. Su presencia en la vida pública y en el mundo laboral, que con la República había experimentado un notable avance, se verá dramáticamente recortada bajo el franquismo, excepto a través de los cauces determinados por el régimen y en el marco de las instituciones concebidas o promocionadas por éste para el encuadramiento femenino, como la Sección Femenina o la Acción Católica Femenina. ${ }^{339}$

339 Carme Molinero, «Mujer, franquismo, fascismo. La clausura forzada en un mundo pequeño", Historia Social, n. ${ }^{\circ} 30,1998$, pp. 97-117, citas en p. 101. Para la Sección Femenina en Aragón, ver el trabajo de Inmaculada Blasco, Armas femeninas para la contrarrevolución. La Sección Femenina en Aragón. IAM/Universidad de Málaga, 1999. 
Por otra parte, es preciso reconocer lo limitado de los avances que la República había aportado a las mujeres, lo que es válido sobre todo en el mundo rural: por ejemplo, la aprobación del sufragio femenino, una conquista importantísima en tanto que reconocía a las mujeres españolas su condición de ciudadanas, vio en la práctica reducida su efectividad por las altas tasas de analfabetismo femenino. Del mismo modo, las modificaciones y mejoras introducidas por la legislación republicana en materia laboral afectaron poco a las mujeres del campo, que siguieron llevando a cabo una jornada doble y, en la mayoría de los casos, sin percibir ningún jornal, a no ser que trabajasen por cuenta ajena. Esto se debía a que las familias campesinas funcionaban como unidades productivas en las que el trabajo realizado redunda en beneficio de la "casa", la verdadera unidad de producción de la economía campesina. La República en nada varió dicho sistema social fuertemente patriarcal, en el que el cabeza de familia ostentaba todo el poder de toma de decisiones y distribución de los recursos, y en el que las mujeres estaban siempre subordinadas a uno de los hombres de la familia.

Sin embargo, sí es cierto que la República trajo algunos cambios al universo mental de estas mujeres campesinas, sobre todo en su "horizonte de expectativas»: durante ese período, algunas mujeres del campo se aficionaron a la lectura e incluso consideraron la posibilidad de realizar estudios más allá de la escuela primaria. ${ }^{340}$ Tales expectativas se acentuaron en algunos casos con el estallido de la guerra civil. En la franja oriental de Aragón, la que quedó bajo el control de los republicanos, y en particular en las poblaciones en que se crearon colectividades de carácter anarquista, la influencia cultural del anarquismo se dejó sentir de forma especial en muchas mujeres. Los testimonios hablan de bibliotecas ambulantes, lecturas colectivas, creación de grupos de teatro y otras manifestaciones culturales. En concreto, la organización anarquista Mujeres Libres, uno de cuyos objetivos principales era la promoción cultural y social de las mujeres, llegó a crear federaciones en varias poblaciones aragonesas: Albalate de Cinca, Alcañiz, Alcorisa, Barbastro, Calanda, Caspe y Monzón. ${ }^{341}$ Toda esta actividad, por supuesto, terminó con la ruptura del

340 Testimonios de esta naturaleza pueden encontrarse, por ejemplo, en el audiovisual del colectivo AEVIHM, "Aguaviva, una historia en femenino» (1996).

341 Datos extraídos de Julián Casanova, Anarquismo y revolución..., op. cit. 
frente y el avance de las tropas franquistas, y con ella terminaron también las expectativas de promoción social y cultural que habían abrigado algunas mujeres.

$\mathrm{Al}$ igual que los hombres, las mujeres a las que el final de la guerra deparó la condición de «vencidas» sufrieron la represión y el ostracismo por parte de los vencedores. A ellas, además, se les reservaba un tipo de castigos específicos, como ya hemos explicado anteriormente, destinados a humillarlas en su condición femenina y con un componente de ejemplaridad. ${ }^{342}$ En el caso de los hombres, como se ha visto, esta represión determinará muchas veces, directa o indirectamente, su participación en el movimiento guerrillero. Pero en el caso de las mujeres aragonesas, las cosas van a funcionar de forma un tanto diferente. En Aragón las mujeres están casi completamente ausentes del movimiento guerrillero y esta ausencia mueve a la interrogación, tanto más cuanto que no es generalizable al resto de España, y así encontramos casos relativamente abundantes de mujeres guerrilleras en León y Galicia, principalmente, pero también en Andalucía y Extremadura. Según señala Secundino Serrano, la presencia de mujeres en el monte fue más numerosa durante la época de los "huidos», antes de que la guerrilla se organizase militarmente, y «una vez se organizó el maquis, su número descendió drásticamente». ${ }^{343}$

Creemos que la ausencia femenina de las filas de la AGLA y de la AGAA se debe, en gran parte, al hecho de que en Aragón la guerrilla adoptó desde un principio, de la mano del PCE, una estructura fuertemente organizada, jerarquizada y militarizada, en la que el papel de las mujeres estaba definido de antemano como auxiliar, de apoyo: de retaguardia, en suma. En este caso, el PCE no hacía sino seguir su propia consigna del otoño de 1936, cuando se retiró a las milicianas del frente: «Los hombres al frente, las mujeres a la retaguardia». También la guerrilla tenía un frente, el monte, y una retaguardia, las masadas y los pueblos, el «llano» en el cual actuaba la red de colaboradores de los guerrilleros, muchos los cuales eran mujeres: se

342 Un estudio específico sobre la represión femenina en una provincia aragonesa, en este caso Teruel, en Javier Barrado, «Mujer y derrota. La represión de las mujeres en el Teruel de posguerra (1939)", en Tiempos de silencio. Actas del IV encuentro de Investigadores del Franquismo. Valencia, 17-19 de noviembre de 1999, pp. 7-11.

343 Secundino Serrano, Maquis. Historia de la guerrilla antifranquista. Temas de Hoy, Madrid, 2001, p. 223. 
trataba de las «guerrillas del llano», también denominadas «enlaces» y «puntos de apoyo». La propia Dolores Ibárruri reivindicaba específicamente este papel para las mujeres cuando, con motivo de la celebración del 8 de marzo de 1946, les dirigía consignas como «Ayudad a los heroicos guerrilleros!». El papel que destinaba a las mujeres en relación con la lucha guerrillera es bastante tradicional, aunque también aludía a la lucha directa en acciones sindicales, huelgas, etc. Mencionaba, asimismo, la acción colectiva femenina y la solidaridad internacional entre las mujeres a través de la Federación Sindical Mundial, pero jamás reivindicó la lucha armada protagonizada por mujeres. ${ }^{344}$ También Irene Falcón, cuando aludía a la relación de las mujeres con la lucha guerrillera en un artículo titulado «Heroínas de nuestro pueblo», se refería a acciones tales como las tradicionales funciones de apoyo a los guerrilleros, huelgas, etc. Ese carácter de apoyo parece que tuvo la denominada Agrupación Femenina Pasionaria, de Ciudad Real, calificada de «reserva guerrillera». 345

Para explicar las diferencias en cuanto a las funciones reservadas a las mujeres en las diferentes guerrillas españolas, podemos suponer que, cuando la guerrilla tenía su origen en un proceso generado "desde abajo» y tanto su composición como su estructura presentaban un carácter plural, como era el caso de la Federación de Guerrillas de León-Galicia, las mujeres encontraron más facilmente un sitio entre los guerrilleros, aunque siguieron siendo más numerosas las que se dedicaban a funciones de apoyo y suministro. ${ }^{346}$ Estas funciones, aunque tradicionalmente consideradas «secundarias», eran vitales para la supervivencia del movimiento guerrille-

\section{Mundo Obrero, 9/3/46. Edición de Toulouse.}

345 Mundo Obrero, 1/5/46. Edición de Toulouse.

346 Los trabajos acerca de las funciones desempeñadas por las mujeres en las diferentes guerrillas españolas son escasos y se reducen a algunos artículos, que insisten regularmente en estas funciones de apoyo material y moral a los hombres guerrilleros, con los que generalmente están emparentadas. Ver, por ejemplo, Inmaculada Cordero y Encarnación Lemús, «La malla de cristal: actividad política y vida de las comunistas andaluzas en la clandestinidad de los años cuarenta», Spagna Contemporanea, n. ${ }^{\circ} 15,1999$, pp. 101-120, que, aunque no trata específicamente el tema de la guerrilla. sí se refiere a él de pasada; y sobre todo Julio Prada Rodríguez, «Las mujeres de los escapados: aproximación al papel de las mujeres como soporte material de la resistencia antifranquista", en Las mujeres y la guerra civil española. III Jornadas de Estudios Monográficos. Salamanca, octubre de 1989. Ministerio de Cultura, Madrid, 1991, pp. 218-223. En los libros de Fernanda Romeu, El silencio roto: Mujeres contra el franquismo. Ed. de la autora, 1994, y de Giuliana Di Febo, Resistencia y movimiento de mujeres en España. Icaria, Barcelona, 1979, también se alude a la relación de las mujeres con la lucha armada antifranquista, sobre todo en las cuestiones relacionadas con la represión. 
ro, y además no estaban en absoluto exentas de riesgos. De hecho, los enlaces que habían huido al monte por haber caído bajo las sospechas de la guardia civil eran una de las fuentes más importantes de reclutamiento de la guerrilla. Pero la opción de la huida al monte sólo era contemplada en el caso de los hombres: las mujeres se quedaban, lo cual podía revestir consecuencias trágicas. ${ }^{347}$

Es posible también, sin embargo, que las propias mujeres se encontrasen más cómodas ejerciendo estas tareas que encajaban con las funciones que desempeñaban tradicionalmente, relacionadas con la alimentación y el cuidado de la familia, y que para ellas la huida al monte representase una opción extrema y poco atractiva. El desempeño de las funciones que podemos calificar de "maternales» estaba sin duda reforzado por el hecho de que estas mujeres eran en muchos casos familiares directas de los guerrilleros: esposas, madres, hermanas o hijas. Por otro lado, ésa, precisamente, era la imagen de la feminidad que se quería transmitir desde la dirección comunista, en la que se producía una fuerte identificación entre las figuras de «mujer» y «madre». Para los comunistas españoles, la imaginería de la mujer-madre está representada en la propia Dolores Ibárruri, que es una figura «maternal» (en su iconografía y en la imagen que proyectaba de sí misma, la de una mujer campesina tradicional, vestida de oscuro y con el pelo recogido en un moño). Se trata de una maternidad que no significa necesariamente pasividad, sino que se caracteriza por la abnegación de quien entrega a sus hijos a la patria, supremo sacrificio que se pide a las mujeres españolas, tanto en el discurso bélico de la guerra civil como en el de la guerrilla, ambos muy semejantes entre sí. ${ }^{348}$

347 Para la AGLA, sólo conocemos un caso de mujeres enlace que se echaron al monte con otros familiares para escapar de la represión, el de las hermanas Martínez y Remedios Montero en la provincia de Cuenca, que ya fue descrito en Mercedes Yusta, La guerra de los vencidos..., op. cit, pp. 106-116. En cuanto a las consecuencias trágicas de la represión, un caso extremo es el de Felisa Montoliu, esposa de Florencio Guillén, el Viejo, que se analiza en un capítulo anterior.

348 Ver Yannick Ripa, «Le mythe de Dolores Ibárruri», en Catherine Marrand-Fouquet (coord.), Clio. Histoire, femmes, sociétés. N. o 5: Guerres Civiles (1997), pp. 147155; y Rafael Cruz, Pasionaria. Dolores Ibárruri, historia y simbolo. Biblioteca Nueva, Madrid, 1999. 
Sin embargo, no debemos olvidar que la actividad de las mujeres está a menudo nublada por la invisibilidad a la que han sido sometidas por la historiografía tradicional, por los dirigentes de las organizaciones políticas y, en algunos casos, por sus propios compañeros. La dificultad de oír las voces de las mujeres, además, se acrecienta en el estudio de un movimiento clandestino, que no llevaba registros de actividad ni elaboraba listas de colaboradores/as. Con muchas dificultades, hemos logrado descubrir algunos nombres de mujeres que desempeñaron un papel importante en las actividades de la guerrilla aragonesa. Son nombres que raramente aparecen en documentos escritos (con la excepción de Josefina Buil, lo que da idea de la excepcionalidad e importancia de las tareas que desempeñó), y las propias mujeres son reacias a destacar la importancia de los hechos en los que tomaron parte, minimizando sus acciones por modestia o tal vez por un miedo que no ha desaparecido con el paso de los años.

El grueso de estas mujeres actuaban en colaboración con la guerrilla debido a sus lazos de parentesco con algunos de los guerrilleros: se trataba de sus madres, hermanas o compañeras. En este caso se encontraban Carmen Ciprés, esposa del guerrillero Petrol, o Aurora Piñana, la mujer de José Mir, Cona, de las que se hablaba en un trabajo anterior, ${ }^{349}$ así como Asunción Cubero, la madre de Manuel Pérez Cubero, el Rubio. Este último destaca el importante papel desarrollado por las mujeres, auténticas "guerrilleras del llano» que ejercían una labor sumamente expuesta, desprovistas de armas y víctimas probables de la represión desatada contra los apoyos civiles de la guerrilla:

Ya en el año 1946 los Consejos de Resistencia son fuertes, la mujer juega un papel fundamental, incorporada a la lucha a través de los Consejos de Resistencia, desarrollan labores de correo entre ciudades y pueblos; forman parte del aparato de información Fiable. Entre otras cosas trabajan tejiendo lana, haciendo guantes, jerséis, bufandas para los presos y guerrilleros.

El Consejo de Resistencia de la Estación de Rubielos con enlace con Albentosa y los Mases, al que pertenecía Asunción Cubero Royo (detenida a finales del año 1947) mantenía el enlace del Partido comunista con Valencia y las guerrillas.

Como otras, trabajan sin descanso tejiendo para presos y guerrillas. $\mathrm{Al}$ subrayar más arriba fiable es por la sencilla razón de que la madre ser racional o irracional defiende a sus hijos de una manera fiel y no se arredra ante el peligro, ni el enemigo para defender lo que más quiere en su vida.

349 En Mercedes Yusta, La guerra de los vencidos..., op. cit., pp. 106-116. 
La vida que he llevado y compartido en la lucha junto a mis semejantes, me ha hecho comprender como hombre, que lo más fiel a una causa, entre el ser humano, es la mujer convencida de sus ideas [...] En la clandestinidad afrontando todos cuantos peligros acechaban en la vida; la cárcel de ella y su familia. En las que gracias a ese tesón que las caracteriza han sido el sustento de las guerrillas; muchas páginas de leyenda e historia se podrían escribir de estas familias que de una manera honesta y sencilla se enfrentaban a todos los riesgos que supone la lucha, en aras de la libertad; muchas dieron su vida por esta causa, han perdido sus hijos o maridos. ${ }^{350}$

En este testimonio, Manuel Pérez Cubero pone de relieve que las mujeres luchan movidas, por una parte, por una conciencia de su labor como sostenedoras de la familia y garantes de su supervivencia, que las lleva en ocasiones a enfrentarse al orden establecido y que Temma Kaplan ha denominado "conciencia femenina», ${ }^{351}$ pero, por otra, por la fidelidad a unas ideas o a una causa que no tiene por qué expresarse en la racionalización de un ideario político concreto, aunque también aparece esa idealización de la maternidad que, como hemos visto, es corriente en el discurso comunista. Esta forma de actuar que mezcla motivaciones personales y políticas (en un sentido amplio de «antifranquismo») no es privativa de las mujeres, sino también de muchos campesinos que encontraron en la ayuda a las guerrillas una manera de canalizar su repulsa al régimen y de actuar contra la aplastante represión que acompañó a su institucionaliza-

350 Manuscrito sin firmar. Sin fecha. Archivo de la autora.

En un documento del Gobierno Civil de Teruel, se da cuenta de la detención de Asunción Cubero Royo, «sospechosa del atentado cometido en la vía férrea del CentralAragón (entre Barracas y Rubielos de Mora)». El informe se completa con la información de que «vive muy cerca de la estación de Rubielos de Mora [y por tanto] es sospechosa de haber colocado el artefacto. Tiene a su hijo y hermano con los bandoleros. Se sospecha actúa de enlace de los Guerrilleros de Levante. Asunción se informó sobre las personas que delataron a los miembros de un partido extremista de Albentosa (información sin duda solicitada por los bandoleros)». AHPT, sección Gobierno Civil, caja 1085, carpeta 40.

351 Temma Kaplan, "Conciencia femenina y acción colectiva: el caso de Barcelona, 1910-1918», en James S. Amelang y Mary Nash (eds.), Historia y género. Las mujeres en la Europa moderna y contemporánea. Alfons el Magnànim, Valencia, 1990, pp. 267-295. Este concepto de conciencia femenina ayuda a comprender determinadas movilizaciones femeninas que no tienen como objetivo una reivindicación específicamente feminista. En tales casos, las mujeres se movilizan o desarrollan estrategias relacionadas con su papel tradicional de garantes de la supervivencia de la familia, como madres o esposas, uniéndose en estas reivindicaciones a otras mujeres con las que se identifican no en tanto que mujeres, sino debido a esa condición común de madres o esposas, reclamando del Estado el derecho a desempeñar estas funciones que les han sido atribuidas por la propia sociedad patriarcal. 
ción.

También Doroteo Ibáñez, enlace de la AGLA con Francia, destaca en uno de sus informes la importancia de las redes de mujeres organizadas para el apoyo material de la guerrilla:

El sector del camarada Ibáñez, es decir el $11 .^{\circ}$, organizó a mujeres del P. para trabajar en ayuda a los guerrilleros. Ellas les hacían jerseys de lana y también calcetines. Unas veces eran ellos quien compraban la lana y otras las propias camaradas. Alguna también solía subir a algún campamento, sobre todo una del pueblo de Higueruelas (Cuenca) a la cual la propia guardia civil la llama «la Pasionaria» por su rebeldía. Ella está muy orgullosa de que la llamen así. Es buena y valiente. En total este sector tenía de esta forma organizadas a 20 o 25 mujeres [...]. De esta forma, agrega Ibáñez, no había un guerrillero de nuestro sector que fuese en invierno sin jersey. Esto no sucedía en los demás sectores. ${ }^{352}$

Cuatro de las mujeres que probablemente participaban en esa red de mujeres de la que habla Ibáñez, las tres hermanas Martínez y Remedios Montero, residentes en una aldea de Cuenca, debieron más tarde incorporarse a la guerrilla ante la posibilidad de ser detenidas, y fueron las únicas mujeres que figuran oficialmente como guerrilleras en los anales de la AGLA. No incluimos a Teresa Pla Meseguer, que actuó en la zona del Maestrazgo, por su probable condición de hermafrodita, ${ }^{353}$ condición sexualmente ambigua que era reconocida por los propios guerrilleros comunistas en sus informes, en los que aparece con el apodo de Durruti: «Se incorporó al 23. ${ }^{\circ}$ con Carlos. Andaba de pastor vestido de mujer. Todo el mundo lo tomaba por una mujer. Servía de enlace. Parece ser que es hermafrodita. Se incorporó porque la guardia civil descubrió un grupo en su casa, mientras se encontraba con el ganado». ${ }^{354}$ Versión, por cierto, muy diferente a la popular que circula por el Maestrazgo, que achaca su incor-

352 Informe del camarada Ibáñez sobre la AGL, Archivo del Comité Central del PCE, sección Movimiento Guerrillero, jacquet 3-9.

353 En 1978 apareció en la revista Interviú un reportaje acerca de Teresa Pla, en el cual se verificaba esta condición de hermafrodita por el hecho de que, en el momento de realizarse el reportaje, Teresa había adoptado una identidad y una apariencia completamente masculinas y se hacia llamar Florencio. "La pastora, tragedia de un hombre nacido mujer. El maquis hermafrodita acusado de 28 crímenes», Interviú, n. ${ }^{9} 98,30$ de marzo al 15 de abril de 1978, pp. 28-30.

354 Informes AGLA, mayo del 49, Archivo del Comité Central del PCE, sección Movimiento Guerrillero, Equipo de pasos, informes sobre camaradas, sign. 635-636. 
poración a una agresión sexual sufrida por Teresa a manos de los guardias. Teresa Pla ha de ser considerada como un caso excepcional, tanto por su extraordinaria historia personal como por las innumerables leyendas a las que dio lugar y que son todavía fácilmente rastreables en la memoria oral de todo el Maestrazgo.

Otras mujeres, como Josefina Buil, de la que ya hemos hablado largamente, representaron un apoyo importantísimo para la guerrilla como enlaces entre ésta y las ciudades, por ejemplo. La propia Josefina Buil relata cómo se estableció en Monzón una red de colaboración entre mujeres, muchas de las cuales eran anarquistas, para proporcionar apoyo material tanto a los guerrilleros como a los presos, funciones que en muchas ocasiones estaban estrechamente unidas. Sin embargo, es sumamente difícil localizar a estas mujeres, tanto por su ausencia de la documentación escrita (que, en el mejor de los casos, da cuenta de su detención sin especificar muchas veces los motivos) como por su propio silencio. Por eso, sospechamos que las mujeres que tuvieron una colaboración directa con la guerrilla son bastante más numerosas que las que hemos podido localizar o documentar de alguna forma.

Además de la participación activa en el apoyo a la guerrilla, muchas mujeres de este mundo rural aragonés de los años cuarenta, sacudido por la violencia, se rebelaron a su manera contra la situación en la que vivían. Encontramos tal actitud de rebeldía en los testimonios de varias mujeres, que eran jóvenes en la época en la que se desarrollan los hechos y que reaccionaron contra un poder impuesto por el temor con la única arma que poseían: la palabra. Así lo hizo, por ejemplo, Piedad Marqués, de Libros, que insultó a los guardias que se llevaban detenidos a sus padres como enlaces de la guerrilla, llamándolos «canallas» y «bandidos», y que por este hecho fue detenida y entregada a las autoridades militares, con lo que su reacción de rebeldía espontánea fue equiparada a un acto de subversión contra el Estado, representado en la figura de los guardias. Y así lo hicieron otras mujeres que denunciaron a las autoridades las arbitrariedades a las que eran sometidas, ellas o sus familias, como una mujer de Castellote (Teruel) que se enfrentó a una pareja de la guardia civil al ver que habían dado una bofetada a su padre, o como otra de Pallaruelo (Huesca), que, pese a ser "de derechas», hará frente también a la guardia civil ante la detención de su marido, acusado de dar de comer a un grupo de guerri- 
lleros (que, por otra parte, se habían presentado en su casa y les habían amenazado si les denunciaban a la guardia civil). Esta mujer denunció la situación de indefensión en la que se encontraba la población, atrapada entre guerrilla y guardia civil, y acusó a esta última de no protegerlos, como era su obligación según su razonamiento de mujer campesina: «Ustedes están recogiendo a los buenos, y los malos no. Pa qué los dejaron venir aquí [...] Vienen ahora. ¿Por qué no vinieron para que no vinieran taquí los maquis? Desde esta cría que tengo aquí en la falda hasta aquí el abuelo, dijeron que si dábamos parte que nos matarían. Una casa sola. ¿Por qué no nos vinieron a guardar?». 355

Queremos destacar la importancia de dichos actos, que pueden parecer banales pero que suponen por parte de estas mujeres una actitud no sumisa, de defensa de la dignidad propia y de los suyos. En el medio rural, muchas mujeres asumieron la función de denunciar las injusticias y defender la dignidad y el derecho a vivir conforme a las normas internas de la comunidad (unas normas que suponían solidaridad con quien iba a pedir asilo, como eran los guerrilleros, derecho a la seguridad, como denunciaba la mujer de Pallaruelo, y derecho a realizar las labores cotidianas sin las trabas impuestas por un régimen represivo). Las mujeres, más indefensas, manifiestan su rebeldía por medios que les son propios: no por el de coger un arma (que, por otra parte, es una actitud que les está vedada por normas no escritas), no por el recurso a la violencia, sino por la denuncia pública y espontánea de lo que es injusto e inadmisible. Estas actitudes se englobarían dentro de lo que Scott denominaba "pequeñas rebeldías cotidianas", y constituyen una reacción típica de la población rural, en ocasiones la única posible, frente a la represión arbitraria (y también cotidiana) de la que eran objeto.

En cuanto a la organización política responsable de la guerrilla en Aragón, el PCE, parece que fue haciéndose consciente progresivamente de la existencia de una problemática específicamente femenina, como comprobamos cuando, en el último número de Mundo Obrero aparecido en París antes de la ilegalización del PCE en Francia en septiembre de 1950, leemos un artículo acerca de «la brutal explotación de la que se hace vícti-

355 AHPT, sección Gobierno Civil, caja 1085, carpeta 53. Entrevistas, R.A. Graus, 21 de agosto de 1998, y F.R. Aguaviva, 13 de abril de 1997. 
mas a las mujeres», en el que se resalta la enorme diferencia de salarios entre hombres y mujeres en la España franquista. Pero esto no significa que las organizaciones de la oposición, y concretamente el PCE, hiciesen un examen de conciencia acerca de su propia postura con respecto a las mujeres, aunque de forma individual sí se llevasen a cabo tales análisis por parte de algunos individuos. ${ }^{356}$

Por el momento, eran las propias mujeres las que aceptaban de lleno la política de oposición de los partidos de izquierdas, sin plantearse la reivindicación de sus intereses específicos de género. Eran conscientes de que, en esa coyuntura, la lucha prioritaria era la lucha contra el régimen franquista, y que, durante la década de los años cuarenta, y posteriormente, su apoyo y su militancia oscura y abnegada eran necesarias para el éxito de las acciones, más visibles, llevadas a cabo por los hombres. La conciencia de clase precedía, por tanto, a la conciencia de género en las mujeres que se implicaron en cuerpo y alma en la oposición antifranquista, materializada en nuestro caso en la lucha armada de los guerrilleros. Pero estas mujeres «conscientes» fueron excepciones. La inmensa mayoría de las mujeres campesinas, como la mayoría de los hombres, sufrieron el proceso de despolitización total y amnesia colectiva que acompañó al régimen franquista durante toda su existencia.

356 Mundo Obrero, 7/9/50. Edición de París. Mujeres Antifascistas, el boletín de la UME, sí aparecían regularmente artículos referentes a problemáticas específicamente femeninas, aunque en general el tono de la publicación estaba subordinado a los intereses políticos inmediatos del PCE. 


\section{CONCLUSIONES}

En un éclair, tout était vide comme si rien n'était arrivé. Rien. Ni personne. Jamais.

Il ne restait aucune trace. Plus une trace!

Comme par magie, tout était disparu.

(Claude Lanzmann, Shoah)

Cuarenta años de franquismo han dejado una huella muy profunda en nuestra memoria colectiva. $\mathrm{O}$, más que una huella, un hueco. Las disidencias, las rebeldías, las resistencias contra la imposición del régimen franquista forman parte de ese hueco; todas las actitudes, individuales y colectivas, que suponían la oposición o el desacuerdo frente al estado de cosas imperante, y que fueron ocultadas mediante la represión, física o de otro tipo, la censura de prensa, la educación nacionalcatólica, el lavado de cerebro colectivo. Por eso, algunos hechos que sucedieron durante estos años silenciados todavía van saliendo poco a poco a la luz. La resistencia armada contra el franquismo ha sido uno de los últimos fenómenos en suscitar el interés de una historiografía comprometida con la tarea de rescatar la historia de la oposición antifranquista de las manos de hagiógrafos o satanizadores. Y sin embargo, la resistencia armada, la guerrilla, reviste un gran interés historiográfico como encrucijada de los diversos estratos sociales que convivían en el mundo rural español. Fue un fenómeno plural, heterogéneo y complejo, y, sobre todo, de una gran importancia, no sólo en sí mismo, sino por todas las consecuencias que acarreó y que apenas ahora comenzamos a vislumbrar. A pesar de ello, una vez que cesó la amenaza guerrillera, su traza desapareció sin dejar rastro. Quedó sólo en la memoria de quienes vivieron con el miedo a las espaldas durante casi diez años, de quienes hoy todavía bajan la voz para hablar de «los maquis». 
La existencia y pervivencia de un movimiento armado en España después del final de la guerra civil ha de explicarse aludiendo a factores tanto internos como externos. La guerra civil, de hecho, fue el primer campo de batalla europeo en el cual se enfrentaron el fascismo y el antifascismo, en el sentido más amplio del término. Y la situación internacional representó un importante papel en los acontecimientos que se desarrollaron en España a partir de 1939. Pero además, la existencia de la guerrilla respondía a una situación interna, al hecho ineludible de que muchos de los opositores del interior vieron en la lucha armada una posibilidad de supervivencia, la única, en un régimen que se basaba en su exclusión y eliminación. La táctica del PCE de apoyo a la lucha armada respondía, por lo tanto, a una realidad: los grupos armados existían, los militantes del interior se organizaban y el Partido Comunista se vio en la obligación de sostenerlos, de proporcionarles una salida viable, a la vez que en esta lucha había para el PCE una posibilidad de afirmar su propio poder y supremacía entre las fuerzas de la oposición. La lucha armada era, pues, a la vez una necesidad, demandada por la realidad insoslayable de la militancia que solicitaba apoyo exterior para la reconstrucción de la oposición interior, y una fuente de legitimación. Pero además, como ha quedado de manifiesto a lo largo de la investigación, la conflictividad relacionada con la guerrilla enlazaba con conflictos anteriores, propios de la sociedad campesina en la que se implantó. Conflictos relacionados con el uso y la propiedad de la tierra, viejas rencillas entre vecinos que encontraron en esta situación de violencia generalizada un marco en el que manifestarse de forma abierta, produciendo la alineación de los campesinos a favor o en contra de los guerrilleros, o incluso la incorporación a la guerrilla de algunos de éstos como única salida para resolver sus propios conflictos personales. Unos conflictos que tenían que ver, más que con alineamientos políticos concretos dentro de las izquierdas, con una problemática de carácter social y con la cuestión agraria, que ni las tibias reformas de la Segunda República ni mucho menos la política económica del régimen franquista (basada en un sistema de autarquía, expropiación y coacción del pequeño campesinado) habían resuelto.

El caso de Aragón es modélico para seguir este proceso. El desarrollo de la guerra hizo que los combatientes republicanos fueran empujados hacia la zona levantina y Cataluña, y de allí hacia el exilio, dejando la región en manos de las tropas franquistas, que desataron un impresionante des- 
pliegue represivo apoyadas por los sectores de la población que les eran favorables y que habían sido perjudicados por la actuación de las fuerzas gubernamentales, sobre todo en la franja oriental de la región, en la cual se había desarrollado la experiencia revolucionaria de las colectividades. La oposición política quedó truncada y sólo recibiría un nuevo impulso cuando la liberación de Francia condujese a los republicanos españoles que habían luchado en ella, organizados por los comunistas, a penetrar en el interior. Lo que se conoce como «invasión del valle de Arán» fue una aventura frustrada, pero, en todo caso, constituyó también un trampolín de partida. El PCE no renunciaba a la lucha en el interior ante la evidencia de que esa lucha ya existía, y aprovechaba además el malestar producido entre el campesinado por una política económica ineficaz y con tintes incautatorios.

La táctica adoptada por el PCE en estos momentos sólo se reprodujo en el mismo momento en otro lugar de Europa: Grecia. En los restantes países en los que existió durante la segunda guerra mundial una resistencia interior con fuerte participación de los comunistas, como Italia, Francia o Yugoslavia, la lucha cesó en el mismo momento en que lo hizo la ocupación alemana. En los dos primeros países, la caída del fascismo abrió la posibilidad del diálogo democrático, y los conflictos se resolvieron en la arena política, aunque esta resolución supusiera, a la postre, el fracaso del proyecto insurreccional que se había gestado en el seno de los movimientos de resistencia. En Grecia, la fuerza del movimiento armado creado por los comunistas y los intereses internacionales aguzados por el comienzo de la guerra fría y la política de bloques, así como las condiciones geográficas y sociales de la península helénica, convirtieron la lucha en una guerra civil. Pero España ya había tenido su guerra civil. La prudencia de los Aliados y la brutalidad de la represión hacían prácticamente imposible que el conflicto se convirtiese en un enfrentamiento abierto. La posición excéntrica de España, además, no la convertía en un campo de batalla primordial. Y la guerrilla nunca llegó a ser lo suficientemente fuerte para amenazar la existencia del régimen, aunque hiciera peligrar su estabilidad.

No podemos dejar de admitir que la existencia de la guerrilla condujo, en último término, a un fuerte incremento de la represión. El régimen reforzó su estructura policial, en detrimento de otros medios para conseguir estabilidad y consenso. Las medidas represivas adoptadas durante los años cuarenta dan fe de ello, y probablemente también la dará el estudio de la evolución de la población reclusa. La lucha antiguerrillera se convir- 
tió en una guerra sin cuartel, una guerra en la que todo estaba permitido con tal de acabar con el foco de disensión y de disuadir a la población de participar en este nuevo conflicto. Y no se trataba sólo de disuadir, sino también de movilizar a aquellos que eran susceptibles de ser movilizados, como lo demuestra la existencia de los somatenes. El régimen elaboró un completo discurso para tratar de que la población se identificase con él y considerara que «los maquis» eran simplemente un grupo de personas «fuera de la ley» que perjudicaban el interés general.

Pero el interés general no era general para todos. ¿Cómo pretender que un pequeño campesinado aterrado y empobrecido, sometido a la guardia civil y los inspectores de la Fiscalía de Tasas, se identificara con el régimen? Consideramos que este discurso fue, a grandes rasgos, un fracaso, excepto para ciertos sectores que realmente se vieron perjudicados por la actuación de la guerrilla. Lo que funcionó en aquel momento fue el miedo. Y de ello fueron probablemente conscientes los dirigentes comunistas, al decidir cambiar la lucha armada por una lucha de carácter político y sindical, que entre otras cosas ofrecía las ventajas de ser menos arriesgada y enfrentarse a una respuesta menos violenta por parte de las fuerzas represivas, además de ser probablemente más efectiva en dicha coyuntura. En el origen de este "cambio de táctica», según todos los indicios, se encuentran indicaciones expresas de Stalin. Pero no hay que dejar de lado la consideración de que la lucha guerrillera estaba entonces abocada al fracaso. Por tanto, la pregunta que habría que formular es por qué, si en 1948 la decisión ya estaba tomada, el PCE siguió enviando armas y hombres al interior, por qué las acciones armadas no cesaron hasta entrada la década de los cincuenta.

¿Cuál era el objetivo de la guerrilla: vencer o desestabilizar? ¿Había realmente esperanzas de provocar una insurrección generalizada contra el régimen? Nada nos permite pensar así. Y nos encontramos, además, con el hecho de que, al escribir la historia de la guerrilla, devienen tan importantes las decisiones individuales como la estrategia global determinada por el PCE. Decisiones individuales que, en muchas ocasiones, no respondían a una motivación política, sino que a menudo estaban relacionadas con el hecho de que la guerrilla no era un bloque homogéneo, perfectamente organizado y que siguiese una línea política clara y definida. En todo caso, sólo era así en las mentes de los dirigentes comunistas que manejaban los hilos de la política guerrillera desde el exilio. En el interior de las agrupaciones guerrilleras aragonesas, sobre todo de la AGLA, la rea- 
lidad era mucho más compleja: en ella convivían guerrilleros procedentes de Francia y de la lucha contra los nazis en el seno de la Resistencia, y otros que se incorporaron desde el interior. Había guerrilleros comunistas, fuertemente politizados, y anarquistas. $\mathrm{Y}$ el componente anarquista correspondía frecuentemente con los guerrilleros procedentes del interior, así como el comunista con los llegados «de fuera». La interacción entre ambos grupos fue problemática: más conectados con la realidad local, los guerrilleros «autóctonos» tenían una visión de la lucha guerrillera que contrastaba, frecuentemente, con las directrices emanadas del PCE y aplicadas por los guerrilleros comunistas que tenían el mando de la guerrilla.

El individuo se reinserta por esta vía en la historia. Cuando en 1947 el guerrillero Florencio Guillén, en Gúdar, fusiló a nueve rehenes como venganza por el asesinato de su mujer, su decisión prevaleció sobre las órdenes emanadas de la dirección de la guerrilla o del PCE. La respuesta a la pregunta que planteábamos más arriba comienza, pues, por señalar que cuando se pone en marcha un mecanismo de este tipo, una conflictividad decididamente violenta pero que a la vez no es una guerra abierta, declarada, no es tan fácil detenerlo. La guerrilla no era sólo una lucha política en el sentido estricto del término, es decir, una lucha entre facciones políticas que se disputan el poder. Tampoco era una guerra de liberación nacional, puesto que no había un ocupante extranjero (y esto es determinante para comprender la diferencia entre el «maquis» español y otras guerrillas antifascistas europeas). La guerrilla en España fue fruto también de una conflictividad profunda que se desarrolló en el seno de las comunidades rurales, fruto de la ruptura de las leyes de la convivencia social provocada por la guerra civil. Esto es cierto, sobre todo, en Teruel, donde los conflictos habían revestido un carácter más violento que en Huesca, lo cual se reflejó posteriormente en la diferente evolución de las zonas guerrilleras del norte y el sur de Aragón. La guerrilla reprodujo, de manera muy fiel, las líneas de fractura que se habían abierto durante la guerra civil: parafraseando a Clausewitz, la guerrilla fue la continuación de la guerra por otros medios.

La guerra civil, con el desmantelamiento del poder legítimamente constituido, trajo consigo la posibilidad de solventar los conflictos existentes de forma violenta. Porque, además, la coyuntura no permitía tampoco resolverlos de otra forma. Y ello supuso una fractura profunda en el seno de las comunidades rurales, una fractura sobre la que se instaló la apa- 
rición de la guerrilla, ahondándola. Estamos en un nivel de análisis local; en este nivel, la guerrilla es el instrumento mediante el cual se resuelven los conflictos individuales, como antes lo había sido la guerra civil. Cuando este fenómeno se produce de forma generalizada, como sucedió en Aragón y en toda España en los años cuarenta, ello significa que el poder existente no ofrece otras vías de resolución de conflictos. Que se trata, como ya sabemos, de un poder represivo al servicio de una fracción de la población. Y que la lucha de los guerrilleros es la lucha de los excluidos, y la clandestinidad un espacio de supervivencia, puesto que en dicho régimen no hay espacio para la disidencia y tampoco para la amnistía.

La sociedad española seguía siendo, después de 1939, una sociedad en guerra, profundamente fracturada y en la que el conflicto civil no se había resuelto, en modo alguno. Durante los años cuarenta, España entera, y con ella las zonas de Aragón que hemos estudiado como escenario de actividades guerrilleras, se convirtió en lo que había sido durante los años de la guerra la retaguardia de la zona «nacional». Un territorio férreamente controlado por una autoridad militar, policial y también económica, con los recursos existentes puestos al servicio de las elites, en estado permanente de alarma, con las fuerzas represivas constantemente movilizadas y la población disidente implacablemente reprimida. Territorio de «topos», huidos y guerrilleros. Retaguardia sin frente, puesto que el frente estaba un poco en todas partes. 


\section{FUENTES Y BIBLIOGRAFÍA}

\section{A) Archivos y centros de documentación}

Archivo Histórico Nacional

Archivo General de la Administración del Estado (Alcalá de Henares)

Archivo del Comité Central del PCE

Archivo de la Fundación Pablo Iglesias

Archivo del Gobierno Civil de Castellón

Archivo del Gobierno Civil de Zaragoza

Archivo Histórico Provincial de Huesca

Archivo Histórico Provincial de Teruel

Archives Nationales de France

Archives Départamentales de la Loire

Archivo personal de Irène Tenèze

Archivo personal de Vicente López Tovar (documentación cedida por Jesús de Cos Borbolla)

Archivo Municipal de Aínsa

Archivo Municipal de Boltaña

Archivo Municipal de Cantavieja

Archivo Municipal de Graus

Archivo Municipal de Mas de las Matas

Archivo Municipal de Morella

Biblioteca Nacional Española

Bibliothèque de Documentation Internationale Contemporaine. Université de Paris X-Nanterre

Bibliothèque Nationale de France

Centro de Estudios Históricos de la Guardia Civil. Dirección General de la Guardia Civil

Hemeroteca de Zaragoza 


\section{B) Fuentes hemerográficas}

Anónimos. Portavoz de la 26 División de la Agrupación de Guerrilleros Reconquista de España. Chalabre (Aude)

CNT. Órgano del Movimiento Libertario. Época VI. España

Combat. De la Résistance à la Libération

Cultura y Acción. Órgano de la Confederación Regional del Trabajo de Aragón, Navarra y Rioja

Défense de la France. Le grand quotidien du soir. Fondé sous l'occupatione ennemie le 14 juillet de 1941

Le Figaro

Fragua social. Órgano del Comité Regional de Levante y Portavoz de la CNT. Información, Orientación y Combate del Movimiento Libertario

Franc-Tireur. À l'avant-garde de la République

El Guerrillero. Órgano de la Agrupación Guerrillera de Levante. Editado en las montañas levantinas

Heraldo de Aragón

L'Humanité. Organe central du PCF

Lucha. Boletin de FET y de las JONS

Le Monde

Mundo Obrero. Órgano del C.C. del PCE en España. Edición Regional de Aragón Nuestra Bandera. Revista Mensual de Orientación Política, Económica y Cultural Nueva España

Reconquista de España. Al Servicio de la JSUN

Reconquista de España. Órgano de la Delegación en París del Secretariado de UNE en Francia

Reconquista de España. Órgano de la UNE en Zona Norte

Reconquista de España. Organo de Unión Nacional de Todos los Españoles. Francia (z.o.)

Reconquista de España. Portavoz de la J.S. de U.N. Haute Vienne Reconquista de España. Suplemento de la Haute-Garonne Ruta. Organo de las Juventudes Libertarias de Cataluña y Baleares Solidaridad Obrera. Organo de la Confederación Nacional del Trabajo de Cataluña. AIT. Portavoz de la CNT de España 


\section{C) Fuentes orales (informantes)}

La mayoría de las personas consultadas aparecen citadas por sus iniciales para respetar su privacidad. En algunos casos, estas personas pidieron permanecer en un anonimato absoluto, y, por tanto, se citan como informantes anónimos.

Informante anónima. Fortanete, 21 de julio de 1997

Informante anónimo (guardia civil retirado). Graus, 16 de agosto de 1998

Informante anónimo (hombre de sesenta y ocho años). Rubielos de Mora, 1 de agosto de 1999 (entrevista realizada en colaboración con José Giménez Corbatón)

Tres informates anónimas. La Ginebrosa, 12 de noviembre de 1996

Agudo, Sixto. Alcampell, 22 de diciembre de 1995

A., F. Cantavieja, 15 de julio de 1997

A., J. Aguaviva, 13 de abril de 1997

A., R. Aguaviva, 13 de abril de 1997

A., R. Graus, 21 de agosto de 1998

Álvarez Canosa, Emilio. Greasque, 8 de octubre de 1996 (entrevista realizada y cedida por Eutimio Martín)

B., A. Aguaviva, 6 de agosto de 1996

B., E. Foz-Calanda, 25 de octubre de 1996

B., J. Cañada de Benatanduz, 26 de julio de 1997

B., L. Cantavieja, 22 de julio de 1997

B. M., J. Aguaviva, 6 de agosto de 1996

Buil, Josefina. Graus, 20 de agosto de 1998

Cañete, Alfonso. Ivry-sur-Seine, 18 de marzo de 1998

Coronas, Francisco. El Pueyo de Araguás, 26 de agosto de 1998

F., A. Guaso, 11 de agosto de 1998, y Aínsa, 12 de agosto de 1998

Fernández, Ángel. Toulouse, 8 de diciembre de 1998

G., L. Echo, 8 de mayo de 1999

Gimeno, Luis. Echo, 8 de mayo de 1999

Górriz, Manuel. Rubielos de Mora, 4 de enero de 1999 (entrevista realizada y cedida por José Giménez Corbatón)

Martínez, Amador. París, 17 de febrero de 1998

Martínez, Esperanza. Zaragoza, 22 de enero de 1995 y 9 de febrero de 1996

R., F. Aguaviva, 13 de abril de 1997

R. Z., L. Madrid, 27 de mayo de 2000

S., A. Aínsa, 12 de agosto de 1998

S., C. Morillo de Monclús, 25 de agosto de 1998 
S. G., L. (guardia civil retirado) Madrid, 26 de mayo de 1998

S., L. Castellote, 11 de agosto de 1997

Sanz, María. Béziers, 11 de febrero de 1998

Solé, Josefa. Villemomble, 7 de septiembre de 1999

T. C., F. Graus, 16 de agosto de 1998

V., A. Guaso, 11 de agosto de 1998

Z., P. Aguaviva, 6 de agosto de 1996

\section{D) Fuentes impresas}

AlBA, Víctor: Insomnie espagnole. Franc-Tireur, París, 1946.

Asile et travail aux Républicains espagnols. Pour la liquidation des camps de concentration. Résolutions de la Conférence Française d'aide aux Réfugiés espagnols. 10 et 11 juin 1939. Comité Français de coordination pour l'aide aux populations civiles de l'Espagne républicaine, París, 1939.

BAYO, Alberto: 150 preguntas a un guerrillero. s.i., s.l., 1960 (20. ${ }^{\mathrm{a}} \mathrm{ed}$. ).

Bergamín, José: La hija de Dios y la niña guerrillera. Manuel Altolaguirre, MéjiCo, 1945.

BoiXader, José V.: El «maquis». Page, Col. Hechos y hombres de la guerra, Madrid, 1944.

Conférence Internationale d'aide aux réfugiés espagnols. París, 1939.

Deux missions internationales visitent les camps de réfugiés espagnols (mai 1939).

Comité International de Coordination et d'Information pour l'aide à l'Espagne Républicaine, París, 1939.

Documentos inéditos para la historia del Generalísimo Franco. Fundación Nacional Francisco Franco, Madrid, 1992 (2 vols.).

García Pradas, J.: España, colonia de «su» ejército. Texto íntegro de la conferencia pronunciada en el Teatro Lanay, el día 27 de julio de 1947. Editado por la Federación local de París del MLE-CNT de España en Francia. Secretaría de Propaganda. París, 1947.

Hermanos, Juan: La fin de l'espoir. Témoignage. Gulliard, París, 1950.

Royo, Macario: Cómo implantamos el comunismo libertario en Mas de las Matas (Bajo Aragón). Iniciales, Barcelona, 1934. 


\section{E) Bibliografía}

1944: Les dossiers noirs d'une certaine Résistance. Trajectoires du fascisme rouge. Dossier réalisé par le groupe Puich Antich de la Fédération Anarchiste de Perpignan. Supplément à «Infos et analyses libertaires». Éditions du C.E.S, 1984.

ABAD BUIL, Irene, y José Antonio ANGULO: La tormenta que pasa y se repliega. Los años de los maquis en el Pirineo aragonés-Sobrarbe. Instituto de Estudios Altoaragoneses-PRAMES, Huesca, 2001.

Aguado SÁnchez, Francisco: El maquis en España. Librería Editorial San Martín, Madrid, 1975.

- El maquis en sus documentos. Librería Editorial San Martín, Madrid, 1976.

Agudo, Sixto: En la Resistencia francesa. Anubar, Zaragoza, 1985.

- Memorias. (La tenaz y dolorosa lucha por la libertad, 1939-1962). Instituto de Estudios Altoaragoneses, Huesca, 1991.

Aguilar Fernández, Paloma: Memoria y olvido de la guerra civil española. Alianza Editorial, Madrid, 1996.

AlAVI, Hamza: Las clases campesinas y las lealtades primordiales. Anagrama, Barcelona, 1976.

AlBA, Víctor: Historia de la resistencia antifranquista (1939-1955). Planeta, Barcelona, 1978.

L'Allemagne de Hitler. Introduction de François Bédarida. Éditions du Seuil, París, 1991.

ANDRIEU, Claire: «Les résistantes, perspectives de recherche», en Antoine Prost (dir.): La Résistance, une histoire sociale. Les Éditions de l'atélier / Éditions Ouvrières, París, 1997, pp. 69-96.

ARASA, Daniel: Años 40: los maquis y el PCE. Argos Vergara, Barcelona, 1984.

ARASANZ, Joaquín: Los guerrilleros. Ed. del autor, Huesca, 1994.

Aróstegui, Julio (ed.): Violencia y política en España, Ayer, n. ${ }^{\circ}$ 13, 1994.

Astray RIVAS, M.: Sindrome del 36: la IV Agrupación del Ejército de Galicia. Do Castro, La Coruña, 1992.

AzÉMA, J.P., y François BÉdARIDA: Vichy et les Français. Fayard, París, 1992.

AzPíroz PASCUAL, José M.a: «La II República en el Alto Aragón (1931-36)», Cuadernos CEHIMO, n. ${ }^{\circ}$ 21, 1994.

AzUAGA, José Antonio: La guerrilla antifranquista en Nerja. Izquierda Unida-Los Verdes-Convocatoria por Andalucía, Nerja, 1996.

Badoures, Anne-Marie, y Maurice Bouyou: La paysannerie en Perigord, 19401950. Le mascaret, Burdeos, 1983.

BARCIELA, Carlos: «Franquismo y corrupción económica», Historia Social, n. ${ }^{\circ} 30$, 1998, pp. 83-96. 
BARRULl, Jaume, y Conxita MIR (coords.): Violència politica i ruptura social a Espanya, 1936-1945. Espai-Temps, n. ${ }^{\circ}$ 23. Edicións de la Universitat de Lleida, Lérida, 1994.

BAYO, Eliseo: Los atentados contra Franco. Plaza y Janés, Barcelona, 1979.

BÉDARIDA, François: «L'histoire de la Résistance, lectures d'hier, chantiers de demain», Vingtième siècle. Revue d'Histoire, n. ${ }^{\circ}$ 11, 1986, pp. 75-90.

Berruezo, José: Contribución a la historia de la CNT de España en el exilio. Editores Mejicanos Unidos, Méjico, 1967.

Borrás, José: Políticas de los exiliados españoles, 1944-1950. Ruedo Ibérico, París, 1976.

- Del radical-socialismo al socialismo radical y libertario. Memorias de un libertario. Fundación Salvador Seguí, Madrid, 1998.

BROSSAT, Alain: Les tondues. Un carnaval moche. Manya, Levallois-Perret, 1992.

- Libération, fête folle. 6 juin 44-8 mai 45: mythes et rites ou le grand théatre des passions populaires. Autrement, París, 1994.

Broué, Pierre, y Raymond VaCheron: Meurtres au maquis. Grasset, París, 1997.

CASALLI, Luciano: «Introduzione. Il fascismo spagnolo», en Luciano Casali (ed.): Per una definizione della dittatura franchista. Franco Angeli, Milán, 1990, pp. 7-37.

CASANOVA, Julián: Anarquismo y revolución en la sociedad rural aragonesa, 19361938. Siglo XXI, Madrid, 1985.

- «Campesinado y colectivizaciones en Aragón: la lucha por el control de la revolución», en Julián Casanova (comp.): El sueño igualitario: campesinado y colectivizaciones en la España republicana, 1936-1939. Institución Fernando el Católico, Zaragoza, 1988, pp. 49-60.

- «Sociedad rural, movimientos campesinos y colectivizaciones. Reflexiones para un debate», en Julián Casanova (comp.): El sueño igualitario: campesinado y colectivizaciones en la España republicana, 1936-1939. Institución Fernando el Católico, Zaragoza, 1988, pp. 7-15.

- "Anarchism, Revolution and Civil War in Spain: The challenge of social History», International Review of Social History, XXXVII, 1992, pp. 398-404.

- Ángela Cenarro, Julita Cifuentes, M. ${ }^{a}$ Pilar Maluenda y M. ${ }^{a}$ Pilar SaloMÓN: El pasado oculto. Fascismo y violencia en Aragón (1936-1939). Siglo XXI, Madrid, 1992.

CASAS SÁNCHEZ, José Luis (coord.): La posguerra española y la segunda guerra mundial. Actas del seminario interdisciplinar celebrado en Córdoba del 6 al 10 de noviembre de 1989. Diputación de Córdoba, Córdoba, 1990.

CASTRO, Antón: El testamento de amor de Patricio Julve. Destino, Barcelona, 1994.

- Los seres imposibles. Destino, Barcelona, 1998. 
CatalÁ, Neus: Ces femmes espagnoles: de la Résistance a la Libération. Tirésias, París, 1994.

CENARRO, Ángela: El fin de la esperanza: fascismo y guerra civil en la provincia de Teruel (1936-1939). Instituto de Estudios Turolenses, Teruel, 1996.

- Cruzados y camisas azules. Los orígenes del franquismo en Aragón, 1936-1945, Prensas Universitarias de Zaragoza, Zaragoza, 1997.

- «Muerte y subordinación en la España franquista: el imperio de la violencia como base del "Nuevo Estado"”, Historia Social, n.o 30, 1998, pp. 18-19.

CERvera, Alfons: Maquis. Montesinos, s.l., 1997.

Chanfrault-Duchet, Marie: «Mitos y estructuras narrativas en la historia de vida: la expresión de las relaciones sociales en el medio rural», Historia y Fuente Oral, n. ${ }^{\circ}$ 4, pp. 11-21.

CHAVES, Julián: Huidos y maquis: la actividad guerrillera en la provincia de Cáceres (1936-1950). Institución cultural El Brocense, Cáceres, 1994.

Cicero, Isidro: Los que se echaron al monte: Juanin, Machado, Bedoya... Editora Popular, Madrid, 1977.

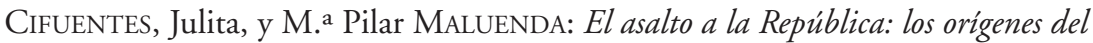
franquismo en la provincia de Zaragoza. Institución Fernando el Católico, Zaragoza, 1995.

Close, David H. (ed.): The greek civil war. Studies of polarization. Routledge, Londres y Nueva York, 1993.

Cobo Romero, Francisco: La guerra civil y la represión franquista en la provincia de Jaén (1936-1950). Diputación Provincial de Jaén, Jaén, 1993.

- Conflicto rural y violencia política. El largo camino hacia la dictadura. Jaén, 1917-1950. Universidad de Jaén, Jaén, 1998.

Cohen, Monique Lise, y Eric Malo (dirs.): Les camps du Sud-Ouest de la France. 1939-1944: Exclusion, internement et déportation. Privat, Toulouse, 1994.

Cointet-Labrousse, Michèle: Vichy et le fascisme. Les hommes, les structures et les pouvoirs. Complexe, Bruselas, 1987.

Colburn, Forrest D. (ed.): Everyday forms of Peasant Resistance. M.E. Sharpe, Nueva York, 1989.

Collectif Equipo Juvenil Confederal: La collectivité de Calanda. 1936-1938. La révolution sociale dans un village aragonais. Éditions CNT Région Parisienne, 1997.

Confederación Nacional del Trabajo de España. Regional de Aragón, Rioja y Navarra: Realizaciones revolucionarias y estructuras colectivistas de la comarcal de Monzón (Huesca). Con notas sobre la represión comunista. Ediciones Cultura y Acción, Monzón, 1977. 
CONSTANTE, Mariano: Los años rojos: españoles en los campos nazis. Martínez Roca, Barcelona, 1974.

- Republicanos aragoneses en los campos nazis: Mauthausen. Pirineo, Huesca, 2000.

Corbin, J.R.: The Anarchist Passion. Class in conflict in Southern Spain, 18101965. Avebury / Ashgate, Hants, Brooklyn, 1993.

Cordero, Inmaculada, y Encarnación LEMUS: «La malla de cristal: actividad política y vida de las comunistas andaluzas en la clandestinidad de los años cuarenta», Spagna Contemporanea, n. ${ }^{\circ}$ 15, 1999, pp. 101-120.

Cossías, Tomás: La lucha contra el maquis en España. Editora Nacional, Madrid, 1956.

CruZ, Rafael: Pasionaria. Dolores Ibárruri, historia y simbolo. Biblioteca Nueva, Madrid, 1999.

Cuesta Bustillo, Josefina (ed.): Memoria e Historia, Ayer, n.o 32, 1998.

DAmiano, Cipriano: La resistencia libertaria (1939-1970). Bruguera, Barcelona, 1978.

De Toro, Francisco Miguel: «Policía, denuncia y control social: Alemania y Austria durante el Tercer Reich", Historia Social, n. ${ }^{\circ} 34,1999$, pp. 117-134.

DELPLA, Claude: Les guerrilleros espagnols dans la zone Pyréneenne. Texto mecanografiado inédito, París, 1995.

Di FeBO, Giuliana: Resistencia y movimiento de mujeres en España, 1936-1976. Icaria, s.l., 1979.

Díaz Carmona, Antonio: Bandolerismo contemporáneo. Compi, Madrid, 1969.

Dreyfus-Armand, Geneviève: «Les oubliés», Hommes et migrations, n. ${ }^{\circ}$ 1148, nov. 1991, pp. 36-45.

- L'émigration politique espagnole en France au travers de sa presse, 1939-1975. Thèse d'État. Institut d'Études Politiques, París, 1994.

- «L'accueil des républicains espagnols en France: entre exclusion et utilisation, 1936-1940», Matériaux pour l'histoire de notre temps, n. ${ }^{\circ} 44$, oct.-dic. 1996, pp. 36-41.

- L'exil des républicains espagnols en France. De la guerre civile à la mort de Franco. Albin Michel, París, 1999.

- y Émile Témime: Les camps sur la plage, un exil espagnol. Autrement, París, 1995.

Dufour, Jean-Louis, y Rolande Trempé: «La France, base arriere d'une réconquete républicaine de l'Espagne: l'affaire du Val d'Aran», en Les Français et la guerre d'Espagne. Actes du colloque de Perpignan. C.R.E.P.F., Université de Perpignan, Perpinán, 1990, pp. 261-284.

- y Rolande TREMPÉ: El movimiento guerrillero de los años cuarenta. (Jornadas de estudio organizadas por la F.I.M. en colaboración con el Archivo Histórico del 
PCE y con el apoyo de la dirección general de Bellas Artes, celebradas en la sede de la FIM los dias 24, 25 y 26 de noviembre de 1988). FIM, Madrid, 1990.

Estruch Tobella, Joan: El PCE en la clandestinidad. 1939-1956. Siglo XXI, Madrid, 1982.

- Historia oculta del PCE. Temas de Hoy, Madrid, 2000.

European resistance movements 1939-1945. First International conference on the History of the Resistance Movements held at Liege-Bruxelles-Breendonk. September 1958. Pergamon Press, Londres, 1960.

EyChenne, Émilienne: Pyrénées de la Liberté: les évasions par l'Espagne, 19391945. Toulouse, Privat, 1998.

Fernández, A.E.: La España de los maquis. Era, Méjico, 1977.

Fernández Clemente, Eloy: "El maquis en Aragón», Andalán, n. ${ }^{\circ} 112,113$ y 114, mayo 1977.

Fernández Pancorbo, Paloma: El maquis al norte del Ebro. DGA, Zaragoza, 1988.

FERNÁNDEZ PRIETO, Lourenzo: «Represión franquista y desarticulación social en Galicia. La destrucción de la organización societaria campesina. 19361942», Historia Social, n. ${ }^{\circ}$ 15, invierno 1993, pp. 49-65.

FERnÁNDEZ VARGaS, Valentina: La resistencia interior en la España de Franco. Istmo, Madrid, 1981.

Fink, Carole: Marc Bloch: A life in History. Cambridge University Press, Nueva York, 1989.

FiтtKo, Lisa: De Berlín a los Pirineos. Evocación de una militancia. Anaya / Mario Muchnik, Madrid, 1997.

FOLGUERA, Pilar: «La construcción de lo cotidiano durante los primeros años del franquismo", en Luis Castells (ed.): La historia de la vida cotidiana, Ayer, n. ${ }^{\circ}$ 19, 1995, pp. 135-164.

FONT, Christian: «Les paysans et la Résistance, le modèle aveyronnais?», en La résistance et les Français. Enjeux stratégiques et environnement social. Presses Universitaires de Rennes, Rennes, 1995, pp. 175-189.

FonTANA, Josep (ed.): España bajo el franquismo. Crítica, Barcelona, 1986.

FRASER, Ronald: Recuérdalo tú y recuérdalo a otros. Historia oral de la guerra civil española. Crítica, Barcelona, 1976.

- «La historia oral como historia desde abajo», en Pedro Ruiz Torres (ed.): La historiografía, Ayer, n. ${ }^{\circ}$ 12, 1993, pp. 79-92.

GARCÍA Delgado, José Luis (ed.): El primer franquismo. España durante la segunda guerra mundial. Siglo XXI, Madrid, 1989.

GARCÍA ReIGOSA, Carlos: El regreso de los maquis. Júcar, Madrid, 1992.

- La agonía del león. Alianza Editorial, Madrid, 1995. 
GASCÓN, Antonio: «1944: la "Reconquista" empieza en los Pirineos», Historia y Vida, extra n. ${ }^{\circ}$ 81, 2. ${ }^{\circ}$ trimestre de 1996, pp. 79-83.

GERMÁn, Luis: Aragón en la Segunda República. Estructura económica y comportamiento político. Institución Fernando el Católico, Zaragoza, 1984.

Giménez Conbatón, José: El fragor del agua, Anaya / Mario Muchnik, Madrid, 1993.

- Tampoco esta vez dirían nada. Anaya / Mario Muchnik, Madrid, 1997.

GÓmez Fouz, J.R.: Bernabé (el mito de un bandolero). Silverio Cañada, Gijón, 1989.

GÓMEZ PARRA, Rafael: La guerrilla antifranquista, 1945-1949. Revolución, Madrid, 1983.

GONZÁlEZ, Juan José: Muerte y pasión de un maquis: Sebastián Eulogio Moya «El Chichango»: un drama obligado. Ed. del autor, s.l., 1985.

GONZÁlez CALleja, Eduardo: «Violencia política y represión en la España franquista: consideraciones teóricas y estado de la cuestión», en Roque Moreno y Francisco Sevillano (eds.): El franquismo Visiones y balances. Publicaciones de la Universidad de Alicante, Alicante, 1999, pp. 119-150.

GonZÁlez MARTíneZ, Carmen: «Sobrevivir a la represión franquista: condiciones de vida y trabajo de represaliados murcianos», en J.M. Trujillano y José M. ${ }^{a}$ Gago (eds.): Historia y fuentes orales. Historia y memoria del franquismo. 1936-1978. Actas de las IV Jornadas. Fundación Cultural Santa Teresa, Ávila, 1997, pp. 425-437.

Grando, René, Jaques Queralt y Xavier Febrès: Camps du mépris. Des chemins de l'exil à ceux de la Résistance (1939-1945). 500000 républicains d'Espagne «indésirables» en France. Llibres del Trabucaire, Perpinyà, 1991.

Gros, José: Abriendo camino. Relato de un guerrillero comunista. Prólogo de Dolores Ibárruri. Librairie du globe, París, 1971.

Guidez, Guylaine: Femmes dans la guerre, 1939-1945. Perrin, París, 1989.

Guillon, Jean-Marie: «Le maquis, une résurgence du banditisme social?», Provence historique, n. ${ }^{\circ} 147,1986$, pp. 57-67.

- «La Résistance au village», en La Résistance et les Français. Enjeux politiques et environnement social. Presses Universitaires de Rennes, Rennes, 1995, pp. 233-243.

- y Pierre LABORIE (dirs.): Mémoire et Histoire: la Résistance. Privat, Toulouse, 1995.

- y Robert Mencherini (dirs.): La Résistance et les européens du Sud. L'Harmattan, París, 1999.

HARDING, Susan: Rehacer Ibieca. La vida rural en Aragón en los tiempos de Franco. Instituto Aragonés de Antropología, Zaragoza, 1999 (1. ${ }^{a}$ ed., 1984). 
HeIne, Hartmut: A guerrilla antifranquista en Galicia. Xerais, Vigo, 1980.

- La oposición politica al franquismo. De 1939 a 1952. Crítica, Barcelona, 1983. Historias de maquis en el Pirineo aragonés. Pirineum Editorial, Jaca, 1999.

HовSBAWм, Eric J.: Rebeldes primitivos. Estudio sobre las formas arcaicas de los movimientos sociales en los siglos XIX y XX. Ariel, Barcelona, 1968.

- Los campesinos y la política. Anagrama, Barcelona, 1976.

- Bandidos. Ariel, Barcelona, 1976.

Housden, Martyn: Resistance and conformity in the Third Reich. Routledge, Londres y Nueva York, 1997.

IATRIDES, John O., y Linda WrigLey (eds.): Greece at the crossroads. The civil war and its legacy. The Pensylvannia State University Press, University Park, 1995.

Jardón, Xoán Xosé, M.a José López Álvarez y Raúl Soutelo: “"¡Eu tamén son vella e recordo!”. La fuente oral en la recuperación del pasado: reflexiones metodológicas para una historia sociocultural», Espacio, tiempo y forma, serie V, H. ${ }^{a}$ Contemporánea, t. 11, 1998, pp. 343-364.

Jarne Modol, Antonieta, y Joan SANGÜÉs SAN José: «Una historia oral de la guerra civil y la lucha clandestina en el primer franquismo: Lleida 19361945», en J.M.Trujillano y José M. a Gago (eds.): Historia y fuentes orales. Historia y memoria del franquismo. 1936-1978. Actas de las IV Jornadas. Fundación Cultural Santa Teresa, Ávila, 1997, pp. 363-376.

Joutard, Philippe: Ces voix qui nous viennent du passé. Hachette, s.l., 1983.

- «El testimonio oral y la investigación histórica francesa, ¿progreso o declive?», Historia y Fuente Oral, n. ${ }^{\circ}$ 14, 1995, pp. 65-79.

JUDT, Tony (ed.): Resistance and revolution in Mediterranean Europe, 1939-1948. Routledge, Londres, 1989.

Julí́, Santos (coord.): Víctimas de la guerra civil. Temas de Hoy, Madrid, 1999.

KAISER, Carlos J.: La guerrilla antifranquista. Historia del maquis. Ed. 99, Madrid, 1976.

KéDROS, André: La Résistance grecque (1940-1944). Robert Laffont, París, 1966.

KeDward, H.R.: Naissance de la Résistance dans la France de Vichy. Idées et motivations, 1940-1942. Ed. Champ Vallon, Seyssel, 1989.

- In search of the maquis: Rural resistance in Southern France, 1942-1944. Clarendon Press, Oxford, 1994.

Kelsey, Graham: Anarcosindicalismo y Estado en Aragón. 1930-1938. Fundación Salvador Seguí / Institución Fernando el Católico, 1994.

KREBS, Gilbert, y Gérard SCHNELIN (eds.): Exil et Résistance au National-Socialisme, 1933-1945. Publications de l'Institut d'Allemand / Université de la Sorbonne Nouvelle, Asnières, 1998. 
LAMELA, V.L.: "Foucellas»: El riguroso relato de una lucha antifranquista (19361952). Do Castro, La Coruña, 1992.

LECLERC, Françoise, y Michèle WeINDLING. «La répression des femmes coupables d'avoir collaboré pendant l'occupation", Clio. Histoire, femmes et sociétés. N. ${ }^{\circ}$ 1: Résistances et Libérations. Coordiné par Françoise Thébaud. Presses Universitaires du Mirail, Toulouse, 1995, pp. 129-150.

LEDESMA, José Luis: «Asalto al pasado y revolución: la represión republicana en la provincia de Zaragoza durante la guerra civil», Rolde. Revista de Cultura Aragonesa, n. ${ }^{\circ}$ 88-89, abril-septiembre 1999, pp. 5-19.

LinZ, J.J.: «Una teoría del régimen autoritario. El caso de España», en Stanley G. Payne: Politica y sociedad en la España del siglo XX. Akal, Madrid, 1978, pp. 205-263.

LotTMAnN, Herbert: La depuración. Tusquets, Barcelona, 1998.

LUEBBERT, Gregory M.: Liberalismo, fascismo o socialdemocracia. Clases sociales y orígenes politicos de los regímenes de la Europa de entreguerras. Prensas Universitarias de Zaragoza, Zaragoza, 1997.

LÜTDKE, Alf: «De los héroes de la Resistencia a los coautores. "Alltagsgeschichte" en Alemania", Ayer, n. ${ }^{\circ}$ 19, 1995, pp. 49-69.

Máiz, Bernardo: Galicia na Segunda República e baixo o franquismo (1930-1976). Xerais, Vigo, 1988.

MALEFAKIS, Edward: Reforma agraria y revolución campesina en la España del siglo XX. Ariel, Barcelona, 1976.

MALERBE, Pierre: La oposición al franquismo, 1939-1975. Naranco, Madrid, 1977.

MARCOT, François: «Les payans et la Résistance: problèmes d'une approche sociologique», La Résistance et les Français. Enjeux stratégiques et environnement social. Presses Universitaires de Rennes, Rennes, 1995, pp. 245-255.

- «Pour une sociologie de la Résistance: Intentionnalité et fonctionnalité», en Antoine Prost (dir.): La Résistance, une histoire sociale. Les éditions de l'atélier / Éditions ouvrières, París, 1997, pp. 21-41.

Martínez de Baños CARRILlo, Fernando: Vida y exilio de "otros" comunistas españoles en Francia. Una cultura de la resistencia. 1936-1975. Memoria de licenciatura. Universidad de Zaragoza, Zaragoza, 1999.

Martínez López, Francisco: Guérrillero contre Franco. Syllepse, París, 2001.

Memorias del olvido. La contribución de los republicanos españoles a la Resistencia y a la Liberación de Francia. F.A.C.E.E.F., París, 1996.

Michel, Henri: Histoire de la Résistance en France (1940-1944). PUF, París, 1969.

Milza, Pierre: Les fascismes. Éditions du Seuil, París, 1991.

Molina, J.M.: El movimiento clandestino en España. 1939-1949. Editores Mexicanos Unidos, Méjico, 1976. 
Molinero, Carmen: «Mujer, franquismo, fascismo. La clausura forzada en un mundo pequeño", Historia Social, n. ${ }^{\circ} 30,1998$, pp. 97-117.

MOORE, Barrington: Los orígenes sociales de la dictadura y la democracia. El señor y el campesino en la configuración del mundo moderno. Península, Barcelona, 1976.

Morán, Gregorio: Miseria y grandeza del Partido Comunista de España, 19391985. Planeta, Barcelona, 1986.

MORENO GOMEZ, Francisco: Córdoba en la posguerra (la represión y la guerrilla, 1939-1950). Francisco Baena, Córdoba, 1987.

- La resistencia contra Franco. Crítica, Barcelona, 2001.

NAREDO, José Manuel: La evolución de la agricultura en España (1940-1990). Servicio de Publicaciones de la Universidad de Granada, Granada, 1996.

NiCOLÁs, Encarna: «Los poderes locales y la consolidación de la dictadura franquista», en Glicerio Sánchez Recio: El primer franquismo (1936-1959), Ayer, n. ${ }^{\circ} 33,1999$, pp. 65-85.

- y Alicia Alted: Disidencias en el franquismo. Diego Marín, Murcia, 1999.

NoguÈres, Henri: Histoire de la Résistance française. R. Laffont, París, 4 tomos en 1967, 1969, 1972 y 1976.

NOLTE, Ernst: La crisis del sistema liberal y los movimientos fascistas. Península, Barcelona, 1971.

La oposición libertaria al régimen de Franco. Memorias de las III Jornadas Internacionales de Debate Libertario. Fundación Salvador Seguí, Valencia y Madrid, 1993.

ORTIZ, Jean: «La résistance espagnole en Béarn», en Les Espagnols et la guerre civile. Atlantica, Biarritz, 1999, pp. 379-409.

ORTIZ HeRAS, Manuel: Violencia política en la II República y el primer franquismo. Siglo XXI, Madrid, 1996.

OrTiZ-Osés, Andrés: La identidad cultural aragonesa. Centro de Estudios Bajoaragoneses, Alcañiz, 1992.

Payne, Stanley G.: El régimen de Franco, 1936-1975. Alianza Editorial, Madrid, 1987.

Peiró, Antonio: «Los orígenes del fascismo: Falange Española en Teruel y Bajo Aragón (1933-1937)», en Actas del Encuentro sobre historia contemporánea de las tierras turolenses. Diputación Provincial de Teruel, Teruel, 1986.

Pérez Regordán, Manuel: El maquis en la provincia de Cádiz: única provincia que ha conseguido aunar lo oficial con lo anecdótico. Ed. del autor, Sevilla, 1987.

PeSCHANSKY, Denis: «Les espagnols dans la Résistance», en Philip Joutard y François Marcot (dirs.): Les étrangers dans la Résistance en France. Musée de la Résistance et de la Déportation, Bésançon, 1993, pp. 62-66. 
PIKE, David Wingeate: Vae victis! Los republicanos españoles refugiados en Francia, 1939-1944. Ruedo Ibérico, París, 1969.

- Jours de gloire, jours de honte. Le parti communiste d'Espagne en France depuis son arrivée en 1939 jusqu'à son départ en 1950. C.D.U. I SEDES, París, 1984.

- In the service of Stalin. The Spanish Communists in Exile, 1939-1945. Oxford University Press, Oxford, 1993.

PONS, Francisco: Barbelès à Argelès et autour d'autres camps. L'Harmattan, París, 1993.

PONS PRADES, Eduardo: Republicanos españoles en la segunda guerra mundial. Planeta, Barcelona, 1975.

- Guerrillas españolas. 1936-1960. Planeta, Barcelona, 1977.

PONZÁN VIDAL, Pilar: Lucha y muerte por la libertad. Memoria de 9 años de guerra: 1936-1945. Ed. de la autora, s.l., 1996.

Prada Rodríguez, Julio: «Las mujeres de los escapados: aproximación al papel de las mujeres como soporte material de la resistencia antifranquista", en Las mujeres y la guerra civil española. III Jornadas de Estudios Monográficos. Salamanca, octubre de 1989. Ministerio de Cultura, Madrid, 1991, pp. 218-223.

PRESTON, Paul: «La oposición antifranquista: la larga marcha hacia la unidad», España en crisis. FCE, Méjico, 1977, pp. 217-263.

- La política de la venganza. El fascismo y el militarismo en la España del siglo XX. Península, Barcelona, 1997.

Pro Ruiz, Juan: «Las élites en la España liberal: clases y redes en la definición del espacio social (1808-1931)», Historia Social, n. ${ }^{\circ} 21$, 1995, pp. 47-69.

RAFANEAU-BOJ, Marie-Claire: Los campos de concentración de los refugiados españoles en Francia (1939-1945). Omega, Barcelona, 1995.

Ramos, M. ${ }^{a}$ Dolores, y Francisco Javier Pereira: «El matrimonio del cielo y el infierno. Una alegoría de la vida cotidiana en el franquismo (1939-1952)», en Concepción Campos Luque y M. ${ }^{a}$ José González Castillejo (coords.): Mujeres y dictaduras en España y América: el largo camino. Universidad de Málaga, Málaga, 1996, pp. 123-147.

Reguant, José M.a: Marcelino Massana: ¿Terrorismo o resistencia? Dopesa, Barcelona, 1979.

Reguillón García, Adolfo Lucas (Severo Eubel de la Paz): El último guerrillero de España. AGLAG, Madrid, 1975.

Rencontre Guerre d'Espagne et immigration espagnole. VO éditions, Toulouse, 1997.

RICHARDS, Michael: Un tiempo de silencio. La guerra civil y la cultura de la represión en la España de Franco, 1936-1945. Crítica, Barcelona, 1999. 
RICHARDS, Michael: «Guerra civil, violencia y la construcción del franquismo», en Paul Preston (ed.): La República asediada. Hostilidad internacional y conflictos internos durante la Guerra Civil. Península, Barcelona, 1999, pp. 201238.

RIPA, Yannick: «Armes d'hommes contre femmes désarmées: de la dimension sexuée de la violence dans la guerre civile espagnole», en Cécile Dauphin y Arlette Farge (dirs.): De la violence et des femmes. Albin Michel, París, 1997, pp. 131-145.

- «Le mythe de Dolores Ibárruri», en Catherine Marrand-Fouquet (coord.): Clio. Histoire, femmes, sociétés. N. o 5: Guerres Civiles, 1997, pp. 147-155.

Romeu, Fernanda: Más allá de la utopía: la Agrupación Guerrillera de Levante. Alfons el Magnànim, Valencia, 1987.

- El silencio roto. Mujeres contra el franquismo. Ed. de la autora, s.l., 1994.

RoYo, Macario: Cómo implantamos el comunismo libertario en Mas de las Matas. Iniciales, Barcelona, 1934.

ROZADA, Nicanor: ¿Por qué sangró la montaña? La guerrilla en los montes de Asturias. Ed. del autor, Oviedo, 1988.

RUIZ CARNICER, Miguel Ángel: «Poder político y respuesta social en el Bajo Aragón en el primer franquismo", en Pedro Rújula (coord.): Entre el orden de los propietarios y los sueños de rebeldía. El Bajo Aragón y el Maestrazgo en el siglo XX. Grupo de Estudios Masinos, s.l., 1997.

SABIO, Alberto: Los montes públicos en Huesca (1859-1930): El monte no se improvisa. Instituto de Estudios Altoaragoneses, Huesca, 1997.

SaCaluga, José Antonio: La resistencia socialista en Asturias (1937-1962). Pablo Iglesias, Madrid, 1986.

SAlOMÓN, M. a Pilar: «La guerra civil en el Alto Aragón y sus consecuencias», Cuadernos CEHIMO, n. ${ }^{\circ} 21,1994$, pp. 277-288.

SAMUEL, Raphael: Historia popular y teoría socialista. Crítica, Barcelona, 1984.

SÁnchez Agustí, Ferrán: Maquis a Catalunya. De la invasió de la Vall d'Arán a la mort del Caracremada. Pagès editors, Lérida, 1999.

SÁNCHEZ BRUN, Gaudioso: "Aportaciones documentales para el estudio del maquis en la provincia de Teruel». Turia, n. ${ }^{\circ}$ 9, 1985, pp. 203-226.

- «Falange y administración local en el Bajo Aragón y las cuencas mineras turolenses (1938-1960)», en Pedro Rújula (coord.): Entre el orden de los propietarios y los sueños de rebeldía. El Bajo Aragón y el Maestrazgo en el siglo XX. Grupo de Estudios Masinos, s.l., 1997.

SCOTT, James C.: Weapons of the weak. Everyday forms of peasant resistance. Yale University Press, New Haven, 1985.

— «Formas cotidianas de rebelión campesina», Historia Social, n. ${ }^{\circ} 38,1997$, pp. 13-39. 
SEMELIN, Jacques: Sans armes face à Hitler: La résistance civile en Europe, 19391943. Payot, París, 1989.

SERRANO, Secundino: La guerrilla antifranquista en León (1936-1951). Junta de Castilla y León, Valladolid, 1986.

- Maquis. Historia de la guerrilla antifranquista. Temas de Hoy, Madrid, 2001.

SeVIlla-GuZmán, Eduardo: La evolución del campesinado en España. Península, Barcelona, 1979.

SHANIN, Theodor: La clase incómoda. Sociología politica del campesinado en una sociedad en desarrollo (Rusia, 1910-1925). Alianza Editorial, Madrid, 1983.

- (ed.): Peasants and peasant society: selected readings. Oxford, Blackwell, 1987 (2..$^{\mathrm{a}}$ ed.).

SOREL, Andrés: Búsqueda, reconstrucción e historia de la guerrilla española del siglo $X X$ a través de sus documentos, relatos y protagonistas. Librairie du Globe, París, 1970.

Soriano, Antonio: Exodos. Historia oral del exilio republicano en Francia, 19391945. Crítica, Barcelona, 1989.

StRobL, Ingrid: Partisanas. La mujer en la resistencia contra el fascismo y la ocupación alemana (1936-1945). Virus, Barcelona, 1996.

SOUTElo VÁzQuez, Raúl, y Alfredo VARela SABAS: «Variaciones en las formas de represión y resistencia popular en el mundo rural ourensano. 1936-1946”, en José M. ${ }^{a}$ Trujillano y José M. ${ }^{a}$ Gago (eds.): Historia y fuentes orales. Historia y memoria del franquismo. 1936-1978. Actas IV Jornadas. Fundación Cultural Santa Teresa, Ávila, 1997, pp. 217-233.

TÉLleZ, Antonio: La guerrilla urbana en España: Facerías. Ruedo Ibérico, París, 1974.

- Sabaté. Guerrilla urbana en España (1945-1960). Plaza y Janés, Barcelona, 1978.

- La red de evasión del grupo Ponzán. Anarquistas en la guerra secreta contra el franquismo y el nazismo (1936-1944). Virus, Barcelona, 1996.

TÉMIME, Émile: «Problèmes stratégiques des guerrilleros et de la guérrilla espagnole dans la Résistance en France», en François Marcot (dir.): La Résistance et les Français. Lutte armée et maquis. Actes du Colloque international de Besançon, 15-17 juin 1995. Annales littéraires de l'Université du FrancheComté, 1996, pp. 269-278.

Thalmann, Rita (dir.): Femmes et fascismes. Tierce, París, 1986.

THÉBAud, Françoise (coord.): Clio. Histoire, femmes et sociétés. N.o 1: Résistances et Libérations. Presses Universitaires du Mirail, Toulouse, 1995.

ThOmpson, Paul: La voz del pasado. Alfons el Magnànim, Valencia, 1988.

- «Historias de vida en el análisis del cambio social», en La Historia oral: métodos y experiencias. Debate, Madrid, 1993. 
TiLLON, Charles: Les FTP. Julliard, París, 1962.

TORBADO, Jesús, y Manuel LeguineChE: Los topos. El testimonio estremecedor de quienes pasaron su vida escondidos en la España de posguerra. El País / Aguilar,

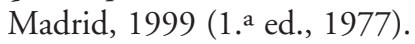

TREMPÉ, Rolande: «La 35 Brigade Marcel Langer (Toulouse)», en Philippe Joutard y François Marcot (dirs.): Les étrangers dans la Résistance en France. Musée de la Résistance et de la Déportation, Bésançon, 1993, pp. 116-119. TuSELL, Javier: La oposición democrática al franquismo. Planeta, Barcelona, 1977.

- La dictadura de Franco. Alianza Editorial, Madrid, 1988.

UGARTE, Javier: La nueva Covadonga insurgente. Orígenes sociales y culturales de la sublevación de 1936 en Navarra y el País Vasco. Biblioteca Nueva, Madrid, 1998.

VÁZquez Montalbán, Manuel: Crónica sentimental de España. Grijalbo, Barcelona, 1998 (1. a ed., 1971).

Venner, Dominique: Histoire critique de la Résistance. Pygmalion, París, 1995.

VIDAL SALES, J.A.: Después del 39. La guerrillla antifranquista. ATE, Barcelona, 1976.

VILA, Justo: La guerrilla antifranquista en Extremadura. Universitas, Badajoz, 1986.

Villar Raso, Manuel: La Pastora. El maqui hermafrodita. Albia Ediciones, 1978.

Villegas, Jean-Claude: Plages d'exil. Les camps de réfugiés espagnols en France1939. BDIC, Nanterre, 1989.

WeITZ, Margaret Collins: Sisters in the Résistance: how women fought to free France, 1940-1945. Wiley, Nueva York, 1995.

WOLF, Eric: Las luchas campesinas del siglo XX. Siglo XXI, Madrid, 1979.

YUSTA, Mercedes: «Un mito de la guerrilla en Aragón: la Pastora», Arenal. Revista de Historia de las Mujeres, vol. 5, n. ${ }^{\circ}$ 2, julio-dic. 1998, pp. 361-377.

- La guerra de los vencidos. El maquis en el Maestrazgo turolense, 1940-1950. Institución Fernando el Católico, Zaragoza, 1999.

- «Un pasado sin huella: los campos de concentración de los republicanos españoles en Francia», en Congreso 60 años después. La España exiliada de 1939, celebrado en Huesca del 27 al 29 de octubre de 1999.

- «Los maquis de Andorra: la pervivencia de la memoria», Revista de Andorra, n. ${ }^{\circ} 1$, diciembre 2000, pp. 77-88.

- «La mémoire collective de la Seconde République dans les milieux rurales des années 40", en Marie-Claude Chaput et Thomas Gomez (dirs.): Histoire et mémoire de la Seconde République espagnole, Presses de l'Université Paris X, París, 2002, pp. 465-472.

- «El maquis», en Historia ilustrada de la provincia de Teruel. Fundación para la información de Teruel, Teruel, 2002. 



\section{SIGLAS}

AGA Archivo General de la Administración

AGAA Agrupación Guerrillera del Alto Aragón

AGE Agrupacion de Guerrilleros Españoles

AGLA Agrupación Guerrillera de Levante y Aragón

AHN Archivo Histórico Nacional

AHPH Archivo Histórico Provincial de Huesca

AHPT Archivo Histórico Provincial de Teruel

ANFD Alianza Nacional de Fuerzas Democráticas

BBC British Broadcasting Corporation

CDL Comité départamental de libération

CEDA Confederación Española de Derechas Autónomas

CFLN Comité français de libération nationale

CGTU Confederación General de Trabajadores Unidos

CNR Conseil national de la Résistance

CNS Central Nacional Sindical

CNT Confederación Nacional de Trabajadores

CTE Compañías de Trabajadores Extranjeros

DGS Dirección General de Seguridad

DNP Delegación Nacional de Provincias

EAM Frente Nacional Griego de Liberación

EDES Unión Nacional Griega Democrática

ELAS Ejército Nacional Griego de Liberación

EKKA Movimiento de Liberación Nacional y Social

FAI Federación Anarquista Ibérica

FET-JONS Falange Española Tradicionalista y de las Juntas Ofensivas Nacional-sindicalistas

FETE Federación Española de Trabajadores de la Enseñanza 
FFI Forces françaises de l'intérieur

FNTT Federación Nacional de Trabajadores de la Tierra

FTP Franc-Tireurs et partisans

GTE Groupes de travailleurs étrangers

JARE Junta de Asistencia a los Republicanos Españoles

JEL Junta Española de Liberación

JSUN Junta Suprema de Unión Nacional

MAOC Milicias Antifascistas de Obreros y Campesinos

MLE Movimiento Libertario Español

MOI Main-d'oeuvre immigrée

MUR Mouvements unifiés de la Résistance

ONU Organización de Naciones Unidas

OS Organisation spéciale

PCE Partido Comunista de España

PCF Parti communiste français

POUM Partido Obrero de Unificación Marxista

PSOE Partido Socialista Obrero Español

SERE Servicio de Evacuación de Refugiados Españoles

SFIO Section française de l'International ouvrière

SIEP Servicio de Información Especial Periférico

SIGC Servicio de Información de la Guardia Civil

SOE Special Operations Executive

STO Service du travail obligatoire

UGT Unión General de Trabajadores

UHP Unión de Hermanos Proletarios

UME Unión de Mujeres Españolas

UNE Unión Nacional Española 


\section{ÍNDICE ALFABÉTICO}

Acción Católica Femenina: 234

Acevedo (coronel): 92

$\mathrm{AD}$ : véase $A N F D$

Adahuesca: 194

AEVIHM, colectivo: $235 \mathrm{n}$.

África: 64, 93

AGAA: véase Agrupación Guerrillera del Alto Aragón

Agde: 63

AGE: véase Agrupación de Guerrilleros Españoles

AGLA: véase Agrupación Guerrillera de Levante y Aragón

Agrupación de Guerrilleros Españoles (AGE): 80, 81, 84, 85, 87, 88, 91, 92, 109n.

Agrupación Femenina Pasionaria: 237

Agrupación Guerrillera de Levante y Aragón (AGLA): 6, 76n., 95, 118, 119 y n., 128, 129, 130 y n., 131, $132,133,134,135,136,137,138$ y n., 139 y n., 145, 146 y n., 147 y n., 149-154, 155 y n., 156 y n., 157, $163,166,171$ y n., 172n., 175, 177180, 183 y n., 184-188, 191, 193, 218, 219, 226, 231, 236, 238n., 240n., 241 y n., 248

Agrupación Guerrillera del Alto Aragón (AGAA): 108, 126, 139, 140, 141 y n., 142, 143, 146, 149, 151, 152,
157-159, 161, 162, 192-194, 227, 231, 236

Agrupación guerrillera Reconquista de España: 91, 92

Aguado Sánchez, Francisco: 5, 6n.

Aguanta: véase Gálvez, Manuel

Aguaviva: 107, 119, 124, 125, 131, 133, 137, 167, 168, 174, 178, 179, 218, 220,222

Agudo, Sixto: 9, 71, 72 y n., 73 y n., 74, 79 y n., 81, 108 y n.

Agüero (sierras): 118, 157

Agüero: 108, 148

Águila (pantano): 77, 78, 81

Aguilar, José: 220

Aísa: 108

Alavi, Hamza: 19 y n.

Albalate de Cinca: 235

Albarracín (sierra): 130, 153

Albatera: 131, 132

Albelda: 162

Albentosa: 168, 172n., 239, 240n.

Alborge: 195, 206

Alcalá de Gurrea: 50n.

Alcalá de la Selva: 47, 168, 171, 189, 191, 211

Alcanar: 188

Alcañiz: 116, 126, 130, 210, 211, 218n., 235

Alcázar de San Juan: 213 
Alcira: 131

Alcolea: 162

Alcón, Pablo: 48

Alcorisa: 47, 235

Alcubierre (sierra): 120

Aldealcorvo: 130

Aldehuela: 204

Alemania: VII, 26, 29, 32, 34, 42, 67 y n., 69, 71, 123, 199n.

Alfredo: véase Fuertes Vidosa, Ángel

Aliaga: 123, 125n., 130, 173, 191, 203, 211

Alianza Democrática $(\mathrm{AD})$ : véase Alianza Nacional de Fuerzas Democráticas

Alianza Nacional de Bronchales: 175

Alianza Nacional de Fuerzas Democráticas (ANFD): 73, 86, 87, 103, 104, $144,145,147,148,155$

Alicante: 131, 217

Almazán Soriano, Ramón: 175n.

Almería (provincia): 163

Almudévar: 50n.

Almunia, La (partido judicial): 224

Almunias, Las: 141, 152

Alpuente Caballero, José: 175n.

Alpuente Sánchez, Felipe: 175n.

Alquézar: 140, 192

Altaba, Fabián: 164

Alto Aragón: 108, 109, 111, 192, 193, 216

Alto Garona (departamento): 82, 91, 98, 163

Altorrincón: 144

Altos Pirineos (departamento): 110, 163

Álvarez, Julia: 101

Álvarez Canosa, Emilio (Pinocho): 94, 95, 96

Álvarez del Vayo, Julio: 101

Allepuz: 123

Amelang, James S.: 240n.

América Latina: 211

Americano: 152, 192

Améry, Jean: VIII
Amorrortu, Germán (Manso): 95 y n., 129, 155, 156n., 178, 179, 180n., 183,184

Amparo: 84

Andalucía: 4, 24, 107, 150, 236

Andorra: 227

Andorra (principado): 98

Andrés: véase Galarza, Vicente

Andrieu, Claire: 83n.

ANFD: véase Alianza Nacional de Fuerzas Democráticas

Ansó: 50n.

Ansó (valle): 79

Antón, Francisco: 70

Antonio: véase Fuertes Vidosa, Angel

Anzánigo: 115

Aragón: IX, X, 4, 6, 7n., 11, 12, 17, 19, $24,32,45,50,59,60,72,98,102$, $107,115,116,126,130,139-142$, 149, 160n., 161n., 162n., 165, 180, 188, 195, 197 y n., 200, 211, 215 y n., 217, 224, 225n., 234n., 235, $236,243,246,249,250$

Aragón (valle): 79

Aragüés: 115

Arán (valle): 4, 9, 85, 91, 93, 94, 95, 96 y n., 97n., 100, 101, 107, 111, 115, 247

Arañones, Los (estación internacional de Canfranc): 100

Arasa, Daniel: 93, 96n., 109n.

Arasanz, Joaquín (comandante Villacampa): 109, 111, 112, 118, 139, $140 \mathrm{y}$ n., 141, 143, 144-147, 149, 151, 157, 158, 160n., 161n., 162n., 202

Aratorés: 115

Arcede, Jesús: véase Caellas Aymerich, Jesús

Arcede, Juan: 133

Arcusa: 143

Ardanuy Bardají, Antonio: 119

Ardate: 115

Ardisa: 148 
Argel: 80

Argelès-sur-Mer: 63, 64, 71, 72

Argelia: 64

Ariège (departamento): 73, 77, 78, 88, 91, 98, 108, 168

Ariza: 116

Armée secrète: 34, 62

Armendáriz, Montxo: X

Arrieta, Lina: 83

Ascaso, Francisco: 195n.

Aspe (valle): 79

Asturias: 4, 107, 157, 158

Asturias: 119

Aude (departamento): 72, 73, 78, 140, 163

Auschwitz: VIII, XI

Austria: 26, 68, 199n.

Ávila (provincia): 163

Ayerbe: 50n.

Azcárate: 92

Aznárez, Manuel: 120

Azuara: 119, 121

Bada, Federico: 155 y n., 169

Bagnères de Bigorre: 79

Bailo: 50n.

Bajo Aragón: 46, 210

Bajos Pirineos (departamento): 79, 91, 100, 163

Balcanes: 40

Baldellou: 146n., 162

Balio Gracia, José: 118

Ballester Planas, Tomás: 122n.

Barbastro: 125, 143, 144, 152, 193, 235

Barbenuta: 50n.

Barbès: 32

Barbuñales: 162, 193

Bárcabo: 194

Barcarès: 66n.

Barcelona: 3, 5, 55, 70, 133, 191, 195, 203

Barciela, Carlos: 59 y n.

Barcos, José: 111
Barga, Corpus: 86

Barquero, Jerónimo: 175

Barracas: 172n., 240n.

Barrado, Javier: 236n.

Bas Aguado, Francisco (Pedro): 183, 184, 186

Baudelaire, Charles: XI

Bayona: 85

Bayot, Narciso: 48

Bearn: 79

Beceite (montes): 116

Bédarida, François: 31 y n., 32 y n., 42 n.

Beltrán, Antonio (Esquinazau): 78, 150, 151, 153, 154 y n., 158

Bella, Antonio: 48

Bellostas, Ángel: 144 y n., 151, 158, $159,162,192,202$

Ben Chicao: 64

Benabarre: 57, 58n., 193

Benabarre (partido judicial): 142, 207

Benasque: 108

Benedicto Villanueva, Santos: 122n.

Benicalap: 191

Benifons: 115

Benjamin, Walter: VII, XI, 67n.

Béraud, Henri: 64

Bernanos, Georges: 64 y n.

Berruezo, José: 77, 78

Berta: véase Plaza Soriano, Castor

Bertaux, Pierre: 89n., 92

Bes Clavero, Manuel: 122n.

Bielsa: 109

Bierge: 151,159

Biescas: 50n.

Binéfar: 115, 144, 192

Biniés: 230

Biscarrués: 50n.

Blanco, Ángeles: 84

Blasco, Inmaculada: 234n.

Blázquez, Juan: 81

Blecua: 162, 192

Bloch, Marc: 36n.

Boj, Joaquín: 218 
Boltaña: 57, 58n.

Boltaña (partido judicial): 207

Borao Pérez, Lorenzo: 118

Borau, Hilario: 78

Borau: 115

Bordas, Las: 94

Borrás, José (Cinctorrá): 78n., 119, 124

Borraz, Francisca: 53

Borraz, Julián: 174, 212

Bort-les-Orgues (pantano): 77

Bosque Soriano, Joaquín: 122n.

Bram: 63

Brigada B: 109, 110

Brigada 471: 94

Brigada Político-Social: 5, 139

Brigada Vasca: 85

Brigada 21: 109, 111, 118, 140

Brigada X: 109 y n., 141

Brigadas Internacionales: 26, 38, 63, 64n., 71, 82, 83

Brossat, Alain: 37n., 90n.

Broszat, Martin: 42

Broto: 194

Broué, Pierre: 39 y n.

Buchenwald: VIII, XI

Buenacasa, Manuel: 77

Buil, Josefina: 144, 145 y n., 150, 239, 242

Buñol: 129, 178

Buñuel Mir, Joaquín: 167n.

Burguete, Félix: 79

Buró Político del PCE: 157, 186

Bussy Genevois, Danièle: X

Buzet: 76

Caballs (sierras): 117

Cabrito: véase Chillida, Juan Manuel

Caellas Aymerich, Jesús (Carlos y Catalán): 128, 129, 133, 138 y n., 156 y n., 178, 182, 184, 191

Calanda: 53, 54 y n., 55, 56, 206, 235

Calasanz: 58

Caldes de Montbuy: 133
Calomarde: 164

Calvetti (coronel): 92

Calvo, Cristóbal Miguel: 167

Callejas, Gonzalo: 149n.

Camarena de la Sierra: 121, 123, 129

Camarracho (monte): 174

Campanil: 115

Campesino (Valentín González): 94

Campirme (lago): 94

Campón Rodríguez, Pedro: 55

Camporrells: 160

Campos Luque, Concepción: 12n.

Canfranc (valle): 110

Canfranc: 78,79

Cantal (departamento): 77

Cantavieja: 183

Cañada de Benatanduz: 134, 176

Cañada, J.B.: 204n.

Cañete, Antonio: 158 y n.

Cañete: 130

Caparrates: 137

Capella: 152

Carijo: véase Góriz, Manuel

Carlos: véase Caellas Aymerich, Jesús

Carmen (masías): 177

Carrasco, Rufino: 195

Carriedo, Consuelo: 93

Carrillo, Santiago: 93, 94, 102, 129, 184,186

Casabona Terzón, María: 122n.

Casali, Luciano: $27 \mathrm{n}$.

Casanova, Julián: 7n., 21 y n., 22n., 27 y n., 46n., 50n., 54n., 113n., 197n., $217 n ., 225$ y n., $235 n$.

Casanovas, Santiago: 143

Casas, Carmen: 84

Caspe: 51, 108, 116, 195, 235

Casson, Jean: 64 y n.

Castaneda: 115

Castejón de Sobrarbe: 140, 193, 194

Castel Bernuz, Fernando (Rabós): 108, $125 n ., 138$

Castelflorite: 57 
Castellón de la Plana: 131

Castellón de la Plana (provincia): 125n., 129, 130 136, 203

Castellote: 187, 203, 206, 242

Castells, Luis: $12 \mathrm{n}$.

Castigaleu: 141, 152

Castilla: 58

Castro, Manuel: 147

Catalá, Neus: 83n.

Catalán: véase Caellas Aymerich, Jesús

Cataluña: 5, 45, 47, 54, 87, 97, 110, $117,150,172,188,246$

XIV Cuerpo de Ejército de Guerrilleros Españoles: 76, 178

XIV Ejército de Guerrilleros Españoles: 80

Caudé: 128, 129

Cavero de la Cruz, José (Ramírez): 187

CDL: véase Comités départamentales de Libération

CEDA: 72

Cedrillas: 124

Ceferino: véase Durbán, Domingo

Cenarro, Ángela: 3n., 7n., 17n., 29n., 54 y n., 56, 57n., 61, 197n., 217n., $230 \mathrm{n}$.

Cerler: 115

Cerollera, La: 122, 221

Cerro Moreno: 186, 187

César (general): 92

CFLN: véase Comité français de libération nationale

Chaval: véase Nadal Sorrosal, Manuel

Chaval: véase Pardillo, Aniceto

Checoslovaquia: 26

Cherburgo: 98

Chevance-Bertin (general): 88

Chillida, Juan Manuel (Cabrito): 187

Chiva: 130

Churchill, Winston: 99

Cifuentes, Julita: 7n., 51, 52n.

Cinca: 152

Cinca: $17 \mathrm{n}$.

Cinco Villas: 17n., 51, 107, 115, 216
Cinctorrá: véase Borrás, José

Cinctorres: 119, 124

Ciprés, Carmen: 239

Ciudad Real: 213, 237

Clausewitz, Karl von: 249

Close, David H.: 41n.

CNR: véase Conseil national de la Résistance

CNT: véase Confederación Nacional del Trabajo de España

CNT-FAI: 194

Cobo Romero, Francisco: 16, 17 y n.

Cointet-Labrousse, Michèle: $37 \mathrm{n}$.

Colomer, Saturnino: 124

Columna de Hierro: 166

Columna Durruti: 55, 71

Colladico, El: 212 y n.

Collado Ruiz, Segundo: 122n.

Collectif Equipo Juvenil Confederal: 52n.

Collioure (castillo): 64

Comandancia de la Guardia Civil de Graus: 207

Comandancia de la Guardia Civil de Teruel: 176

comandante Jorge: 166

comandante Villacampa: véase Arasanz, Joaquin

Combat (movimiento de la Resistencia): 36

Combat: 86, 97n., 99

Comité Central del PCE: 72, 84

Comité d'Histoire de la Deuxième Guerre Mondiale: 30, 90n.

Comité de la UNE de los Altos Pirineos: 87

Comité de Liberación Nacional español: 86

Comité français de libération nationale (CFLN): 80, 86, 89, 90, 98

Comité Local del PCE de Barbastro: $144,151,157-159$

Comité Local del PCE de Monzón: 157, 158 
Comité Nacional de la CNT: 77

Comité Nacional de la UGT: 81

Comité Provincial del PCE de Huesca: 144

Comité Provincial del PCE de Teruel: 132

Comité Provincial del PCE de Valencia: 129-131

Comité Provincial del PCE de Zaragoza: 145

Comité Regional de Aragón del PCE: 121

Comité Regional de la Federación Local del ML en Barcelona: 117

Comité Regional de Resistencia en Levante: 186

Comités départamentales de Libération (CDL): 89, 90

Compañías de Trabajadores Extranjeros (CTE): 66, 67, 68, 72

Compiègne: 68

Cona: véase Mir, José

Conejero: 122

Conesa, Antonio: 176

Confederación General de Trabajadores Unidos (CGTU): 130, 131

Confederación Nacional del Trabajo de España (CNT): 46, 47, 50 у n., 52n., 75, 77, 87, 113, 116, 117, $126,128,129,132,133,137,138$, 144, 145, 155, 156, 163, 175n., 176, 178, 184, 191, 215n., 219

Conseil national de la Résistance (CNR): $80,86,89,97,102$

Consejo de Aragón: 46, 52, 75

Consejo de Resistencia de la Estación de Rubielos: 239

Consejo Nacional de Liberación de España: 159

Consejo Nacional Libertario: 77

Constante, Mariano: VIII, 68n.

Corbin, J.R.: 10n., 22n.

Cordero, Inmaculada: $237 \mathrm{n}$.
Córdoba: 16, 158

Coronas, Francisco: 231n.

coronel Fabien: véase Georges, Pierre

Corredor Serrano, Francisco (Pepito el Gafas): 131, 132, 156, 167, 178

Cortés, Agustín: 79, 109, 110

Cortés, hermanos: 112

Cortés, José: 109, 110, 120

Cos, Jesús de: 9, 93

Coscojuela de Sobrarbe: 193, 194

Cosculluela, Manuel: 140, 152, 192194, 231

Cossías, Tomás: 5, 6n., 139 y n.

Coudert, Marie-Louise: 13n.

Cruz Navarro, Gabriel (Madriles): 120, 149n.

Cruz, Rafael: 238n.

CTE: véase Compañias de Trabajadores Extranjeros

46 División: 94

43. ${ }^{a}$ División: 78, 109, 140, 150, 153

4. ${ }^{\circ}$ Batallón de Seguridad: 140

Cuba: 204

Cubero Royo, Asunción: 219, 239, 240n.

Cuellos de Lenito: 115

Cuenca (provincia): 129, 130 ,136, 241

Cuerpo de Ejército de Aragón: 110

Cuervo, El: 176, 204, 212, 219, 221

Darnand, J.: 33

Daudet: 64

Dauphin, Cécile: 53n.

Déat, Marcel: 36

Défense de la France: 86, 97n., 99

Degollados (barranco): 176

Delegación de Abastecimientos y Transportes: 59,60

Delegación Nacional de Provincias (DNP): 9

Delicado: 118, 119, 127, 128, 133, 137, $139,152,155,156$

Delpla, Claude: 74 y n. 
Delteil, M.: 72

Denuy: 115

Deseado: véase Mamilo Muñoz, Luciano

Díaz Carmona, Antonio: 205n.

Dirección General de la Guardia Civil: 9, 10n., 120

Dirección General de Seguridad: 121n., 138,200

Dirección Nacional de Provincias: 201

División 151: 110

División 152: 110

División 51: 110

División 52: 110

División Azul: 88

División Leclerc: 81

Djelfa: 64

Dordoña: 94

Dos Torres de Mercader: 134, 183, 210

204 División de Guerrilleros: 91, 93, 111, 104, 153

234 Brigada de Guerrilleros: 72

Dreyfus-Armand, Geneviève: 66, 67n., 69 y n., 71n., 76n., 82n., 83 y n., $89 \mathrm{n}$.

Drole: véase González, Valeriano

Dufour, Jean-Louis: 88n., 97n., 99n.

Durbán, Domingo (Ceferino y Viriato): 219, 220

Durruti, Buenaventura: 55, 195n.

EAM (Frente Nacional de Liberación): 40

Ebro: 32, 116, 140, 195

Echo: 50n., 108, 109, 112, 113 y n., $140,141,230$

Echo (valle): 79, 120, 149, 157

EDES (Unión Nacional Griega Democrática): 40

Ejea de los Caballeros: 51, 107

Ejército Rojo: 178

Ejulve: 211

EKKA (Movimiento de Liberación Nacional y Social): 40
ELAS (Ejército Nacional de Liberación): 40

Emiliano Ruiz, Constantino (Eulogio): 187

Enrique: véase Hernández Ruiz, Eduardo Épila: 148

Eripol: 143

Eriste: 152

Erla: 148

Escalé: 115

Escandón (puerto): 164

Escarrilla: 230

Escuela de Formación Politicomilitar Cara a España de montaña Negra: 74

Esgleas, Germinal: 87

España: VIII, IX, XI, 3-6, 8 y n., 11n., 15, 16, 21, 22n., 26, 29, 30 y n., 32, 35, 38, 39, 42, 43, 67 y n., 68-76, 77n., 78, 80, 82-85, 88, 91, 92, 94, 96, 97, 99-102, 104, 105, 107-109, $111,114,118-120,126,127,134$, 136, 137, 140, 142, 143, 147, 153, 160, 172n., 190, 194, 197n., 199n., 204, 205, 224, 226, 236, 243, 246, $247,249,250$

Espés: 115

Esquinazau: véase Beltrán, Antonio

Estado Mayor de la AGLA: 156, 178, 183

Estado Mayor de la Agrupación de Guerrilleros Reconquista de España: 108, 109, 131

Estado Mayor de la IX División: 132

Estado Mayor de los Guerrilleros Españoles: 80, 99, 109

Estado Mayor del Cuerpo de Ejército de Aragón: 110

Estados Unidos: 98

Esteban Mínguez, Agapito (Mateo): 183, 156

Esterri d'Aneu: 94

Estopiñán: 115 
Estrasburgo: 99

Eulogio: véase Emiliano Ruiz, Constantino Europa: IX, 4, 8, 11n., 13, 14, 26, 30 y n., 33, 38-40, 63, 64, 123, 247

Extremadura: 141, 236

Facerías, José Luis: 194, 195

FAI: 47, 124, 131

Falange (FET-JONS): 9, 29, 54, 56, 57, 60 y n., 61, 84, 88, 103, 104, 123, $134,162,183,201,206,207,212$ y n., 223

Falcón, Irene: 237

Fandos Izquierdo, José: 183

Fantova: 115

Farge, Arlette: 53n.

Febo, Giuliano di: 237

Federación de Guerrillas de León-Galicia: 118,237

Federación Española de Trabajadores de la Enseñanza (FETE): 132

Federación Local del ML en Barcelona: 117

Federación Nacional de Trabajadores de la Tierra (FNTT): 50n., 217

Federación Sindical Mundial: 237

Félez Marqués: 122n.

Fernández Clemente, Eloy: 6 y n.

Fernández Pancorbo, Paloma: 6 y n., 116n., 120 y n., $121 \mathrm{n}$.

Fernández, A.E.: 6n.

Fernández, Ángel: 195 y n.

Fernández, Aurelio: 195n.

Fernández, Luis (general Luis): 73n., 78, 81, 82, 92, 93 y n., 127

Ferrer: 144

FETE: véase Federación Española de Trabajadores de la Enseñanza

FET-JONS: véase Falange

FFI: véase Forces françaises de l'intérieur

Fink, Carole: 36n.

Fiscalía de Tasas y Abastos: 137, 153, $159,225-227,248$
Fittko, Hans: 67n.

Fittko, Lisa: 67n.

FNTT: véase Federación Nacional de Trabajadores de la Tierra

Folguera, Pilar: 11n., 12n.

Font, Christian: 34n.

Fontana, Josep: 29 y n.

Forcadell Álvarez, Carlos: XI

Forcall: $125 n$.

Forces françaises de l'intérieur (FFI): 80, 83, 88-91, 94, 96-99, 103, 104, 108, $118,128,129$

Fortanete: 49, 123

Foz-Calanda: 174, 212 y n.

Fraga: 116

Fraga (partido judicial): 207, 224

Frago, El: 111

France d'Abord: 81

France Libre: 81

Francia: VIII, X, 8 y n., 9, 13n., 17, 23, $26,30,32-35,37-40,55,63,64,67$ y n., 69 y n., 71-77, 78n., 80, 82 y n., 83-85, 87-89, 92, 95-104, 107$112,119,120,122,127-129,131$, 132, 135-137, 139-143, 146-151, 153-155, 157, 158, 160, 163, 167, 176, 178, 182-191, 193-196, 241, 243, 247, 249

Francisco: véase Serrano Iranzo, Francisco Franco, Francisco: XI, 7n., 27, 30n., 65, $67,70,72,87,88,94,96,98-100$, 103-105, 134, 136, 147, 168, 195, 198,200

Francos, Ania: 13n.

Franc-Tireur (movimiento de la Resistencia): 36 y $\mathrm{n}$.

Franc-Tireur: 86, 97n., 99

Francs-Tireurs et partisans: 34

Fraser, Ronald: 12 y n.

Frasquito: véase Guillén Montoliu, Florencio

Frente Popular: 64, 174, 175n.

Froilán de Blanco, Santiago: 122n.

FTP-MOI: 63, 71, 76, 80 
FUE: 131

Fuentes Arilla, Alejandro (Lobera): 120

Fuertes Vidosa, Ángel (Antonio y Alfredo): 108, 118, 119-121, 123, $127-$ 129, 131, 133, 135, 137, 138, 141, 149, 151 y n., 152-155, 156 y n., $165,167,177,178,185,202,220$

Fueva, La: 139, 162

Fueva, La (valle): 109, 111, 118, 140, $141,143,152,160,161,193,227$

Gabinete Militar de la Prefectura: 101

Gago, José M.a: 232n.

Gaillac: 81

Galán, Fermín: 109, 126

Galarza, Vicente (Andrés): 129, 130, $148,152,178,202$

Galicia: 4, 107, 150, 236

Galindo, Pedro: 109n.

Galindo Asensio, Francisca: 53

Gálvez, Manuel (Sevilla y Aguanta): $149 \mathrm{n}$.

Gallisué: 114

García Delgado, José Luis: 17n.

García Monforte, Manuel: 134

García Murciano, Emilio: 174, 175n.

García Oliver, Juan: 195n.

García Pradas, J.: 8n.

García Vivancos, Miquel: 195n.

García, Cristino: 110, 142, 147

García, Florián (Grande): 129, 130, 131 y n., 132, 184, 186, 187, 190

Garrobera: véase Rovira, Bernabé

Gascón, Antonio: 76n.

Gaulle, Charles de: VIII, 62, 80, 87-89, 98, 99, 151n

general Luis: véase Fernández, Luis

Georges, Pierre (coronel Fabien): 32, 33

Gérard, Claude: 83

Gerbe: 230

Germán, Luis: 225n.

Gestapo: XI

Gil, Ángela: 171 y n.
Gil: véase Medina

Giménez, Roser: 93

Giménez, Wenceslao (Rodolfo): 195

Giménez Corbatón, José: 119n., 170n., 173n., 176n., 211n.

Giménez Orive, Wenceslao: 194, 195

Gimeno, hermanos: 112

Gimeno, Luis: 79n., 112 y n., 113n.

Gimeno, Manuel: 92

Ginebrosa, La: 178, 218 y n.

Giner, Salvador: 205n.

Giral, José: 135, 136, 226

Giraud, Henri: 80

Girón, Manuel: $24 \mathrm{n}$.

Gobernación (Ministerio): 121

Gobierno Civil de Castellón: 9

Gobierno Civil de Huesca: 9, 207, 208 y n., 228, 229

Gobierno Civil de Teruel: 9, 121 y n., 169, 240n.

Gobierno Civil de Zaragoza: 9

Gobierno Militar: 207

Gobierno Vasco: VIII

Gómez Porra, Rafael: 6n.

Gómez, Silvestre: 76, 81

González Calleja, Eduardo: 197, 198n.

González Castillejo, M. José: 12n.

González, Valentín: véase Campesino

González, Valeriano (Drole): 141 y n., 152, 192

Góriz, Manuel (Carijo): 170n.

Gracia Fleringan, Simón: 195

Gracia Jarque, Manuel (Lorenzo): 183

Grado, El: 193, 194

Grafias, Mamés: 92

Granada (provincia): 163, 213

Grande: véase García, Florián

Graus: 46n., 143, 193, 208n., 227, 229

Grecia: 38-41, 247

Gros, José: 6n., 188, 189 y n.

Groups de Travailleurs Étrangers (GTE): $68,69,72,77,79$

Grupo de Guerrilleros I de Aragón: 119 
Grupo de Guerrilleros II de Aragón: 126 grupo Rosa: 115

GTE: véase Groups de Travailleurs Etrangers Guadalajara (provincia): 129

Guara (sierra): 111, 115, 118

Guardia: 193

Guardia Civil: 5, 9, 110, 112, 115, 118, 122, 125n., 127, 128, 136, 137, $148,152,162,165-167,170,171$, 173-175, 177, 178, 181, 182 y n., 183, 186, 188, 190-193, 195, 196, 203, 204 y n., 206, 207, 210, 211, $213,220,221,228,230,238,241$ 243, 248

Guardia de Franco: 174, 233

Guaso: 143

Gúdar: 170, 171, 173, 191, 209, 219, 249

Gúdar (sierra): 203, 218

Güell: 115

Guérisse, Albert (Pat O'Leary): 76

Guidez, Guylaine: 83n.

Guillén Montoliu, Florencio (Frasquito): 119, 170, 219

Guillén, Florencio (Viejo): 160 y n., 170, 171, 189, 191, 209, 219, 238n., 249

Guillon, Jean-Marie: 24n., 31 y n., 82n.

Guimerá (masía): 156, 177

Gurs: 63, 64, 67n.

Gusen: 68

Halbwachs, Maurice: XI

Harding, Susan: 18n., 22n., 46 y n., $50 \mathrm{n}$.

Heine, Hartmut: 87n., 215 y n.

Hendaya: 105

Hérault (departamento): 88, 90n.

Hermandad Sindical Local de Ganaderos de Echo: 230

Hermandades de Labradores y Ganaderos: 59, 159, 230n.

Hernández Ruiz, Eduardo (Enrique y tío Pito): 182

Herrero, David: 164
Higueruelas: 241

Híjar: 227

Hitler, Adolf: 105

Hobsbawm, Eric J.: 24 y n.

Hondo (barranco): 172n.

Hood, Robin: 24

Hospital de Benasque. 108, 115

Huerta de Vero: 143

Huerto: 162

Huesca: 50n., 57, 113, 145, 152, 195

Huesca (partido judicial): 217, 224

Huesca (provincia): 50, 51, 58 y n., 100, $101,107,115,120,121,125,126$, 139, $140,142,145,146$ y n. 149 , 150, 152, 156, 159, 192, 194, 196, 206, 207, 210, 212, 216-218, 224, 227, 232, 249

Humanité, L': 86

Iatrides, John O.: 41n.

Ibáñez Alconchel, Doroteo: 119-121, $123,125-130,132,133,136,137$, 139, 149, 152, 154 y n., 172, 183, 188,241 y n.

Ibáñez, José: 195

Ibárruri, Dolores: 6n., 102, 237, 238

Ibieca: $22 \mathrm{n}$.

Información e Investigación de Teruel: 57

Inglaterra: VIII, 17, 40, 98

Institut für Zeitgeschichte: 42

Intelligence Service: 40

Irance, Isidro: 134

Isaba: 115

Italia: 26, 29, 30, 32, 38-40, 63, 123, 247

Izquierda Republicana: 46, 79, $175 n$.

Jaca: 9, 50n. 101, 109, 110, 163, 230

Jaca (partido judicial): 217 y n.

Jaén: 213

Japón: 32

Jarque Aspa, Tomás: 175n. 
Jarque Martínez, Bienvenido: 175n.

Javalambre (sierra): 121, 203, 218

Javaloyas: $175 n$.

Jefatura Provincial de Huesca: 229

JEL: véase Junta Española de Liberación

Jiménez, Isaías (Manolo y Maqui): 182n., 187

Jimeno, Arsenio: 66n., 81 y n.

JSUN: véase Junta Suprema de Unión Nacional

Judt, Tony: 30, 39n.

Juliá, Santos: 93, 197n.

Junta Española de Liberación (JEL): 73

Junta Suprema de Unión Nacional (JSUN): 86, 147

Juventudes Comunistas: 130

Juventudes Libertarias: 128, 156, 184, $215 n$.

Kaiser, Carlos J.: 6n.

Kaplan, Temma: 240 y n.

Kédros, André: 24n., 41n.

Kedward, H.R.: 10, 17, 23, 24n., 34n., $38 n$.

Kelsey, Graham: 46n.

Kent, Victoria: 86, 102

KKE (Partido Comunista Griego): 40

Komintern: 39, 42, 74

Krebs, Gilbert: $42 n$.

Kriegsmarine: 32

Laborie, Pierre: 31n., 82n.

Lacuei, Félix (Sos): 120, 148, 149

Ladruñán: 136

Laguía (teniente general): 101

Lagunas, Las: 115

Landas (departamento): 90n.

Lanuza: 230

Laperdiguera: 57

Largo Caballero, Francisco: 70

Larroguebrou (departamento): 77

Lascuarre: 141

Lascuarre (sierra): 141, 152
Laspuña: 96

Lassère (comandante): 88

Lastanosa: 193

Laval, Pierre: 34, 70

Leclerc, Françoise: 37n., 90n.

Ledesma, José Luis: $51 \mathrm{n}$.

Legión Extranjera: 66

Leguineche, Manuel: 121n.

Lemús, Encarnación: 237n.

León (provincia): 4, 107, 213, 236

Lérida: 128

Lérida (provincia): 101, 119, 157

Levante: 45, 76, 107, 108, 111, 127, 129, 130, 137, 139, 146n, 150, 152, 163, 166, 196, 217, 219, 226

Levi, Primo: VIII

Libération (movimiento de la Resistencia): 36

Libération: 36

Libros: 166, 167, 242

Liga de Familias Numerosas: 68

Limia Pérez, Eulogio: 213

Linares de Mora: 204

Linz, Juan José: 27 y n.

Liria: 130

Lisner: 63

Líster, Enrique: 52, 102, 126

Litera, la: 51, 151, 152

Loarre: $50 \mathrm{n}$.

Lobera: véase Fuentes Arilla, Alejandro

Loira (departamento): 68

Loira Atlántico (departamento): 90n.

Loiret (departamento): 90n.

London, Arthur: IX, 71

London, Lise: IX, 71

Londres: 62

López Rodríguez, Manuel: 177

López Tovar, Vicente: 91, 92, 93 y n., 94, 95n., 153

López, Miguel: 74

Lorenzo: véase Gracia Jarque, Manuel

Lot y Garona (departamento): 90n.

Lottman, Herbert: 37n., 90n. 
Luchon: 84

Luebbert, Gregory M.: 28 y n.

Luesia: 120

Luna (sierra): 120, 157

Luna: 116, 148, 149

Lyon: 36

Madeleine: 109

Madrid: 5, 9, 103, 110, 111, 123, 129, 131, 149

Madriles: véase Cruz Navarro, Gabriel

Maella, Jesús: 148

Maestrazgo: X, 12, 20, 116, 118, 122, 124, 154, 155, 196, 203, 204, 210, $213,218,241,242$

Maestrazgo (sierra): 203, 216

Main-d'oeuvre immigrée (MOI): 63, 7983

Majou: 72

Malefakis, Edward: 28n.

Malraux, André: 64 y n.

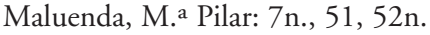

Mamilo Muñoz, Luciano (Deseado): 119, 136, 177

Manolo: véase Jiménez, Isaías

Manouchian: 82

Mans, Le: 98

Manso: véase Amorrortu, Germán

Manuela (masico): 177

Manzanera: 132

Maños, los: 194, 195

MAOC: véase Milicias Antifascistas de Obreros y Campesinos

Maqui: véase Jiménez, Isaías

Marcot, François: 35 y n., 74n.

Marèges (pantano): 77

Mariano: véase Monzón Reparaz, Jesús

Marqués, Piedad: 242

Marrand-Fouquet, Catherine: 238n.

Marsella: 188

Martí, Mariano: 148

Martín, Eutimio: 95

Martín del Río: 174
Martín Santos, Luis: 3n.

Martínez, Amador: 65n., 96 y n., 108, 141 y n., 149, 157 y n., 158, 160

Martínez, hermanas: 238n., 241

Martínez Barrio, Diego: 73

Martínez de Baños Carrillo, Fernando: 96n., 115n.

Martínez Hernández, Caridad: 55

Marzal, Luis: 213

Mas de las Matas: 46 y n., 107, 125n., $138,178,213$

Mas de Mataví (masía): 221

Mases, los: 239

Mateo: véase Esteban Mínguez, Agapito

Mauriac, François: 64

Mauthausen: IX, 68, 158

Mediano: 193, 194

Medina (Tito y Gil): 156, 177

Mediodía-Pirineos (región): $64 n$.

Méjico: 70, 73, 102

Membrado Giner, José: 122n.

Mequinenza: 51

Meridja: 64

Merli: 142

Metaxás, Ioannes: 40

Michel, Henri: 30, 31, 32n.

Milián, Jesús: 60, 61n., 228

Milicia de Santiago: 228

Milicias Antifascistas de Obreros y Campesinos (MAOC): 131

Mina, la: 115

Mir, José (Cona): 133, 167, 209, 220, 222, 239

Mirambel: 124

MLE: véase Movimiento Libertario Español

MOI: véase Main-d'oeuvre immigrée

Molinero, Carme: 234 y n.

Molino, Juan Manuel: 77

Molinos, Los: 161

Molotov (Viacheslav Mijailovich Skriabin): 71

Mombiel, Modesto: 122n. 
Monasterio (general): 93

Monegros: 152

Monesma: 161

Monfort: 193

Monforte, Antonio: 166

Monreal del Campo: 130

Montalbán: 130

Montañesa (peña): 151, 161, 195, 196

Montauban: 71, 72

Monte Roda: 152

Montero, Remedios: 238n., 241

Montero, Victoriano: 48

Montoliu, Felisa: 170, 209, 238n.

Montorio González, José: 120

Montoro de Mezquita: 173, 183, 211

Montpellier: 77

Montréjeau: 88

Montseny: 117

Montseny, Federica: 87

Monzón: 110, 125, 140, 142-144, 149, 159, 160, 161n., 162n., 235, 242

Monzón Reparaz, Jesús (Mariano): 72, 73 y n., 91, 96, 99, 102

Mora de Rubielos: 130, 170

Morán, Gregorio: 73n., 97n.

Morand: 64

Morcillo Jarabo, Francisco: 116

Morella: 119,124, 130, 135, 182, 213

Moreno, José: 140, 144

Moreno Gómez, Francisco: IX, 16, 17n., 93n., 197n., 204 y n.

Moreno Torres, José: 176

Moreno, Roque: 198n.

Morillo de Monclús: 111

Moscardó, José: 92, 93

Moscú: 70, 72, 99, 102, 137, 179, 186

Mosqueruela: 47, 48, 119, 122n., 124, 125n., 133, 137, 164, 166, 171, 177 y n., 183, 191, 218, 219, 222n.

Motilla del Palancar: 130

Moulin, Jean: 80

Mouvements unifiés de la Résistance (MUR): 36, 97
Movimiento Libertario aragonés: 194

Movimiento Libertario Español (MLE): 78n., 81, 82, 87, 101, 116, 117, $194,215 n$.

Muela, La: 195

Mujeres Libres: 235

MUR: véase Mouvements unifiés de la Résistance

Murciano Pradas, Florentino: 175n.

Mussolini, Benito: 105

Nadal Sorrosal, Manuel (Chaval): 120

Nanclares de Oca: 227

Narciso: 152

Naredo, José Manuel: 21n.

Nash, Mary: 240n.

Naval: 194

Navarra: 20, 100, 140, 150

Navarro, Mariano (Tuerto de Fuencalderas): $120,148,149$

Negrín, Juan: 103

Nelson: 129

Nerín: 115, 134

Nicolás, Encarna: 29 y n., 57n., 59 y n.

Niel, Sonia: 93

Noguero: 195

Nogueruelas: 135, 166

Nonan-les-Pins: 98

Nosotros: 195 n.

O'Leary, Pat: véase Guérisse, Albert

Ochagavía: 116

Oise (departamento): 90n.

Olba: 174

Oliete: 47

Olorón: 101

Oncins: 161

ONU: 110,147

Orador-sur-Glane: 35

Orense (provincia): 232n.

Organisation spéciale (OS): 32, 33, 62, 63

Orihuela del Tremedal: 204

Oronal: véase Prades Pitarch, Victoriano 
Ortín Ayora, Daniel (Serrano): 119 y n. Ortiz, Antonio: 195n.

Ortiz, Jean: 79n.

Ortiz, Plácido: 195

OS: véase Organisation spéciale

Ossau (valle): 79

País Vasco: 20, 172

Paisano: 119

Palencia: $122 n$.

Palomar de Arroyos: 165

Pallarés, Felipa: 124

Pallaruelo: 111, 242, 243

Pamplona, Manuel: 100

Panillo: 193

Pardillo, Aniceto (Chaval): 195

Pardina, La: 193, 231

París: X, 8n., 32, 37, 63, 71, 73, 80, 82, $85,89,103,158,243$

Paris Eguilaz, Higinio: 60 y n.

Parras de Castellote, Las: 165, 166n., 167

Partido Comunista de España (PCE): 4, 5 , 6 y n., 15n., 50n., 52n., 70-72, 73 y n., 74, 78, 79, 84, 86, 87, 91-93, 95, 96, 99, 102-104, 108, 115-121, 123$126,128,130-132,135,139,140$, $142,144,145-154,156-158,160$, $161,163,173,178,179,185-187$, 190-193, 200, 215n., 220, 236, 239, 243, 244 y n., 246-249

Partido Comunista Francés (PCF): VIII, $32,34,38,39,62,63,70,74,76$, 77, 86, 97, 110

Partido Obrero de Unificación Marxista (POUM): 71, 131, 132

Partido Socialista Obrero Español (PSOE): 70, 101

Parzán (puerto): 195

Passerini, Luisa: 12

Pastora: véase Pla Meseguer, Teresa

Pau: 115

Payne, Stanley G.: 27n.
Paz, José Antonio: 81

PCF: véase Partido Comunista Francés

Pedro, Carmen de: 72, 84, 92

Pedro: véase Bas Aguado, Francisco

península ibérica: 150

Pepito de Mosqueruela: véase Vicente Zafón, José

Pepito el Gafas: véase Corredor Serrano, Francisco

Peralta: 162

Pereira, Francisco Javier: $11 \mathrm{n}$.

Pérez, Gabriel: 109

Pérez Cubero, Manuel (Rubio): 183, 188, 191, 219, 239, 240

Pérez Escorihuelas, Antonio: 176

Pérez Galarza, Pelegrín (Ricardo): 76 y n., 178 y n., 179, 180 y n., 181, 183, 186, 202

Pérez Salvat, Adelino (Teo): 188

Pertusa: 162

Pétain, Philippe: 33, 68, 70

Petrol: véase Ramiá Ciprés, José

Picasso, Pablo Ruiz: 86

Pike, David Wingeate: 82 y n., 92 y n., 93, 97 y n., 98 y n.

Pina de Ebro: 55

Pina de Ebro (partido judicial): 224

Pineta (valle): 109, 111

Pinocho: véase Álvarez Canosa, Emilio

Piñana, Aurora: 209, 239

Piquer Vicente, Elías: 108

Pirineo aragonés: 109, 112

Pirineo navarro: 100

Pirineos: 67n., 75, 84, 93, 102, 110, $115,152,196,212$

Pirineos Atlánticos (departamento): 63

Pirineos Orientales (departamento): 98, 163

Pitarque: 119 y n., 124, 137, 204, 211

Pizarro Cenjor, Manuel: 169, 173, 174, 180, 212, 213, 232

Pla Meseguer, Teresa (Pastora): 190 y n., 192,241 y n. 
Planas, Jerónimo: 212

Plans de Castellote: 122n.

Plastiras, N.: 40

Plaza Soriano, Castor (Berta): 177

Pleno Nacional de Regionales: 194

Pobo, El: 212 y n.

Polonia: 26

Pomar: 193

Ponferrada: 24n.

Pons Prades, Eduardo: 6n.

Ponzán, Francisco (François Vidal): 71, 75,76 y $\mathrm{n}$

Ponzán, Pilar: 66n., 76 y n.

Port-Bou: VII, 140

Portacoeli: 131, 132

POUM: véase Partido Obrero de Unificación Marxista

Prada Rodríguez, Julio: 237n.

Prades: 117

Prades Pitarch, Victorino (Oronal): 124

Prepirineo oscense: 20

Preston, Paul: 27 y n., 54n., 198 y n.

Prieto, Indalecio: 47, 70, 73, 182

Pro Ruiz, Juan: 18 y n.

Prost, Antoine: $83 n$.

Provenza: 24

PSOE: véase Partido Socialista Obrero Español

Puebla de Benifasar: 181, 203

Puente de Montañana: 152

Puente la Reina: 50n.

Puente Pérez, Baltasar (Sargento): 120

Puerto García, Balbina: 134

Pueyo de Jaca, El: 229

Puicheri: 140

Querol, José María (Sedasé): 124

Quílez Quílez, León: 119, 121, 124

Rabós: véase Castel Bernuz, Fernando

Ramiá Ciprés, José (Petrol): 108, 119, 125n., 138, 139, 155, 239

Ramírez: véase Cavero de la Cruz, José
Ramón: 177

Ramón: véase Ruiz Cuadrado, José

Ramos, Joaquín: 82



Raval: 152

Reconquista de España (operación): 85, 91, 92, 109, 115, 116, 118, 140, 153

Reconquista de España: 73, 75, 79, 84, 86, 91, 98, 101, 104, 105

Regajo (cuevas): 121

Regiones Devastadas: 176

Remacha, Ramón: 116

Renclusa, La: 115

Requena: 130

Resistencia francesa: 8, 11n., 13n., 23, $24,26,30-35,36$ y n., 37, 38, 62, 64n., 69, 72, 74-77, 78n., 80-82, 83 y n., 86, 89-91, 94, 97, 101, 102, $104,110,127,128,132,140$, 146n., 149, 156, 162, 249

Ribagorza: 51, 151, 152, 157

Ribbentrop, Joachim von: 71

Ricardo: véase Pérez Galarza, Pelegrín

Ricol, Lisa: véase London, Lise

Richards, Michael: 3n., 7n., 23 y n., 54n., 59n.

Rieucros: 63, 64

Riglos (peña): 50n.

Rincón de Ademuz: 186

Ríos, Jesús: 72, 76

Ripa, Yannick: 53n., 238n.

Rivesaltes: 63, 72

Roda de Isábena: 141

Rodeno (monte): 174, 175n.

Rodolfo: véase Giménez, Wenceslao

Rol-Tanguy, Henri: 83 y n.

Romeu, Fernanda: 6 y n., 10n. 13n., 130n., 186n., 237n.

Roncal (valle): 157

Rosal, Amaro del: 70

Rosel, Antonio: 72, 145

Rosellón (departamento): 63 
Rousso, Henri: 90n.

Rovira, Bernabé (Garrobera): 121 y n., 219

Royo, Mariano: 46n.

Rubielos de Mora: 123, 172n., 219, $240 \mathrm{n}$.

Rubio: véase Pérez Cubero, Manuel

Rubio: véase Serrano Iranzo, Francisco

Rufat, Ramón: 116

Rufos, Ángel: 193

Ruiz Carnicer, Miguel Ángel: 54n.

Ruiz Cuadrado, José (Ramón): 120

Ruiz Torres, Pedro: $12 \mathrm{n}$.

Rújula, Pedro: $54 \mathrm{n}$.

Rumania: 73

Rusia: 53

Sabaté, Quico: 24 y n., 195

Sabiñánigo: 50n.

Sabio, Alberto: 25 y n.

Saint Étienne: 68

Saint Michel: 71

Salanova: 144

Saldón: $175 n$.

Salinas de Hoz: 127, 141, 143, 206, 229

Salinas de Valtablao: 177

Salinillas: 20

Salomón, M. ${ }^{a}$ Pilar: $7 \mathrm{n}$.

Saludas, Joaquín: 143, 144

Salvador Salvador, Víctor: 48

San Agustín: 172n.

San Carlos de la Rápita: 188

San Esteban de Litera: 151

San Juan de la Peña (sierra): 115

San Rafael (altos): 170, 173, 211

Sánchez Biedma: 92

Sánchez Brun, Gaudioso: 61n., 155n.

Sánchez Lázaro, Hilario: 175n.

Sánchez Montoya (capitán): 213

Sánchez Recio, Glicerio: 29n.

Sánchez, Domingo (Vilches): 131, 182

Sánchez, Ferrán: 97n., 108n., 218n.

Sansebastián: 144
Santa Cilia de Jaca: 115

Santa Cruz de la Serós: 50n.

Santa Cruz de Moya: 186

Santa María de Buil: 193-195

Santapau, Valentín: 218n.

Santo Domingo (sierra): 111, 118, 120, 127

Santolea: $125 n$.

Santolea (pantano): 221

Sanz, María: 53n.

Sanz, Miguel Ángel: 81, 92

Sanz, Ricard: $195 \mathrm{n}$.

Sargento: véase Puente Pérez, Baltasar

Sariñena: 193

Sariñena (partido judicial): 207

Sarsa de Surta: 194

Sástago: 51

Scott, James C.: 7n., 23n., 25, 60, 243

Schelin, Gérard: 42n.

Sección Femenina: 234 y n.

Secretaría de Propaganda de la Federación Local de París del MLE-CNT: $8 \mathrm{n}$.

Secretariado de Unión Nacional Española: 104

Section française de l'Internationale ouvrière (SFIO): 110

Sedasé: véase Querol, José María

Segorbe: 130

Segura Ferrer, Antonio: 124

Selgua: 193

Semprún, Jorge: VIII, XI

Senelin, Jacques: $31 \mathrm{n}$.

Seno: 178

Seo de Urgel: 190

Septfonds: 63

Serrano: véase Ortín Ayora, Daniel

Serrano, Secundino: IX, 6n., 236 y n.

Serrano Iranzo, Francisco (Francisco y Rubio): 183, 187, 190 y n., 192, 206, 219

Serrano Iranzo, Miguel: 183, 219

Serrano Serrano, José: 165, 167 
Service du travail obligatoire (STO): 77 , 79

Servicio de Contraespionaje francés: 92

Servicio de Información de la AGLA: 183

Servicio de Información de la Guardia Civil: 187

Servicio de Inspección Especial Periférico (SIEP): 132, 133

Servicio Nacional del Trigo: 58, 60

Sevilla: 108

Sevilla: véase Gálvez, Manuel

Sevilla-Guzmán, Eduardo: 15n., 20n.

Sevillano, Francisco: 198n.

SFIO: véase Section française de l'Internationale ouvrière

Shanin, Theodor: 15n., 19

SIEP: véase Servicio de Inspección Especial Periférico

Sierra, Lorenzo: 143

Sindicatos de Teruel: 60, 228

Siresa: 115

Sobrarbe: 51, 109, 140, 151, 152, 157 , 196

Sociedad Teledinámica Turolense: 168

SOE: véase Special Operations Executive

Solé, Pepita: 66n., 81n.

Solsona: 156

Somatén: 95, 118, 136, 141, 197n., 206, 233

Somontano: 152, 162

Somport: 79

Sorel, Andrés: 6n.

Soriano García, Silvano: 175n.

Soriano Villalba, Manuel: 175n.

Sos: véase Lacuei, Félix

Sos del Rey Católico: 52, 107, 120

Soutelo, Raúl: 232n.

Special Operations Executive (SOE): 40, 75

Stalin (Iosif Vissarionovich Dzugashvili): 39, 99, 134, 158, 179, 186, 248

Sternhell, Zeev: 33n.
STO: véase Service du travail obligatoire Sueves: 152

Tamarite (partido judicial): 207

Tamarite Ventafarinas: 151, 161

Tamborero (partida): 183

Tanque: 141 y n., 160

Tarbes: 87

Tarragona: 190

Tarragona (provincia): 129

Téllez, Antonio: 5n., 76n., 195 y n.

Témime, Émile: 74 y n., 78n., 97n.

Tenèze, Irène: 9, 73n.

Teo: véase Pérez Salvat, Adelino

Tercio: 95, 213

Teruel: 121, 123, 130, 148, 164, 168, 200, 219

Teruel (provincia): 17n., 47, 51, 61, 107, $108,115,118,119,121,123-126$, 129, 130, 136, 137, 139, 140, 145, 146n., 149, 159, 162-167, 169, 173, 191, 203, 206, 210, 212-214, 216219, 221, 224, 225, 228-230, 232, 233, 236n., 249

Thalman, Rita: $33 \mathrm{n}$.

Thébaud, Françoise: 13n., 37n., 90n.

Thompson, Edward: 17

Tiermas: 115

Tierrantona: 111

tío Pito: véase Hernández Ruiz, Eduardo

Todt (organización): 69 y n., 75

Tolva: 193

Torbado, Jesús: 121n.

Toro Muñoz, Francisco Miguel de: 199n.

Torres, Celestino: 82

Torres, Francisco: $231 \mathrm{n}$.

Torres de Alcanadre: 162

Torres del Obispo: 193

Tosán, Manuel: 140, 143n., 144, 145 y n., $160,162,193$

Toulouse: $64 n ., 71,73,76,82,84,87$, 88,89 y n., 90, 92, 101, 102, 127, 137, 148, 151, 194, 195 
Tramacastiel: 204

Tramacastilla: 204, 230

Trapiello, Andrés: 104n.

Tremp: 94

Trempé, Rolande: 88n., 91, 97n., 99 y n.

35. ${ }^{\text {a }}$ Brigada de la MOI (brigada Marcel

Layer): 82

Tronchón: 173

Trujillano, José M.a: 232n.

Tuerto de Fuencalderas: véase Navarro, Mariano

Túnez: 64

Tusell, Javier: $27 \mathrm{n}$.

Ugarte, Javier: 20 y n., 28, 185, 222 y n.

UGT: véase Unión General de Trabajadores

UHP: véase Unión de Hermanos Proletarios

UME: véase Unión de Mujeres Españolas

UNE: véase Unión Nacional Española

Unión de Guerrilleros Españoles: 127

Unión de Hermanos Proletarios (UHP): 86

Unión de Mujeres Españolas (UME): 87, $244 n$.

Unión General de Trabajadores (UGT): 46 y n., 50n., 75, 87, 113, 131, 155, 175 n., 178

Unión Nacional de Intelectuales Españoles: 86,87

Unión Nacional Española (UNE): 64n., 72-78, 80, 81, 82 y n., 84, 86-89, 91, 93, 94, 97 y n., 98, 99, 101-104, $108,127,140$

Unión Soviética (URSS): 38-40, 42, 72, 73, 96, 99, 102, 178, 188

Universales (montes): 122, 153, 167

Urdiceto (puerto): 109, 111

URSS: véase Unión Soviética

Utrillas: 116, 134, 154, 155, 169, 174

Vacheron, Raymond: 39 y n.

Valcarlos: 100

Valdecuenca: 174, 175n.
Valdelinares: 171, 172, $204 n$.

Valdeltormo: 175

Valderrobres: 116, 130, 213

Valencia: 127, 129-132, 137, 138, 148, $149,152,153,178,182,219,239$

Valencia: 174

Valencia (provincia): 49, 129, 135, 139

Valentín: 139

Vallador, José Antonio: 78

Varela, Alfredo: 232n.

Vargas: 129

Vaucluse (departamento): 73

Vázquez, Pilar: 93, 111

Venner, Dominique: 33, 63n.

Venta del Aire: 166

Verdún: 33

Vernet: 63, 64, 71

Viacamp: 193

Vicente, Cesario: 171

Vicente Zafón, Alberto: 133

Vicente Zafón, hermanos: 119, 133

Vicente Zafón, José (Pepito de Mosqueruela): 129, 133, 191, 192, 219

Vichy: VIII, 11n., 33 y n., 34-37, 62, 68, 69, 71, 74, 85, 98

Vicién: 50n.

Victor (coronel): 92

Victoria (esposa de Antonio Rosel): 72

Vidal Sales, J.A.: 6n.

Vidal, François: véase Ponzán, Francisco

Vieja, paso de la: 110

Viejo: véase Guillén, Florencio

Viella: 93

Viella (túnel): 111

Vigos, Carmen: 53

Vilar, padre: 102

Vilches: véase Sánchez, Domingo

Villanueva, Ricardo: 171

Villar del Cobo: 204, 212

Villarluengo: 123, 176

Villastar: 123

Villegas, Jean-Claude: 66

Villel: 123 
Villellas, Narciso: 140, 152, 192, 202

Villorres: $125 n$.

Vinaroz: 188

Violada, La: $17 \mathrm{n}$.

Virgili, Fabrice: $37 \mathrm{n}$.

Viriato: véase Durbán, Domingo

Vistabella: 124

Vistué, Enrique: 151, 158, 162, 192, 202

Vitaller: 115

Vitini, José: 103

Wehrmacht: 68

Weindling, Michèle: 37n., 90n.

Weitz, Margaret Collins: 13n., 83n.

Weyler, Valeriano: 205

Wolf, Eric: 21, 22 y n.

Wrigley, Linda: 41n.
Yagüe Blanco, Juan: 92, 93, 110 y n.

Yalta: 41, 123

Yufera, Joaquín: 92

Yugoslavia: 38, 39, 247

Yusta, Mercedes: IX, X, 15n., 58n., 108n., 125n., 182n., 190n., 238n., 239n.

Zaera Monforte, Urbano: 222 y n.

Zapater, Carmen: 53

Zapatero: 156

Zapatero, grupo del: 119

Zaragoza: 9, 72, 76, 93, 112, 113, 115, $116,118,120,121,122 \mathrm{n} ., 123$, $125,127,133,144,145,148-150$, 157, 162, 194, 195, 201

Zaragoza (partido judicial): 224

Zaragoza (provincia): 17, 51, 116, 120, $148,194,201,210,216,224$

Zuera: 120 


\section{ÍNDICE}

PRÓLOGO (Carlos Forcadell) ………………………………....... VII

AGRADECIMIENTOS ………………………………...........

1. INTRODUCCIÓN: UN CRUCE DE CAMINOS ENTRE LA HISTORIA Y LA MEMORIA ........................................... 3

2. HABLAR DE RESISTENCIA EN LA ESPAÑA

DE POSGUERRA............................................................ 15

2.1. Formas de resistencia en la sociedad campesina................. 15

2.2. La resistencia europea contra el fascismo. La resistencia española en el marco europeo ............................................ 25

3. GESTACIÓN DE LA GUERRILLA ARAGONESA............... 45

3.1. La semilla del descontento: horizontes de conflictividad en Aragón en los años cuarenta ................................. 45

3.2. Al otro lado de la frontera: la contribución de los españoles a la Resistencia francesa y sus consecuencias para la lucha en el interior

3.2.1. La Resistencia francesa y la resistencia de los espa-

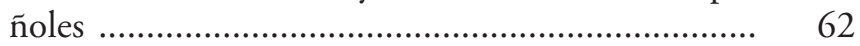

3.2.2. «Sólo se resisten a venir los que ayer no quisieron resistir». Las «invasiones» de 1944

4. DESARROLLO Y CARACTERÍSTICAS

DE LA GUERRILLA EN ARAGÓN........................................ 
4.1. La resistencia armada en Aragón: unidad y diversidad ...... 117 4.1.1. Consolidación de los núcleos guerrilleros (1944-1946)

4.1.2. "Franco es la guerra»: los años de apogeo (1947-1948) ......................................................... 148

4.1.3. Decadencia y fin de la guerrilla en Aragón (1949-1952) ........................................................... 180

4.2. El largo brazo de la represión ......................................... 203

4.3. Las relaciones entre la guerrilla y la sociedad rural aragonesa 214 4.3.1. Los posicionamientos del campesinado................. 214 4.3.2. Las mujeres, "guerrilleras del llano» ....................... 234

5. CONCLUSIONES............................................................... 247

FUENTES Y BIBLIOGRAFÍA..................................................... 253

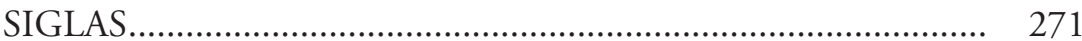


Este libro se terminó de imprimir en los talleres gráficos de la Sdad. Coop. de Artes Gráficas Librería General, de Zaragoza, el día 20 de marzo de 2003

Wo 
a presente investigación analiza

los origenes y el desarrollo de la guerrilla antifranquista en la región aragonesa entre 1939 y 1952, una guerrilla que marcó profundamente la vida del Aragón rural de posguerra y cuyo conocimiento es indispensable para comprender cómo se reorganizaron las relaciones sociales, politicas y económicas en los núcleos rurales aragoneses durante el primer franquismo. La guerrilla se convirtió en el telón de fondo, a la vez cotidiano y secreto, de la vida de miles de españoles durante los años cuarenta, un pretexto para la represión y el encuadramiento de cientos de campesinos, y al mismo tiempo una luz en el horizonte de quienes aún mantenían la esperanza en la vuelta de la República. En Aragón, la guerrilla se desarrolló al compás de los vaivenes de la situación internacional, entre el fin de la segunda guerra mundial y el comienzo de la guerra fria; también fue la manifestación local de los conflictos latentes que agitaban al campesinado aragonés desde antes de la guerra civil y que ésta no había resuelto. Integrando diferentes formas de hacer historia, como la historia comparada, la historia oral y la antropología histórica, el libro es al mismo tiempo una crónica de la guerrilla antifranquista aragonesa y un análisis de los problemas estructurales y de la vida cotidiana del Aragón rural en los años cuarenta.

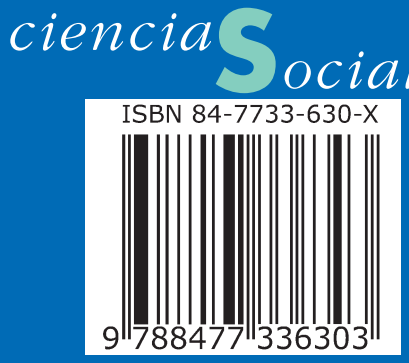

